
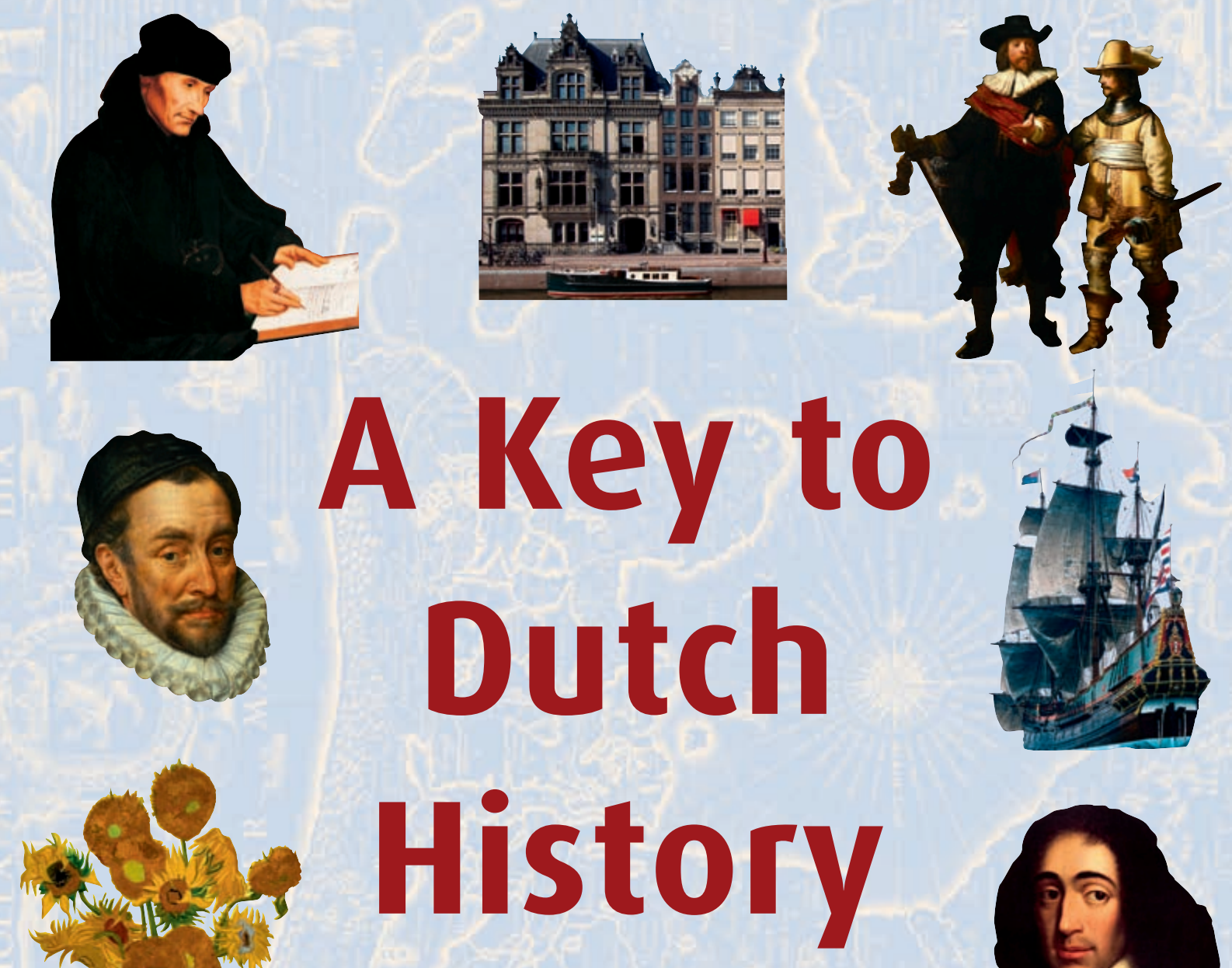

THE CULTURAL CANON OF THE NETHERLANDS
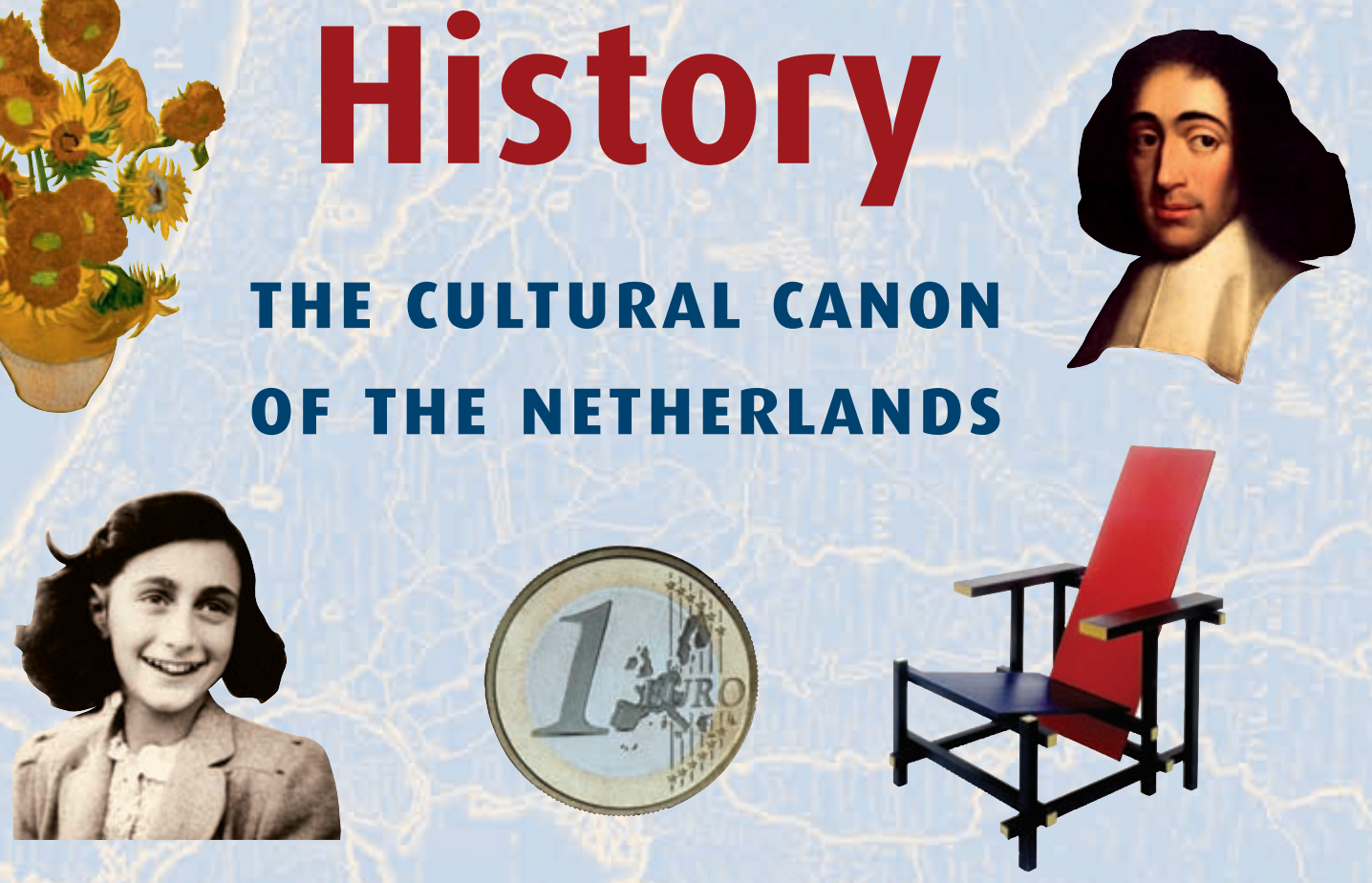

AMSTERDAM UNIVERSITY PRESS 
A Key to Dutch History 


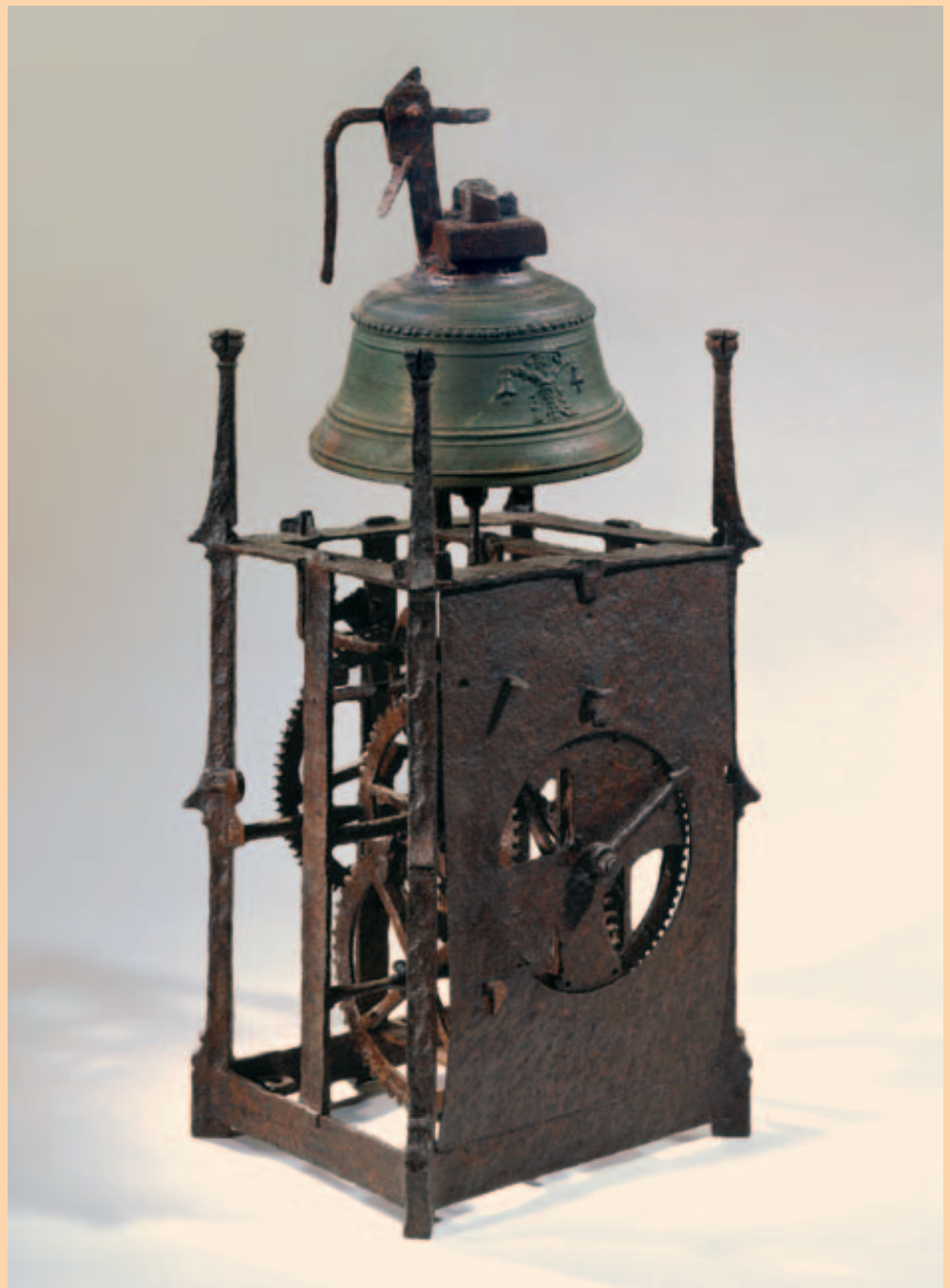

This iron clock was found on Nova Zembla. On 18 May 1596, two ships left Amsterdam for a reconnoitring expedition in the Arctic. The ship with expedition leader Willem Barentsz and captain Jacob van Heemskerck on board reached the island of Nova Zembla in the northernmost part of Russia and became icebound. The seventeen crew members were forced to spend the winter on the island. They did so in a shelter which they constructed using driftwood, referred to as the Behouden Huys [the Safe House]. It was ten months later before a return trip to civilisation could be undertaken by rowing boat. A lot of the crew's belongings remained behind on Nova Zembla including cutlery, clothing, weapons, books, tools and this clock. 


\section{A key to \\ Dutch History}

REPORT BY THE COMMITTEE FOR

THE DEVELOPMENT OF THE DUTCH CANON

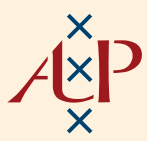

AMSTERDAM UNIVERSITY PRESS 


\section{(c) \\ C A N O N VAN \\ Nederland}

Publication of the Committee for the Development of the Dutch Canon

www.entoen.nu

(c) 2007 Frits van Oostrom, the Netherlands

ISBN 978-90-5356-498-1

NUR $688 / 840$

Published by Amsterdam University Press, the Netherlands

www.aup.nl

Design: Kok Korpershoek, Amsterdam, the Netherlands

Printing: Drukkerij Romer, Schiedam, the Netherlands

All rights reserved. Without limiting the rights under copyright reserved above, no part of this book may be reproduced, stored in or introduced into a retrieval system, or transmitted, in any form or by any means (electronic, mechanical, photocopying, recording or otherwise) without the written permission of both the copyright owner and the author of the book. 


\section{Contents}

11 Foreword to the English version

13 Foreword

15 Section A

16 Summary

CHAPTER 1

18 Canon - the pros and cons

Grounds, assignment, analysis, points of departure

$18 \quad 1.1$ Administrative grounds

$19 \quad 1.2$ The desire for a canon

$23 \quad 1.3$ The canon under fire

25 Intermezzo: Canons in Denmark

$27 \quad \mathbf{1 . 4}$ The power of the canon

CHAPIER 2

32 The canon outlined

Basis, content and form

$32 \quad 2.1$ Basis

34 Primary education sector

35 Aside on the local canon

36 Secondary education sector

$37 \quad 2.2$ Content 
39

39

40

41

44

46

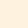

46

49

49

50

51

53

53

54

54

56

56

57

57

59

59

60

62

62

63

64

67

68

68

71

2.3 Form

Wall chart

(Virtual) treasure chest (for the time being)

Website

The canon as a "wiki"

CHAPIER 3

The canon in practice

Implementation in schools and society

3.1 The canon in the classroom

3.1.1 Primary education sector

History

Geography

Dutch language

The arts

Man and society

The local canon in primary schools

3.1.2 Secondary education sector

LOWER FORMS

History

Geography

Dutch language

Art \& culture

UPPER FORMS AND SECOND STAGE

Dutch language

Culture and the arts (CKV)

Social studies

3.1.3 Higher education

3.2 Teachers and their "baggage"

Refresher courses

3.3 Cultural institutions

Collaboration with schools

Cultural institutions and the canon 
75

75

76

77

\section{CHAPTER 4}

79 The canon in revision

Periodical maintenance of the canon

$79 \quad 4.1$ The ever-changing canon

$82 \quad 4.2$ Concrete procedures

\section{CHAPIER 5}

84 The canon in position

Recommendations and desiderata

(including: at what price the canon?)

86 Recommendations

86 With regard to the report

86

86

87

87

88

88

89

91
With regard to the design

The education sector

Provinces and municipalities

Cultural institutions

Market and society

With regard to the process
$89 \quad$ Closing remarks

1 Literature 


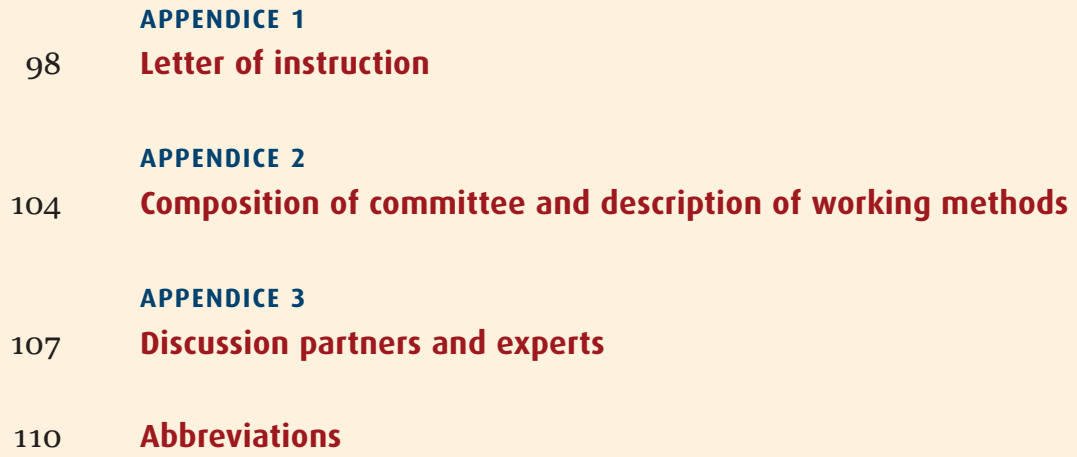


When we, as individuals, pick and mix cultural elements for ourselves, we do not do so indiscriminately, but according to our natures. Societies, too, must retain the ability to discriminate, to reject as well as to accept, to value some things above others, and to insist on the acceptance of those values by all their members. [...] If we are to build a plural society on the foundation of what unites us, we must face up to what divides. But the questions of core freedoms and primary loyalties can't be ducked. No society, no matter how tolerant, can expect to thrive if its citizens don't prize what their citizenship means - if, when asked what they stand for as Frenchmen, as Indians, as Britons, they cannot give clear replies.

Some etymologists speculate that the word 'canon' (as in 'canonical') is related to the Arabic word qanum, or law in the binding, legalistic sense of the word. But that is only one rather restrictive meaning. The other is a musical one, canon as a contrapuntal form employing numerous voices in usually strict imitation of each other, a form, in other words, expressing motion, playfulness, discovery, and, in the rhetorical sense, invention. Viewed this way, the canonical humanities, far from being a rigid tablet of fixed rules and monuments bullying us from the past [...] will always remain open to changing combinations of sense and signification.

EDWARD SAID ${ }^{2}$ 



\section{Foreword to the English version}

What basic knowledge of Dutch history and culture should we pass on to future generations of Dutch citizens? This was the difficult question facing us when the Minister of Education, Culture and Science asked us to design the canon of the Netherlands in mid-2005.

This is the result: a report in two sections. In section A, we explain the reasons and principles behind our design. Section B is the canon itself, in fifty windows. A wall chart and the www.entoen.nu website form part of our design.

In many ways, it has become a truly Dutch book. Mainly because it is about the Netherlands and is focused on the Netherlands - on the Dutch education system, and on mainly Dutch books and websites.

However, on closer examination you can see a third dimension: it has become a true Dutch canon because it was created in a typically Dutch way. It was not decreed by a central authority or a single lofty institution. Neither was it created by a majority vote in a referendum.

This canon was created by bringing together a number of specialists and allowing them to consult with one another and with a choice selection of interested individuals and stakeholders for a year. A website with a discussion forum allowed every Dutch citizen the opportunity to voice his or her opinion. The process brings to mind the way in which the Netherlands for centuries has succeeded in keeping its polders dry: collective craftsmanship.

The way in which this canon was created, therefore, could easily say as much about the Netherlands as do the fifty windows themselves.

6 January 2007

On behalf of the committee,

Frits van Oostrom,

Chair 



\section{Foreword}

Where there is no vision, the people perish.

PROVERBS 29:18

This is the report by the Committee for the Development of the Dutch Canon, which, as commissioned by the Minister of Education, Culture and Science, worked from 1 September 2005 to 1 September 2006 on (recommendations for) the historical and cultural canon of the Netherlands. In that year, there was a huge amount of interest in the committee's work. Evidently, a lot of people are keen to have a say in how the Netherlands deals with its culture and history. We explicitly wish to emphasise this very satisfying fact, now that this report is being published, partly because we sometimes had the impression that the process we had engaged had become associated all too frequently with complaints.

The canon of the Netherlands is neither a litany of complaints nor a monotonous chore. It is a positive creation which is intended to provide valuable support for modernity rather than being aimed against it. That was one of the reasons for our choice of frontispiece. In the clock of cultural history, the canon represents, to a certain extent, the big wheel which appears to be turning less dynamically than the faster, smaller wheel behind the little hand, but which still determines the basic speed. The permanent operation of the big wheel facilitates all the momentary effects of the other components.

Perhaps, in this election period, it is appropriate for us to say that the canon represents that which survives a great many cabinets and committees.

16 October 2006

On behalf of the committee,

Frits van Oostrom,

Chair 

Section A 


\section{Summary}

- as a story of the country we all live in

- the Netherlands not as a horizon, but as an observation post

- not as a vehicle for national pride, but rather a canon that evokes involvement

- not a mausoleum, but a living heritage

- a canon that is open rather than closed

- no lists, but windows

- modern technology not as a threat, but as an ally

- familiarisation with the canon as natural baggage

- not a final goal, but an inspiring foundation, to be laid in primary education

- to be installed first, in order to be able to put into perspective later

- not a new school subject, not a complete curriculum, not a new textbook

- chart - chest - website 
- mastery is proven only in limitation

- choices, but no straitjacket

- with substantial attention for the teachers "who must bring alive", 3 and how they are trained

- give the subject back to the teacher - and give the teacher back to the subject

- not static, but dynamic

- not a lecture, but a discussion

- with invitations to the cultural world, market and society

- the canon as cultural capital with invaluable yields

- daring to invest in general education and immaterial infrastructures

- a fund for the future

The canon not as a problem, but as an opportunity

3 Quote from Gerard Knuvelder (Van Duinkerken \& Knuvelder 1928, p. 10). 


\section{The canon - the pros and cons}

\section{Grounds, assignment, analysis, points of departure}

In former times [...] all children were [...] well educated, which is something they no longer are these days. The world was a much better place in those times.

THOMASIN VON ZERKLAERE, SHORTLY AFTER 1200

\subsection{Administrative grounds}

In January 2005, the Education Council published some recommendations entitled De stand van educatief Nederland [The State of Affairs in Dutch education]. In this report, the Council reflects on five years of Dutch education policy and establishes that - in addition to all the good things - there are four trouble areas. One of the most significant is a lack of "a focus on the 'canon' as an expression of our cultural identity". ${ }^{4}$ The Council placed the word canon in speech marks, because it is a general term. A lot could be said on this matter, but this is not the place to do so. In the context of our goal we can make do with the working definition used by the Council, namely "the valuable aspects of our culture and history which we wish to pass on via education to new generations".

This observation in relation to the canon was the reason why the Council argued that education should fulfil a socialisation task and that its social responsibility be strengthened. The integration problem observed by the Council played a clear role in this vision. Certainly given the large number of children of foreign origin, the Council regarded the proper teaching of Dutch history and culture at schools to be even more important. 
The Education Council's analysis and recommendation were generally well received. ${ }^{5}$ In the public arena, the report was welcomed with open arms by quite significant numbers of opinion leaders. This was, in itself, probably a reflection of the change in attitude as regards the canon. After all, in 1989, the committee that had dared to draw up an obligatory reading list of Dutch literary masterpieces for use at school, had been tarred and feathered. ${ }^{6}$ De stand van educatief Nederland, and more particularly the views expressed on the canon, struck a broad sympathetic chord in parliament as well. The Minister of Education, Culture and Science, to whom the Education Council had directed its report in the first instance, considered this sufficient grounds to adopt the main recommendations and to set up a Commissie Ontwikkeling Nederlandse Canon as of 1 September 2005. This committee was not made up of representatives from umbrella organisations or - as was originally the idea - of chairs from influential advisory bodies, but of eight individuals with a variety of expertise. ${ }^{7}$ The committee was given a year to produce a concrete draft for the content of the Dutch canon, plus a vision on how this could be implemented in the education system. In addition, the committee had to focus on the role of cultural institutions in the matter and submit a proposal on how the canon could be periodically re-evaluated in the future.

In the following chapters, this "canon committee" details its response to the above questions, and its views on a number of other issues. Before that, we wish to summarise the deeper and more substantive background to the canon concept - including the criticism that has been levelled against it and explain how our committee chose to respond.

\subsection{The desire for a canon}

The Education Council's recommendation was born out of the emphatic conviction that something is wrong with the knowledge today's young people

5 Apart from the link with Dutch identity, which was the focus of most of the criticism (see below for the reasons). Mainly positive responses came from, for example, Kleijn \& Pleij 2005, Van Empel 2005 and Kieskamp 2005. Hekster 2005, Klein 2005 and De Rooy in Duursma 2005a were more critical.

6 See CVEN 1991. There was also a sensitive substantive difference: see note 37.

7 The chairs were interviewed briefly by Duursma 2005. The letter of instruction and personal details of the committee members are included in Appendices 1 and 3 . 
have of Dutch history and culture. ${ }^{8}$ Such laments about the demise of general knowledge are, of course, nothing new. In his Entheticus maior from around 1150, the poet, philosopher, churchman and scholar John of Salisbury translated into Dutch by Jan van Laarhoven - derides the "innovators who are irritated by old friends; only that which generates pleasure or profit brings contentment:

If you love authors, refer to the classical writings, People everywhere call out, "Where is the old donkey off to? What is he doing here with his outdated ideas and actions? We, we are wise of our own accord!" 9

There is, therefore, reason enough to suppress any feelings of nostalgia. The fact is, things in the garden were not all rosy in times gone by either. For example, most members of parliament who took part in the controversial questionnaire organised by the Historisch Nieuwsblad in 1996 and, by doing so, exposed their historical ignorance ("William of Orange was murdered in sixteen-something near Dokkum" ${ }^{10}$ ) had attended school before the 1963 Secondary Education Act, that is in what are now considered to be the thorough years. Moreover, research in Europe and the United States shows that large numbers of young people elsewhere also left secondary education with an inadequate knowledge of their own country's history. ${ }^{11}$ The problem is, therefore, certainly not limited to the here and now.

Nevertheless, something now seems to be going wrong. In recent decades, Dutch education has undergone developments which are sure to have had an effect on knowledge of the canon. To name but a few:

8 Previously, a similar conviction had caused the De Wit 1998 committee to advocate the introduction of a canon into historical education. De Rooy 2001 - who had been commissioned to develop that canon - eventually limited his work to a "frame of reference" comprising ten periods. See also Wilschut 2004 and Wilschut 2005, p. 31-43.

9 Van Laarhoven 1987. Quote (slightly abbreviated) on p. 471-472 (with thanks to medio Latinist Onno Kneepkens). The reverse also occurs: in 1532, Rabelais had the old giant Gargantua write to his son Pantagruel (who was studying in Paris) that "by the grace of God, light and dignity are now being assigned once again to language and literature and I can see such an improvement that I would have trouble being admitted to the first year at primary school... me who at a mature age was rightly regarded as the greatest scholar of that century".

10 Rensman \& Bossmann 1996.

11 See for Europe Angvik \& Von Borries 1997, for the UK Henry 2004, and for the USA Kearl 1994. 
- The time reserved for historical-cultural teaching has decreased, both at schools and in the teacher-training courses. ${ }^{12}$ The consequence is that both students and young teachers are insufficiently equipped in this field.

- In general terms, less value is attached to the transfer of knowledge than skills training.

- As far as knowledge itself is concerned, general education is losing ground, and this process starts at an early stage. It is significant that the CITO [National Institute for Educational Measurement] test, which pupils take at the end of primary school, does focus a lot on the area of "knowledge of the world", but this does not then count for the determination of the famous CITO score which is used to indicate the type of education the pupil should be advised to attend next.

- All manner of subject-oriented developments have also played a role. In the case of Dutch language - at school and at university - the focus shifted from literature to linguistic competence. History teaching methods were also affected by changes which were not conducive to the canon, such as less of an accent on the classical (and class-based) narrative element and the fear of being branded elitist. In addition, a shift could be observed from primarily chronological to primarily thematic education, and the undeniable increase in focus on academia also reduced superficiality in favour of (selective) deepening. ${ }^{13}$ The inevitable disadvantage of this was that students educated in this way easily lost sight of the connection between the individual items and the overview. Like prototype trainee research assistants, they knew a great deal about a small number of subjects but sometimes had to admit to embarrassing gaps in their knowledge in areas which, to previous generations, were the actual mainstays of historical-cultural

A critical opinion on the part of a number of teachers on this decline can be found in the article entitled "Hoe belangrijk is onze geschiedenis eigenlijk?" in: Dagblad van het Noorden (8 March 2005).

13 The consequence was that pupils are confronted by terms such as "primary social connections" in the context of how families used to live. Such expressions come from the domain descriptions of the national history exam, but are channelled directly to the pupils (see for example the very pleasant site www.bronnenuitamsterdam.nl). For the canon and history education see, for example, Groot 2006. 
knowledge. This very significantly applies, for example, to knowledge of historical chronology which is often sorely lacking among many young people. 14

In this report we do not want to go overboard when it comes to providing examples of the need for a new canon. Many are enough to make you laugh and cry at the same time. Suffice to say that we do not need to have any illusions about the answers today's Dutch students would give if, for example, they were to be questioned about the dates and chronology of Charlemagne and Charles V.

We wish to reiterate, for the sake of complete clarity, that our committee has not carried out any research of its own into the state of the Dutch canon. In line with the ministerial assignment, we have adopted the point of departure that considerable improvements can be made. The committee has, in the meantime, by no means had to worry about having a bad conscience with regard to accepting this premise. Both the Education Council's diagnosis plus subsequent responses and the above analysis of developments in Dutch education make it more than plausible that there is a worryingly low level of knowledge of the canon.

On the other hand, many people believe that such knowledge is, in fact, very important these days. They see (knowledge of) the canon as a way of countering all kinds of internal and external disintegrative factors. In this context, Europe has for years been presented by certain people as an example of such a disastrous outside force. In the process of unification, the countries are said to be losing themselves and their individual cultures. In more recent times, the same sensationalist effect has been attributed to the way new

14 The important reports drawn up by the De Wit 1998 and De Rooy 2001 committees went against this current in a movement which has since gained in strength and from which the canon committee evidently also has its roots. For example, professors Bank and De Rooy published a piece in NRC Handelsblad entitled "Een canon van het Nederlandse verleden. Wat iedereen moét weten van de vaderlandse geschiedenis." [A canon of the Dutch past. What everyone must know about our country's history] (In the printed version - Bank, Van Es \& De Rooy 2005 the title reflected a typically Dutch aversion to coercion in that "must know" had been changed to "wants to know"). Other publications included those of Beliën 2005, Van der Horst 2005, Lendering 2005 and Palm 2005. Of course, the canon committee endorses such comments, including those of Kempers in 1999, and the Academische boekengids (edition 24, December 2000) which was devoted to the canon. 
Dutch citizens are dealt with. People are often heard to say that newcomers' naturalisation courses should include a, perhaps obligatory, large Dutch history and culture component. In such arguments, the canon serves as an integration resource with which to provide newcomers with a sorely-needed insight into (and a feeling for) the country in which they live, and as a means of establishing a link and of building bridges between them and native Dutch people. Collective terminology such as "newcomers" and "native Dutch" can, incidentally, be as unsavoury as they are inadequate. Such opinions are often accompanied by the insistence that the Netherlands must learn to reassess its identity and that, as regards the latter, it would not do any harm if Dutch people, who often tend to be contemptuous of their own culture, were to engage in more open displays of their love and pride for what this country has achieved over the centuries. In this context the canon becomes a guiding principle.

Comments like those above came thick and fast in response to De stand van educatie in Nederland, albeit in varying formulations. At the same time, such responses were also the reason for increased criticism of the canon.

\subsection{The canon under fire ${ }^{15}$}

Sceptics and opponents of a canon for the Netherlands pointed out that a national framing of cultural history can easily lead to distortion, anachronisms, narrow-mindedness and a desire for annexation. ${ }^{16}$ If, on top of this, such a canon is also cross-fertilised with national pride, it will have already caused an extensive falsification of history. The situation certainly does not get any better if the canon is presented as a mirror of our national identity which is, once again, such a questionable concept which is said to have evolved, wondrously enough, by means of intelligent design in the centuries during which the nation did not even exist. A national canon requires "hollandocentrism" and that, by definition, means exposure to misrepresentation. Lastly, the concept of a "canon" is certainly not above criticism. The idea that principles which are open to objectification might exist and provide the grounds for putting forward certain events, people and artefacts for special

15 This section includes elements taken from the volume by Maaike Meijer et al 1991.

16 See, for example, Ribbens 2004, Grever \& Ribbens 2005, Klein 2006, Stuurman 2006. There are also voices of dissent, for example Palm 2005, Pels 2005. 
status to then create the canon appears to be an illusion to more people than just fervent postmodernists and those of a politically-correct persuasion. Something like this will always be plagued by blind spots and sly mechanisms of exclusion as regards cultural minorities, women, all that is considered valuable in the so-called margins, right through to individual cases of flagrant misjudgements. In the nineteenth century, the colourful Reis van Sint Brandaan was denounced by all and sundry as "the greatest piece of trash that we have retained from the Middle Ages" (according to P. Leendertz jr.) ${ }^{17}$. However, since the pioneering work of Maartje Draak - who was also someone who came to the fore from the margins - it has been regarded as one of the most fascinating and richest texts in Middle Dutch literature. Whether the literary canon is that of Kloos, Knuvelder or Komrij, the variation reflected in their selection illustrates the greater influence of subjective preference than is usually assumed in the case of such authorities. ${ }^{18}$

On the other hand, as yet, few success stories can be reported from countries that have recently tried to implement a canon as an inter-subjective process overseen by groups of experts. In the United States, the introduction in 2003 of the "history standards" - a core curriculum defined by the federal government relating to American and world history - led to heated debates and heavy criticism. ${ }^{19}$ In Denmark a "Kulturkanon" was published in January 2006 and was followed, in June, by a "Historiekanon". The basis of support for the cultural canon as an instrument in education will become apparent once 175,000 copies of the accompanying book have been distributed to schools and related institutions. The first responses were rather moderate and have stressed, above all, the relative character of the choices made. The publication of the history canon in June generated a frank and sharp-worded response.

Incide

welcome), but is also something that can be forgotten in the application of their work. In that context The classic hundred (Harmon 1990) is more inter-subjective. This is a selection, from canonical miscellanies, of the one hundred most popular English poems which one then dared to label as "the greatest hits of English poetry" (with "The tiger" by William Blake occupying the top spot). The questionnaire compiled by the BBC was more democratic. It invited the British people to indicate what they regarded to be the one hundred most important books in English literature. First place went to Tolkien's trilogy The Lord of the Rings. See The big read, www.bbc.co.uk/arts/bigread.

19 See for example Draper 2003. 


\section{Canons in Denmark}

The Danish Kulturkanon consists of a selection of 108 works, twelve for each of the following nine disciplines: architecture, visual arts, trades and design, film, literature, classical music, popular music, theatre and youth culture. For each discipline a separate subcommittee, consisting of artists and experts, drew up the

criteria on which choices could be made. The objectives for the composition of a cultural canon including the "greatest

and most important works from Danish culture" were articulated in the introduction to the report as follows:

- to contribute to the cultural debate by presenting a yardstick for quality which will, of course, at the same time generate a welcome discussion of quality criteria;

- to specify what is good and what is worth preserving for posterity;

- to offer Danes an insight into Danish cultural history so that they can find out more about themselves;

- to provide points of reference for what is typically Danish in a globalising world;

- to strengthen society by identifying common historical baggage.

The committee chairman, Prof. Dr Jørn Lund (director of the Danish language and literature association who, in 2002, was also chairman of a committee for a literary canon), also emphasised the fact that Danish art and culture has, in many respects, international connections. A lot of what was selected for the cultural canon has been affected by those very influences. A focus on that which is Danish is not, therefore, synonymous with isolationism. The choices made within the various disciplines were the result of a range of different criteria which all have to do with the inherent qualities of the work, the importance of someone's 
total oeuvre, the significance of a certain artist, historical and geographical distribution, etc. This means that the 108 works do not jointly constitute a "summary" of Danish art and culture, but primarily a guideline on how to deal with the products of the various disciplines over the centuries (from the Sun Chariot which dates from around 1400 BC to the film Festen from 1998). Since August 2006, the Kulturkanon has been developed in more detail to include an interactive section on the website of the Ministry of Culture (kulturkanon.kum.dk).

Besides this cultural canon, the Minister for Education and Ecclesiastical Affairs, Bertel Haader, set up a committee in January 2006 "to strengthen the subject of history at the folkeskole". The reason was the government's intention, supported by parliament, to make knowledge of Christianity, history and social studies examination subjects at the end of primary education (folkeskole - nine classes). In June 2006, this same committee (chaired by historian Prof. Dr Knud Jespersen) issued a report on the organisational changes and core competences which the introduction of these changes would require as of 2008, plus a first draft of an obligatory history canon. This history canon consists of twenty-nine national and international "subjects" or rather key words, such as "Columbus", "the battle at Dybbøl in 1864 (the Second War of Schleswig)", "female suffrage", and " $9 / 11$ ". This canon generated a heated discussion in the Danish media. ${ }^{20}$ 
In short, the canon is conceptually vulnerable, ideologically questionable and, on the one hand, even suspect. It is, as a construction, a lot more fragile than the pretences suggest and certainly not guaranteed to be a success as a collective process. Given all these deficiencies, one would be forgiven for concluding that the supposed canon for the Netherlands ought not to be designed by a committee nor imposed on anyone.

Our committee regards this criticism as perfectly justified and worthy of consideration. It is also a salutary counterbalance for unrealistic expectations relating to the canon or even its abuse. However, the committee believes this should not lead to negativism. (If the situation had been different, the committee could not, of course, have accepted the assignment.) Put more positively, the committee believes firmly in the power of the canon. ${ }^{21}$

\subsection{The power of the canon}

Indeed, the canon does appear to be a poor choice as a basis for a presumed Dutch identity. Although it is logical that the canon will sometimes include phenomena which - not least in the eyes of foreigners - can be regarded as "typically Dutch" (for example, our highly developed corporate life, known in more informal terms as the "polder model"), it is not acceptable to see the canon and a country's identity as one and the same. Acquiring an insight into the canon is complex enough without hypothecating it with the equally ponderous and tenuous concept of national identity. By far the best approach would appear to be to disconnect the two concepts. ${ }^{22}$ The canon may perhaps mirror a country's collective memory, but never its identity. Incidentally, there would appear to be every good reason to rethink the whole concept of "national identity". It is now less valid than it ever has been, if indeed it ever was. In today's international, multicultural world it is a deceptive and even dangerous concept. ${ }^{23}$

This is much more in line with Doorman 2004, Zeeman 2002 and 2004 and Scheffer 2005. Cf. Davids 2005.

Cf. Said 2004, p. $24 \mathrm{ff}$ and p. 55. Even at an individual level, cultural identity is a tricky concept given that many have, in effect, multiple perceptions of what identity is: "a man will not just be gay, but gay and Catholic and Croatian". Cf. Sen 2006 and Appiah 2006 and the discussion of their cosmopolitan view in The New York Review of Books dated 22 June 2006 (which incidentally features Hugo Grotius as an inspiring law philosopher). 
Our committee is less dismissive, but still open-minded, about the association of the canon with naturalisation. Of course, there are reasonable grounds to argue that, after knowledge of the Dutch language, knowledge of the related history and culture can make a substantial contribution to accommodating newcomers to this country. ${ }^{24}$ Nevertheless, the committee does not regard this as the primary motive for compiling a canon. At any rate, the fragile knowledge of the canon is a problem for all Dutch people and certainly not specifically for immigrants. Of course, newcomers will adopt a different attitude to certain elements of the Dutch past and this can, on occasion, require teachers to be particularly sensitive. However, the difference appears to us to be one of progression rather than one of principle. The point is that this canon has to do with the country that we jointly inhabit. In that sense, the canon can certainly contribute to citizenship. Knowledge and understanding of how this country has developed, of the valuable things it has produced, and what it has meant in the world to date is a meaningful and enriching learning goal and provides society with a frame of reference that generates a yield whenever there is interaction and whenever Dutch people operate in the world. It is, therefore, the canon of both Boulahrouz and Beatrix.

Arguments for a canon based on identity and/or citizenship appear to be rooted mainly in concern for the current intellectual climate in the Netherlands. The committee would like to see a less defensive and more positive perception of the canon. Our focus is primarily on the value of the canon in itself. Not as the supposed solution to a special problem, but as the gilt-edged basic knowledge of Dutch cultural history which is so meaningful and welcome for future generations that learning about it at school requires no special justification. Of course, such comparisons always fall short. However, the committee regards knowledge of the canon as a no less self-evident fundamental learning goal than Euclidean geometry or the periodic table of elements. Even the winners of the quiz show "Twee voor twaalf" do not know everything and most people get by perfectly well with a lot less. We are convinced, however, that everyone should be familiar with essential points of reference. The fact that all of these

24 Just as, conversely, finding out in class about non-western cultures can be very educational for native Dutch children. More can be found on this matter in a number of proposals (see p. 51) and the body of thought behind the book by Nasser D. Khalili 2006, Tijdslijn van de islamitische kunst en architectuur [Timeline of Islamic art and architecture], whose English edition was distributed to 40,000 British schools thanks to a private initiative. 
can now be found on the Internet is not a valid reason to refuse to learn them like one used to do, by referring to an encyclopaedia, or to reject the multiplication tables because we now have calculators, or knowledge of topography because of the existence of route planners. In fact, it is only on the basis of a certain degree of fundamental knowledge that the Internet can make its riches known to users, without even counting the time that people today are not attached to a fibre optic cable. It is perhaps a rash claim after all the above palaver, but the committee means what it says, namely that getting to know the canon is a goal in itself.

In addition, the canon not only enables people to retain knowledge but also beauty. This explicitly applies to the musical dimension of the canon, as well as for a lot of the important historical and idealistic elements. There is, of course, a link - albeit not exactly one to one - between the canon and quality. It is often thanks to a special allure that people, places and events acquire a place in the canon. Likewise, it is no accident that the Colosseum and St Peter's in Rome are top attractions, nor that the opera house consistently plans repeat performances of Mozart's Don Giovanni. To connoisseurs, such choices may sometimes seem slightly obligatory. Even they like to hear things they recognise and may indeed be curious about how a new director interprets this classical piece. Thus, the canon also contains stories which are told over and over again, which are inexhaustible and which are rejuvenated again and again. ${ }^{25}$ They thank their durability, at least in part, to intrinsic qualities which are certainly worth finding out about and appreciating.

In this context, the example of Edward Said (1935-2003) is particularly interesting and inspiring. He himself had a Palestinian background and was educated in some of the best institutions in the West. He became world famous in academic circles due to his deconstruction of the Eurocentric canon in which he revealed how this was often an instrument of cultural imperialism. Nevertheless, towards the end of his life, he and his friend Daniël Barenboim performed Alle Menschen werden Brüder in the occupied territories of the Gaza Strip. He wrote a respectful introduction to Mimesis, Erich Auerbach's book on the literary canon, from Homer to Virginia Woolf, and argued passionately

25 A major example is Mous by Art Spiegelman that retells the story of the holocaust in the form of a strip cartoon about cats and mice. The story was awarded the Pulitzer prize in 1992, the highest literary distinction in America. 
for a revitalisation of classical virtues such as humanism and philology as a badly needed dam to stem the tide of modern coarseness. He professed a passionate belief "that we must in some perhaps almost instinctual way continue to hold on to a wonderfully stable order of great works of art whose sustaining power means a great deal to each of us in his or her own way". 26

Our committee is much more receptive to such positively composed arguments for the canon than the call for cultural "dyke-watching" or testy knowledge restoration. However, the canon will only be able to flourish in this affective form if it is a living canon and no wall of urns, if it is not imposed by dogmatic decree but is presented with enthusiasm, and accompanied by a candid invitation to look for more, in accordance with each person's personal talents and interest.

By far the most important vehicle for achieving this is education. This too has always been the case. The canon and school are like brother and sister. In his masterpiece Europäische Literatur und lateinisches Mittelalter, which was published in 1948 and which was conceived as a cultural antidote to the glorification by Nazism of Germanic characteristics, Ernst Robert Curtius showed just how much the entire culture of the Occident (to him this meant everyone from Homer to Goethe) was a united whole. According to Curtius, this was due to the canon of ancient culture which had been passed down in schools since the Middle Ages to (the elite of) each new generation. These days we would no longer present it in this form. However, the fact remains that education still has a crucial task to fulfil as regards the transfer of the canon - not least to children who are not familiarised with it in their home environments.

The fact that schools teach pupils about the canon does not imply anything like state education or cultural despotism, no more than the learning of Dutch topography or knowledge of nature do. It is nothing more or less than the historical-cultural translation of the assignment in which education and compulsory education are rooted, the only legal form of indoctrination known to any civilised country. 
Our committee is primarily interested in the canon, as offered at school, as an inspiring foundation. Foundation induces a restriction in size, at least in the first instance. The committee has made an explicit choice for this, and would prefer to see its draft extended in the long term rather than it running the risk of surfeiting education and entangling the canon in a surplus of material and good intentions. Inspiring implies a lot of attention not only for the content of the canon, but also for the (didactic) form. It is therefore essential that the canon is given an expressive, open and inviting character. As will hopefully become apparent, modern technology can play a formidable supportive role in this respect. Modern times do not, by any means, have to drown out the past, but can enable it to express itself in a way that has never been heard.

Lastly, and perhaps most importantly, we are interested in a canon for all Dutch people. Translated into the school environment, this means a canon which not just the teachers must know (including those who teach gymnastics), but also the school management team, the interim manager, the caretakers and the cleaners - and of course the parents and the parents' council, who will hopefully attach some importance to how their school deals with the canon. Such an explicit, not-exclusive-but-inclusive, canon requires an anchoring in the years of compulsory education. That is the reason why the canon committee has focused most on primary education and on the lower secondary school years. The following chapter contains details on the concrete canon we have drawn up. 


\section{CHAPTER 2}

\section{The canon outlined}

\section{Basis, content and form}

In der Beschränkung zeigt sich erst der Meister.

GOETHE (1749-1832)

\subsection{Basis}

The committee was asked to present a historical and a cultural canon of the Netherlands. That is a wide subject field that covers and transcends numerous subjects within the current education system. ${ }^{27}$ Nevertheless, the committee explicitly does not advocate a new, profiled school subject entitled "canon", albeit that something similar might, in some ways, be beneficial for the implementation of much that we support. However, the committee suspects that such a proposal would hamper the discussion with all kinds of extrinsic factors (and interests), and has no particular urge to talk the Dutch world of education, which in this respect is already overstocked, into new structural changes.

The canon committee therefore drafted a proposal which fits within the existing system of school types, subjects, proportions and attainment targets and which is, at the same time, sufficiently consistent and robust to cope with future changes. With this in mind, it is proposing an integrated canon with the quite substantial benefit that links and connections remain properly visible while any preliminary subdivision as regards subjects and aspects of subjects would, in effect, do injury to the principle of a canon.

27 In primary education, the broad field of the "historical and cultural canon" extends across a number of curriculum areas, namely "Dutch" (and in Friesland "the Frisian language" as well), "Knowing yourself and your world" (which includes the factual subjects of history and geography) and "Artistic awareness". See par. 3.1.2. for the situation in the lower secondary school years. 
As indicated, the canon proposal focuses on the school years which are structured in more or less the same way for all Dutch pupils, that is primary education and the lower secondary school years. ${ }^{28}$ In the committee's opinion, the inspiring basis that this canon offers will therefore have to be laid in a period of six or seven years. This means, more precisely, the senior classes at primary school (years 5 to 8 ) and the lower secondary school classes (at VMBO [pre-vocational secondary education] level, this means the first two years, and at HAVO/VWO [senior general secondary education/pre-university education] level the first three years). That does not mean that the canon has to be presented to children aged between seven and fourteen in the same way. From the point of view of psychological development, a significant shift takes place when children reach the age of around twelve. It is no coincidence that the transfer from primary to secondary education takes place at around the same age. When children are at primary school age, they generally benefit from concrete impressions and contents. As they grow older, they become more able to establish links and to think in abstract terms. As a result, their capacity to make judgements increases. ${ }^{29}$

On the grounds of these considerations, the committee would prefer the canon to be taught twice during a child's education; once at primary school level, and then during the lower secondary school years. The power of recognition and repetition may have an added value, provided justice is also done to the progression and enrichment which a pupil ought to experience by the later review of the material. This ambition is, incidentally, more or less in line with an established practice in Dutch education (whereby secondary education - certainly in the factual subjects - repeats a great deal of that which was also dealt with in primary education). This is an approach which, in our opinion, is compatible with that which a canon is and deserves in various learning phases. ${ }^{30}$

At the time, the De Wit 1998 committee decided on a similar focus. apply to all children to the same extent. This was one of the reasons for the differentiation between VMBO [pre-vocational secondary education]-HAVO [senior general secondary education]vwo [pre-university education].

30 Cf. the argument in favour of continuous learning lines ("Iongitudinal cohesion") and concentric treatment in, for example, De Wit 1998, De Rooy 2001 and Onderwijsraad \& Raad voor Cultuur 2006. 


\section{Primary education sector}

When compiling the canon for primary education - the foundation for everything - we took account of a number of limiting conditions and characteristics of this type of education.

- Make as concrete and as narrative choices as possible. Stories help children to give meaning to their experiences and the world around them. Stories have a motivating effect and help ensure that subject matter is retained. Prepare abstracts and contexts which have to be dealt with in secondary education with a concrete and appealing story. ${ }^{31}$ An in-depth study of the essence of the Enlightenment is too much for pupils in primary education, but the story of a simple wool worker who wanted to show his contemporaries, using a planetarium (which still exists today) in the ceiling of his living room in Friesland, that the earth would not perish as a result of a conjunction of planets, does open a window on an age and the spirit which was prevalent at the time.

- Create stepping stones through the delta of cultural history and provide children with handholds in time. It is not necessary, and is even undesirable, to immediately aim to achieve a fluid whole. Gaps are perfectly permissible as long as there is general cover and sufficient scope for an initial familiarisation period.

- Create a chronological order and realisation using clear timeframes. The fact that it may no longer be sensible for primary school pupils to learn lots of historical dates by heart, as used to be the case, must not mean that we no longer give young children the tool of chronology so that they can become familiar with it as an instrument which they can use for the rest of their lives. The canon and chronology can have a mutually strengthening effect during the process of becoming familiar with the events of the various centuries. ${ }^{32}$ As far as this is concerned, the canon committee fully agrees with the periods introduced by the De Rooy committee.

31 Further argumentation for narrative pedagogics in Bruner 1986, Egan 1988, The Haas 1999 and, specifically for the subject of history at primary school, Pols 2004, and particularly p. 13. See also the interdisciplinary cooperation project known as Verhaal Centraal 2006.

32 The fact that Dutch young people today seem to lack this knowledge and have no idea as to which century Erasmus or Napoleon lived in, is a much-heard complaint by society as a whole and, indeed, is as regrettable as it is unnecessary. The committee would like the canon to be incorporated into Dutch education in conjunction with clear measures to rectify this situation. Cf. Schroots and Langemeijer 2004 (who want to go even further). Cf. recommendation 4. 
- Make it as visual and tangible as possible. It is, of course, not true that only the newest generations of young people are visually oriented. One only has to think of the contribution made to our historical perception by the old school illustrations of Isings and Jetses. However, the influence of the image culture has been steadily increasing during recent decades. The fact that the supply and demand (and technical possibilities) which are accompanying this increase seem to be keeping pace for the time being is also beneficial to the canon. Never before have Dutch children been able to study the past so easily.

- Make the canon appealing and inviting. The success of even the most impressive subject at primary school still depends on the way in which it is presented. In this context it is particularly important to focus on the interplay of past and present and the current applications of the canon, as a didactic resource and also for idealistic reasons. After all, as we have already mentioned, our committee believes that only a living canon will be successful. That is also the reason for the title we chose, in which we have tried to combine the historical, the narrative and the world of today: entoen.nu ["and then now"].

- Search close to home. For the young child, the big wide world is just round the corner. For our canon this means that the focus in primary education lies all the more on stories about the Netherlands. The position of the Netherlands in the world will, of course, be dealt with and important international links referred to although not (yet) in too much detail.

\section{Aside on the local canon}

In this context, our committee would explicitly like to advocate local forms of the canon. The development of these was not part of our assignment which, after all, concerns "the story of the Netherlands". However, certainly in primary education, and for both psychological and practical reasons, there is a great deal to say in favour of translating the national canon into a local context. This would work well, for example, in the case of local stories about World War II and the occupation, for which eyewitnesses could be asked to contribute to the lessons (see recommendation 16). Other local items which could be used are: old local railway lines, industrial heritage, the canals in the children's own town and burial mounds as the local variant on megalithic tombs. ${ }^{33}$

33 A nice example is the education project entitled "Verhalen van veteranen" [Veterans' stories] (Greven 2005). 
In addition, "the canon of the region" deserves special attention, particularly in primary education. There are specific reasons for this which go beyond being simply a manifestation of the national context. Attention could, for example, be focused on phenomena such as the origin of place and street names, famous local people, local excursions, etc. This may involve "large" topics such as Couperus and The Hague School of painters, which could quite easily be taught to young children in The Hague despite such issues only being part of the curriculum at a later date elsewhere in the country. However, our committee also regards all local perceptions of history and culture as being of great value. For example in the form of antiquities rooms, memorial tablets, courtyards, churches, monuments, ancient trees and even finding out how the SPAR corner shop in the oldest area of Leiderdorp has recreated itself as a mini museum on shopkeeping and corn chandleries. In this context, 'local' is certainly not the same as 'provincial'. It is precisely from stories told by local people that a lot can be learned about the history of the Netherlands as a country of migration. Our committee would much prefer local canons for primary education to be drawn up for each Dutch municipality. An initiative like the one in Hoogeveen ought to be made available to a lot more children. ${ }^{34}$ (See also par. 3.2.1 (conclusion) and recommendation 7).

\section{Secondary education sector}

The above-mentioned characteristics obviously also apply to the treatment of the canon in the first years of secondary education. However, different accents ought to be placed on a number of points. Concrete and narrative forms can still serve perfectly well as a point of departure. However, in secondary education these "vantage points" can provide a wider view. The committee believes that, in comparison to primary education and according to what the class can cope with, progress can be made with regard to the following issues:

- an increasing, widening and deepening of the material;

- greater cohesion (a more flowing story without gaps);

- more attention on international dimensions and contexts;

- more attention on abstract issues and processes (feudalism, communism, church and state);

- more attention on political and economic history;

- more attention on the foreign cultural canon;

34 See Thomese 2005, which can also be consulted via www.cultuurenschoolhoogeveen.nl/ allesisandersommeheen.htm. 
- more attention on art for "more mature adolescents";

- more attention on marginal figures and groups (and with that, the relativity of the canon as well).

If desired or necessary, some differentiation can take place in secondary education according to school type. For example, Simon Stevin could offer a better basis than Joost van den Vondel in the technical subjects at VMBO [pre-vocational secondary education] level. (See also par. 3.2.2 and recommendation 8.)

\subsection{Content}

The canon in primary education is therefore the logical basis for the canon which the committee is proposing. It is a tableau of strictly selected, "giltedged", but not necessarily sunny subjects from Dutch cultural history. These have been selected from a range of what are in our estimation the most important, best, and for primary school the clearest, subjects that Dutch cultural history has to offer. It is a canon with a deliberately limited scope, whose core comprises fifty items. These are briefly presented (in chronological order) and placed within a general frame of reference in the separate section B of this report. No further details are provided here in this paragraph. However, we feel we should provide some clarification of the principle of limitation as such.

As already stated, our aim was to create a canon for all Dutch people. Such an objective might well cause cultural missionaries, to whose number we are incidentally pleased to belong, to adopt a realistic and controlled approach from the start, and certainly given the target group of young children. Our committee does not in any way regard as being a problem the fact that our canon does not contain any spectacular surprises for those who are, to any extent, familiar with Dutch cultural history. Our goal was not to astound well-informed people with our original choices. Perhaps this apparent modesty is precisely the most effective means of achieving future development, at school and elsewhere. After all, thanks to selection, optimal use can at least be made of the material, which is not the case in the event of uncontrolled proliferation of all the possible themes and subjects which would then cloud people's vision.

The committee feels that it is supported in this philosophy by a paradoxical fact, namely that all our fifty items feature in standard school books - albeit never together - and that the complaints relating to insufficient knowledge of the canon are a daily occurrence. In other words, the question 
is not so much whether the canon is being dealt with, but how. Moreover, the problem appears to be that the canon is insufficiently embedded in the schools, rather than that it is not being taught. Should we, at this juncture, return to Goethe's brilliant principle of the limitation (see the motto of the chapter), and dare to prune to create new growth? ${ }^{35}$ It appears as if Dutch education during recent decades has quite frequently been the unintentional victim of a monstrous alliance between too many goals, excessive subject matter, too many good intentions, inflated and top-heavy attainment targets, over-fanciful school and work books; and all this in a context of too little time, social problems by the cartload and, on balance, insufficiently equipped and supported teachers.

It is therefore for both substantive and didactic reasons that the committee has chosen a limited canon, at least in the first instance (see below). A third reason is perhaps slightly more pragmatic but still very much essential for the viability of our proposals. For the sake of acceptance of our "range of ideas" we prefer to present a draft that stimulates rather than a plethora. After all, there is plenty of time for further development, if desired. (Cf. recommendations 30 and 31.)

At the same time, the decision to limit makes it essential that the canon does not wither into a kind of emergency ration, but has an active stimulating effect. That is why the committee deliberately decided not to restrict the canon to a bundle of lists or top tens (the ten most important/best/ most beautiful/most spectacular...), however arresting and, in a certain sense, attractive such instruments can be in this day and age. The canon is, however, no shopping list. For something of this scope, such lists would - in the words of Annie Proulx - be a reductio ad absurdum. ${ }^{36}$

We therefore view the canon not as a survival kit, but as the proverbial hat stand with sufficient hooks on which to hang a life long of learning and experiencing. ${ }^{37}$ We therefore see "the fifty" not so much as fixed items but

35 It seems as if this is also a matter of much wider purport than just the canon (cf. the conclusion to this report). Development psychologist Greetje van der Werf (2006) recently argued in favour of a definition being drawn up of a core curriculum for all school types and curriculum areas.

36 "Lists, unless grocery shopping lists, are truly a reductio ad absurdum," according to Annie Proulx, quoted in a debate on cultural competitions. Source: www.triangle.com/books, 11 December 2005.

37 The specification of twelve books which everyone should have read, the result of an uncontrolled obsession, was probably the mistake which fooled Anbeek cs in 1989 (preliminary advice for CVEN 1991). 
more like beacons, or even better, as windows which, hopefully, do not restrict the gaze for new generations but offer a view of the rich story of the Netherlands in the world. The result is therefore - just as in the case of real windows - a balanced construction, part framed and part open. That makes specific demands on the form, the presentation and the didactics of this canon. However, once again, modern technology plays magnificently into our hands. The canon which we are presenting therefore also has the characteristics of a "cross media concept".

\subsection{Form}

\section{Wall chart}

An integrated canon deserves to have at least one target on which all the aims are grouped. To this end, the committee has had a chart designed which depicts the fifty windows on a timeline, and of which a prototype is being published together with this report. The function of the chart is certainly not only to act as a symbol and/or a catalyst or give everyone a warm feeling inside. Instead, its primary and foremost function is didactic, in allowing children to instil canonical images (and their sequence), and to provoke their curiosity and their imagination. It is more than six hundred years ago that Jan Matthijssen, town clerk in Brielle, argued in favour of painting the council chamber, where the vroede lieden [city fathers] spent so much time, with wise sayings and inspiring portraits. ${ }^{38}$ He realised that people's gazes and thoughts sometimes wandered during long council sessions and that high-minded wall decorations would serve the memory and inspire. Or, as Jan Matthijssen described it: aensien doet ghedencken [seeing makes one think]. Intense visual reminders at schools were recorded in later centuries, for example the school wall decorations by Isings, Jetses, the primer, maps, Mendeleyevs periodic table and Jac. P. Thijsse. ${ }^{39}$ In the visual culture of our own century there is all the

38 With thanks to Wim van Anrooij. Matthijssen's text is literally, "Die raetcamer sal binnen suverlic ghemaect wesen ende besait van poortraturen ende bescreven mit goeden ouden wyser leeren, dairmen verder wijsheit ende vroetscip uut verstaen sal moghen; want men pleech te segghen: aensien doet ghedencken". See Van Anrooij 2006, p. 8.

39 See Van Oostrom 1998 and Blokker, Blokker \& Blokker 2005 for a modern appreciation of that tradition. The affectionate memories of Kousbroek 1995 are also impressive. 
more reason to continue to draw from the potential of such resources. ${ }^{40}$ The canon chart is intended to be hung permanently on the walls of primary school classrooms, in any event as of the year in which history education starts. The idea is for it to function as a reminder which combines the attractiveness of Isings with the basic approach adopted by Mendeleyev. The canon windows will then be able to function as an inspired context which, in this case, will indeed be able to be more than the sum of the parts. The chart is intended to have a significant effect throughout the school year, as it hopefully becomes a more and more visible feature of the classroom and as it serves more and more as a point of reference during lessons. Currently, only simple posters have been made of the chart. However, the committee intends a more definitive version to become available which will fulfil additional didactic functions. In the first instance it would be good if the chart was available in a variety of formats, according to the space and the use that schools and teachers (and possible other parties) intend allocating to it. Moreover, it should be possible for teachers to show which windows have already been dealt with (and what the "window of the day" is). In this way, the chart will act for the class as a collective checklist and "scoreboard" of progress. It is perhaps not beyond the realms of possibility to imagine that, when the class moves to a different classroom after the summer holidays, the wall chart, adjusted to the place reached in the previous year, will function as a reminder of last year and make children curious as to what the new year has in store. ${ }^{41}$

\section{RECOMMENDATION 1 Have a high-quality chart produced (in various formats) and deliver it to schools and any other interested parties - Ministry of OCW [Education, Culture and Science]}

\section{A (virtual) treasure chest (for the time being)}

Besides being visible, the canon should also be a feature of primary education which is as tangible as possible. Our committee was struck by the experiences of a teacher who familiarised ten-year-old pupils with the Industrial Revolution

Whereby the committee is aware that around 2,500 blind or partially-sighted pupils in regular education are confronted more and more frequently by - particularly digital - reading material which is not accessible to them (information published by the WEC-Raad interest group, 13 July 2006). Spokesperson Henk Snetselaar advocates a statutory obligation for publishers to produce their teaching material in such a way that it is accessible to these pupils.

41 Some people will associate this with the windows on an Advent calendar. 
by means of a classroom demonstration of a miniature steam engine. Similarly, life during the occupation could be vividly demonstrated by circulating ration tickets around the classroom and the ID card of the teacher's grandmother, while the teacher - or even her grandmother herself (see recommendation 16) - tells the story of life during the war. Other possibilities include allowing children to write using a quill when teaching about the oldest known Dutch love poem Hebban olla vogala (and with a dip pen when studying the works of the writer Multatuli?), or being able to take a look and leaf through Blaeu's Atlas maior, of which copies are, these days, reasonably affordable.

The committee proposes that each school make a "treasure chest of the Netherlands" specially for this purpose, containing (replicas of) objects which make finding out about each window of the canon a more tangible experience. ${ }^{42}$ (If the chest is itself designed as a replica of the one Hugo Grotius used to store books in, that window will immediately have its own artefact.) At this stage, the committee has not delved much beyond the idea of a virtual treasure chest "filled" with initial suggestions for the objects which could be used for each canon window (see the B section of this report for more specific details).

\section{RECOMMENDATION 2 Develop a treasure chest with objects to accompany the windows - Ministry of $\mathrm{OCW}$}

\section{Website}

While a canon on a chart and in a treasure chest might give the impression of a closed system, digital media offer the much-needed way out between open and closed, freedom of choice and a straitjacket. Hyperlinks enable children to open up the landscape for which the canon is the all-important and recognisable façade. That is why the committee has developed a website, as an essential and integral part of its draft, not so much as a modern version of the business card or because something would be sine qua non to generating any interest at all among young generations (both students and young teachers!), but rather because of its significant intrinsic additional value. The web help us to navigate between the dangerous rocks of a rigid canon on the one hand and the vast open sea on the other.

42 Cf. the initiative of the "monuments chest" by a number of organisations including Erfgoed Actueel. 
Although the chart is the most eye-catching element, the committee believes that the website will, certainly in the long run (see recommendation 3), be much more representative of the essence of the canon in its current conception. The chart is the solid variant, the site the living. Moreover, the latter can contribute easily to maintaining and revising the canon (more details are included in chapter 4 ).

In the limited time that the committee had available, it designed a frame of reference and initial details for the site which can be viewed at www.entoen.nu. The website is to go live when this report is published and will hopefully soon start acting as a digital magnet. The fifty windows each have a "page" on the site which runs parallel with the presentation in the B section of this report. As in the case of the canon, we are not going to devote a great deal of time to its content here. However, the following is a short clarification of the chosen format.

The fifty windows each open with an iconic image. A deliberate choice has been made to use authentic material for the various icons. Of course, a historical drawing can be made of Floris $\mathrm{V}$, of whom no contemporary image has survived, like the one that Isings made. However, the window we want to open has been made evocative by choosing an image of one of the buildings of which Floris V was chief architect - in this case the Binnenhof [Dutch parliament square buildings]. Incidentally, the Muider Castle would, in this case, have been just as good a choice and the site duly recognises this. However, the committee's preferred icon is the Binnenhof, due to the direct links which can then be made to the way in which the Netherlands is governed today. At the same time, this gives content to our aim to create a living past as entoen.nu wants to evoke. It is in this spirit that each window on the site is given a Past and Present section, in which we present ways of enriching the historical perspective by means of a view into our modern world (and vice-versa, of course). The icon and title are followed by the main story behind the window which clarifies the chosen subject and describes the backgrounds and their significance.

This is followed by the Sub-topics feature which comprises four sections that guide users to the material and themes related to the window. First there are a number of themes for the primary education sector, chosen partly because they allow interesting stories to be told which relate to the subjects presented via the window. This is followed by more advanced themes for the secondary education sector, which present routes for each window along 
which the desired scope and depth can be sought in secondary education. Incidentally, there is still a great deal of work to be done here (cf. recommendation 8). However, before getting completely engrossed in this, the committee decided it would be sensible to wait for the responses to the main ideas on which our canon work is based. This section is followed by the above-mentioned Past and Present items and the Treasure Chest section which refers to objects that represent the window in a material sense. (As long as the chest is virtual, this section will, of course, be rather noncommittal.)

A final feature is referred to as References. Under the title Places to Go, suggestions are made for excursions to museums and other locations which are relevant to the window. (The committee regards this as very important; cf. recommendations 14 and 15.) The following section refers to Books for young people which are relevant to the context of the window. ${ }^{43}$ In the committee's opinion, books for young people are a valuable accompaniment to the canon and enable young people to empathise intensely with the past. The Netherlands also has a strong and still-living tradition of high-quality historical books for young people, which runs from Paddeltje by Joh. H. Been and Fabricius' Scheepsjongens van Bontekoe to Zeekoorts by Rebecca Noldus. A lot of these publications are directly relevant to the canon episodes and people from Dutch history. The committee would regard it as a missed opportunity if they were not to accompany the canon, via the website. In addition, good books for young people help to prepare them for "real" literature education at secondary education level (see par. 3.1.2) as shown, for example, by the transition from Oorlogswinter to De aanslag.

The Background literature section refers to literature which we believe is eminently suitable as a background to the windows and the educational elements they reveal. Lastly, there is a Websites section from which users are referred directly to important sites elsewhere on the web which help to provide a sharper and richer view from the windows.

The website enables our initially limited and lightweight canon to be expanded, and this protects it from what would be the greatest risk of limitation: it going downhill and becoming too narrow as regards its scope. Take, for example, the perhaps most obligatory choice of all the fifty,

43 Special thanks are due to Lia Reedijk of the Utrechtse Kinderboekhandel who supported the committee's search for relevant titles. 
namely Rembrandt, with the Night Watch as the icon. The intention at primary school level cannot, of course, by any means be to limit the study of our seventeenth century paintings to this one painter and this one painting. Instead, Rembrandt and the Night Watch act very explicitly as a window on the world beyond and make the site accessible in a very inviting way, for example to other Rembrandts, to the Rijksmuseum [national gallery] and the Rembrandthuis museum and to all manner of Rembrandt items which, particularly in 2006, have become so abundant. However, they can also provide a link to Vermeer, the Mauritshuis gallery, the artists Hals en Steen and - if teachers manage to go that far - also to the Dutch art of painting (and photography?) from later centuries. The site allows unparalleled maximisation of the canon's richness and its reach. Via the links, the fifty subjects chosen lead us on into a world of new subjects, perspectives and possibilities.

The form in which entoen.nu is to be launched means the site is primarily aimed at teachers who will hopefully want to start using the canon very soon. A major priority is to start expanding the content as soon as possible. This will allow the site to evolve into a resource for all users of the canon, that is interested parties from outside and all those involved in education, including pupils. If we gaze into the future, it is possible to imagine children using the chart of fifty as a touch screen on their table tops. As their teacher opens up the corresponding Internet connection, the children set off on their canon journey.

\section{RECOMMENDATION 3 Arrange for the entoen.nu website to be managed and developed - Ministry of $\mathrm{OCW}$}

\section{The canon as a "wiki"}

Lastly, a canon which is intended to be used by everyone must also belong to everyone. The committee believes this should be the case, above all for intrinsic reasons. Within the period of time given to us it was inconceivable that we would manage to develop the site in full. Even if we had been allocated enough time, our expertise and powers of imagination would have been insufficient for such a task, from the points of view of both content and didactics. That was the basis for the idea of giving the site a function with which new offshoots and references can be put forward for each window, and existing ones enriched. In the first instance we believe this to be a task for teachers who can share their best practices. However, it can also involve specialists, organisations, amateurs, students and enthusiasts. The idea of 
them being completely free to contribute, as in the case of the real Wikipedia, may perhaps be a little too wild for the Dutch canon. An editing phase for additions is built in to the process before the information appears on the web. However, we still have faith in the basic principle of "freely contributing". A lot of people are enthusiastic about (sharing) the canon and think it will be beneficial since someone's bright idea or experience is often useful to others. The canon is certainly very suitable for such a "camp fire" approach.

Moreover, the committee is aware of the symbolism that such an approach to the national canon could serve as an example for the country in question. After all, the (canon) history shows us that the Netherlands has often championed freedom of speech and supported the power of collective action. In that respect, the canon as a "wiki" is also very Dutch at meta level. However, the committee regards it as even more important to send out a signal other than that of the site's wiki function. This illustrates the fact that we do not regard the canon as a lecture, but as a discussion. 


\section{CHAPTER 3}

\section{The canon in practice}

\section{Implementation in schools and society}

Education is not filling a bucket, but lighting a fire.

CANONICAL QUOTE, ATTRIBUTED TO - AMONG OTHERS -

HERACLITUS, PLUTARCHUS AND YEATS

The implementation of the canon proposal requires a great deal of attention from the very outset. A cursory glance alone will not bring our concept to life. This canon is not some ornament to be hung on the wall and looked at; it will have to prove its value in a broad range of practical applications. The most important of these is its natural habitat: the education sector. It is this sector that we will be focusing on most in the following chapter, along with the question of how teacher-training institutes can best equip future teachers to teach the canon. ${ }^{44}$ We will then - in the form of suggestions for participation - focus on the broader circle of cultural institutions (including the public broadcasting sector). Finally, we will take a brief look - from an appropriate distance - at the potential for interaction with other parts of society, including the free market.

\subsection{The canon in the classroom}

Again, although the fifty windows are intended as a package that every pupil going through the Dutch education system should be familiar with, they do not in themselves form an elaborate curriculum or a separate subject. They are not intended to be restrictive or limiting, nor are they in any way

44 For this is surely part of the probleem: young people in the Netherlands have little knowledge of the canon due to the fact that their teachers have less of a background in this area. 
intended to usurp entire lessons in one or more subjects. However, if we want - the starting point for this entire effort, after all - Dutch schools to focus on the canon more effectively, it is the committee's view that these fifty windows - at a minimum - should be dealt with thoroughly.

Education has a triadic structure: it is the union between teacher, pupil and knowledge that takes place in the classroom. ${ }^{45}$ This report places a central focus on knowledge, with an open view to both the pupils and teachers. In the end, it is the classroom where the canon actually takes shape in the education sector. It is the committee's express wish to leave room for all possible variations. The fifty windows will have to be opened in all sorts of contexts and situations within the increasingly multifaceted education sector in the Netherlands. The most important factor in its success is the teacher, who must bring the canon to life for his or her pupils. This will require more than a wall chart, a website and a treasure chest. The committee is fully confident that teachers are best equipped to judge which form the triad should take when teaching the canon in their class(es). That is why we have consciously steered away from any guidelines regarding the order in which the windows should be dealt with, as well as any far-reaching didactics. If our plea is well received, it would be fair to expect the development of more and more materials and expertise that will allow this canon to flourish in our education system. We only need to point to the wiki function on the website, and the opportunities for publishers and refresher projects. (Chapter 5 contains some specific recommendations.)

\section{RECOMMENDATION 4 Support and stimulate initiatives to develop didactics (including stimulating assignments and testing) as part of the canon's design - Ministry of $\mathrm{OCW}$}

The committee would like to devote a few words to the projected timeframe. To keep silent about this issue would be to ignore what may be the most central issue in modern education: the battle for time. And although the canon is no curriculum, the fifty windows will have to be opened in primary and secondary education curricula. As regards primary education, the committee worked on the basis of the following starting point: an average of three teaching periods per window, to be divided over the four (in general) 
years of factual subject teaching (i.e. a total of 150 hours). The windows were also designed to function as "lookout posts", from which to explore broader issues, so there should be sufficient potential for linkage with other curricular material in order to justify this amount of hours.

As mentioned, the committee believes the lower forms of secondary education should focus on the repetition and expansion of knowledge, divided between the various subjects or areas of study. This repetition could, for example, be condensed into a brief crash course used in combination with a digital diagnostic test to establish the first-year pupil's active and passive knowledge. This crash course is used to refresh pupils' existing knowledge (short words, historical context/timeline, combining pictures with persons/events/developments). In the follow-up to the first two or three lower forms, teachers can then refer to the windows incidentally. Estimating the required amount of hours is much more complex here than in the case of primary schools; one hour per window would seem a reasonable average for a basic orientation. (Enthusiasts will undoubtedly feel this is too little, and the windows certainly have more to offer; however, in view of the practical situation this seems a reasonable estimate.)

One of the most important preconditions for success may well be the training of new teachers, and ensuring they are sufficiently familiar with the canon and its teaching. Teachers must be sufficiently grounded in the canon if they are to present the windows to their pupils in a gripping and stimulating manner. If this foundation is weak, the teacher (and thus the class) will be forced to cling on to a method developed by others, degrading study and workbooks to a collective lifebuoy. The canon, however, cannot remain afloat through third-party teaching materials alone; this is why the committee is so insistent that our teachers should have a solid basis of knowledge. Paragraph 3.2 focuses on this issue in more depth. This section is preceded by a tour d'horizon of the various types of schools involved, the subjects they teach with relevance to the canon, and suggestions for dealing with our design within their framework. These comments are merely intended as a guideline for effective use, and do not pertain to be exhaustive. 


\subsubsection{Primary education sector}

The canon proposed by the committee basically consists of fifty windows on the Netherlands, as featured on the wall chart. The committee would suggest that this wall chart be displayed permanently in a preferably prominent place in the classroom from - at least - primary year 5 (8-9-year-olds) onwards. We would also advocate that every primary school draw up - in consultation - a global schedule in order to divide the fifty windows over the various years of study. In our view, there is no need to deal with each subject in a strictly chronological order. We would also suggest leaving a certain amount of room to focus on current developments with links to certain windows. (A school might invite teachers with affinity for a specific topic to act as "guest teachers" in their colleagues' classes from time to time.) Excursions can also be included in the schedule.

In its brief to the committee, the Ministry specifically requested that we take into account the revised attainment targets for primary school children that came to replace the 1998 targets as from August 2006.46 We feel that our proposal is fully in line with these targets.

\section{History}

A large number of the fifty windows primarily fall under the domain of history, a subject that is regarded as one of the factual subjects and is currently part of the area of study known as "Knowing yourself and your world". Subjects such as megaliths, the sixteenth-century iconoclastic outbreak, Michiel de Ruyter and Anne Frank - to name but a few - are dealt with in the common teaching methods; the greater portion of the windows is part of the standard curriculum. ${ }^{47}$ This could lead one to conclude: "But we already do that," which is true to a certain extent. The committee is therefore not advocating an entirely different approach to history education. The wall chart and website, however, do offer an excellent opportunity to focus more intensively on some of the most important topics - the canon.

One question that keeps springing up is the relationship between the canon and the frame of reference defined by the De Rooy Committee. Due to the fact that the canon has a broader scope than history education alone - the subject to which the De Rooy committee was limited - the ten

46 See www.kerndoelen.kennisnet.nl.

47 The committee would like to take this opportunity to extend its gratitude to the educational publishers who either provided or made available for inspection their teaching methods. 
periods suggested by De Rooy were not explicitly included in the canon. However, the two are far from mutually exclusive; the windows can easily be fitted into the ten periods. ${ }^{48}$ What is more, the windows can actually offer an opening to help bring the main characteristics of the ten time periods to life in the classroom. Recent studies have shown that this poses somewhat of a problem for primary school pupils. ${ }^{49}$ An example: the story of William of Orange paints a comprehensive picture of the distinctive aspect "the Uprising and the birth of the Netherlands" (Time period of discoverers and reformers 1500-1600). There are more examples. The industrial revolution can be made manifest through windows such as the first railroad and child labour, the nineteenth century emancipation movements are embodied by Aletta Jacobs. In short: the windows offer a unique opportunity to provide pupils with a better "grounding" in the abstract framework of the time periods.

\section{Geography}

The canon contains a number of geographically-oriented windows that fall within the domain of geography, a subject that is regarded as one of the factual subjects and is currently part of the area of study known as "Knowing yourself and your world". Due to the fact that geographical subjects are generally taught in a thematic order, the inclusion of the geographical windows does require a certain amount of creativity. The 1953 flood, for example, can be dealt with in the context of the fight against water as featured in the teaching method, but it may prove more appropriate to teach this window on 1 February, or - for even more dramatic effect - just as a storm is swirling around the classroom and the news reports the closing of the Oosterschelde storm surge barrier and the Maasland water defences.

It should be pointed out that traditional geography themes offer sufficient starting points for education on the canon. Mineral deposits are dealt with on a regular basis (gas pocket). The same applies to the Dutch landscapes (polder landscape: Beemster; harbour landscape: Port of Rotterdam).

48 We feel we must state our objection to the name and dating of one of the ten time periods, namely the "Age of monks and knights", spanning from 500 to 1000. This is a (previously identified, but never corrected) flaw in the - otherwise excellent - design by the De Rooy Committee. There were no knights in Europe prior to the year 1000. Medieval Studies places the genesis of knighthood somewhere during the eleventh century. In an effort to spare coming generations confusion in this area, our committee has taken the liberty of calling for rectification, through amendment of either the periodisation (500-1200?) or the designation. See the study by Wagenaar \& Van der Schoot 2004, p. 110-116, and Pols 2004a, p. 15. 
Focusing on the history of cartography as well as old maps and atlases (the Blaeu atlas) allows the teacher to transcend instrumental topography and instil the pupils with a greater love of and sense for maps. (We can identify a clear parallel with the role of the Hebban olla vogala window in language teaching; see hereafter.)

\section{Dutch language}

Primary education devotes a great deal of time to language teaching, which we can only applaud. Helping pupils gain a good command of the Dutch language deserves the highest priority. 50 At the same time, it is also good to impress upon young people that language is more than spelling, grammar and receptive reading alone. This is why the committee would like to make a plea - in the absence of a De Rooy committee on the subject of Dutch - for a bit more focus on language-based games and general language studies in order to help our children increase their skills and become more sensitive to language in general. ${ }^{51}$ Viewed from the perspective of the canon, it is also important that we realise just how much the history of the Netherlands is interlinked with the Dutch language. This was also at the basis of our decision to opt for the Hebban olla vogala window (and the windows dealing with the Authorised Dutch Version of the Bible, Multatuli and Annie M.G. Schmidt). Getting children to write the sentence Hebban olla vogala... on the blackboard and asking whether they know what this means offers a good starting point for delving into such issues. Written Dutch is a thousand years old! (And was once written with a quill, which can then be produced from the chest.) Creative teachers can use a plethora of methods to get pupils to "play with language", especially in combination with the mother tongues of new Dutch nationals. The comparison between various languages ('What would you call that in...?') provides all pupils with insight into the workings of language and offers a beneficial "side effect" for pupils of non-Dutch origins, namely the realisation that they have a skill that is special and (presently) unattainable for Dutch children.

There are many ways of delving into the subject of "language" (etymology, possibly in relation to the pupils' own first and last names,

50 We would like to refer to the plea (a notion we strongly support) regarding the importance of language in every subject by Van Beek \& Verhallen 2004.

51 A (reading) book for children of age 10 and up, written and illustrated with infectious enthusiasm: Woarom een buitenboordmotor eenzaom is... (Van Leeuwen 2004). 
names of towns and cities; proverbs (the Breughel painting!) 52 in a playful manner; ask grandmother, uncles and brothers about the Dutch dialect from their birthplace, old words their families used to use; listen to dialects from Friesland, Zeeland, the polder areas, Limburg, etc. Focusing on the rhyming style used by Annie M.G. Schmidt can help instil a very special sense of enjoyment and insight in children. Our committee believes that a greater focus in schools on these aspects of language would provide an extremely constructive impetus, generating more positive energy for both the Netherlands itself and the Dutch language than any nitpicking over the official spelling.

Obviously, Dutch education at primary school level largely consists of reading (out loud) education. The reading of Saïdjah and Adinda during the Max Havelaar window is - apart from other, content-based values - a ready opportunity to introduce children to the "magic of words" as the best possible preparation for more advanced literature education in secondary school. 53 Each of the windows was designed in an effort to bridge the gap between the canon and children's books (and films). An initial inventory, which will require regular updates, is featured on the website. If these books are available in the school library, they can be utilised both individually and in class. We should point out that the committee is concerned about the state of school libraries in the Dutch primary education sector. Public libraries go to considerable effort to support literary education; in an unfortunate side effect, many schools feel this discharges them from the responsibility of undertaking anything. Many school libraries have suffered as a result, a development worsened further by tighter budgets. Although we did not conduct any additional research in this area, the signs are not good, ${ }^{54}$ despite the fact that having enough good books close at hand - no disrespect intended to all public libraries at cycling distance and library buses - can still mean so much to children.

\section{RECOMmEndation 5 Assess the condition of school libraries and provide support if necessary - Ministry of $\mathrm{OCW}$}

52 Please refer to the wonderful educational tool featured at www.literatuurgeschiedenis.nl.

53 Our thanks go out to Theo Witte.

54 0ne of the saddest incidents we came across was a primary school that felt compelled to hive off its core library, as it had not been brought up to date with the latest spelling rules and had no funds for a new one. 


\section{The Arts}

According to the attainment targets, the area of study known as "orientation in the arts" is partly aimed at obtaining "some knowledge of and appreciation for aspects of cultural heritage". 55 The canon offers a sheer endless amount of starting points to this end. Obviously, the relationship between the canon and the arts is highlighted in the windows on the great painters and De Stijl, with all the vistas they contain. (Unfortunately, the committee was not able to afford Music and the Performing arts such a prominent position due to its strict selection procedures; we should point out that the website does contain numerous other references to music. However, we are saddened by the omission of an art form at which the Netherlands has excelled for decades: ballet. If only for this reason, please read Recommendation 6 .) The canon also contains a number of windows that offer a direct view of some of the most vital cultural heritage in the Netherlands: megaliths, the Ridderzaal [Hall of Knights], the Amsterdam canal ring, the Blaeu Atlas and country mansions, as well as the various churches built both before and after the sixteenth century iconoclasts.

\section{ReCOMmEndation 6 Assess how creative subjects such as Culture and the Arts (CKV) can be anchored even more firmly in the design, in terms of both content and didactics - Ministry of $0 \mathrm{CW}$}

\section{Man and society}

According to attainment target 38, pupils must be taught about "the essentials of the various religions that play an important role in Dutch multicultural society". Religion, and - as a logical consequence - especially the Christian religion, makes up an important theme in the story of the Netherlands and - consequently - the Dutch canon. The windows on Willibrord, the Beeldenstorm [sixteenth century iconoclastic outbreak], the Statenbijbel [Authorised Dutch Version of the Bible] and Diversity in the Netherlands can be used as starting points in dealing with the influence of religion on culture in the broadest sense of the word, and the constantly developing tradition of religious freedom.

55 Attainment target 56 from the Voorstel herziene kerndoelen basisonderwijs. This orientation should start as early as possible, according to the thesis Kunsteducatie met kleuters by Gabrielle Struijk (Hogeschool InHolland Rijswijk, 2006). The SLO [National Institute for Curriculum Development] is also working to develop curricula for education in the arts in the first years of primary education. 
Other windows, such as Erasmus and Spinoza, can be used to accentuate these themes further.

\section{The local canon in primary schools}

As we explained in the previous chapter, we feel that primary school teachers should deal with historical events in the most concrete and expressive way possible in order to help bring the past to life. This is why the committee would again like to voice its strong support for a local canon as a parallel project. It is essential, after all, that the national canon never obscures local cultural heritage. Over the past few years, a number of appealing initiatives have been developed in this area which we feel are deserving of further support. 56 In accordance with the idea of the fifty windows on the story of the Netherlands, primary schools could work in concordance with their municipalities (especially the archive and the Archaeological Department) and local experts to develop a local canon - which could also be illustrated by means of a map and/or website - of important facts, people and locations from the area. ${ }^{57}$

\section{RECOMMENDATION 7 Local canon initiatives in collaboration with educational and heritage institutions at the local level - Erfgoed actueel and VNG}

\subsubsection{Secondary Education sector}

One significant advantage of a canon for the primary education sector is that secondary school teachers will be able to build on an existing level of basic knowledge. Such a common frame of reference offers great didactic advantages in comparison with the vague prior knowledge of today's average transition class. The challenge for secondary school teachers will be to build on this basic knowledge, partly by revisiting the subjects - repetition and recognition are fertile didactic principles after all - and partly as an expansion of the fifty

56 See for instance the sites www.datbewarenwe.nl (heritage site for the primary education sector), the wonderful example www.drentsarchief.nl and www.monumentenzorg.nl, initiator of a "monuments treasure chest" for the first years of secondary education that can be rented from the provincial heritage associations.

57 In a later stage, the website entoen.nu could be supplemented with a blank map. Individual schools could then access this map by means of a login code, and fill it in with local and regional windows. 
windows. As we mentioned before, the committee suggests that this expansion should be guided by the principles of greater congruence (from stepping stones to cohesive storyline); a more international perspective (from the Netherlands in the world to Europe and the world); a greater focus on abstractions and processes; and a greater focus on individuals and groups in the shadow of the canon.

As of 2006, schools will be allowed to let go of the way in which subjects are structured in the lower forms of secondary education. The law merely prescribes the attainment targets, while schools are free to determine how these are then made concrete in educational programmes (subjects, areas of study, projects, etc.). In order to allow schools the leeway to set out their educational programmes as they see fit, these attainment targets were consciously formulated in broad, general terms. As of yet, it is unclear how these developments will play out, but it seems as though many HAVO and VWO schools are sticking with their existing structures, while many VMBO schools are adopting cross-curricular areas of study.

These changes may have both positive and negative effects with regards to the canon. Teachers that are not accustomed to thinking in terms of the "parcelling out of subjects" will be more inclined to adopt a cross-curricular canon, that transcends individual subjects. Under the new framework, the proposed fifty windows would correspond with the following areas of study: Dutch language, "man and society" (containing the subjects history and geography, as well as elements of social studies, ideologies and general economics) and "art and culture" (containing elements from the disciplines of music, dance, drama, handicrafts, drawing, textile arts and audiovisual education). In order to ensure that the canon does not become too fragmented and/or become so much of a "common property" that it no longer belongs to anyone, it would be advisable to appoint a group of teachers within the school as special custodians (cf. Recommendation 28).

The committee is concerned with regard to the purely thematic structure of many new educational methods designed for the areas of study mentioned above. "Man and society", for example, is taught by means of themes such as "my neighbourhood", "living together", and "rich and poor". No matter how prudent this choice of subjects is, structuring the curriculum along entirely thematic lines will make it difficult for pupils to gain a sense of order, oversight and coherence with regard to their knowledge of the history and culture of the Netherlands in the world. Knowledge of the chronology of events and geographical perspective will suffer most, which leads us back to 
the complaints that led to the establishment of the canon committee. Yet another reason, in other words, to ensure the (wall chart with the) fifty windows remain an integral part of our secondary education systems.

Due to the fact that many schools are set to maintain the existing structure in the lower forms of secondary education and the current system will definitely continue in the upper forms, we have formulated a number of additional considerations and suggestions with regard to the canon below, divided over the two stages of secondary education and the relevant subjects.

\section{LOWER FORMS}

\section{History}

As we pointed out in Chapter 1, history teaching is seeing a shift towards more chronologically anchored knowledge and less ordering along thematic lines. The accumulation of orientational knowledge has (once again) become an important objective. This is not a return to soulless cramming, but the revaluation of an intelligent form of acquiring knowledge that also requires historical skills. ${ }^{58}$ Naturally, the fifty windows can play an important role in building up such orientational knowledge. Assuming that primary school pupils will have become sufficiently familiar with the fifty as such, teachers in the lower forms of secondary education can then focus on building on this knowledge. History lessons in secondary education are generally taught from a European perspective (with strong Dutch accents), with an occasional foray into other continents. The fifty windows on the Dutch story will only require a limited amount of the available teaching periods. The committee does not advocate introducing a stronger national accent in history education. It does, however, suggest that cross-references be made with developments across Europe and the world from the starting point of the (partly already existing) knowledge of fifty core elements of Dutch history and culture. This will allow pupils to expand and add to their knowledge in a step-by-step manner.

Suggestions to this end can be found following the windows in the B-section. Also see our special comments on the desirability of designing - in addition to this Dutch version - an international canon in Chapter 4 and Recommendation 27. 
A suggestion: awaiting the actual design of an international canon, a nice project for secondary school classes or even entire schools (lower or upper forms, on an either subject-specific or cross-curricular basis) would be to design a map with fifty windows on European and/or world history!

\section{Geography}

With regard to geography, the abstract new attainment targets for the lower forms specify that pupils must build up a "geographical world-view". With regard to traditional school subjects, this intention is taking the shape of a focus on themes and areas on various geographical scales, ranging from global to local. Naturally, the Netherlands is one of the most obvious scale measures, offering a wide range of options for repetition, in-depth focus and contextualisation of the canon windows.

Lessons on the Netherlands generally deal with subjects such as: city and countryside, economic core regions, water issues, nature and the environment, Dutch landscapes, population geography, relations with Europe. The links to elements from the canon are evident: the ring of canals in Amsterdam, the Port of Rotterdam, the great flood, the gas deposits, the Beemster polder, diversity in the Netherlands, Europe. From a geography perspective, it would seem obvious to create links with other scale levels - an example would be the Port of Rotterdam in the perspective of global transport flows - and make comparisons with areas in other parts of the world - our modest influx of immigrants compared with the enormous regional refugee movements in conflict regions. Collaboration between history and geography create additional possibilities to focus on the canon in-depth: examples include the geography of the Netherlands in the industrial age or the geography of the colonial world.

Map and atlas reading skills, regarded as highly important in the lower forms, are often taught along instrumental lines: the main focus is on learning to read, analyse and interpret present-day (atlas) maps. (A memory of) the window with the Blaeu Atlas will also help stimulate "geographical awareness" at a meta-level.

\section{Dutch language}

Our plea for more language studies, linguistic sociology and language-based games at primary schools also extends to mother-tongue education in the secondary education system. This has increasingly shifted towards the teaching of language skills over the past few years, practised mainly by means of 
exercises based on matter-of-fact texts (both oral and written). Reflection and artistic notions have taken a backseat, while it seems likely that precisely these aspects can contribute significantly to the accumulation of these language skills. In the view of the committee, the same applies to literature, which has an undisputable formative value in terms of pupils' language skills. Obviously, literature education also goes right to the heart of the canon. At primary school level, we felt the windows need not look further than the unique triad Hebban olla vogala - Multatuli - Annie M.G. Schmidt; the literary canon must then be further expanded upon in secondary education. There is a reasonable amount of consensus as to the exact contents of this canon;59 the real problem is the didactic methods used to impart it upon today's young children. Wouldn't a seventeen-year-old in this day and age find Joe Speedboat more relevant than Max Havelaar? The committee is not prone to any rearguard battles (which are, incidentally, easily decided with pupils simply downloading book reports from the Internet), but would nevertheless like to see serious efforts being made to preserve the authors and texts that have traditionally been regarded as canonical. We will be making a number of comments with regard to this issue in subsequent sections dealing with the upper forms of secondary education, which includes the majority of these lessons as well as a separate exam on the subject of literature.

As a prelude, the lower forms of secondary education could deal with good children's books, and introduce pupils to the most important Dutch poetry 60 and various anthologies, introductions and texts developed especially for schools. (Why haven't we seen a modern-day version of the old illustrated Classics, containing classic stories from around the world? ${ }^{61}$ The success of the Tekst in context series - the most popular of which are the "canonical" instalments Karel en Elegast and Reinaert de vos - prove that the possibilities in this area are greater than is often assumed, if one is willing to make the effort. (The same and more is undoubtedly proven on a daily basis across the country, by enthusiastic, creative teachers who inspire their classes.

59 Please refer to the unequivocal results of the De Nederlandse klassieken anno 2002 survey, held amongst members of the Maatschappij der Nederlandse letterkunde, which can be found at www.dbnl.org.

60 In anthologies such as Domweg gelukkig in de Dapperstraat (Aarts en Van Etten 1990).

61 The committee is aware that cartoon books could be a powerful medium in this regard. Several users responding through the committee website indicated that they had gained most of their historical overview from the series Von nul tot nu. In the past few years, Dick Matena has created cartoon versions of Gerard Reve's De avonden and Jan Wolkers' Kort Amerikaans. 
The wiki function in the canon site leaves room for users to share such success stories.) ${ }^{62}$ The future of Max Havelaar may well lie in the teaching of Saïdjah en Adinda at primary schools, followed by a short lesson according to the Tekst in context formula. Linkage to new media also offers perspectives in this regard.

\section{Art \& culture}

The attainment targets for the new lower forms now include an area of study known as art \& culture, an amalgamation of drawing, handicrafts and music. A solid cultural foundation can then be laid on this basis. The formulation of the attainment targets is very cautious. The committee recommends that attainment target 50 ("The pupil learns to look at art, listen to music and watch and listen to theatre, dance and film on the basis of background information and prior knowledge") be implemented in a robust manner. Though pupils will naturally benefit greatly from the sense of participation (either through active participation or as a visitor), this does not mean knowledge should be taboo.

\section{UPPER FORMS AND SECOND STAGE}

After the lower forms, the secondary education system becomes extremely differentiated. In view of the reasons outlined in Chapter 1, the committee feels its responsibility with regard to the specified target ends here. This is all the more justifiable in view of the major reshuffle currently underway in the landscape of educational subjects, and the pending reports from the Veldhuis subject cluster committees in 2007. (We now know from informal consultations with these committees that there is no danger of any major discrepancies between those proposals and this report.) Nevertheless, our committee would like to offer some points for consideration with regard to the canon in the context of the Second Stage. These are points that arose in the process of gathering our thoughts, and cannot purport to be in any way comprehensive. In the upper forms of VMBO, HAVO and VWO, subjects such as geography and history are either elective subjects or mandatory for pupils with a specific subject cluster. These subjects offer plenty of opportunities to build on the knowledge of the fifty windows accumulated during the first phase. However, in view of the fact that some pupils will not have access to these subjects, we 
feel it would be wise to leave it at this observation and make a few comments with regard to the three subjects that are mandatory for all pupils: Dutch language (literature in particular), culture and the arts, and social studies.

\section{RECOMMENDATION 8 Further reflection on the place of the canon in the upper forms - Ministry of $\mathrm{OCW}$}

\section{Dutch language}

The VMBO study programme syllabus for Dutch includes "fiction-education", focusing on genres such as poetry, short stories, (children's) novels, comics, television series and films. The possibility of choosing for canon-related fiction would seem obvious in this regard. For an example, see the Rijksmuseum publication from 2006: Gedichten over Rembrandt [Poems on Rembrandt], the novel by Theun de Vries and many children's books on Rembrandt, as well as the current musical.

Literature makes its entrance in the form of a subject with an (final) examination grade during the Second Stage of HAVO-VWO. ${ }^{63}$ This means a significant part of the traditional canon must be dealt with during this period. This is not a bad thing in itself, as a great deal of canonical literature requires a certain amount of maturity in the reader. However, the canon committee would suggest that the lower forms of secondary education and even primary education provide more of an introduction to the appearance of "real" literature later on; see our suggestions to this end in the previous section. Our committee would also suggest that - as is already the case at certain schools - the required reading list for Second Stage literature education which specifies at least eight books for HAVO pupils and at least twelve for VWO pupils, at least three of which must be from before 1880 - should be bound to certain clauses. This will help guarantee a certain share of canonical works/authors, without predetermining the list to an unacceptable degree. One option would be to require that pupils choose at least four books from a predetermined - and regularly updated - list of canonical authors from the period between 1880 and the present (such as W.F. Hermans, Reve, Mulisch, Claus, Haasse; this could then be expanded for VWO pupils to include the period before 1880 with a selection from works such as

63 However, the separate grade for Literature Studies is in danger of being abolished, according to the 2007 proposal of alteration. Schools can decide that the grade should be "given back" to language subjects such as Dutch, English, etc. 
Reinaert, Muiderkring, Vondel and Multatuli. The Digital Library of Dutch Literature (dbnl) could develop a special domain to this end - "the canon in Dutch literature").64

\section{Recommendation 9 Develop digital domain "the canon in Dutch literature" - Digital Library of Dutch Literature}

We feel a basic active knowledge of the main developments in literary history should be required of every pupil: at a minimum, VWO pupils should be familiar with the names and profiles of the rederijkers (rhetoricians), Huygens, Potgieter and the Tachtigers. We would also like to point out that the tapestry of the canon could be interwoven more intricately by means of literature. Naturally, fine literature is interlinked with World War II in countless ways; however, other windows could also be enriched through works such as Oeroeg, Bezonken rood, Indische duinen, or - for the more adventurous De Vuuraanbidders, Bloem's essay on the Panorama Mesdag and almost all works by Thomas Rosenboom.

It should be pointed out that quite a few of those teaching literature, including those with a grade one teaching qualification [all levels of secondary education], are ill equipped for the task. This is hardly surprising in view of the drastic cuts in university reading lists since the introduction of the Two Tier Structure in 1982. Knowledge of the canon has also undeniably suffered from the increasing trend towards text-experience education, which allowed a great deal of room for the pupils' own preferences, even when these verged on laziness; the Internet could then be used to fill in the gaps. (One pupil could be overhead saying to another: 'Did you actually read that entire extract?'65). Another reason for the "underperformance" of this subject may be the fact that it is only examined by means of school exams rather than the central written exams. However, this latest suggestion is well beyond the mandate of this committee.

64 This idea was suggested by Dutch (and CKV) teacher Willy van Wetter of the OSG West-Friesland in Hoorn. Cf. the plea for a "cultural knowledge canon" in Raad van Cultuur 2005, especially p. 7-8.

65 Teacher Hannes Minkema was kind enough to share this anecdote with us. 


\section{Culture and the Arts (CKV)}

The relatively new and mandatory (for all pupils) subject CKV (CKV 1 in the Second Stage) offers a great deal of potential in terms of the canon. However, the subject is in its early stages and is still trying to establish its own identity, standards and form. According to pupils, the general atmosphere during lessons is often that of those endless "active holidays" Jan Blokker once described as typical of Dutch education. ${ }^{66}$ This is most likely one of the reasons that many CKV teachers are still insufficiently qualified: teachers from other subjects that have been roped in to help in spare hours. The good news is that many teachers with a pioneering spirit and sense of enthusiasm are getting involved. ${ }^{67}$

From the canon's perspective, the further development of this subject should ideally involve a little more knowledge and substance. (As the cultural sector in general might do well to emulate its colleagues from the exact sciences more often.) Canonical Dutch art from the The Hague School to Breitner (and from there to photography) is certainly deserving of attention, as are the Dutch representatives of major international movements (Koekoek as a romantic). CKV is currently oriented towards internationalism and modernity. The recent study on musical education by Bevers showed that while the key period between 1700-1850 (with all its major composers) is extremely dominant across Europe, the Netherlands is unique in terms of its focus on post-1950s music - which is to say: pop music. 68

\section{Social studies}

Mandatory subject social studies are represented by a modest number of hours in the upper forms of VMBO, HAVO and VWO. There are significant differences between the way in which the subject is taught at VMBO on the one hand and HAVO and VWO on the other. VMBO lessons focus on themes such as culture and socialisation, social inequalities, power and control, image formation and stereotyping. Though this is certainly substantive subject matter, the focus is mainly on the here and now; any links with the canon are indirect at best.

66 See, for example, Geldermans 2005.

67 Also see Onderwijsraad \& Raad voor Cultuur 2006, Paragraphs 5.3 and 5.4.

68 Bevers 2005, especially p. 42-44. It is interesting to note that the results of the same survey with regard to the visual arts are much more consistent: the twentieth century is dominant in all four countries. 
The subject is dealt with in a different manner at HAVO and VWO level. The plans for 2007 and beyond are based around the concept of citizen training (consisting of the themes rule of law, parliamentary democracy, the welfare state and the pluralistic society), with a clear focus on the historical dimensions. This offers many possibilities for linkage with some of the windows dealt with in primary education and the lower forms of secondary school. Canonical themes can be discussed and questioned, in keeping with the pupils' burgeoning development of their sense of judgement. What was the relationship between the royal Orange family and the birth of parliamentary democracy in the Netherlands? Which role did Hugo Grotius play in developing today's international law? Does Dutch society truly have

a strong tradition of tolerance, or is this a questionable hypothesis? What exactly did Einstein mean when he claimed to believe in "Spinoza's God"? Clearly, there are a wealth of opportunities here for truly preparatory higher education on the basis of the canon.

\subsubsection{Higher education}

Despite the fact that this area is even further removed from its mandate, the committee would like to take the liberty of making a number of comments with regard to higher education. Here too, it might be advisable to focus more on general education, in addition to normal disciplinary training. The committee would tend to agree with Paul Scheffer who, in his speech at the opening of the academic year in 2002 at the University of Amsterdam, referred to the university as the "most advanced school of citizenship", and called for a more robust (and broad) intellectual basis, through the curricula. ${ }^{69}$ The committee invites universities and professional education institutes (see recommendation 10) to take up their social responsibility in this area by assessing what could be done to improve the general development of their students - the future elite of the Netherlands - and strengthen their academic environment. 70 
Incidentally, the canon not only deserves a place in the teaching at universities (and professional education institutes), but also in their research projects. The Paradoxes of De-Canonization: New Forms of Cultural Transmission in History project at the Erasmus University plays a pioneering role in this respect. ${ }^{71}$ The committee is pleased to see that the "Cultural dynamics" programme of the Dutch organisation for scientific research (NWO) has devoted attention to processes of (de-)canonisation. This also serves as a prime example of the considerable societal significance of humanities studies.

RECOMMENDATION 10 Higher education: assess how the concept of "the most advanced school of citizenship" can be given concrete form - VSNU, HBO council

\subsection{Teachers and their "baggage"}

Are all our teachers sufficiently qualified to provide canonical education? Although we did not commission any systematic study in this area, a number of specialists from various areas of expertise did convey their concerns to us, especially with regard to the younger generations.

Professional knowledge has devaluated sharply in comparison with skills over the past few decades. Teaching methods also played a less significant role in the past. It was teachers - often potential intellectuals who had not been able to gain entry to university due to their backgrounds and had worked themselves up the ladder by means of teaching certificates - who took centre stage. ${ }^{72}$ Since that time, a diametrically opposed development has taken place: teacher-training institutes are suffering from a brain drain in the direction of universities and business. The consequences are further exacerbated if teacher shortages are addressed by lowering entry qualifications. In parallel to these developments, schoolbooks became more important and voluminous (and more expensive!), while teachers' professional knowledge deteriorated considerably.

See www.fhk.eur.nl/onderzoek/paradoxes.

f. Van Essen 2006. Despite arguing against the idealisation of teaching in the past on page 349, this book also contains many such examples. The final remarks (p. 350) place a greater focus on knowledge and cultural "baggage" as the main preconditions for improvement of teacher training institutes. The same point was stressed in the Koersen op meesterschap report by the HBO council in 2004. Also see Onderwijsraad 2005a, especially Chapter 4 and Onderwijsraad 2005b. 
These days, the method dictates the lessons; at first sight, there may be nothing wrong with taking a tried and trusted course. However, teachers now find themselves in a position where they have few options but to follow the direction pointed out by the book, especially where the route has to be harmonised at departmental level. In addition, the lesson schedules schools impose upon their teachers and pupils often leave so little breathing room that flexibility is almost or entirely out of the question. The overriding sense is that of too much subject matter in too little time, within a strictly-regulated, inflexible system. In the week following the death of Gerard Reve, Dutch lessons at a "gymnasium" [pre-university school] failed to even touch upon his work, despite the endless stream of newspaper eulogies; teachers most likely felt they could not diverge from their goose step along the trim little pre-designated path.

These developments - common in some form or another throughout the entire education sector - are having the greatest impact in the areas with the greatest relevance to the historical and cultural canon. Many of the partners consulted in preparation for this report spontaneously burst into praise of that one inspiring teacher from their own school days. (Never mentioning, it should be pointed out, that wonderful schoolbook!) Despite the fact that nostalgia can be somewhat distorting, teachers were keen to impress upon us that stories from the heart are the best possible way of enthusing children. Younger teachers, however, have less storytelling skills and less "baggage" from which to derive stories in the first place.

The canon is not some huge chunk of knowledge to be consumed through private study; a guide, a broker is required. This can be the neighbour from across the street, a books salesman or professor Henk van Os; the cases in which teachers have played this role are innumerably more frequent, though. As schools are the only place children are more or less guaranteed to come into contact with the canon, they still have the greatest task in this regard. Ideally, teachers should be equipped to bear this responsibility, both in cognitive terms and as regards the study programme. If we are to entrust this task upon them with a clear conscience, it is essential that we invest more in our teachers. ${ }^{73}$ An oft-heard comment in discussions on education is: 
give the subject back to the teacher. To which we would like to add: give the teacher back to the subject.

The relationship between teaching methods and subject content at teacher-training institutes for primary and secondary education is subject to considerable fluctuations. Based on the analysis of a series of study guides, the Education Council concludes that the percentage of PABO and secondgrade teacher-training institute curricula devoted to subject content has declined from around $80 \%$ in $1980 / 1981$ to less than $40 \%$ in $2004 / 2005 .{ }^{74}$ This constitutes a significant change; at present, the PABO is mainly a vocational training institute for the education sector. The consequences of this development can be felt even more clearly in the second-grade training institutes: here, students study to become "general teachers", without specialising in any given subject. This development is underpinned by a conscious choice, rooted in the competency-based teaching methods that have been so prevalent in the education sector of late.

If we compare the current situation with that of twenty-five years ago, the amount of face-to-face time teachers can offer at an average PABO has declined severely. As a consequence, we must surely doubt whether new generations of teachers are sufficiently equipped to teach the historical and cultural canon. Such education requires a surplus of knowledge, rather than a deficit. This is why the committee recommends that the curricula at teachertraining institutes should prioritise subject content. This applies to both PABOs and second-grade teacher training institutes.

\section{RECOMmEndation 11 A greater focus on subject content at PAB0s and teacher-training institutes - managements of PABOs and teacher-training institutes, and Ministry of $0 \mathrm{CW}$}

This recommendation could be interpreted as being negligent with regard to the interests of general teaching methods and educational theory within the teacher-training institute; however, this is not our intention. Although a common occurrence in practice, neither subject content nor teaching methods deserve to be set against one another. Good "classroom management" skills, as they are referred to in modern education, are just as vital to a good teacher as his or her expertise with regard to subject content. Having made this 
assertion, though, one must also recognise that old imbalances have merely been swapped for new ones. ${ }^{75}$ The fact that Dutch children know too little of their own (cultural) history nowadays seems to have been caused in part by the fact that their teachers also lack the necessary knowledge.

It may also be time to further harmonise the entry levels, ambitions, and study duration at the various teacher-training institutes. VWO graduates taking up a university study in the field of, for instance, physics (often with 9 out of 10 marks for the subject at their final examination) are unquestioningly expected to invest five years in full-time study. Perhaps intake pupils from the $\mathrm{MBO}$ - who make up $40 \%$ of the total PABO population these days are simply undereducated by the time they finish their four years of PABO, in view of the demands we currently make of our teachers?

\section{Refresher courses}

Upgrading teacher-training curricula in terms of subject content alone will not suffice. Firstly, it will take some time for such curricular changes to yield results at school. In addition, new views, questions and possibilities that are also of great relevance to the current generation of teachers will continue to pop up. This canon design is but one example. This is why the committee has chosen to advocate additional refresher courses based around the canon. We would suggest - amongst others - practical courses on both general teaching of the fifty windows as well as the teaching of specific target groups. Canonical education within the multicultural context, for example, brings up a whole new set of questions. There is a need for more knowledge on the possibilities for trans-cultural exchanges with regard to the canon; for further exploration of the "global canon" (cf. Recommendation 27), and training for teachers that have little familiarity with this way of thinking and working. ${ }^{76}$

In an effort to increase teachers' "proficiency" in terms of the recently approved Education Professions Act, we would suggest that school management invest in both teaching skill and content-based refresher courses.

This is why the advisory report by the Education Council (2005a, p. 62) recommended a fiftyfifty ratio.

76 Here too, we would like to stress that the issue is opportunities as much as it is problems. It may, for example, prove fruitful to demonstrate how certain western developments occurred earlier in history in other parts of the world: paper and the printing press in China, as well as the early form of humanism taught in Arabic schools. For this last reference, see Makdisi 1981 and 1990. 
These refresher courses must be well facilitated for the teachers in terms of both time and money. One way of achieving this would be to hold the courses on workdays at the schools themselves. ${ }^{77}$

\section{ReCOMmendation 12 Develop refresher courses - National educational centres in cooperation with the Ministry of $\mathrm{OCW}$}

\subsection{Cultural institutions}

Schools are not the only platform for the canon. Museums, libraries, all sorts of other cultural institutions and the media can - each within the framework of their own responsibility and expertise - all play a significant role in engendering knowledge and enthusiasm in this area. In accordance with the prime directive, the canon committee has focused mainly on the canon for and in the education sector; however, if we are to paint a sufficiently broad overall picture, we must also devote some attention to the way in which the various cultural institutions relate to our concept. This was (justifiably so) a part of our broader objective. The following section delves into this topic, listing a broad range of current initiatives that (could) tie in with our subject and a number of projects we would like to see in development. As this grande parade clearly illustrates, the canon is a phenomenon with a broad reach, which is (re)generating interest from across the board, and has a great potential to increase its appeal further still. We hope the recommendations in the following section can inspire certain institutions and individuals to undertake canon-related activities.

\section{RECOMMENDATION 13 Further the debate on this report and} the issues it raises within the cultural and heritage sector

\section{Collaboration with schools}

If we are to achieve the greatest possible degree of relevance - and we are pleased to see this happening more and more often - cultural institutions should seek out schools, and vice versa. Dutch schools organise excursions to museums on a regular basis. The Muiderslot alone is visited by some

77 As of 1 August 2006, the Education Professions Act (BI0) has become effective. Under this act, teachers, school managers and others working in the primary and secondary education sector are obliged to maintain and update their "skills" (See, amongst other sources, www.lerarenweb.nl). 
20,00o Dutch school children annually (schools prepare for these visits by means of a learning package). Naturally, a visit to this castle (especially after it was recently renovated for far greater visitor access) is a much more vivid experience than any wall chart or website could ever hope to offer, just as the Archeon gives visitors a sense of daily life in a medieval city, Neeltje Jans provides the most acute sense of the flooding disaster and the physical sensation of writing with a quill in the scriptorium at the Meermanno museum opens the distant window to Hebban olla vogala once and for all. The canon committee strongly supports such hands-on experience of the past, and has set up a special section on the entoen.nu site with tips for excursions and visits to historic locations for each window.

RECOMMENDATION 14 Link excursion sites to entoen.nu

- Netherlands Museum Association

The committee would be pleased to see an easing of the restrictions on such external activities: at present, these restrictions are often of a financial nature in the case of primary schools, and related to time-constraints in the case of secondary schools. Much more can be achieved in this area with appropriate financial support and goodwill. The highest classes of all primary schools in the municipality of Nunspeet are all guaranteed an annual visit to the Rijksmuseum, thanks to a private fund - of far-from astronomic proportions. ${ }^{78}$

RECOMMENDATION 15 Studies with regard to excursions in Primary and Secondary Education - Ministry of OCW

Conversely, the canon can also come to schools; the committee sees great potential in this area for guest speakers in the classroom. The formula used by Schrijvers-School-Samenleving [Writers-School-Society] in introducing school children to literature (by means of visiting writers; this method is now also being applied in primary schools, with the help of children's authors) is suitable for broader application. The recent “Veterans' Stories" project was set up along the same lines. Evidently, such stories from eyewitnesses and others able to recount historical events from firsthand experience can be extremely 
effective in the classroom. Although this is rather obvious with regard to World War II, there are many more possibilities for opening up both local and national canonical windows with the help of such "historical interpreters". There is undoubtedly a lot of activity in this area through private initiatives; teachers working with well-known (grand)parents or locals; however, the committee could envisage the creation (via entoen.nu?) of a digital market place to facilitate the harmonisation of supply and demand for classroom talks related to certain windows. Such visits would also be extremely beneficial in stimulating contact between the generations, and almost form a goal in themselves as such. ${ }^{79}$

RECOMMENDATION 16 Exploration of "eyewitnesses in the classroom" project - Ministry of $\mathrm{OCW}$

The committee is also an outspoken proponent of effective cooperation at municipal level between archive services, archaeological services, local museums/ monuments and schools. This is even a sine qua non where the local canon is concerned, but there are more benefits on offer here. As an added advantage, coming into contact with such institutions helps school children gain some conception of what it takes to preserve our cultural heritage. The technology this involves nowadays can also help lend this interaction with the past a unique, modern flavour instead of a caricatured mustiness.

\section{RECOMMENDATION 17 Discuss the options for activities geared to this design - Royal Association of Dutch Archivists, National archive, provincial and municipal archives}

When the plans surrounding the fifty windows were presented to the teaching staff of various primary schools, there was an immediate call for support by means of Schooltv, preferably in the form of short, attention-grabbing films (approximately fifteen minutes in length) that could be used to introduce lessons on windows. Perhaps Teleac/NOT could create such a series as an

79 As one participant at a KNAW meeting on "Human aging" put it: (19 June 2006): if senior citizens do not learn about young people's perspective on the world on a regular basis, they become "immigrants in time"; young people, conversely, then become "historyless'. A wonderful plea for the value of "generativity" can be found in Kees Schuyt's book (2005, p. 86-88) De stuifzandsamenleving. 
accompaniment to the fifty windows. Such an initiative would certainly be an incredible help in implementing the canon. 80

RECOMMENDATION 18 School television: a series of programmes on the canon with a length of approximately fifteen minutes per window - Teleac/NOT

The enormous video and radio archives at the Netherlands Institute for Sound and Vision (the former National Audiovisual Archive) can also play a supporting role in teaching the canon at schools. Especially via the educational application Teleblik, which makes these audiovisual archives accessible in the classroom.

RECOMMENDATION 19 Link digital media-archives to the canon site - Netherlands Institute for Sound and Vision (NIBG), archive and library sector

The proposals highlighted above are ideally suited to the Culture \& School programme, an initiative born of the merger between the departments of Culture and Education in 1994, aiming to bring cultural and heritage institutions in contact with schools. ${ }^{81}$ One of the main objectives was to reach young people who do not regard history and museums as part of their natural environment, in order to ensure that cultural facilities become a familiar part of their lives. The committee regards Culture \& School as an important medium in the further development of the canon in school and society.

RECOMMENDATION 20 Assess (potential for) collaborations between schools and cultural institutions, and stimulate these where possible - VNG, Culture \& School

\section{Cultural institutions and the canon}

Schools need not always play a central role in the canon-related activities of cultural institutions; independent initiatives can also be just as effective. Museums are a case in point in this regard, playing a vital part in increasing

80 This is in line with a scheduled Teleac/NOT project: a nationally accessible visual library that can be used for years to come, free of charge, by non-profit institutions such as museums, libraries and schools. 
the visibility of the Dutch canon. In addition, they also work to increase its scope and diversity, thus helping to open up the canon - not just for school children, but for parents and other adults, including a great many non-Dutch nationals. Charting this horizon properly would require a separate report. We will limit ourselves to a general comment, with regard to the attention museums devote to their "permanent collection" in addition to - and sometimes versus - special exhibitions. The latter seem to be the most effective way of attracting a broad audience, as witnessed by the unprecedented number of visitors queuing up for Repin and Akhenaton. Such exhibitions can play an important role in the rediscovery of forgotten historical figures, showing the public there is more under the sun than Tolstoy and Tutankhamun. This approach has now become so dominant that permanent collections are almost regarded as being “a bit mundane”. Without wanting to be too patronizing, the committee would recommend that museums assess whether - and if so, how - the basic story of their collection (which, after all, represents their canon) could be presented more effectively, in order to make sure the focus of attention does not shift overly towards the hypes. Two examples of our proposed approach are the Rijksmuseum's current process of reinvention and the ongoing renovation of the Letterkundig Museum.

The renovated Rijksmuseum will open its doors in a few years time. The new layout is based around a concept whereby future visitors will follow a route leading from 1200 to the present day. The integration of art in cultural history plays an important part in this concept, as does the representation of related areas such as the history of architecture, literature and ideas. The new layout was also designed to showcase the relationship between the Netherlands and other nations, while reaching an international audience, the traditional Dutch audience and the potential audience of recent immigrants alike. To this end, the Rijksmuseum will strive to base its exhibitions more around the historical context of art, rather than any specific stylistic framework.

The Letterkundig Museum is also currently involved in a drastic remodelling effort. The current overview exhibition, starting in 1750 and limited to the Netherlands, is scheduled to make way for a selection of 100 "heroes of the mind" - from Spinoza to Bomans - from the post-medieval period in the Netherlands and Flanders.

No matter how different, the main thrust of both renovations has a great deal in common with the philosophy behind our design: the character- 
istic selection, a sincere focus on landmark pieces; the chronological order; a focus on the story and a contextual approach. Obviously, the two projects are yet to be realised, but other museums are also adopting new strategies in line with the essence of the canon committee's design. One example in this regard would be the Nieuwe Land Museum in Lelystad, where engineer Lely unfolds his dream of the Netherlands in the year 2000 by means of a convincing virtual play; the Arnhem Open Air Museum, where visitors will now be able to find a Moluccan barracks camp inbetween the farmhouses and potato starch plant; the Tropenmuseum, with its popular and muchacclaimed permanent collection on Dutch colonialism; and the Jewish Historical Museum, which opts to educate its visitors by emphasizing that the building was once used as a synagogue. In line with these and similar examples, the committee would like to propose the development of various strategies in order to apply the canon in a museum-based context.

\section{RECOMMENDATION 21 Hold consultations on the development of relevant initiatives - Netherlands Museum Association}

In line with the above, we would also like to devote some attention to the current initiatives with regard to the - possible - construction of a museum of Dutch history. ${ }^{82}$ We understand the broad appeal of such an initiative, and are well aware of its correlation with the proposals we are presenting here. Despite the broad range of alternatives and the different obstacles each may involve, we are pleased to see broad political support for such an initiative. A fundamental decision in terms of the formula and location should be taken in the short term; pending such a decision, however, an assessment can be made as to the best way of interweaving the canon into the design of the preferred alternative.

The committee regards the (alternating) exhibition "Legacy of the Netherlands", currently being organised by the Royal Library of the Netherlands in collaboration with the National Archive as a good example of the way in which libraries can apply the canon. At a local level, public libraries (in collaboration with local archives) might consider organising similar

81 One of the Culture \& School projects is a voucher system for the subject of Culture and the Arts, set up in collaboration with the Cultureel Jongeren Paspoort foundation.

82 0n 27 June 2006, the Lower House of the Dutch parliament approved - across party lines a motion to establish a museum for Dutch history. 
initiatives based around the local canon. They could certainly strive to visibly present material for use in school assignments and talks on the subject of canonical windows, both locally and nationally. Whether or not they should dedicate special display cases with books and multimedia to the fifty windows and/or canonical Dutch literature is entirely up to them. Although this could serve as an attractive eye-catcher and an "anchor", the committee does not, under any circumstances, wish to isolate our canon from the rest of the collection or try to hype it up as a "brand".

\section{RECOMMENDATION 22 Hold consultations on the development of} relevant initiatives - Association of Public Libraries

The organisation Anno has been working to stimulate historical interest amongst a broad audience since 2001. It does so through various means such as the website www.anno.nl, a periodical "centrefold" in the free newspaper Sp!ts, travelling exhibitions in shopping centres and libraries, and organising the Week (including a special Night) of History. The Anno website features an extensive section aimed at supporting history education in the VMBO sector. The website - often referred to on entoen.nu - offers supplementary materials on almost all of the canon's historical windows. If our proposal is accepted, it would seem evident to opt for a closer form of collaboration.

The relationship between the public broadcasting service and the canon is a precarious one. In addition to producing documentaries in this area on a regular basis, the public broadcasting service also has a range of excellent series on history, classical music and the visual arts (literature and television have always been somewhat uneasy bedfellows, which is strange in light of the strong literary tradition in the Netherlands). However, the broadcasting sector has indicated that it will become increasingly difficult to find sufficient means and good timeslots for this type of subject matter in the future.

The committee finds this somewhat surprising, to say the least; in our view, this should be the main focus of the public broadcasting sector, which aims to be more than just a diluted version of the commercial channels with extra added bureaucracy. ${ }^{83}$ Although it may be somewhat of a cliché to use the BBC as an example, it must be pointed out that they did - once again - deliver in this respect: Simon Schama was commissioned to make a spectacular television 
series - now available on a DVD with additional material and special features on the history of England from 3000 BC to the present day.

\section{RECOMMENDATION 23 Hold consultations on the development of relevant initiatives - Public Broadcasting Service}

\subsection{Market and society}

Our committee has even less of an overview with regard to the application of its design in the market and broader society than it does in the case of the cultural institutions. Nevertheless, we would like to take this opportunity to offer a few suggestions with regard to initiatives in these sectors.

\section{Market}

Despite the prevalent scepticism in the cultural sector, the free market regularly proves itself willing to take the canon further than the elite had ever thought possible. The Kruidvat drugstore chain, for example, has promoted and sold the works of Mozart, other classical composers, various Russian writers (albeit not the classic Russian canon) and the collected works of Couperus. Out of the three future scenarios for "high culture" in the Netherlands in the year 2000 as projected by the Social and Cultural Planning Office - marginalisation, consolidation or reappraisal - the second and third options can clearly not be ruled out by any means. ${ }^{84}$ This is in no way limited to an older audience; a marketing survey conducted in Sweden several years ago showed that history is by far the most popular theme for new games and toys. 85 The Netherlands has also seen a number of historically-oriented games and toys released in the market over the past few years. 86 On a slightly more reflective level, the Plaatsen van herinnering project (Bert Bakker publishers) offers a more essayistic form of entoen.nu. Finally, we would like to point to a

84 Van den Broek and De Haan 2000.

85 Information provided by Fine Trossèl, former marketing manager at Jumbo.

86 This includes the Jumbo card game Vroeger of Later [Sooner or Later] (which can now be played online via www.vroegeroflater.nl), Kwartetspel Vaderlandse geschiedenis [Dutch History Happy Families] from Verloren, the Indisch herinneringskwartet [Dutch East Indies Commemorative Happy Families] from Stichting Pelita, the Werelderfgoedkwartet [World Heritage Happy Families] from Unesco, the Het Grote Geschiedenisspel [Great History] board game from Scala Leuker Leren. We were not able to find a historical memory-game (with 2 x 50 cards?) among the products on offer. 
plan recently unveiled by producer Joop van den Ende, who is seeking to revive classic plays in his Dutch theatres. In the view of the committee, this plan in and of itself is a positive sign as to the canon's continuing relevance and potential for modern-day appeal. We are especially pleased to see the general sentiment that gave rise to this initiative, which was also the basis for the establishment of our committee: a renewed focus on the past and the great wealth it has to offer.

We would not be so bold as to make any further recommendations in this area, but are eager to see how the free market responds to our proposals. The fact that educational publishers may be expected to study our canon design and develop relevant initiatives is almost too obvious to mention here.

\section{RECOMMENDATION 24 Hold consultations on the development of relevant initiatives - Educational publishers}

\section{Society}

The canon permeates our society in more ways than we could list here, even if we were to limit ourselves to the fifty windows included in our proposal. We hope parents will also take our design to heart, and express their views as to how the canon is dealt with at school. However, it is essential that canonical learning is not limited to the classroom. Ideally, we should see its reflection throughout the public domain, both as a learning tool and a source of enjoyment. To give but one rather literal example: signposting in the Netherlands. One need only travel the highways of Belgium, France and Germany to find references to the canon; striking signs referring to important regional events, historical figures or monuments. Our committee feels this is an excellent way to stimulate awareness of the historical and cultural dimensions of the world around us. It is perhaps typical of the Netherlands' rather poor sense of its own history that we do not have something similar in this country, at least not in the form of an organised, nationwide initiative. We would like to see the ANWB [Royal Dutch Touring Club] come up with an appealing, not too faint-hearted Dutch version.

RECOMmENDAtion 25 Explore the possibilities (local and national) for canon-related information on signposts along the Dutch road network - Ministry of Public Works, Transport and Water Management, ANWB 


\subsection{Willem van Oranje Fund}

The committee has over the past few years been approached frequently by individuals, companies and institutions in the process of developing initiatives to promote varying aspects of the canon. They all hoped to gain the committee's support, either in terms of content or on an idealistic and even financial basis. The committee has taken a reticent approach in this regard, as it was not mandated to assess such requests and has yet to find out whether its own work will stand the test of political, educational and societal criticism. The committee would support - on the analogy of funds such as the Fonds voor de Letteren [Literature Fund], the Fonds Stimulering Culturele Omroepproducties [Cultural Broadcasting Productions Incentive Fund], the Fonds Bijzondere Journalistieke Producties [Special Journalistic Productions Fund], the Nederlands Fonds voor de Film [Dutch Film Fund], etc. - the establishment of an institution with sufficient funds and expertise to provide an effective response to any qualified plans and enthusiastic initiatives based around the canon. This is why the committee would like to propose the establishment of a fund for projects with a nationwide scope aimed at promoting knowledge of and involvement in Dutch history and culture in the primary, secondary and tertiary education sectors and among the general public. ${ }^{87}$ Support from the fund should benefit both the supply and demand side of the spectrum, in other words; both creative project developers as well as groups of schools and teachers seeking to do something special with the canon.

One advantage of this approach would be that the government would then facilitate a broad range of valuable societal initiatives without taking on too much of a regulatory role. The formula also prevents the monopolisation of canon management by a single institution, and does justice to the diversity characteristic of any vital canon, which can continually generate new plans and initiatives. A swift implementation of this proposal would be advisable. The canon debate has sparked a great deal of ideas and plans that can now begin to yield their benefits. ${ }^{88}$ At minimum, the fund should be allocated an annual budget of 10 million euro.

87 Provinces could then set up funds for projects with a regional (or even local) scope. It goes without saying that any such project would require close consultations with the Prins Bernhard Fund in order to ensure a clear allocation of responsibilities.

88 From John 4:35; for the biblical canon and Dutch heritage, see www.bijbelencultuur.nl. 
The committee would recommend naming this fund after the only Dutchman truly deserving of the predicate "the greatest": Willem van Oranje [William of Orange].

RECOMMENDATION 26 Establish and stimulate Willem van Oranje Fund - Parliament in collaboration with the Innovation Platform 


\section{The canon in revision}

\section{Periodical maintenance of the canon}

I have seen Picasso and Mondrian, Bernini and Michelangelo,

Hieronymus Bosch and Hans Holbein. I have seen art of unsettling beauty and deep significance. But none more unsettling or radical than that of Marianne Schuit.

MICK VAN SCHOONEVELD AT WWW.DELAATSTESTAP.NL

\subsection{The ever-changing canon}

"History is a never-ending debate" is a well-known quote by historian Pieter Geyl (1887-1966). This is doubly true where it comes to the historical canon. Both the contents and the function of the canon are the subject of endless debate. This debate is not a symptom of the canon's demise, but rather of its vitality. After all, debate is one of the very purposes of the canon; topics can range from the significance of a Dutch canon to children of the MTV generation, to a concrete difference of opinion on the artistic superiority of either Rembrandt or Vermeer. Such debates are not entered into with the intention of ever finding a definitive answer; it is simply a good thing to keep discussing matters of beauty and importance. The fact that some reject or denounce the canon while others advocate extravagant choices simply serves to make that debate all the more intriguing.

If we examine the history of this ongoing debate, it becomes clear that the canon - both the Dutch and the international version - is of a great resilience and flexibility. Homer, Dante and Rembrandt have been an integral part of the canon for centuries now, and that is unlikely to change. However, our view of these great icons is, and will always remain, subject to change. While the prevalent eighteenth century view on Rembrandt was that of a misunderstood genius, we now regard him as a masterful strategist, 
manoeuvring skilfully amongst his various pupils and clients. The portrait of William of Orange is also constantly being repainted, not to mention Napoleon. Moreover, it should be pointed out that the contents of the canon are actually subject to change in certain areas. Historical research has dismantled figureheads from the old Dutch canon such as the Muiderkring culture group and Nova Zembla to such an extent that they now no longer feature in the fifty windows. 89 Conversely, it is safe to say Aletta Jacobs would not have been given such a prominent position in the canon fifty years ago. Although Dutch history lessons prior to 1940 did focus on the colonies, there was much less awareness of the important role of immigration and emigration in Dutch history than is currently the case in our post-colonial society. The canon too, it would seem, is an ever-changing entity.

As we approach the present day, the canon becomes highly temporal. Madame Tussaud's in Amsterdam has Pim Fortuyn on display amongst world leaders; the likeness of TV presenter Hennie Huisman has now found new use in the chamber of horrors. The general public is not the only capricious voice, though. In 1920, when the Royal Dutch Academy of Science was asked to offer its views on the establishment of an archive for Dutch film, the institution made it clear it saw no value in such an endeavour. Historian Huizinga (1872-1945) regarded film as "deathly mechanisation" of life, describing cinemas as "mundane and monotonous", and the medium as "not worth preserving". 90 Although the heritage of Dutch cinema is currently not featured in any the fifty windows, this may well be the case in future editions of the canon. As spectators of our own times and recent past, we are simply too close to judge what will be of lasting influence and significance. After thorough deliberation, our committee has opted for the current windows. Future generations, however, might well choose Pim Fortuyn over Drees, or perhaps value rapper Ali B over Annie M.G. Schmidt. Our recent past may also be subject to revaluation, with a window on the Golden Age ceding its place to Modern Devotion. And it would only take one spectacular archaeological finding to put the Vikings back in the centre of attention.

This is one of the reasons why the Minister's brief to the canon committee included the provision that we should develop a procedural recommendation for possible future adaptations of our design. The committee feels comfortable 
with this request, as we do not regard the fifty windows presented here - or even the underlying concept - as being definitive. Despite the fact that we have invested great care in both the concept and selection procedure, and regard our proposal as robust, this is not a canon set in stone. Like the road network, the canon also requires constant maintenance. In response to the minister's brief, the committee presents a concrete, tri-level proposal below. Each of the three levels is aimed at facilitating revision of our proposal.

First, though, we would like to take this opportunity to emphasize what we believe should be done if the current proposal were to be well-received: the completion of our efforts through the development of an international canon. This was in no way part of the committee's brief, and would certainly have to be thought through by a new body. Harmonisation with our concept would offer obvious advantages, but it seems certain that even the most fervent devotees of Goethe's teaching methods would not find fifty windows to be sufficient here. However, the immense value of the international canon requires - if there is sufficient support for this concept - that they flank and in all honesty - overarch the Dutch canon: with Goethe, Shakespeare, the pyramids, Dante, Stradivarius, the atomic bomb, the Alhambra, the fall of the Berlin wall, Fellini, Madame Curie, impressionism, democracy, the Sistine Chapel, Martin Luther King and Dostoyevsky, the Vietnam war, Voltaire, Keynes, Columbus, Churchill, Jugendstil, Einstein, Gandhi, the Temple Mount, Bach, Hitler, Darwin, the Incas and the Aya Sofia and perhaps even the Bayeux Tapestry, the fall of Constantinople and the fountains of Bernini. As this list illustrates, such a canon would be a mind-boggling venture, and might even prove too much for the committee assigned with its completion. The committee for the Development of the Dutch Canon would like to emphasize that - although our perspective was a national one - the value of the canon in the Netherlands does not end at the borders of our nation. What is more, we regard the value of foreign canonical windows as being equally self-evident, perhaps even more so as the Dutch canon begins to take root. Naturally, the secondary education system would be the most appropriate arena for the implementation of such a canon.

RECOMMENDATION 27 Consider the initiation of a process aimed at developing an international canon for the Dutch education sector - Ministry of $\mathrm{OCW}$ 


\title{
4.2 Concrete procedures
}

One factor that will ensure the revaluation of our design is the debate this report will spark. This discussion is expected to take place across a broad range of forums, at many instances. The committee is especially eager to see the educational sector study the report thoroughly in the short term. The report should be discussed at individual schools, both at management level as well as by the various relevant sections; naturally, the debate should also include teachers associations at both primary and secondary school level.

\begin{abstract}
RECOMMENDATION 28 Discuss this report at individual schools, both at management level and in the relevant sections RECOMMENDATION 29 Discuss this report in teachers associations for both primary and secondary education
\end{abstract}

The committee would like the opportunity to respond to the main points of criticism and debate in early 2007.

\section{RECOMMENDATION 30 Respond to main points of criticism and debate sparked by this report - Canon Committee (Spring of 2007), under the supervision of the Ministry of $0 \mathrm{cW}$}

The website - and especially the "wiki function" developed in parallel to our design will also offer a permanent open forum for every possible kind of comment with regard to the canon. This forum will serve as a demonstration of the "debate without end" referred to earlier. The wiki application will also allow for "regular maintenance" of the canon. Specifying details, adding new ideas for lessons and supplementary stories, pointing out new children's books, websites and audiovisual sources - these are all excellent means to help perfect and update the canon. They will also help establish - more or less automatically - if certain windows are eligible for replacement in a few years time.

However, our proposal and design also require "major repairs". To this end, the committee proposes the formation of a new committee in five years time - in line with the rhythmicity of the attainment targets - in order to reassess the entire canon. This could result in a broad range of modifications: 
based on experience with the - by that time - tried and trusted design, based on new requirements with regard to education and/or a different view of the canon's purpose and contents.

\section{ReCOMmendation 31 Reassess the Dutch Canon in five years time - Ministry of $\mathrm{OCW}$}

At the other end of the spectrum, this canon design obviously requires maintenance via the entoen.nu website in the immediate term. The situation is actually rather delicate: the day the site goes online - along with the wiki function and necessary editorial staff - marks the de facto completion of the canon committee's task. In order to prevent the site - which has great potential - from languishing in cyberspace, it is extremely important that the responsible officials - starting with the government that initiated this process - find a way of getting entoen.nu to work properly in the short term (cf. Recommendation 3). 


\title{
CHAPTER 5
}

\section{The Canon in position}

\section{Recommendations and desiderata (including: at what price the canon?)}

The dead are at the mercy of the living.

\author{
Attributed to french poet Charles Péguy (1873-1914), \\ KILLED IN THE BATTLE OF THE MARNE
}

The committee will provide an overview of its main recommendations in this final chapter, ordered along thematic lines with references to the relevant chapters. In addition, we have addressed each recommendation to the party we feel is most qualified to ensure its implementation.

Some of our recommendations will require special funding, and any requests for such funding are merely implied. The committee did not regard it as its task to ask for financial support. A great deal of our proposals can be implemented on the basis of conviction and goodwill, within existing frameworks and means. Along the way, however, we have become increasingly aware of various voids, desiderata and new opportunities with regard to the canon. This is why we are calling on the involved parties - with an emphasis on politicians - to do what they so often do: vote money for issues they regard as important.

We believe this request is fully in line with the Innovation Platform's 2006-2016 Knowledge Investment Agenda. This agenda calls for major additional investment to help the Netherlands become a "knowledge nation" in order to achieve optimal prosperity and well-being. The term knowledge investment generally calls to mind the sort of cutting edge technological research our country has been associated with for years - also see the windows on television, the port of Rotterdam and the natural gas deposit. However, we believe the quality of knowledge and innovation in this country would be well served by investment in general education and immaterial infrastructure. If knowledge 
were to be narrowed down to mere product development in aid of the global, commercial marketplace, we will end up with a regrettably one-sided climate, which - ironically enough - may turn out to be anything but innovative. After all, creativity is all about finding connections between diverse elements, and the ability to think out of the box. Could it be a coincidence that the world's most innovative economy, that of the US, is mainly driven by people who studied liberal arts prior to attending business school or receiving onthe-job training? ${ }^{91}$ British culture also places great value on a grounding in history or the classics prior to becoming, say, a banker or lawyer, while roman latin cultures seem to regard an intellectual background as a sine qua non for the higher levels of management. Studies of the psychology of learning have also shown that the stimulation of general knowledge during primary and secondary education can have a surprisingly positive effect on learning performance and later (professional) life. ${ }^{92}$ Viewed from this perspective, the canon represents a cultural capital with great potential yields.

The section below can thus be regarded as a list of concrete objectives in line with the additional billions per year advocated in the Knowledge Investment Agenda. Naturally, our wish list remains well within this amount. One of the most appealing aspects of this sector is, after all, the fact that incredible gains can be achieved at relatively low cost. The committee can scarcely imagine that a country that has professed such dedication to its history, canon, knowledge and education of late would not be able to find the financial means to do so. Each country, lest we forget, gets the canon it deserves, or - to a large extent - pays for. ${ }^{93}$ Florida on the creative city, arguing that industrial knowledge workers flourish best in a high-quality cultural ambiance.

92 With thanks to Prof. Jelle Jolles, Department of Neuropsychology, Maastricht University.

93 In 2000, US Congress unanimously approved a resolution to increase funding of history education following a study that showed the average American student had an extremely poor knowledge of history (Scheffer 2005, p. 16). 


\section{Recommendations}

\section{With regard to the report}

- Stimulate a broad debate on this report and the associated design in the world of politics, education and general society, and ensure follow-up - Ministry of Education, Culture and Science (OCW)

\section{With regard to the design (all processes under the supervision of the Ministry of $\mathrm{OCW}$ )}

- Produce high-quality chart (in various formats) and provide to schools and other relevant parties (Recommendation 1, § 2.3)

- Commission development of treasure chest containing objects from the windows (Recommendation 2, § 2.3)

- Commission management and expansion of entoen.nu website (Recommendation 3, § 2.3)

- Assess how creative subjects such as Culture and the Arts (CKV) can be anchored even more firmly in the design, in terms of both content and didactics (Recommendation 6, § 3.1.1)

- Further reflection on the place of the canon in the upper forms of secondary education (Recommendation 8, § 3.3.1)

- Consider the initiation of a process aimed at developing an international canon for the Dutch education sector. (Recommendation 27, § 4.1)

\section{The education sector}

- Discuss this report at individual schools, both at management level and in the relevant sections (Recommendation 28, § 4.2)

- Discuss this report in teachers' associations

- General primary school teachers' associations; Secondary school teachers' associations for History, Geography, Dutch, Culture/Culture and the Arts and Social Studies (Recommendation 29, § 4.2)

- Support and encourage initiatives to develop didactics (including stimulating assignments and testing) as part of the canon's design - Ministry of OCW (Recommendation 4, § 3.1)

- A greater focus on subject content at PABOs and teacher-training institutes

- managements of PABOs and teacher training institutes, and Ministry of OCW (Recommendation 11, § 3.2) 
- School television: a series of programmes on the canon with a length of approximately fifteen minutes per window

- Teleac/NOT (Recommendation 18, § 3.3)

- Develop refresher courses

- National educational centres in cooperation with Ministry of OCW (Recommendation 12, § 3.2)

- Assess the condition of school libraries (especially in primary schools) and provide support if necessary - Ministry of OCW (Recommendation 5, § 3.1.1)

- Commission studies with regard to excursions in Primary and Secondary Education and provide support if necessary

- Ministry of OCW (Recommendation 15, § 3.3)

- Higher education: assess how the concept of "the most advanced school of citizenship" can be given concrete form

- VSNU, HBO-council (Recommendation 10, § 3.1.3)

\section{Provinces and municipalities}

- Local canon initiatives in collaboration with educational and heritage institutions at local level

- Erfgoed actueel and VNG (Recommendation 7, § 3.1.1)

- Assess (potential for) collaborations between schools and cultural institutions, and stimulate where possible

- VNG, Culture \& School (Recommendation 20, § 3.3)

\section{Cultural institutions}

- Further the debate on this report and the issues it raises within the cultural and heritage sector - to be supervised by Ministry of OCW, Department of Culture (Recommendation 13, § 3.3)

- Discuss the options for activities geared to this design - Royal Association of Dutch Archivists, National archive, provincial and municipal archives (Recommendation 17, § 3.3)

- Hold consultations on the development of relevant initiatives - Netherlands Museum Association (Recommendation 21, § 3.3)

- Hold consultations on the development of relevant initiatives - Association of Public Libraries (Recommendation 22, § 3.3)

- Hold consultations on the development of relevant initiatives - Public Broadcasting Service (Recommendation 23, § 3.3) 
- Develop digital domain "the canon in Dutch literature"

- Digital Library of Dutch Literature (Recommendation 9, § 3.1.3)

- Link excursion sites to entoen.nu

- Netherlands Museum Association (Recommendation 14, § 3.3)

- Exploration of "eyewitnesses in the classroom" project - Ministry of OCW (Recommendation 16, § 3.3)

- Link digital media archives to the canon site

- Netherlands Institute for Sound and Vision (NIBG), archive and library sector (Recommendation 19, § 3.3) Market and society

- Hold consultations on the development of relevant initiatives - Educational publishers (Recommendation 24, § 3.4)

- Explore the possibilities (local and national) for canon-related information on signposts along the Dutch road network

- Ministry of Public Works, Transport and Water Management, ANWB (Recommendation 25, § 3.4)

\section{With regard to the process}

- Establish and stimulate Willem van Oranje Fund

- Parliament in collaboration with the Innovation Platform (Recommendation 26, § 3.5)

- Respond to main points of criticism and debate sparked by this report - Canon Committee (Spring of 2007), under the supervision of Ministry of OCW (Recommendation 30, § 4.2)

- Reassess the Dutch Canon in five years time - Ministry of OCW (Recommendation 31, § 4.2) 


\title{
Closing remarks
}

\author{
A society is defined not only by what it creates, but by what it \\ chooses not to destroy. \\ JOHN C. SAWHILL, FORMER PRESIDENT \\ OF THE NATURE CONSERVANCY, USA
}

The canon committee was born under something of a bad sign, with studies showing a declining knowledge of Dutch history and culture among an everincreasing part of the population. During the year we spent in preparation for this report, we found the scope of this concern to be much broader than the canon alone. We heard similar complaints from a broad range of sources: complaints about poorer knowledge of arithmetic and mathematics, a lack of appreciation for craftsmanship in technology education, managers with no affinity for the products of their sector and higher management staff with no affinity for the shop floor. Content-based knowledge seems to have suffered from an at-times exaggerated focus on global competencies in many parts of our educational system and society. (Seemingly having forgotten that know-how and knowledge can also be vital competencies.) We hope this canon report stimulates further contemplation on the relationship between subject content and skills. As it would appear, the issue of declining knowledge is not limited to the cultural sector alone.

However, the canon in the Dutch education sector deserves better than such a defensive incentive. We hope this proposal will demonstrate that what many initially regarded as cultural "dyke-watching" can take on an offensive character in the positive sense of the word. A revaluation of the canon can stimulate initiatives that help keep important and valuable elements of our past alive and relevant. This will, however require a strong inner conviction: faith, if you will, in the intrinsic value of the canon, in the wisdom, beauty and pure enjoyment it has to offer us all. What started as a problem, 
in other words, has become an opportunity: a chance to dwell upon some of the things that truly matter.

The process itself actually confronts our society with a rather profound question. How should we go about maintaining immaterial things, how can we guarantee that this is done properly? We hope this report can serve as a basis for some incisive debates on this issue.

One would hope that the process of canon design could also spark a wider debate that transcends our fifty windows: a broad discussion throughout society about what we do and do not teach our children, and the way in which we do so. The educational debate in politics, the sector itself and broader society often seem to be about everything other than the actual contents of the school books and lessons. There may be a historical reason - and even justification - for this phenomenon, but that does not discharge us of our shared responsibility for that content. Freedom of education cannot be a reason to avoid the debate on content, which - in the case of the canon can be extremely enriching and inspiring. With that in mind, the committee can only look forward to the debate this report will undoubtedly spark. 


\section{Literature}

Aarts, C.J., M.C. Van Etten (1990), Domweg gelukkig, in de Dapperstraat: De bekendste gedichten uit de Nederlandse literatuur. Amsterdam: Bert Bakker (23rd edition 2004)

Angvik, Magne, Bodo von Borries (ed.) (1997), Youth and history: A Comparative European Survey on Historical Consciousness and Political Attitudes among Adolescents. (2 parts + CD-ROM) Hamburg: Körberstiftung

Anrooij, Wim van (2006), Handschriften als spiegel van de Middeleeuwse tekstcultuur. (Inaugural lecture in Leiden). Leiden: Leiden University

Bank, Jan, Gijsbert van Es, Piet de Rooy (2005), Kortweg Nederland: Wat iedereen will weten over onze geschiedenis. The Hague: Anno

Bazelmans, Jos (2005), Afval en erfgoed: Waarde en waarden in de archeologie en de archeologische monumentenzorg. (Inaugural lecture VU, 29 September 2005, via www.archis.nl)

Beek, Wim van \& Marianne Verhallen (ed.) (2004), Taal, een zaak van alle vakken: Geïntegreerd taal- en zaakvakonderwijs op de basisschool. Bussum: Coutinho

Beliën et al, H. (2005), De canons: Wat iedereen wil weten over geschiedenis, literatuur, filosofie en wetenschap. Amsterdam: Bert Bakker

Bevers, Ton (2005), Canon en kunstvakken: Vergelijkend onderzoek naar eindexamenopgaven muziek en beeldende kunsten in vier Europese landen. (Cultuur+Educatie 13) Utrecht: Cultuurnetwerk Nederland

Blokker, Jan, Jan Blokker Jr. and Bas Blokker (2005), Het vooroudergevoel: De vaderlandse geschiedenis. Amsterdam: Contact

Brems, Hugo (2006), Altijd weer die vogels die nesten beginnen: Geschiedenis van de Nederlandse literatuur 1945-2005. Amsterdam: Bert Bakker

Broek, Andries van den and Jos de Haan (2000), Cultuur tussen competentie en competitie. Amsterdam: Boekmanstichting and Sociaal Cultureel Planbureau

Bruner, Jerome (1986), Actual minds, possible worlds. Cambridge MA 
Calmthout, Martijn van (2005), "Mijn land van Lorentz en Tinbergen”. In: De Volkskrant (12 March 2005)

Cornelisse, Wilma (2005), "Belangrijke gebeurtenissen, rijke verhalen, markante persoonlijkheden \& fraaie kunstwerken”. In: Nieuwsbrief onderwijspraktijk (2005) 7, p. 23-30

CPB (2006), Kansrijk kennisbeleid (СРB Document 124). The Hague: СРB (download via www.cpb.nl/nl/pub/cpbreeksen/document/124)

Curtius, Ernst Robert (1948), Europäische Literatur und lateinisches Mittelalter. Tübingen: Francke (11th edition 1993)

CVEN (1991), Het CVEN-rapport: Eindverslag van de commissie Vernieuwing Eindexamenprogramma's Nederlandse taal en letterkunde v.w.o. en h.a.v.o. The Hague: SDU

Davids, K. (2005), "Global History» en de "canon" van de Nederlandse geschiedenis. (KNAW lecture 13 June 2005). Amsterdam: KNAW

Dienst Openbare Bibliotheek Den Haag (2006), De literaire canon: Symposium 8 February 2006. The Hague: privately published

Doorman, Maarten (2004), Kiekertak en Klotterbooke: Gedachten over de canon. Amsterdam: Amsterdam University Press

Draper, Norman (2003), "Dust-up over history standards: Proposed social studies requirements are already being criticized”. In: Star Tribune (30 October 2003)

Duursma, Mark (2005), "Blik naar buiten is kenmerk van Nederlandse cultuur". In: NRC Handelsblad (19 January 2005)

Duursma, Mark (2005a), "Verwarring over nut van geschiedenis: Historicus Piet de Rooy over historische canon, politiek en patriottisme." In: NRC Handelsblad (10 March 2005)

Egan, K. (1988), Teaching as Storytelling: An alternative approach to teaching and the curriculum. Ontario: The University of Western Ontario

Empel, Martijn van (2005), "Hoe de cultuurcanon een succes wordt". In: Het Financieele Dagblad (14 March 2005)

Essen, Mineke van (2006), Kwekeling tussen akte en ideaal. Amsterdam: SUN

Geldermans, Anja (2005), "Jongeren geven hun mening over CKV". In: Bulletin Cultuur \& School 39 (October 2005), p. 12-17 
Greven, Jan (ed.) (2005), Verhalen van veteranen: Ingezet in dienst van de vrede. Nederlandse veteranendag als onderwijsthema voor 10- tot 15-jarigen. Enschede: SLO

Grever, Maria and Kees Ribbens (2005), "Canon vraagt om evenwicht”. In: De Volkskrant (1 March 2005)

Grever, Maria (2005), “Wat doen we met de canon?” In: Wilschut 2005, p. 21-30

Groot, Frans, "Cohesie en kritiek: De canon en het geschiedenisonderwijs ter discussie." In: Levend Erfgoed. Vakblad voor public folklore \& public history. 3 (2006) 1, p. 4-11

Haas, W. de (1999). Verhaal als opvoeding: Narrativiteit in pedagogisch perspectief. Kampen: Kok

Harmon ed., William (1990), The classic hunded. New York: Columbia University Press

Hekster, Olivier (2005), “Een problematisch begrip”. In: NRC Handelsblad (25 February 2005)

Henry, Julie (2004), “Hitler wasn't real, says one in 10 historically challenged Britons”. In: Telegraph.co.uk (4 April 2004)

Horst, Han van der (2005), Het beste land van de wereld: Waar komen onze normen en waarden vandaan? Amsterdam: Bert Bakker

Imelman, J.D. (1977), Inleiding in de pedagogiek. Groningen: Wolters Noordhoff Imelman, J.D. (2003), Verantwoording Cultuurpedagogische discussies Geschiedenis. Arnhem: CITO

IVGD (2006), Dit is geschiedenis: De toekomst van geschiedenis in de onderbouw van het voortgezet onderwijs. Amsterdam: Instituut voor Geschiedenisdidactiek

Kearl, M. [1994], "An investigation into collective historical knowledge and implications of its ignorance". See: www.trinity.edu/ mkearl/histignr.html

Kempers, B. (1999), “Onze cultuur zoekt dringend een nieuwe canon”. In: NRC Handelsblad (11 September 1999)

Khalili, Nasser D. (2006), Tijdslijn van de islamitische kunst en architectuur. Amsterdam

Kieskamp, Wilma (2005), “Juist tegenstellingen horen bij Nederland”. In: Trouw (2 April 2005) 
Kleijn, Koen, Sander Pleij (2005), “Bijles voor de natie”. In: De Groene Amsterdammer (11 March 2005)

Klein (et al), P.W. (1998), Een beeld van een academie: Mensen en momenten uit de geschiedenis van het Koninklijk Instituut en de Koninklijke Nederlandse Akademie van Wetenschappen. Amsterdam: KNAW

Klein, Stephan (2005), “Dappere docent”. In: NRC Handelsblad (23 February 2005)

Klein, Stephan (2006), “Clio’s "makeover». Over democratisch burgerschap, canons en didactiek voor het geschiedenisonderwijs.” In: Kleio 47 (March 2006) 2

Kleiterp (ed.), L.F. (1963), Leidraad, samengesteld door de inspectie van het lager onderwijs in de derde hoofdinspectie. Herziene en gecompleteerde uitgave 1949. Lagere scholen, klassen 1-6. Groningen: Wolters, 8th edition

Kohnstamm, Dolph en Elly Cassee ed. (2005), Nieuw Cultureel woordenboek: Encyclopedie van de algemene ontwikkeling. Amsterdam: Anthos

[Kulturkanon] (2006), Kulturkanon. Saernummer Kulturkontakten. Published by the Danish Ministry of Culture, January 2006, also see www.kum.dk/sw43295.asp

Laarhoven (ed.), Jan van (1987), John of Salisbury: Entheticus maior and minor. 3 volumes. Leiden etc

Leeuwen, Joke van (2004), Waarom een buitenboordmotor eenzaam is en waarom je Jansen heet als je Jansen heet en waarom eieren vroeger geen eieren waren en waarom we geen zeventigduizend letters hebben en nog veel meer over de taal die je nu leest. Rekkem: Stichting Ons Erfdeel

Lendering, Jona (2005), Polderdenken. De wortels van de Nederlandse overlegcultuur. Amsterdam: Athenaeum, Polak \& Van Gennep

Mak, Geert (2005), Gedoemd tot kwetsbaarheid. Amsterdam/Antwerpen: Atlas Makdisi, G. (1981), The rise of colleges: Institutions of learning in Islam and the West. Edinburgh: Edinburgh University Press

Makdisi, G. (1990), The rise of humanism in classical Islam and the Christian West. Edinburgh: Edinburgh University Press

Mathijsen, Marita, Herman Pleij, Thomas Vaessens (2005), “Dit zijn de boeken die iedereen gelezen moet hebben". In: NRC Handelsblad (5 March 2005)

Meijer et al, Maaike (1991), De canon onder vuur, Nederlandse literatuur tegendraads gelezen. Amsterdam: Van Gennep 
Moerbeek, Jozien (1998), Canons in context: Canonvorming in het literatuuronderwijs Nederlands in Nederland en Vlaanderen. Soest: privately published

Noort, Wim van, Rob Wiche (2006), Nederland als voorbeeldige natie. Hilversum: Verloren

Onderwijsraad (2005), De stand van educatief Nederland. The Hague Onderwijsraad (2005a), Leraren opleiden in de school: Hoe kan de kwaliteit van opleiden in de school worden gegarandeerd? The Hague

Onderwijsraad (2005b), Kwaliteit en inrichting van de lerarenopleidingen: Briefadvies aan de Tweede Kamer. The Hague

Onderwijsraad \& Raad voor Cultuur (2006), Onderwijs in cultuur: Versterking van cultuureducatie in primair en voortgezet onderwijs. The Hague

Oostrom, F.P. van (ed.) (1998), Historisch Tableau: Geschiedenis opnieuw verbeeld in schoolplaten en essays. Amsterdam: Amsterdam University Press

Oostrom, Frits van: "Mozes en de doortocht door de polder: Een historische kijk op leiderschap in Nederland”, ZOUT [KPMG corporate magazine] October 2006

Palm, Jos (2005), De vergeten geschiedenis van Nederland: Waarom Nederlanders hun verleden zouden moeten kennen. Amsterdam: Athenaeum, Polak \& Van Gennep

Pels, Dick (2005), Een zwak voor Nederland. Amsterdam: Anthos

Pols, Wouter (2004), "Vraagtekens bij het «wat» van de geschiedenis op de basisschool”. In: Kleio (2004) 7, p. 11-14

Poelman, Frits (2005), “Zonder jaartallen heeft geschiedenis geen verband”. In: Dagblad van het Noorden (8 March 2005)

Raad van Cultuur (2005), Van zwarte lijnen en witte tussenruimte tot vaste, klinkende, zinvolle werkelijkheid: Advies over het belang van het culturele lezen en leesbevordering. The Hague

Rensman, E., W. Bossmann (1996), "Willem van Oranje in 16-zoveel bij Dokkum vermoord”. In: Historisch Nieuwsblad 5 (1996), p. 16-21

Reve, Karel van het (1988), Zie ook onder Mozes. Amsterdam: Van Oorschot Ribbens, Kees (2004), "De vaderlandse canon voorbij? Een multiculturele historische cultuur in wording." In: Tijdschrift voor Geschiedenis, 117 (2004) 4, p. 500-521 
Ribbens, Kees (2006), “Canon vereist heroverweging”. In: Geschiedenis Magazine 41 (2006) 1, p. 43-45

Rooy, J. de et al (2001), Verleden, heden en toekomst: Advies van the committee Historische en Maatschappelijke Vorming. Enschede: SLO

Said, Edward W. (2004), Humanism and Democratic Criticism. New York: Columbia University Press

Scheffer, Paul, Sijbolt Noorda (2002), De hoogste burgerschool/Voor en tegen beter weten (opening of academic year at UvA 2002). Amsterdam: Amsterdam University Press

Scheffer, Paul (2005), Het verleden vergt onderhoud. (Ketelaarlezing 3) The Hague: Nationaal Archief

Schroots, Johannes and Maarten Langemeijer (2004), "Wie was Adolf Hitler ook alweer?", NRC Handelsblad 4 May 2004

Schuyt, C.J.M. (1998), Op academisch niveau: scholing en vorming in een gedifferentieerd stelsel van hoger en wetenschappelijk onderwijs. (Speech marking the opening of the academic year). Nijmegen: Pers \& Voorlichting KU

Schuyt, Kees (2005), De stuifzandsamenleving. Amsterdam: Meulenhoff

SCP (2004), In het zicht van de toekomst: Sociaal en Cultureel Rapport 2004. The Hague: Sociaal en Cultureel Planbureau Spiegelman, Art (1986/1991), Maus I. A Survivor's Tale and Maus II: And Here My Troubles Began. New York: Pantheon Press

Terwindt et al, J. (2003), Gebieden in perspectief: Natuur en samenleving, nabij en veraf. Voorstel voor nieuwe examenprogramma's aardrijkskunde in de tweede fase van havo en vwo. Utrecht: KNAG

Undervisnings Ministeriet (2006), Rapport fra Udvalget til styrkelse af historie i folkeskolen

Verhaal Centraal (2006), Verhaal Centraal: Spannende geschiedenis in woord en beeld. Een interdisciplinair project van zeven organisaties. Borger: privately published

Vos, J., J. van der Linden (2004), Waarvan akte: Geschiedenis van de MO-lerarenopleidingen, 1912-1987. Assen: Van Gorcum

Vries, Pieter Anko de (2006), Vaderlands verleden. Leeuwarden: Eudaimon 
Wagenaar, Henk, Frank van der Schoot, Bas Hemker (2003), Balans van het geschiedenisonderwijs aan het einde van de basisschool: Uitkomsten van de derde peiling in 2000. (PPON 23) Arnhem: CITO

Wagenaar, Henk, Frank van der Schoot (2004), Balans van de historische beeldvorming aan het einde van de basisschool: Uitkomsten van een peilingsonderzoek in 2000. (PPON 27) Arnhem: CITO

Wagenaar (ed.), H. (2002), Geschiedenis voor de basisschool: Een domeinbeschrijving als resultaat van een cultuurpedagogische discussie. Arnhem: CITO

Werf, Greetje van der (2006), "Maak een kern-curriculum voor alle scholen". [Paragraph 2 of an interview on the quality of education in the Netherlands] In: NRC Handelsblad M, September 2006, p. 26

Wesseling, H.L. (1998), "Bint en Boddens; de toekomst van de algemene ontwikkeling". In: H.L. Wesseling, Alles naar wens: Tien voordrachten over cultuur, geschiedenis en politiek. Amsterdam: Bert Bakker, p. 11-24

Wijnen et al, W.H.F.W. (2002), Verantwoording delen: Herziening van de kerndoelen basisonderwijs met het oog op beleidsruimte voor scholen. Advies van de commissie Kerndoelen Basisonderwijs. The Hague

Wilschut, Arie (2004), "Zinvolle en leerbare geschiedenis." In: Kleio 43 (April/May 2002) 3, p. 6-13

Wilschut, Arie, Dick van Straaten, Marcel van Riessen (2004), Geschiedenisdidactiek: Handboek voor de geschiedenisdocent. Bussum

Wilschut (ed.), Arie (2005), Zinvol, leerbaar, haalbaar: Over geschiedenisonderwijs en de rol van de canon daarin. Amsterdam: Vossiuspers UvA

Wilschut, Arie (2005a), "Canon of referentiekader? Over: "wat iedereen zou moeten weten van onze geschiedenis'. In: Didactief November 2005

Winter, Micha de, Thomas Schillemans, Rienk Janssens (ed.) (2006), Opvoeding in democratie. Amsterdam: SWP

Wit, J. de et al (1998), Het verleden in de toekomst: Advies van de commissie geschiedenisonderwijs. The Hague

[Zeeman, Michaël] (2002), Gouden Ganzenveer 2002: Michaël Zeeman. Amsterdam: Stichting de Gouden Ganzenveer

Zeeman, Michaël (2004), Nederlands Geestesmerk? De Lage Landen en hun zelfbewustzijn in hun posthistorisch heden (21ste Pacification lecture Ghent, 20 November 2004). Ghent: privately published 
APPENDIX 1

Letter of instruction 
Den Hoog Ons kenmerk

26 mei $2005 \quad$ ASEA/DIR/2005/23876

Onderwerp

Taakopdracht voor de commissie Ontwikkeling

Nederlandse Canon
Bijloge(n)

geen

De maotschappelijke ontwikkelingen van de laatste joren zijn aanleiding om opnieuw na te denken over de identiteit van Nederland en de wijze waarop deze tot uitdrukking komt in het onderwijs. Het begin van de $21^{\circ}$ eeuw lijkt een stroomversnelling in het proces van ontwikkeling van deze identiteit teweeg te brengen. Er lijkt in brede kringen behoefte te zijn aan een nieuw 'verhoal Nederland'.

Tegen deze achtergrond heeft de Onderwijsraad in zijn advies De stand van educatief Nederland ${ }^{1}$ mij geadviseerd de relevantie van het onderwijs voor de somenleving te versterken door te komen tot een canon voor het onderwijs. Het gaat hierbij volgens het advies van de Onderwijsraad om "die waardevolle onderdelen van onze geschiedenis die we via het onderwijs nieuwe generaties willen meegeven. ${ }^{m 2}$

Ik heb besloten dit advies op te volgen en geef hierbij, mede namens de beide staatssecretarissen, opdracht een canon voor het primair en voortgezet onderwijs (leeftijdsgroep vier tot achttien joar) te ontwikkelen. Ik verzoek u daarbij onderstaande voorwaarden in acht te nemen.

Ik zou het daarbij op prijs stellen als u uw voorstellen voor de Nederlandse conon in internationaal vergelijkend perspectief wilt stellen. Ik heb doortoe een (interne) overzichtsnotitie in voorbereiding die ik u binnenkort ter hand zal stellen. Daarmee kunnen we leren van ervaringen in het buitenland met een canon.

${ }^{1}$ Onderwijsraod. jonuari 2005.

${ }^{2}$ De stand van educotief Nederland, blz. 13

Ministerie von Onderwijs, Cultuur en Wetenschop

Rijnstroot 50, Postbus 16375,2500 BJ Den Hoog $\mathrm{T}+31-70-4123456 \mathrm{~F}+31-70-4123450 \mathrm{~W}$ www,minocw.nl

Contoctpersoon: P. Antenbrink, $\mathrm{T}+31-70-4122517$ 


\section{Doelstelling en functie}

In de discussie naar aanleiding van het Onderwijsraadadvies om een canon vast te stellen, worden nogal uiteenlopende doelstellingen en functies van een canon bepleit. Het is daarom van belang in deze opdracht doelstelling en functie zo precies mogelijk aan te geven.

Het gaat mij om een canon met als doel het bewerkstelligen van gedeelde (cultuur)historische kennis en daarnaast ook van bredere culturele en maatschappelijke kennis over Nederland in een internationale, vooral Europese context. Daarbij kunnen waardevolle onderdelen van onze geschiedenis' zowel betrekking hebben op positieve en negatieve aspecten daarin, aangezien beide hebben bijgedragen aan de vorming van de Nederlandse cultuur. Ook moet nadrukkelijk aandacht worden besteed aan de wijze waarop onze cultuur is en wordt beïnvloed door niet-Nederlandse culturen en omgekeerd.

De functie van een dergelijke canon is, zoals de Onderwijsraad aangeeft, drieledig. De kern ervan wordt door de minister van Onderwijs. Cultuur en Wetenschappen betrokken bij de kerndoelen en de examenprogramma's (zie ook onderdeel 2). De tweede, wijdere cirkel omvat elementen die scholen daarnoast ook nog in hun programma kunnen opnemen. De derde cirkel strekt verder dan het onderwijs en kan onder meer ouders, maatschappelijke en culturele instellingen, uitgevers en programmamakers voor allerlei media inspireren en tot oriëntatiekader dienen. Een concentrisch model lijkt me hier bij uitstek van toepassing.

Met een dergelijke canon wordt voor alle betrokkenen binnen en buiten het onderwijs richting gegeven aan hun activiteiten op dit gebied zodat deze elkaar kunnen versterken. Ik ben ervan overtuigd dat als jongeren in Nederland de kennis van tenminste de kern van de canon delen, dit burgerschapsvorming en integratie ten goede zal komen. Primair doel is echter de gedeelde kennis als zelfstandige waarde.

\section{Onderwijsinhoudelijke uitgangspunten}

Ook bij het vaststellen van een canon wil ik mijn bestuurlijke stelregels om scholen ruimte te bieden en het curriculum niet te overladen, recht doen. $\mathrm{Er}$ is recent veel werk verricht dat bij het opstellen van een canon voor het onderwijs uitgangspunt moet zijn. Het rapport van de Commissie Historische en Maatschappelijke Vorming o.I.v. de heer prof. dr. P. de Rooy uit 2001, vormt een uitstekend inhoudelijk uitgangspunt. De voorstellen van deze commissie zullen op het niveau van de regelgeving worden ingevoerd in 2005 (nieuwe kerndoelen primair onderwijs), 2006 (nieuwe kerndoelen onderbouw voortgezet onderwijs) en 2007 (nieuwe examenprogramma's havo/vwo). Aan de commissie wordt gevraagd deze kerndoelen te toetsen aan de doelstelling van de canon. Daarbij vraag ik in het bijzonder aandacht voor de kerndoelen voor PO en de onderbouw VO. Daarin wordt immers de voor iedere leerling verplichte basiskennis vastgelegd.

Het gaat mij zoals gezegd in de kern om historisch en cultureel besef. Daarvoor is enerzijds een bepaalde overzichtskennis noodzakelijk, woartoe ook behoort een relevant kader van feiten. Anderzijds echter moet een overdaad van op toetsing gericht onderwijs in feiten en namen zonder meer worden 
voorkomen omdat dat het vereiste overzicht en inzicht eerder schaadt en niet motiverend werkt. Een nieuw evenwicht daorin is de kern van de voorstellen van de hierboven genoemde commissie voor geschiedenis en dat nieuwe evenwicht is ook aan de orde bij andere culturele domeinen.

Mijn primaire verzoek is daarom om, gezien de in de regelgeving gekozen vorm, te bezien welke uitwerkingen dienstig kunnen zijn om scholen en ook buitenschoolse instellingen, bij de invoering van de nieuwe kerndoelen en examenprogramma's te ondersteunen op een zodanige wijze dat recht wordt gedaan aan de gedachte van een canon. Vervolgens moet die gedachte voorbeeldsgewijs uitgewerkt worden ook buiten het terrein van de geschiedenis, waarbij ik in het bijzonder denk aan de (breed opgevatte) domeinen van taal en literatuur, kunst, wetenschap. geografie, economie, techniek en geestelijke en maatschappelijke stromingen. Ook voor deze domeinen vormen de hiervoor genoemde kerndoelen en examenprogramma's van de relevante vakgebieden het uitgangspunt.

\section{Impact en verantwoordelijkheden}

Als minister van Onderwijs neem ik het initiatief tot het laten ontwikkelen van een canon. In die hoedanigheid ben ik direct verantwoordelijk voor kerndoelen en examenprogramma's voor het onderwijs. Scholen en leraren kunnen een belangrijke basis leggen voor het zich eigen maken van een canon maar zij kunnen dat niet alleen, daar zijn ook anderen voor nodig. Daarom moeten andere partijen in de samenleving in positie worden gebracht om het resultaat dat scholen kunnen behalen te versterken en aan te vullen. Het gaat er met andere woorden om dat de canon draagviak en reikwijdte krijgt in de hele samenleving.

Ik verzoek $\mathrm{u}$ om daarom ten tweede de verantwoordelijkheden en de verantwoordelijken binnen en buiten het onderwijs met betrekking tot de canon helder voor mij in kaart te brengen. In dit voorstel zouden in elk geval de instellingen die in het bereik van OCW liggen, aandacht moeten krijgen. In het bijzonder vraag ik u om rekening te houden met de ervaring die al is opgedaan in de samenwerking tussen onderwijs, wetenschap en cultuur. Daarbij speelt het samenwerkingsverband van verschillende instellingen op het terrein van geschiedenis en erfgoed. Anno genaamd, een centrale rol evenals het project Cultuur en School.

Andere instellingen en activiteiten buiten het onderwijs en mijn directe reikwijdte kunnen echter eveneens aan de succesvolle implementatie van de canon bijdragen. Het gaat er immers om ervoor te zorgen dat de canon beklijft en daarvoor kunnen ook instrumenten en actoren buiten de school worden benut. Bij bovengenoemde verantwoordelijkheidsverdeling is het dan ook van belang dat de commissie inzichtelijk maakt wie op welke wijze aan de inwerking van de canon een bijdrage kan leveren.

\section{De levensduur van een canon}

De vraag wélke onderdelen van historische en culturele kennis waardevol genoeg worden bevonden om aan volgende generaties te worden overgedragen, wordt in de loop van de tijd verschillend beantwoord. Opvattingen daarover kunnen al naar gelang de omstandigheden veranderen. De meningen zijn 
verdeeld ten aanzien van de houdbaarheid van een canon, moet die wel of niet periodiek worden geèvalueerd en gewijzigd? Mijn laatste verzoek is aan te geven of een dergelijk 'periodiek onderhoud' van de canon nodig is en zo ja, welke frequentie en evaluatieprocedure dan passend zijn.

\section{Werkwijze van de commissie}

Ik kies nadrukkelijk voor een commissie van inhoudelijk deskundigen om een canon op te stellen. Deze inhoudelijke deskundigheid betekent in dit geval zowel wetenschappelijke (domein-)kennis als kennis van de onderwijspraktijk. Het belangrijkste criterium is de pedagogisch-didactische haalbaarheid van de gemaakte keuzen. Dat betekent dat de commissie tijdens haar werkzaamheden voeling moet houden met belangrijke partijen. Dat geldt op de eerste plaats het onderwijs: de scholen, de leraren, de leerlingen. Het zou de effectiviteit van de canon niet ten goede komen als onvoldoende wordt aangesloten bij de werkelijkheid van alledag in de klaslokalen. Zoals hierboven geschetst stopt het daar echter niet. De wijze waarop de commissie haar voorstellen afstemt op wat onderwijskundig én praktisch haalbaar is voor de verschillende groepen van leerlingen, is een zaok van de commissie zelf. Maar ik vraag de commissieleden wel dat zij er verantwoording over afleggen in het eindrapport.

\section{Enkele praktische zaken}

Gezien het vele voorwerk en de gekozen inperking moet het opstellen van een canon nu op korte termijn mogelijk zijn. Ik verzoek de commissie om vóór 1 september 2006 haar werkzaamheden af te ronden.

De commissie levert een eindrapport op met, zoals in het voorafgaande aangegeven, als onderdelen:

- de canon zelf

- een advies over verantwoordelijkheden en verantwoordelijken op het gebied van de canon met een overzicht op welke wijze taken dienaangaande kunnen worden verdeeld

- een advies over frequentie en evaluatie/herziening van de canon.

Vóór 1 januari a.s. wordt een eerste tussenrapportage verwacht, waarover ik graag met u van gedachten wil wisselen. Dan kunnen we bezien of een tweede moment van tussentijds overleg nodig is alvorens de commissie het rapport afrondt.

Aan de commissie worden de kosten vergoed van een full time inhoudelijk en organisatorisch secretaris, aan te stellen in overleg met de voorzitter. Voor voorzitter en leden worden vacatiegelden beschikbaar gesteld en eventuele reiskosten vergoed.

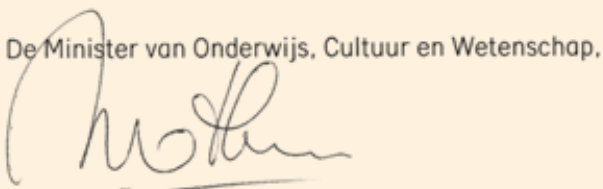

(Maria J.A. van der Hoeven) 
103 


\section{Composition of committee, description of working methods}

Frits van Oostrom (1953) is a University Professor in Utrecht; as of May 2005 he has also been President of the Royal Netherlands Academy of Arts and Sciences (KNAW). His specialisation is Dutch Medieval literature, and has published books on the subject that are both scientifically oriented and aimed at a broad audience. He was awarded the Spinoza Award for his scientific work in 1995; his book Maerlants wereld received the AKO literary award in 1996. His latest book, Stemmen op schrift: De Nederlandse literatuur vanaf het begin tot 1300 was published in February of 2006. This work is the first part of a major overview of Dutch literary history, written by nine experts.

\section{Vice-chairman}

Paul van Meenen (1956) is chairman of the board at Spinoza, a group of secondary schools in and around Leidschendam-Voorburg. After having studied mathematics at Leiden University, he worked as a teacher and manager in senior secondary and higher vocational education, and as a rector in secondary education. He is also chairman of the D66 party in the Municipal Council of Leiden.

\section{Members}

Herman Beliën (1946) works for the department of Recent History and American Studies at the Humanities Faculty of the UvA [Amsterdam University]. He specialises in Public History in the Netherlands and the US. Herman has published a number of books on this subject; De Notendop van de vaderlandse geschiedenis (2005 15th edition; in collaboration with M. van Hoogstraten) and Geschiedenis op Straat, Wandelen door historisch Nederland (2005; in collaboration with Paul Knevel and Ineke van Tol). 
Marjolijn Drenth von Februar (1963) is an essayist. After having completed studies in philosophy, art history and law, she published her debut novel, De zonen van het uitzicht, which was awarded the Multatuli Prize in 1990. She has written a thesis on the problems surrounding academic specialisation Een pruik van paardenhaar \& Over het lezen van een boek (2000) and has since focused on administrative and societal developments with regard to ethics, law and art. She writes a weekly column in de Volkskrant under the name Marjolijn Februari.

Frans Groot (1958) teaches history at the teachers training department of the Hogeschool Rotterdam, specialising in the period after 1500 . He obtained a doctorate in 1992 after having published his thesis Roomsen, rechtzinnigen en nieuwlichters: Verzuiling in een Hollandse plattelandsgemeente. Naaldwijk 1850-1930. He also published works on nation building in the Netherlands and helped develop the Sfinx. Geschiedenis voor de tweede fase teaching method. He is a member of the board at the Koninklijk Nederlands Historisch Genootschap [Royal Netherlands Historical Society].

Els Kloek (1952) is a senior professor/researcher at the history section of Utrecht University's Arts Faculty. She is currently working as project leader of the Digitaal Vrouwenlexicon van Nederland [Digital Women's Lexicon of the Netherlands] (www.vrouwenlexicon.nl), a joint project by the Research Institute for History and Culture (OGC) at Utrecht University and the Institute of Netherlands History (ING) in The Hague. She initiated and edited the popular science series Verloren Verleden (1998-2004, 24 volumes).

Susan Legêne (1955) is Head of Museums Affairs at the KIT Tropenmuseum. She also occupies an endowed chair in Cultural History of the Netherlands at the Universiteit van Amsterdam, specialising in the study of objects on behalf of the Royal Dutch Antiquarian Society. She is also a member of the National Unesco Committee. She publishes on the interface between (colonial) history and museology. Her thesis, De bagage van Blomhoff en Van Breugel - Japan, Java, Tripoli en Suriname in de negentiende-eeuwse Nederlandse cultuur van het imperialisme was published in 1998. She also wrote Partij in het verzet: De CPN in de tweede wereldoorlog in 1986, in collaboration with Hansje Galesloot. 
Rob van der Vaart (1951) is professor of Regional and Educational Geography at Utrecht University. He was closely involved in the revision of exam curricula for geography at HAVO and VWO level. He coordinates the NCDO master class Wereldburgerschap en Onderwijs [Cosmopolitanism and Education]. He also supervised dissertation research on the contribution of geography to general education and on geography and heritage tourism.

\section{Secretary}

Hubert Slings (1967) works at the arts faculty of Leiden University, specialising in (educational) policy advice, literature teaching methods and cultural education. He is also editor of www.literatuurgeschiedenis.nl, www.bijbelencultuur.nl and the school edition series Tekst in Context. In 2000, he obtained a doctorate on the basis of his thesis Toekomst voor de Middeleeuwen: Middelnederlandse literatuur in het voortgezet onderwijs.

\section{Working method}

The Committee for the Development of the Dutch Canon held fourteen plenary meetings over the course of the year. A number of smaller meetings were also held in order to prepare documents or consult with teachers. The committee also held a number of meetings on a plenary or en petit comité basis with various experts, interested parties and advisors (for an overview, see appendix 3).

At the start of its efforts, the committee launched the website www.canonvannederland.nl, which was visited well over 50,00o times during the past year, by more than 15,000 unique visitors. The focal point of the website was a revolving gallery of images and words that could be "rated" in terms of their canonical qualities. The site also featured information on the committee itself, its meeting schedule and a broad overview of its activities - this last facet was communicated through features such as a web log describing the committee members' experiences. The discussion forum was graced with 260 responses, in 65 topics. The quality of the comments was generally high.

In aid of its own meetings, the committee also had access to an internal debate forum, which allowed for the exchange of documents. The frequent use of email substantially reduced the need for meetings. 


\section{APPENDIX 3}

\section{Discussion partners and experts}

The list below is an overview of all the people the committee has spoken with (on a plenary or en petit comité basis) - either at our invitation or on their initiative, or who made any other contribution to this report. We would like to extend our gratitude to all consultative partners for their input, which provided us with a great deal of sustenance and inspiration.

\section{Our thanks go out to}

Paul Knevel for his editorial work on the fifty windows, in collaboration with Herman Beliën;

Rutger van Geelen for the photo editing;

Lia Reedijk from the Utrechtse Kinderboekhandel in Utrecht for helping us to take stock of children's literature in preparation for the fifty windows;

Gert Slings for correcting the manuscripts and Inge Slings-de Vries for correcting the proofs;

Arjan den Boer and Wessel Spoelder of ab-c media for designing and building the websites canonvannederland.nl and entoen.nu;

Nick Henning, Gerlanda Hoving, Maarten Handstede, Jeroen Hermkens, Johan Huijkman, Hannah Manneke, Philippe Wegner, Sietse Wolters and Arjan van Zeumeren of Eden Design for designing the wall chart and the screen design as well as various other contributions to entoen.nu;

Kok Korpershoek for the design of the committee logo and the layout and design of this report;

Livia Verstegen of Verstegen \& Stigter for helping to organise the presentation of this report;

Nico Schrijver and Joost Kloek for their expert contribution to several windows. 


\section{Our gratitude also goes out to}

Ron de Bruin, history teacher at Hogeschool Rotterdam PABO

Wouter Pols, staff member at Hogeschool Rotterdam PABO

Frank Meijer, Anno

Pieter de Dreu, Anno

Wim van der Weijden, Anno

Chris Groenevelt, Anno

Arie Wilschut, Instituut voor Geschiedenis Didactiek, Hogeschool Amsterdam

Frans Smits, Historisch Nieuwsblad

Linde van den Bosch, Taalunie

108

Karlijn Piek, Taalunie

Willemijn in 't Veld, Raad voor Cultuur

Peter Gramberg, Onderwijsraad

Peter Sigmond, Rijksmuseum

Kees Zandvliet, Rijksmuseum

Huub Kurstjens, CITO

Ronald Polak, CEVO

Jan Veldhuis, Profiles committee

Paul Schnabel, Profiles committee

Piet de Rooij, Profiles committee

Ireen van Ditshuyzen, Verleden van Nederland project

Geert Mak, Verleden van Nederland project

Gijsbert van Es, Verleden van Nederland project

Aad van der Want, managing director of Teleac/NOT

Klaas Clements, sector manager VMBO, CSG Goudse Waarden, Gouda

Remke Kruk, Leiden University, Arabic Faculty

Abraham de Swaan, Fundacion de Yuste

Koen Hilberdink, KNAW

Bertus Mulder, member of the provincial executive of Friesland

Tsjerk Bottema, staff member of the provincial executive of Friesland

Theo Witte, teacher trainer in Dutch Language and Literature at

Groningen University

Margreet Ruardi, Stichting Schrijver School Samenleving

Cor Geljon, retired Dutch language / Culture and the Arts teacher, Oegstgeest

Emiel Heijnen, subject teaching methods instructor at the Academy for

Visual Arts Education, Amsterdamse Hogeschool v/d Kunsten

Richard Hermans, Stichting Erfgoed Actueel

Floriëlle Ruepert, Stichting Erfgoed Actueel 
Cees Hageman, Stichting Erfgoed Actueel

Anton Korteweg, Letterkundig Museum

J. Pondaag, Komite Utang Kehormatan Belanda

Henk Wals, Huygens Instituut

Annemarie Kets-Vree, Huygens Instituut

Peter de Bruyn, Huygens Instituut

Sanne Wijnmalen, Beeldbank Beeld \& Geluid

John Leek, Beeldbank Beeld \& Geluid

Dick Schram, St. Lezen

Anne-Mariken Raukema, St. Lezen

Thije Adams, Boekmanstichting

Aspha Bijnaar, NiNSee, Amsterdam

Wim Manuhutu, managing director Moluks Historisch Museum, Utrecht

Bart Lubbers, News Photo

Bregtje Prent, News Photo

Mohamed El Aissati, chairman Maroc.nl

Metin Alkan, educational theory and educational studies teacher,

University of Amsterdam

Margot de Wit, Dutch section Vereniging van Leraren in Levende Talen

Patrick Rooijakkers, Dutch section Vereniging van Leraren in Levende Talen

Michiel Couzijn, Dutch section Vereniging van Leraren in Levende Talen

Conny Slingerland, teacher at 't Plein primary school, Rotterdam

Jana Bosman, primary school teacher, Amsterdam

Arend Jan Sleijster, primary school teacher, Zoeterwoude

Hans Keissen, PABO VGN committee

Theo Beker, PABO VGN committee

Cees van der Kooij, PABO VGN

Maria Boersen, PABO VGN committee

Henk Pröpper, Nederlands Literair Productie- en Vertalingenfonds

Leonoor Broeder, Nederlands Literair Productie- en Vertalingenfonds

Raymond Kreek, history teacher at Farelcollege, Ridderkerk

Irene Oskam, history teacher at GSG Helenium, Hellevoetsluis

Timo Liefting, history teacher at CSG De Goudse Waarden, Gouda

Jan Jaap Knol, Culture \& School

Jelle Jolles, professor of neurocognition, Maastricht University

Ankie Verlaan, Hogeschool/Universiteit van Amsterdam

Various staff members of the Ministry of Education, Culture and Science

(OCW) 


\section{Abbreviations}

ANP Netherlands National News Agency (Algemeen Nederlands Persbureau)

BIO Education Professions Act (Wet Beroepen in het Onderwijs)

110

CEVO Central Exam Content Board (Centrale examencommissie vaststelling opgaven)

CITO National Institute for Educational Measurement (Centraal Instituut voor Toetsontwikkeling)

CPB Netherlands Bureau for Economic Policy Analysis (Centraal Plan Bureau)

CVEN Exam Standards Renewal Committee (Commissie Vernieuwing Eindexamennormen Nederlands)

CKV Culture and Art (Culturele en Kunstzinnige Vorming)

dbnl Digital Library of Dutch Literature (Digitale Bibliotheek voor de Nederlandse Letteren)

HBO Higher Vocational Education (Hoger Beroepsonderwijs)

OCW Ministry of Education, Culture and Science (Onderwijs, Cultuur en Wetenschap)

PABO Teacher Training Academy for Primary Education (Pedagogische Academie voor Basisonderwijs)

PO Primary Education (Primair Onderwijs)

SLO National Institute for Curriculum Development (Stichting Leerplan Ontwikkeling)

VMBO Pre-Vocational Secondary Education (Voorbereidend Middelbaar Beroepsonderwijs)

VO Secondary Education (Voortgezet Onderwijs)

VSNU Association of Dutch Universities (Vereniging van Samenwerkende Universiteiten in Nederland) 


Section B 


\section{Introduction}

This second section of the report contains a further elaboration of the canon and an overview of the key facts of Dutch history that served as a guideline for selecting the components of the canon.

The canon was designed in line with the structure of the entoen.nu website. The first layer comprises fifty icons, each with a short story that illustrates the significance of the relevant component of the canon. The icon and this main text are on the left page.

On the right page, the canon window opens out as it were, to offer insight into the possibilities for expansion in the education sector. These are the so-called Sub-topics. First, suggestions for related subjects are listed for the primary education sector. The preference of the committee in this respect lies with storyline topics. Following on from this, suggestions for themes for the secondary education sector can be selected to widen or deepen the view from the window.

A further two sub-categories follow: Past and Present and In the Treasure Chest. The former contains suggestions for comparisons between the past and the present, the latter for what could be placed in a treasure chest to make the past tangible, as it were.

The final section, References, contains further information on the subject. The category Places to Go lists possible excursions and is followed by references to relevant books for young people, background literature and informative websites. Short texts have been used wherever possible as the internet allows easy access to more complete background information. 
In the printed version presented here, the windows on the right page offer just

the initial contours. However, in the website to be developed for the canon, the Sub-topics and References sections will be elaborated in much greater detail. To reiterate: you will find the canon in its true form at www.entoen.nu. 


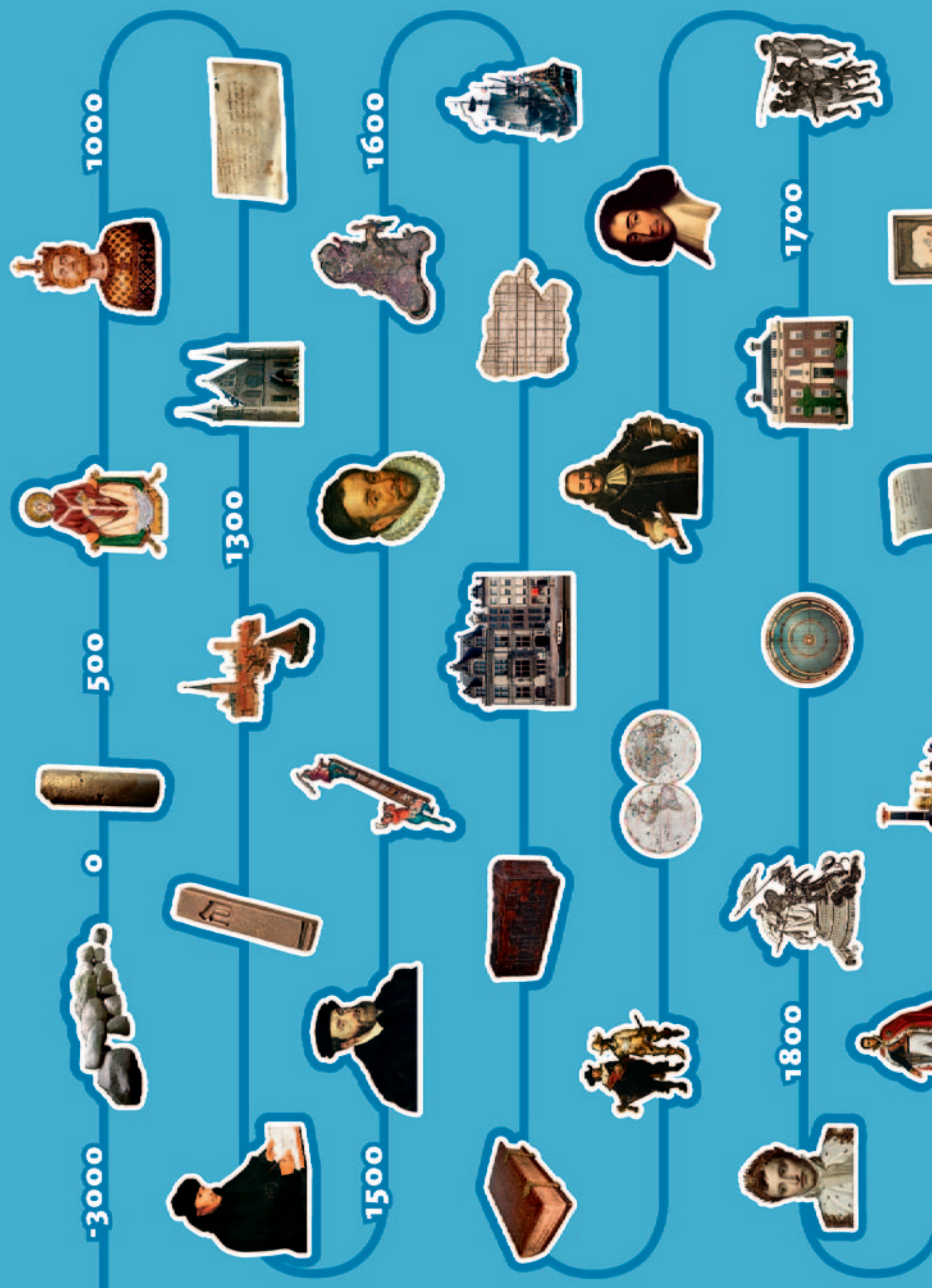




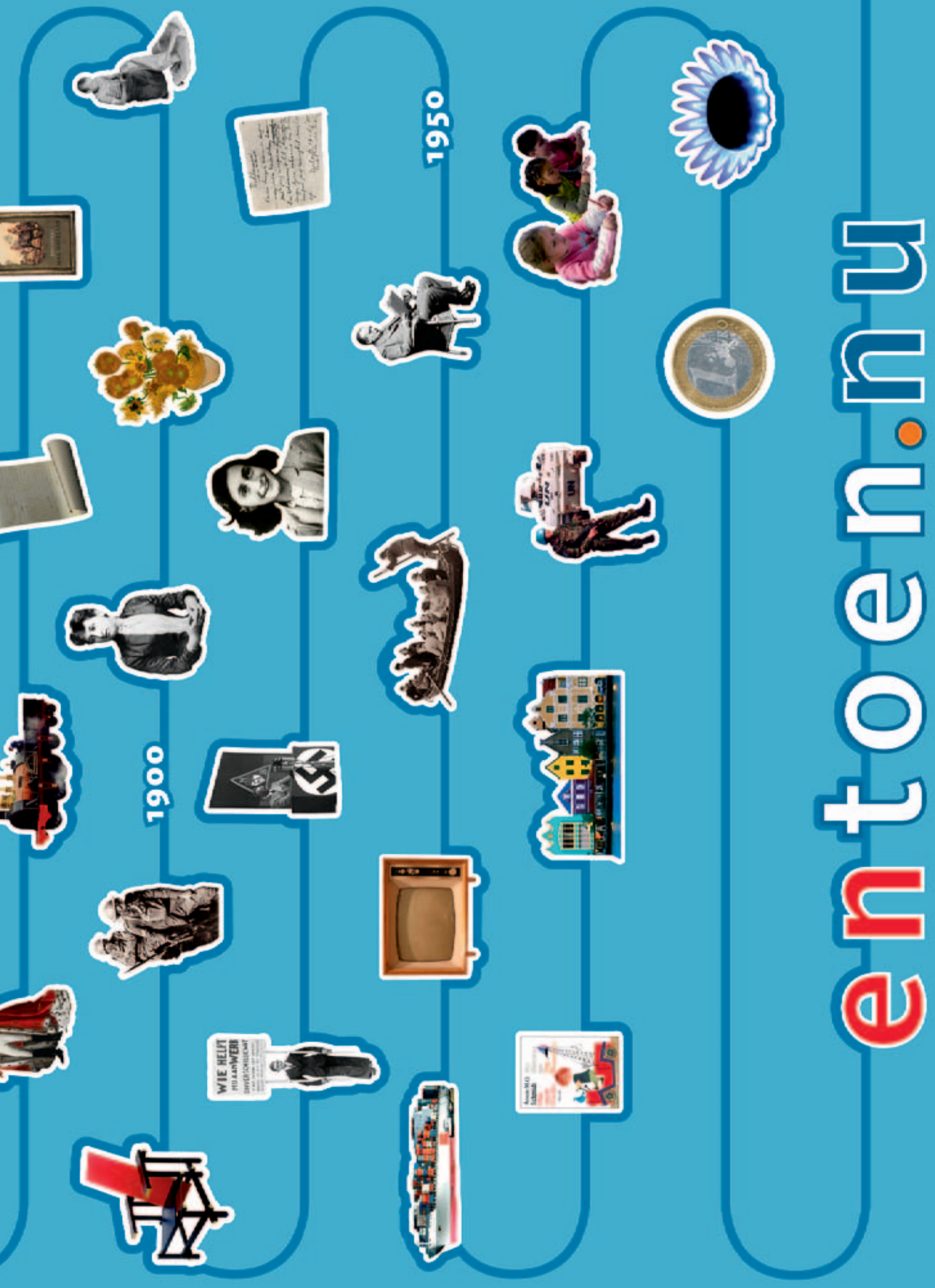




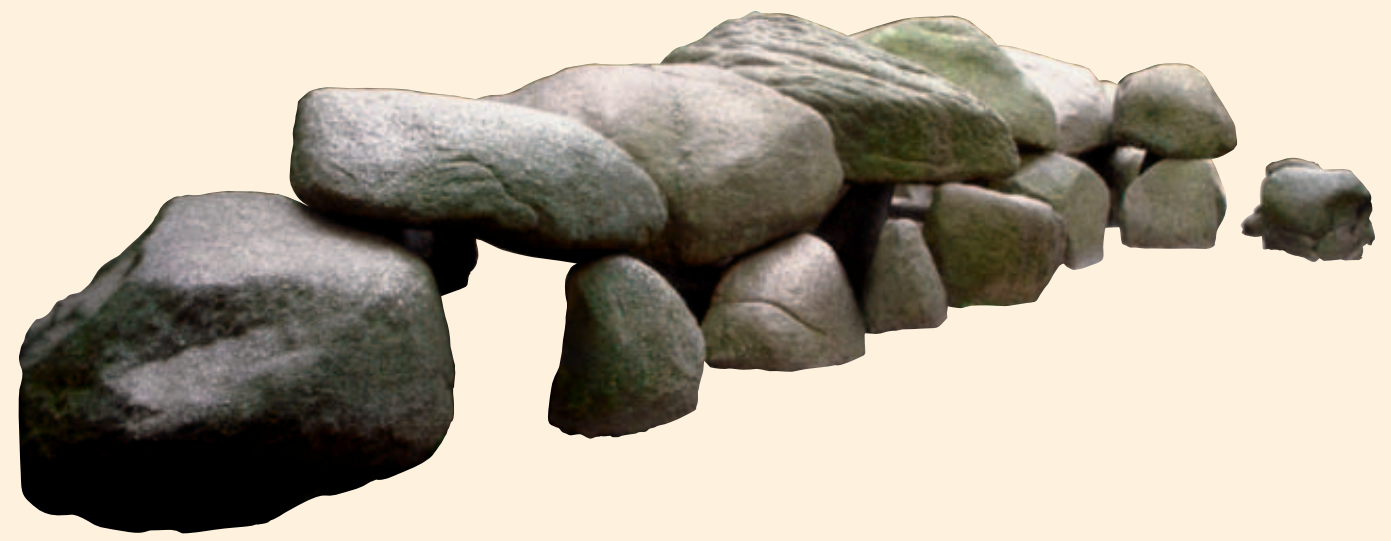

\section{circa $3000 \mathrm{BC}$ Megalithic tombs}

\section{Early farmers}

People were already living in the Low Countries when the world was five thousand years younger than it is today. What little they left behind is usually buried deep in the ground. However, in the province of Drenthe, you can see traces of them above the ground. Their megaliths: giant stones that people set in formations and piled up on one another. They were used as tombs. This type of chamber tomb was relatively common at the time, but certainly not all such tombs were built with enormous erratic blocks. These huge boulders were only to be found in Drenthe, Denmark and northern Germany and must have been transported there by glaciers during one of the ice ages some 150,000 years ago.

Archaeological excavations in and around megalithic tombs have not uncovered any skeletons - bones have completely disintegrated after so many thousands of years - but funerary gifts placed with the deceased for use in the afterlife have been found. These gifts include pots known as "funnel beakers" due to their shape. Based on these and other finds, archaeologists have constructed a picture of the way of life of these first generations of farmers. They were the first people in the region to leave behind their hunter-gatherer existence and settle in a fixed place. They lived in wattle and daub farmhouses, used wooden and stone tools and made pots for storage. Undoubtedly they also made agreements regarding ownership and the administration of justice, but we can no longer discover what these were because these early farmers had no written language. Their society had no written records.

How these people were able to raise stones from the ground that sometimes weighed 20,000 kilos, without any machinery, 
is still not completely clear. Perhaps they built earthen ramps and used small logs to roll the stones. Once the stones were in place, the ground underneath them could have been dug away to create a chamber tomb.
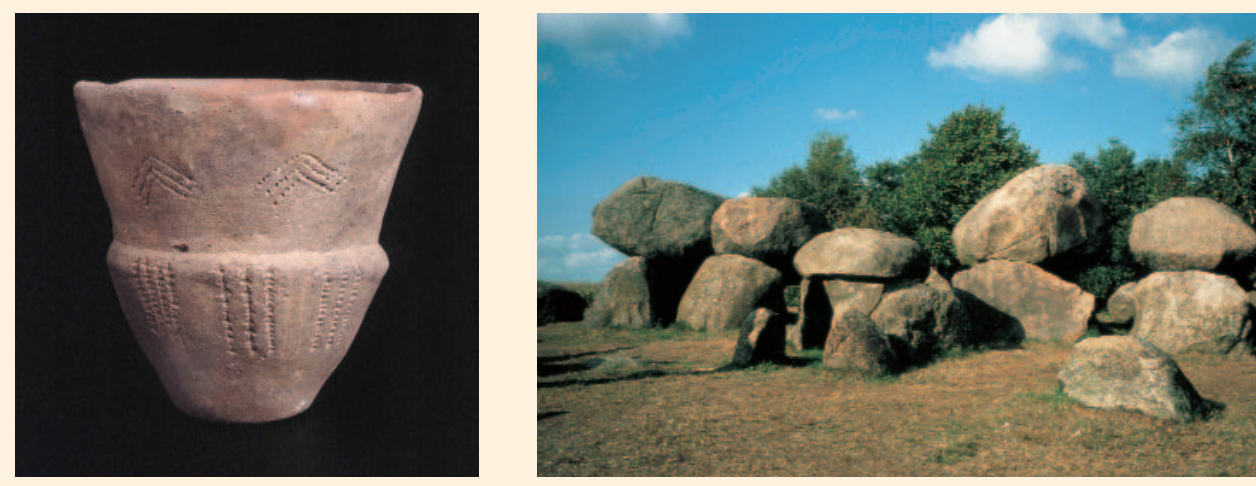

\section{Sub-topics}

\section{Primary education sector}

The way of life of hunter-gatherers

The emergence of farming and agricultural societies Bog bodies (Yde Girl)

\section{Secondary education sector}

The difference between the way of life of hunter-

gatherers and the earliest farmers in the Middle East Archaeology

Famous Stone Age monuments: Stonehenge, Carnac Geological development of the Netherlands Archaeological forgeries (the story of Tjerk Vermaning)

\section{Past and Present}

What do funeral rites tell us about a culture? (cf. the discussion about burial vs. cremation)

\section{In the Treasure chest}

Hand axe

Funnel beaker
In Drenthe, over fifty megalithic tombs have remained preserved. There must have been many more at one time, because over the centuries a great many megaliths have disappeared, for instance, because the stones were used for building.

\section{References}

Places to Go

Borger: Hunebedcentrum Borger

Assen: Drents Museum (Yde Girl)

Alphen aan den Rijn: Archeon

\section{Books for young people}

Bart Römer, De veenheks

Peter Smit, De vlucht van Lodi

Roelof Wijtsma and Frans Le Roux, Arin en het volk van de hunebedbouwers (series of cartoon books, of which two issues have already been published)

\section{Background literature}

L.P.L. Kooijmans (editor), Nederland in de prehistorie, Amsterdam 2005.

\section{Websites}

www.hunebedcentrum.nl www.hunebedden.nl www.archeologienet.nl/tijds_periode/index.htm 


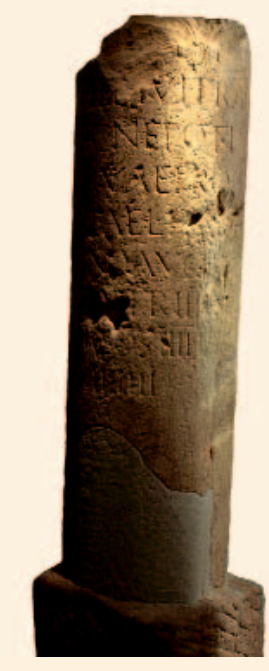

\section{AD - circa 400 AD The Roman Limes}

\section{On the frontiers of the Roman world}

Two thousand years ago, one of the frontiers of the immense Roman Empire ran through the Low Countries. The River Rhine that flowed from Nijmegen via Utrecht and Alphen aan den Rijn to the sea at Katwijk, formed part of the Roman Limes, the Latin word for frontier. In the eyes of the Romans, the uncivilised world began north of the river. That was where Germanic and Celtic tribes lived, including the Frisians and the Canninefates. The Rhine was, however, not just a frontier. It was also a major transport channel for the Romans. Supplies were brought in and exported by ship.

The Romans built watchtowers and army camps at regular intervals along the Rhine to defend their territory against enemy attacks from the north. Most of the encampments could house several hundred soldiers, but close to Nijmegen a camp arose that could accommodate two legions of six thousand men. The presence of these well-trained soldiers in their tunics, with their shiny helmets, shields and swords, must have made quite an impression on the local population. Moreover, the surrounding areas changed dramatically with the introduction of Roman architecture.

South of the frontier - in Roman territory - lived, among others, the Batavians. They lived in peace with the Romans and many Batavians served in the Roman army. However, in 69 A.D. they rose up against the Romans, profiting from the unrest that had broken out across the entire Roman Empire following the death of the Emperor Nero. The Batavians were led by Julius Civilis, a Batavian who had already served twenty-five years in the Roman army. For a short time it seemed as if the rebellion would be successful, but after a few months the Romans defeated the Batavians. Julius Civilis had achieved nothing. Nonetheless, he was honoured as a true hero centuries later. Sixteenth century scholars claimed that the Batavians had rebelled for love of freedom 
and that they should therefore be regarded as the true forefathers of the Dutch. This says more about the scholars than it does about the Batavians.

In the fourth century AD, more and more Germanic tribes invaded Roman territory. As a result, the Romans ultimately withdrew to behind the Alps.
Various places along the Rhine in the Netherlands have their origins in Roman times, as you can see on a medieval copy of an ancient Roman map. Finds are still being made at new archaeological excavations. For example, a watchtower and two ships were unearthed when the new Leidsche Rijn district was being built near Utrecht.

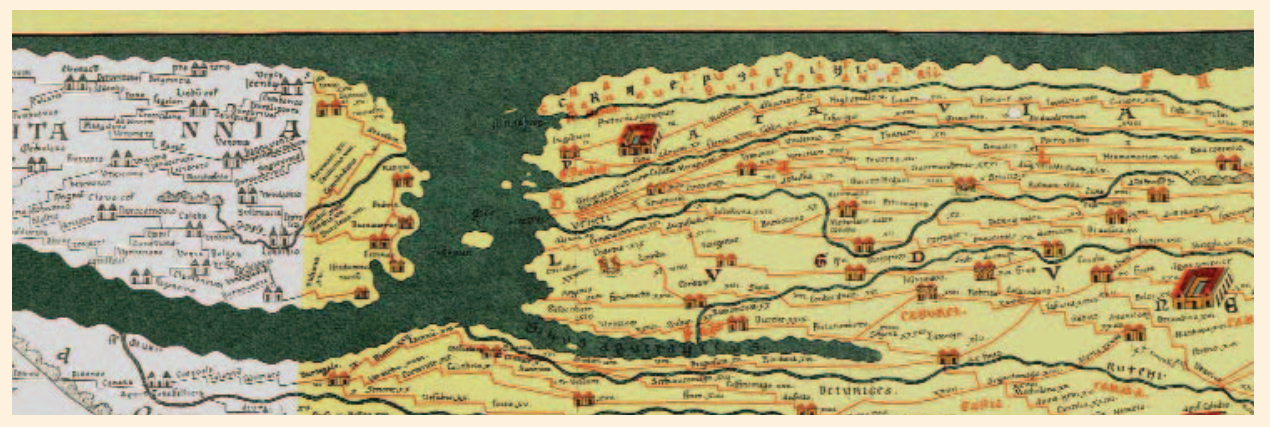

\section{Sub-topics}

\section{Primary education sector}

The conquests of Julius Caesar

Nijmegen in Roman times

The river as a frontier and transport channel

\section{Secondary education sector}

The Batavian rebellion

Trade and cities in Roman times

Frontier cultures: the confrontation between the Germanic and Roman cultures

Roman writers on the Germanic tribes

How the Roman Empire was organised

\section{Past and Present}

Roman remains in the Netherlands Archaeology in the Netherlands

Are there similarities between ancient Rome and the modern United States as a super power?

\section{In the Treasure chest}

Roman helmet

\section{References}

Places to Go

Alphen aan den Rijn: Archeon Nijmegen: Valkhof Museum Xanten: "Römerroute" Lelystad: Batavia Shipyard, where a Roman ship discovered at Leidsche Rijn is on show

Books for young people

Thijs Goverde, Het bloed van de verraders $\left(9^{+}\right)$ Martine Letterie, Het jaar van de Bataafse opstand (9+) Jan Ploeger, Het loge huis (12+)

\section{Background literature}

Hans Teitler, De opstand der "Batovieren", (Verloren Verleden 1), Hilversum 1998. Bernard Colenbrander (ed.), Limes Atlas, Rotterdam 2005.

\section{Websites}

www.limes.nl

www.cultuurwijzer.nl/cultuurwijzer.nl/cultuurwijzer.nl/ io00437.html (medieval copy of a map of the Roman world at the time of Emperor Augustus) www.museumvalkhof.nl/indexz.html (computer animation of the headquarters of the Roman army encampment near Nijmegen) www.roemerroute.de www.belvedere.nu www.archfonds.nl 


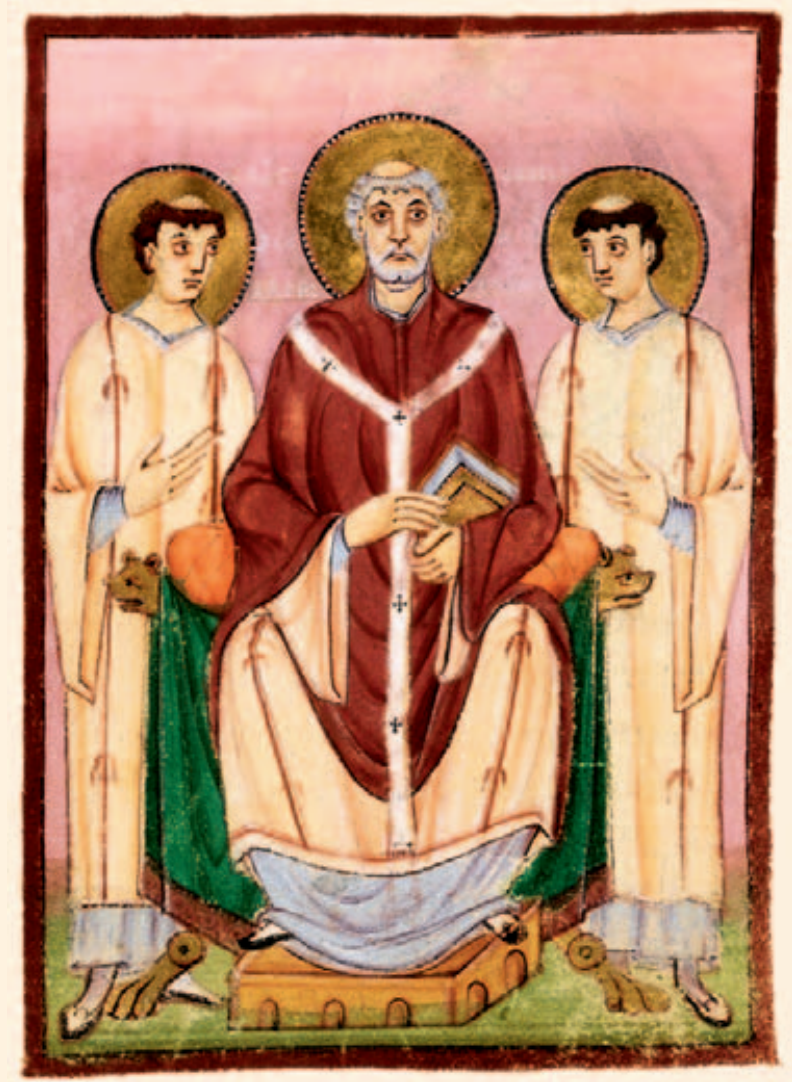

\section{AD - 739 AD \\ Willibrord}

\section{The spread of Christianity}

In $690 \mathrm{AD}$, Willibrord, an English monk from Northumbria, landed at the then mouth of the Rhine where the town of Katwijk is now situated. Together with a group of colleagues he wished to spread Christianity throughout the land of the Frisians. The Frisians lived in the coastal region stretching from the Westerschelde to near Dokkum. Their territory bordered on that of the Frankish kings, who had converted to the Christian faith a century earlier. The port town of Dorestad aan de Rijn and the settlement of Utrecht were situated on the border. This was not a permanent border, because battles regularly broke out and the border would shift as the Frisians moved slightly to the south or the Franks to the north. During a period of success, in $630 \mathrm{AD}$ a Frankish king had built the first church in Utrecht at the place where the Dom now stands. Shortly afterwards, however, the church had been destroyed by the Frisians.

Willibrord's predecessors had experienced that converting the heathen Frisians would be no easy task. For this reason, Willibrord first sought support. He paid several visits to 
the Frankish king and the Pope in Rome. The latter appointed Willbrord Archbishop of the Frisians. In $696 \mathrm{AD}$, Willibrord settled in Utrecht. He rebuilt the church destroyed earlier by the Frisians and commissioned the building of a new church dedicated to San Salvator, or, in other words, Jesus Christ.

Subsequently, missionaries left Utrecht for the lands of the Frisians. They were successful and by the end of Willibrord's life
- he died in $739 \mathrm{AD}$ - the new faith had the upper hand in the coastal region. In the rest of Frisian territory, however, resistance to the new faith was strong. The local nobility regarded the missionaries as accomplices of the Franks and they clung to the old ways and their gods like Wodan and Donar. It was only at the end of the eighth century AD that Frankish weapons finally crushed the Frisian resistance.

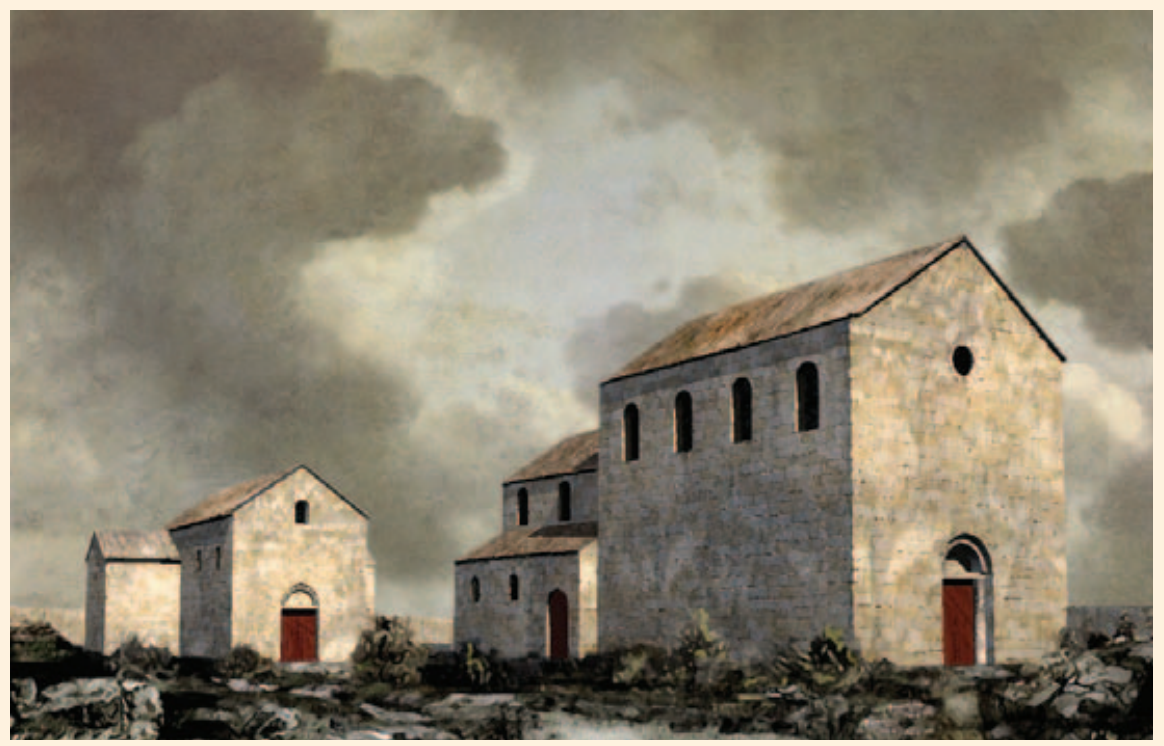

\section{Sub-topics}

\section{Primary education sector}

The life and death of Boniface

Ancient Friesland

The history of Dorestad

\section{Secondary education sector}

The early development of the town of Utrecht The religion of the Frisians

The English missionaries

The Pope, Bishop of Rome

The early spread of Christianity

\section{Past and Present}

Religious missionary work across the world, for different religions, then and now

\section{References}

Places to Go

Utrecht: Catharijneconvent Utrecht: Cross of churches Dokkum: Boniface's well

\section{Books for young people}

Akky van der Veer, Bonifotius en zijn tijd

\section{Background literature}

Joris van Eijnatten and Fred van Lieburg,

Nederlandse religiegeschiedenis, Hilversum 2005.

\section{Websites}

www.collectieutrecht.nl/view.asp?type=thema\&id=33

In the Treasure chest

A crucifix 


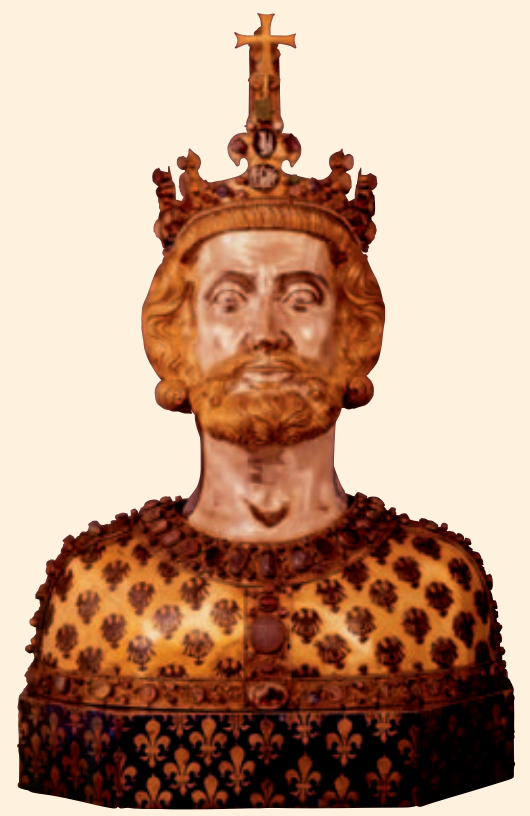

\section{AD - 814 AD Charlemagne} Emperor of the Land of the Setting Sun

Charlemagne was the most important king of the early Middle Ages. In $771 \mathrm{AD}$ he became King of the Franks, whose territory included what would be the Low Countries. Charlemagne was at war throughout his entire reign: against the Moslem rulers of the Iberian peninsula, against the Langobards in the south and against the Saxons and the Danes in north-western Europe. Charlemagne was successful because he managed to expand the kingdom of the Franks into an empire that encompassed large parts of what we know today as Europe. On Christmas day $800 \mathrm{AD}$, the Pope crowned Charlemagne Emperor of the West.

To govern his enormous empire, Charlemagne used "vassals" or liegemen who had to serve him "in word and deed". They had to advise him on all kinds of administrative matters and serve him as warriors in times of war. In exchange, they received a "fief" from Charlemagne, control over and the revenues of a large area of land. The vassals in turn often divided their land among tenants. Initially, the agreements terminated on the death of the vassal, but over the course of time the vassals began to regard their fiefs as hereditary possessions and adopted an increasingly independent position in respect of their liege lord.

Charlemagne kept palaces throughout his empire. Such a palace was known as a "palts". Charlemagne travelled from palts to palts arranging his affairs with his vassals on the spot. He also had a palts in Nijmegen: the Valkhof. Here, Charlemagne busied himself, among other things, with the situation in the Frisian bishopric and kept abreast of the campaign of his armies against the heathen Saxons. Charlemagne's first 
biographer, the monk Einhard, regarded this 33-year-long battle as the "longest, most horrible, and, for the Frankish people, the most exacting war he ever waged".

Charlemagne set great store by education, culture and science. Although he himself could barely write his own name, he was accomplished in maths and astronomy and he spoke several languages. Charlemagne established schools to train young noblemen for serving the empire. He also was in contact with the Moslem world through the Caliph of Baghdad, Harun al-Rashid, who gave him an elephant as a gift.

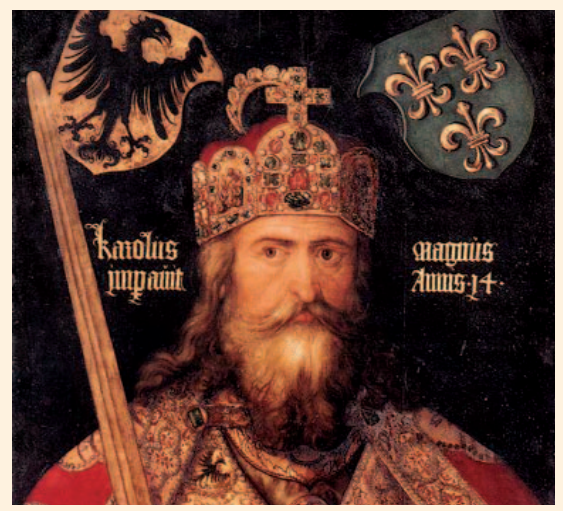

\section{Sub-topics}

\section{Primary education sector}

Charlemagne crowned Emperor (800 AD)

Einhard: the first biographer of Charlemagne

Knight's Tales: Charlemagne and Elegast, Song of Roland, Haymon's Four Children

\section{Secondary education sector}

Liege lords and vassals

The "Carolingian Renaissance"

The tradition of Chanson de Roland:

Charlemagne in literature

Charlemagne and Islam

Charlemagne and the Pope

\section{Past and Present}

Charlemagne and the importance of education

Contemporary tales of heroes

In the Treasure chest

Small statue of Charlemagne on his horse
In the last years of his life, Charlemagne settled down in his palace complex at Aix-enChapelle, where he was buried in $814 \mathrm{AD}$. His palace chapel formed the basis for the present Cathedral (the Dom), where his throne and elaborately-decorated coffin can still be seen today.

Even in his own lifetime, many stories went around about Charlemagne. After his death they became even more expansive and embellished; people started to regard him as a saint. Charlemagne is considered one of the greatest kings in history.

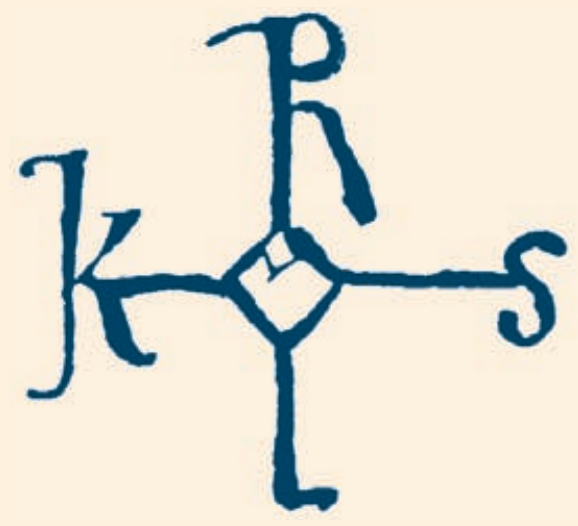

\section{References}

Places to Go

Aix-en-Chapelle: Dom, treasure chamber Nijmegen: The Valkhof

\section{Books for young people}

Agave Kruijssen, Elegast (10+)

Agave Kruijssen, Razende Roeland, een ware held (10+)

\section{Background literature}

Marco Mostert, "Karel de Grote (747-814)"

in Els Kloek (ed.), Verzomeld verleden:

Veertig gedenkwaordige momenten en figuren

uit de vaderlandse geschiedenis, Hilversum 2004

\section{Websites}

geschiedenis.vpro.nl/dossiers/28891110

(with lovely audio/video clips from programs)

users.pandora.be/vroege-middeleeuwen/karelgr.htm 


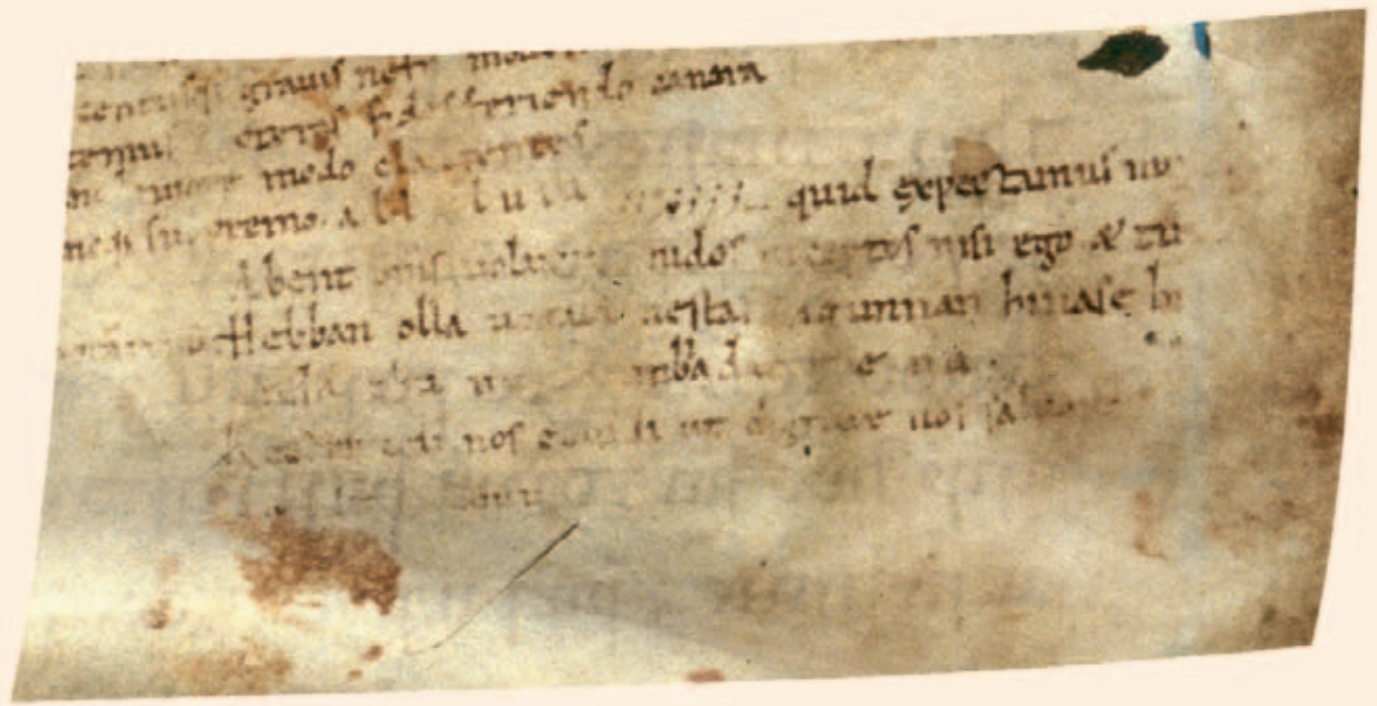

\section{circa 1100 \\ Hebban olla vogala \\ The Dutch language in writing}

Hebban olla vogala nestas hagunnan hinase hic anda thu, wat unbidan we nu?

The above is a Dutch sentence, although at first sight it's barely recognisable as such. This is because it is about the earliest piece of written Dutch we have, some one thousand years old. It literally says: Have all birds nests started except me and you; what wait we for, or: All birds have started making nests, except you and me, what are we waiting for? These lines are probably from a love song, the oldest Dutch love song you could say.

These lines were written to test a quill pen in about 1100 by a Flemish monk who was staying in an English monastery. His daily life was largely filled with copying Latin and old English texts. Now and then he had to sharpen the goose quill he used for writing. On the last page of the book he was copying he would try out his newly sharpened pen before continuing his copying. In such instances he wrote the first thing that came into his head. For this monk, it was a love poem that he remembered from his youth in Flanders: Hebban olla vogala...

This was simply an incident that only with the wisdom of many centuries could be regarded as the beginning of a new phenomenon: the use of the Dutch language as a medium for written literature. That the first fruits of the pen in Dutch were written in a monastery and were preserved in a sacred monastic book is, of course, no coincidence. Writing had long been the domain of monks and the written word was mainly used for the sacred, Latin texts of the church. 


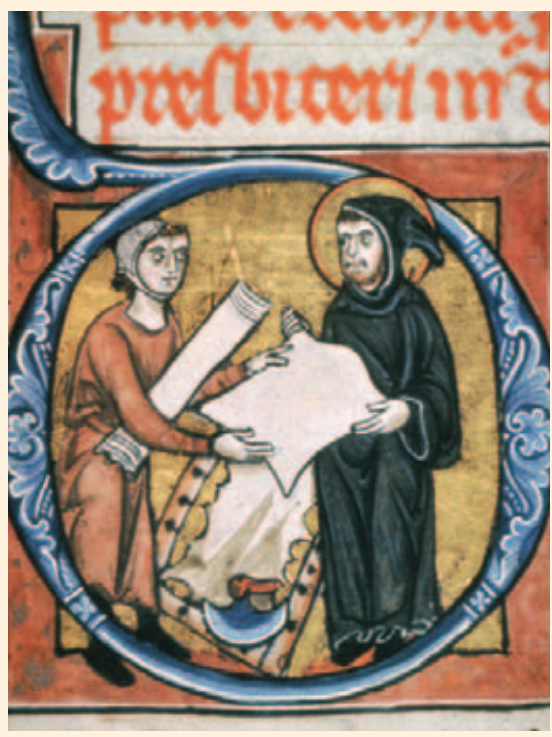

Sub-topics

\section{Primary education sector}

Writing then and now

Language families (similarities between and

differences in languages)

Love songs

\section{Secondary education sector}

Monastic orders

Middle Dutch literature at a glance

Medieval love poetry (Lied van Heer Halewijn,

Egidiuslied, Aloëtte, Twee koningskinderen)

Arab culture as a breeding ground

Language families

\section{Past and Present}

What is the impact of modern media like computers and text messaging on language?

Contemporary love songs (Is the imagery in

"Hebban olla vogala" outdated or not?)

In the Treasure chest

Goose quill pen, bottle of ink and a piece of parchment

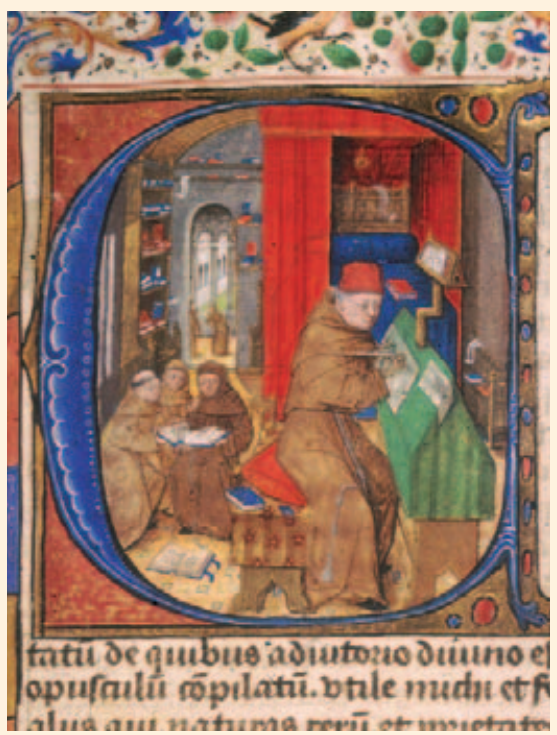

\section{References}

\section{Places to Go}

The Hague: Meermanno Museum (in the scriptorium you can try writing with a goose quill pen)

Zutphen: Librije, medieval library

\section{Books for young people}

Martine Letterie, Focke en de belegerde stad

(from chapter 7 on)

Agave Kruijssen, Lancelot (10+)

Agave Kruijssen, Merlijn (10+)

Agave Kruijssen, 't Ros Beiaard (10+)

Agave Kruijssen, Vrije val (Beatriis) (10+)

Agave Kruijssen, Walewein, ridder van de Ronde Tafel (10+)

Paul Biegel, Reinaart de vos (12+)

Paul Biegel, Anderland, een Brandaan-mythe (14+)

Joke van Leeuwen, Waarom een buitenboordmotor eenzoam is... (info)

Katharina Smeyers, Schapenvellen en ganzenveren. Het verhaal van het middeleeuwse boek (info)

\section{Background literature}

Frits van 0ostrom, Stemmen op schrift: Geschiedenis van de Nederlandse literatuur vanaf het begin tot 1300, Amsterdam 2006, pp. 93-107.

Jan W. de Vries, Roland Willemyns, Peter Burger, Het verhaal van een taal: Negen eeuwen Nederlands, Amsterdam 2003.

\section{Websites}

www.literatuurgeschiedenis.nl

www.dbnl.org 


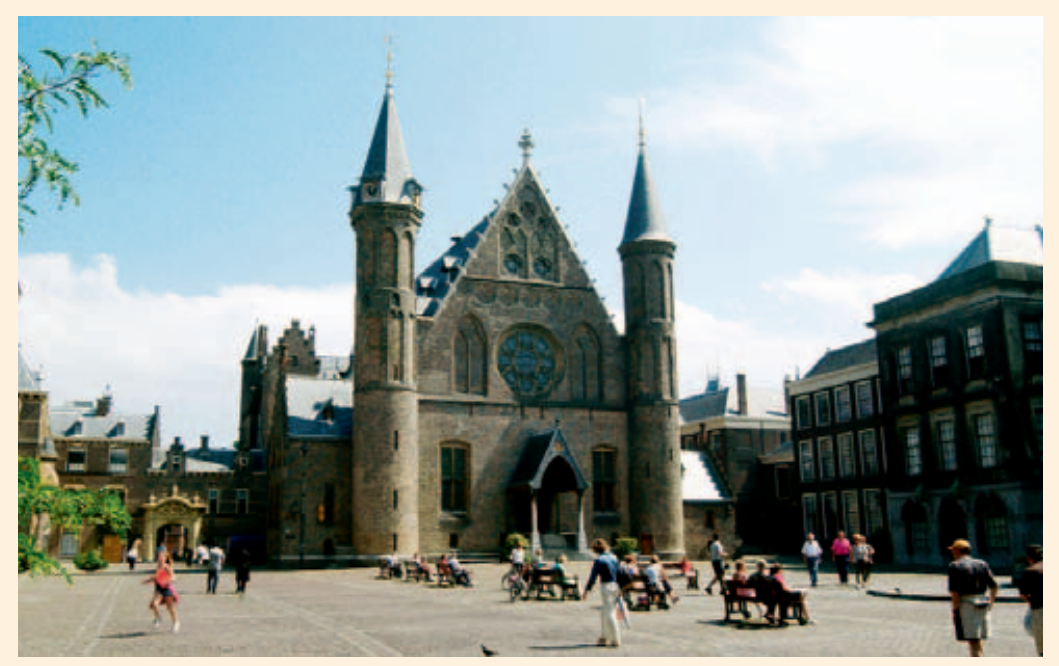

\section{$1254-1296$ \\ Floris V}

\section{A Dutch count and disgruntled nobles}

Today, the "Binnenhof" is symbolic of the Dutch political scene that has its home in The Hague. Few people realise that the history of the complex goes back to the thirteenth century and is closely linked to the period in which the most famous medieval Count of Holland, Floris V, ruled. When Floris was born in the summer of 1254, a new castle was being built in des Graven Haghe (The Hague). Floris's father, Count William II had commissioned the building. In 1256, during an expedition against the Frisians near Hoogwoud, Count William and his horse fell through the ice. The Frisians were quick to rush up and smash in his skull. At only two years old, Floris was now officially the new count, although power was temporarily vested in the hands of his uncle.

Once he gained his majority, Floris decided to avenge his father's death by conquering the Frisians. The campaign was a huge failure and allowed the peasants and town-dwellers in Kennemerland the opportunity to rebel. Floris was only able to quell the rebellion by granting Kennemerland a number of privileges that would afford the inhabitants protection from the noble lords. The indignant nobles sneeringly called Floris: "Der keerlen god", the god of the peasants.

In the years that followed, however, Floris was able to expand the territory of the counts of Holland considerably: he snatched the Amstel region and Woerden from the Bishop of Utrecht (thereby making the very young Amsterdam a town of Holland) and he conquered West Friesland. To consolidate his victories, Floris had citadels built near Alkmaar, Medemblik and Wijdenes.

In about 1280, the new castle in The Hague was finally completed with its proud Great Hall (literally the Knight's Hall, Ridderzaal), symbol of chivalry, regal and imposing in style as Floris had desired. Floris had a second castle built: Muider Castle (Muiderslot). 
In 1296, Floris' rebellious vassals Gijsbrecht van Amstel, Gerard van Velzen and Herman van Woerden took him prisoner in Muider Castle. The peasant population trekked to the castle to demand the release of their count. The three conspirators fled the castle

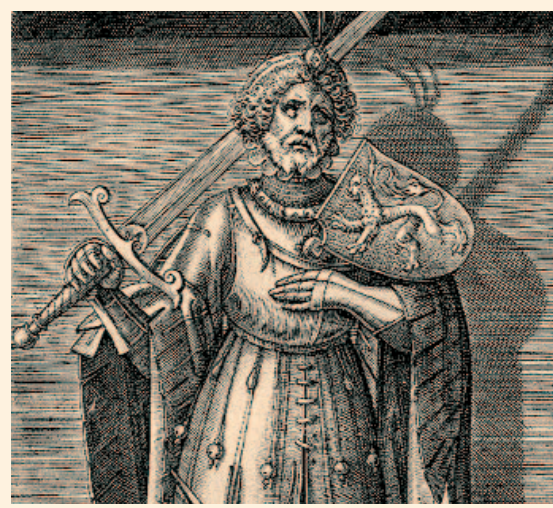

\section{Sub-topics}

\section{Primary education sector}

The age of chivalry (fighting, but falconry as well) The Hague as a court-capital

The campaign of Count William II against the Frisians

(1256) \& the discovery of the body of William II by Floris $\mathrm{V}(1282)$

\section{Secondary education sector}

Gijsbrecht van Aemstel

Waging war in the Middle Ages

Floris $\mathrm{V}$ as a ruler caught between the nobility and the townfolk

The murder of Floris $\mathrm{V}$ in literature

Floris $\mathrm{V}$ and the dominion of the Counts of Holland contested by England and France

\section{Past and Present}

How has the Great Hall been used over the centuries? Prinsjesdag (Prince's Day): politics then and now

\section{In the Treasure chest}

A pair of knight's spurs with their prisoner, in the hope of escaping the angry peasant mob. They had tied Floris' legs together under his horse's belly and when he tried to escape he ended up in a ditch where his captors slashed him to death with their swords.

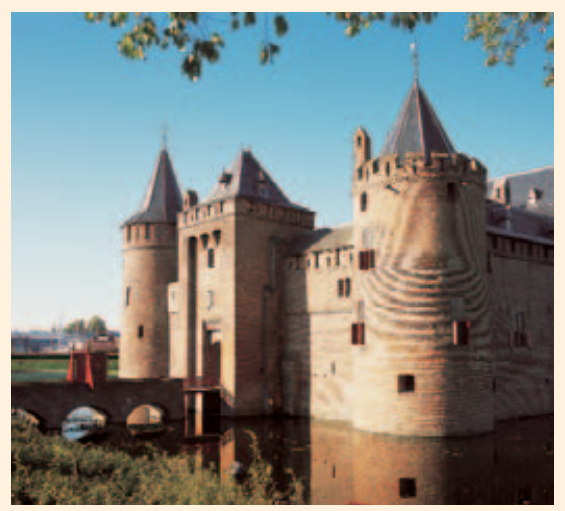

\section{References}

\section{Places to Go}

The Hague: the Binnenhof Muiden: Muider Castle (including falconer)

\section{Books for young people}

Arend van Dam, Schildknaop op het Muiderslot Martine Letterie, Het geheim van de roofridder (6+) Martine Letterie, Een valk voor Berend (6+)

Martine Letterie, Berend en het verdwenen stadszegel $(6+)$

Martine Letterie, Ridder in een slog, hoe Focke en Eilco worden opgeleid tot ridder (6+)

Brigitte Coppin, Arno in de ridderburcht (8+)

Deborah Murrell, Mijn eerste boek over ridders en kastelen ( $7+$ info)

Dugald Steer, Van schildknaap tot ridder (8+ info)

Philip Steele, Het beste boek over ridders en kastelen (10+ info)

Gerard Sonnemans, Ridders (series: Notendop junior) (10+ info)

\section{Background literature}

D.E.H. de Boer et al. ed., Wi Florens... De Hollandse graaf Floris $V$ in de samenleving van de dertiende eeuw, Utrecht 1996

\section{Websites}

www.literatuurgeschiedenis.n//teksten.asp? ID $=15$ (ballad about Count Floris and Gerard van Velsen) 


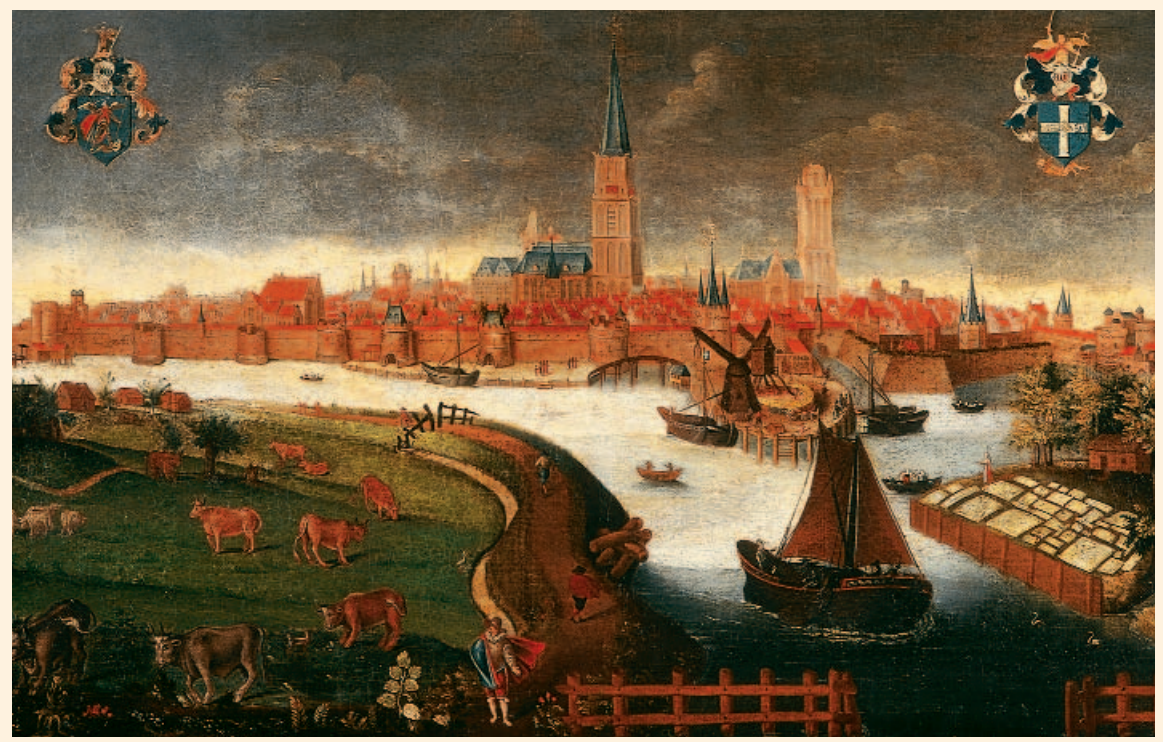

\section{6 - circa 1450 The Hanseatic League Trading towns in the Low Countries}

In the long period from the twelfth to the sixteenth century, the towns of Zutphen, Deventer, Tiel, Kampen, Zwolle and others (particularly in the east of the country) were important and prosperous trading centres. They were members of the Hanseatic League. A Hansa was originally a collaborative arrangement between merchants in various cities who traded in the same goods. By working together they could reduce their costs, travel more safely (together), make purchases or sell in bulk, and arm themselves against the capricious whims of liege lords. In 1356, the Hansa towns formed a league of not just merchants but whole towns. The decision to form the league was made in Lubeck, a town in what is modern-day Germany. The German Hanze, which is called the Hanseatic League in English, became a powerful collaborative network of towns that stretched across Germany, the Netherlands,
Belgium, the Baltic States, Norway and Poland. Within its network, the league attempted to alleviate restrictions on trade as far as possible. The Hansa network also traded with partners outside this area, with London, for example, and even with Spanish cities.

Trade was brisk in such goods as salt, grains, fish, wood, wine, beer, animal skins and cloth. The goods were mainly transported by sea and on rivers using so-called 'cogs' (ships) of between fifteen to thirty metres in length. The towns grew and prospered, built city walls and became dotted with merchant's homes, warehouses and many other types of buildings. The legacy of the Hanseatic League can still be seen in the towns mentioned above, as well as in smaller Hansa towns like Hasselt and Doesburg.

For non-Hansa towns like Amsterdam, trade across the Baltic Sea was the so-called 
"mother of all trade". This trade formed the basis for an economic boom. It also meant that this trade centre had to compete with the towns along the IJssel. When the Hanseatic League collapsed in the course of the sixteenth century, the Baltic Sea trade through towns outside the league continued to flourish. By 1585, Antwerp had become the true centre of trade and this position was later taken over by Amsterdam. Shortly afterwards, Dutch trade became increasingly focused on all the seven seas and became embedded in the conquest and exploitation of colonies. The shifting economic relationships in Europe resulted in the towns along the IJssel losing their prominent position.

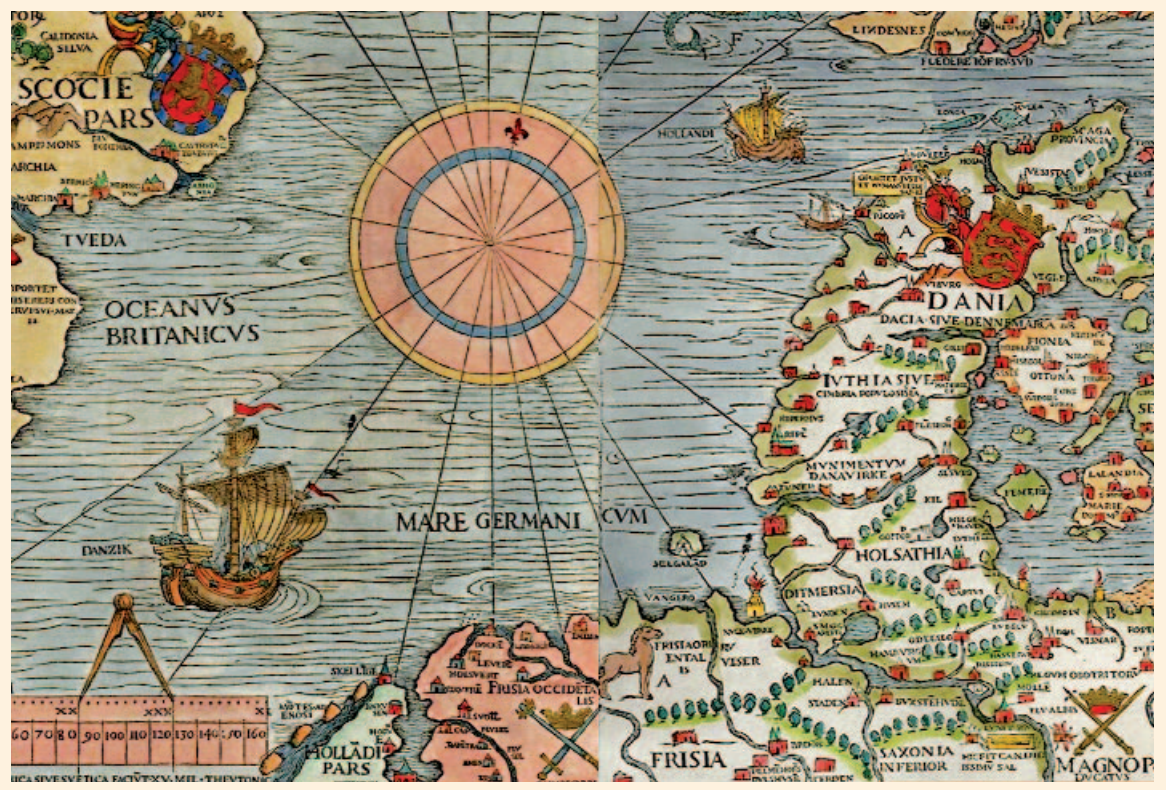

\section{Sub-topics}

\section{Primary education sector}

Life in a Dutch Hansa town in the late Middle Ages

(e.g. markets)

The transport of goods in the Hansa period: the cog (ship) Towns and villages along the IJssel

\section{Secondary education sector}

Amsterdam and the Hanseatic League

Economic history of the Hanseatic League

Urban heritage in Dutch (and German) Hansa towns

The role of merchants and traders in medieval towns

The collapse of the Hanseatic League

\section{Past and Present}

What are former Hansa towns doing with this tradition, e.g. for promoting their town and in tourism?

\section{In the Treasure chest}

Model of a $\operatorname{cog}$

\section{References}

Places to Go

Deventer: Historisch Museum

Kampen: a visit to the Kamper $\operatorname{Cog}$

Hansa town walk, available at the webshop of the Kampen Tourist Office (VVV)

Hansa detective, inside the town of Deventer

\section{Books for young people}

Thea Beckman, Gekoopt

\section{Background literature}

Frits David Zeiler and Ger Dekkers, Sporen van de Hanze: glorie van een gouden eeuw, Zwolle 1997.

De "Gouden Eeuw" van de IJsselstreek (1250-1550) en de betekenis van de Hanze, Zwolle.

\section{Websites}

www.deventergeschiedenis.nl/edu/index-edu.htm www.kamper-kogge.nl 


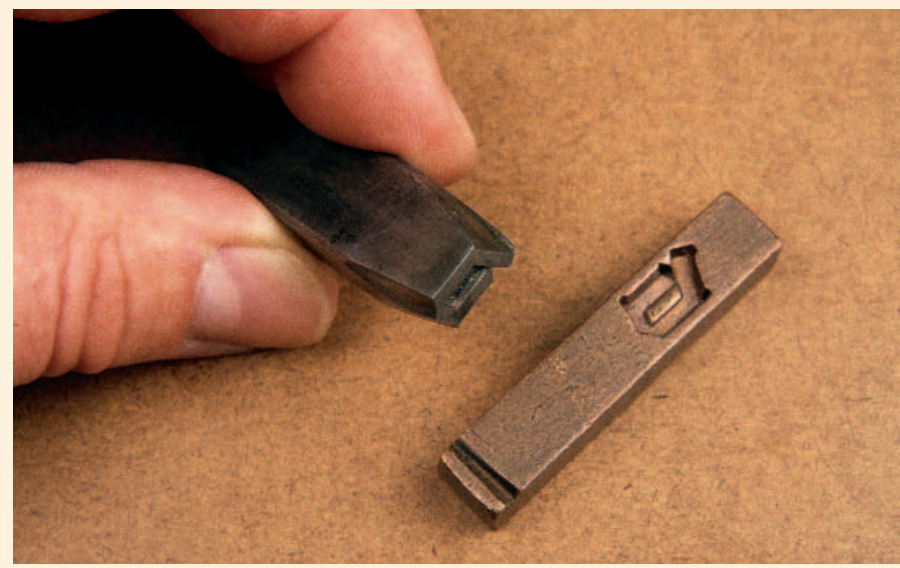

\section{circa 1450 \\ The printing press \\ A revolution in reproduction}

For centuries, the residents of Haarlem (and the Netherlands) believed their own Laurens Janszoon Coster was the inventor of printing. There is even a huge statue of him on the Grote Markt (town square) in Haarlem. However, the story of Coster appears to have been a romantic invention. In reality, it was Johannes Gutenberg in the German city of Mainz who invented the printing of books with moveable type in around 1455, when he printed the world-famous Gutenberg Bible. (Incidentally, a type of printing existed in distant China as early as the eighth century.)

The predecessors of Gutenberg used a printing method known as block printing, in which one complete page was carved into a block of wood and then printed. However, carving each block took a great deal of time and the blocks had to be discarded after the printing of only one book. Gutenberg discovered how to set a text using loose lead letters. Once the letters were made, you could set a new page quickly, and after printing the same letters could be reused.

Books could now be produced much more quickly than in the past. Whereas copyists needed months to copy a single book, now hundreds of copies could be printed in the same amount of time. Books were still expensive but were no longer only available to the elite few. The printing press also resulted in an explosion of printed material in all shapes and forms: a great many religious works were printed, but also simply-designed language and arithmetic books, travel journals and tales of knights in shining armour in prose form.

The first printers in the northern Netherlands were to be found in towns like Delft and Gouda. No printed material from the northern Low Countries has been found dating from earlier than 1473 , and the first book in the Dutch language only appeared in 1477 , the Delft Bible.

However, the cultural centre of gravity of the Low Countries had long been in 
the south. Antwerp developed into an international trade metropolis in the first half of the sixteenth century and boasted a varied cultural life. The town was teeming with printers who were prepared to print anything as long as it sold. One of these men was Christoffel Plantijn, the founder of the most famous printer's in the Low Countries. His "Polyglot Bible" of 1573 was a scientific edition of the Bible in three languages: Hebrew, Aramaic and Greek supplemented with Syrian and Latin translations and is regarded as one of the wonders of early printing.

After the fall of Antwerp (1585) many printers moved their workshops to the north. A century or so later, the Republic grew into a true printers' paradise where books could be printed that had been banned by governments or the church elsewhere. In the seventeenth century, more books were printed in the Republic than in the rest of Europe together. This phenomenon was referred to as the "Dutch Miracle".

\section{Sub-topics}

\section{Primary education sector}

From goose quill to the printing press and then the keyboard

The life and work of Christoffel Plantijn

Technological inventions of great significance

\section{Secondary education sector}

An early printing shop: Gerard Leeu

The Delft Bible of 1477

Type-setting and printing techniques (up to e-books)

Bibliophilist printed matter

Forbidden books

\section{Past and Present}

Is the development of the internet just as revolutionary as the transition from handwritten manuscripts to printed books was in its day?

What are the advantages and disadvantages of digital texts as opposed to printed material?

In the Treasure chest

Model of the Gutenberg printing press composing stick with loose lead letters

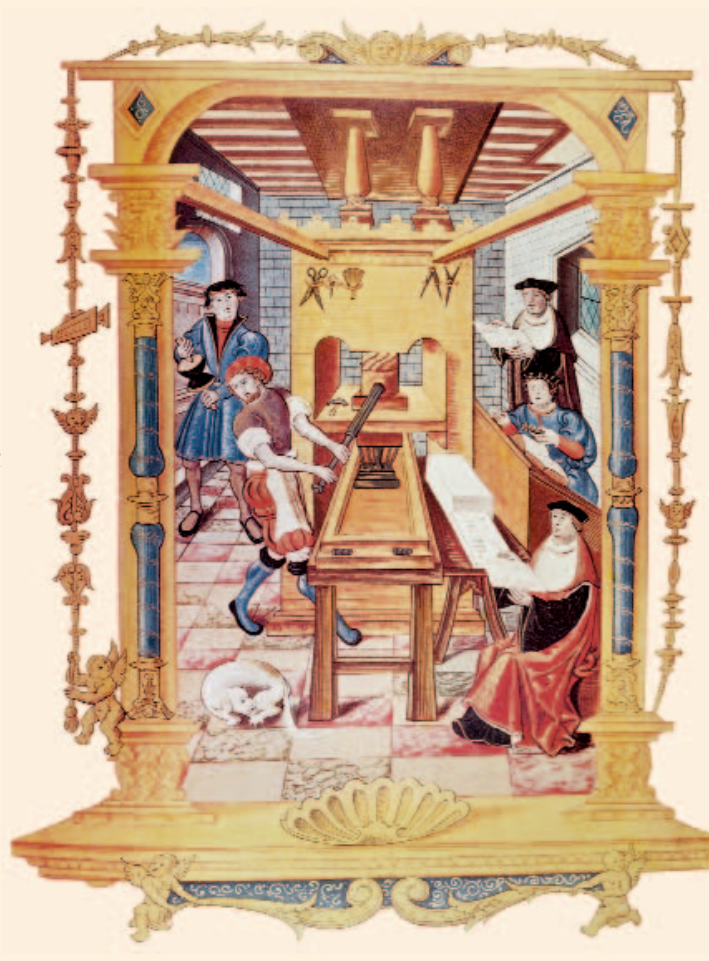

133

\section{References}

\section{Places to Go}

Antwerp: Plantijn Moretus (completely restored printer's workshop)

The Hague: Meermanno Museum

Mainz: Gutenberg Museum

Local traditional printers (www.drukwerkindemarge.nl)

Books for young people

Matthew Skelton, Endymion Spring (12+)

Renzo Rossi, Het tijdperk van het boek (12+ info)

\section{Background literature}

K.F. Treebus, Tekstwijzer: Een gids voor het grafisch verwerken van tekst, 's-Gravenhage 1990.

(By the same author: Vormwijzer, 1991)

Ed Schilders, In-druk: Von Wiegedruk tot Grafschrift, Tilburg 1995.

\section{Websites}

www.bibliopolis.nl

www.literatuurgeschiedenis.n//literatuurgeschiedenis.asp?ID=17 www.hrc.utexas.edu/exhibitions/permanent/gutenberg/ web/pgstns/01.html (Gutenberg Bible) 


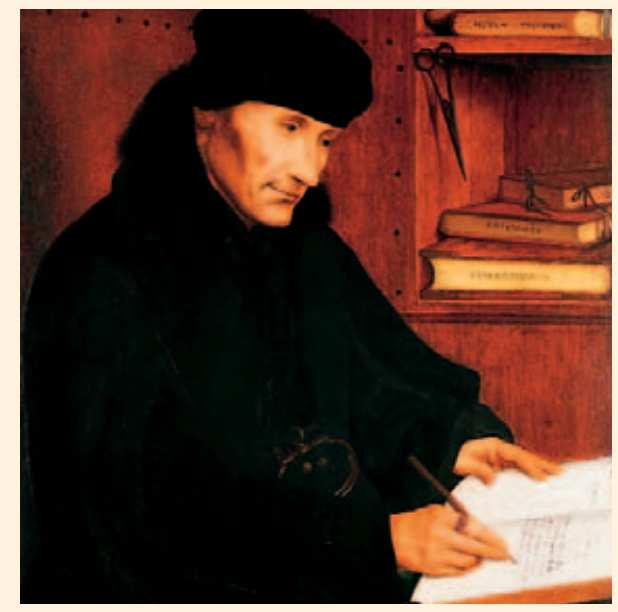

\section{$1469 ?-1536$ \\ Erasmus}

\section{An international humanist}

Erasmus had a complicated relationship with the land of his birth. He liked to call himself Desiderius Erasmus of Rotterdam, and yet repeatedly criticised the coarse manners and lack of taste of his fellow town-dwellers and country folk.

He was probably born in 1469 as the illegitimate son of a priest. This meant that a future as a monk was the obvious choice. After completing his training at a seminary of the Brethren of the Common Life, among other places, he joined the Augustinian monastery in Steyn near Gouda. Erasmus was taken with the monastery's library and immersed himself in the world of classical antiquity through the writings of classical authors and Italian humanists. The latter, with their enormous learning and critical approach, brought ancient times closer than ever before.

Monastic life with its strict regime and duties was suffocating. Erasmus's extraordinary knowledge of Latin gave him the opportunity to leave the monastery.
He travelled as an independent scholar across large areas of Europe, living from the income from his writing and gifts from a growing multitude of admirers. Erasmus stayed in contact with friends, like-minded scholars and informants through an extensive correspondence network. In 1500 he wrote Adagia, one of the world's first bestsellers, courtesy of the still new printing press. This collection of classical proverbs offered readers a speed course in the lifestyle and way of thinking of the humanists. In addition, Erasmus published books on etiquette, guides for heads of state, and dialogues and tracts that were aimed at educating lords and commoners to be good and responsible Christians.

Erasmus was the first to apply the humanist critical approach to Christian writings. He studied Greek specifically to read the writings of the early founders of the Church and the texts of the New Testament in the original language. This resulted in a series of new critical editions 
of early Christian writings, including a new edition of the New Testament in Greek with a new translation in Latin. With this Novum Instrumentum, Erasmus expressly distanced himself from the Vulgate (the official Church translation) and defended the right to adopt a critical approach to the Bible with the aim of strengthening the perception of faith. Erasmus hoped that one day everyone would be able to quote the Bible - the farmer behind his plough, the weaver at his loom and the traveller on his journey; he believed that even women should read

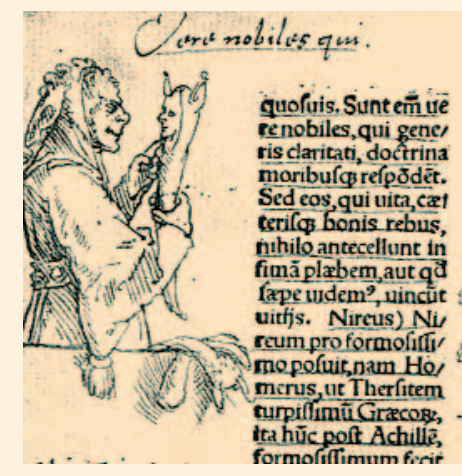

tino, at
ro non
ubicisn
Cühic
neNire
linease
fefeput
rius ner
marito,
fecredit
infania

\section{Sub-topics}

\section{Primary education sector}

The travels of Erasmus

Erasmus and young people

The ninety-five theses of Martin Luther

\section{Secondary education sector}

Humanism and the Renaissance

Modern devotion

The Reformation: Erasmus and Luther

Republic of the Letters; Latin as the language of scholars

(and English today?)

The Praise of Folly

\section{Past and Present}

Do the classics mean as much to us as they did to Erasmus? Erasmus as a man of our times

A comparison of the Erasmian rules of etiquette for young people (1530) and those of today

In the Treasure chest

Facsimile of the Praise of Folly by Hans Holbein the Younger the Bible. His ideal was the attainment of tranquil, austere devotion rooted in inner reflection.

In the polarisation that began in 1517 with the religious reforms of Martin Luther, Erasmus did not want to adopt a position - or did not dare to. He was not prepared to break away from the Catholic Church and hoped that the differences that had arisen could be resolved with sound reasoning. This caused him to be criticised by both sides. Erasmus died in the summer of 1536 at the home of the printer Froben, in Basel.

\section{References}

Places to Go

Brussels: Erasmus House

\section{Books for young people}

Maurits Tompot and Ines van Bokhoven, Het geheim van Erasmus (12+)

\section{Background literature}

H. Pleij, Erasmus en het poldermodel

\section{Websites}

www.erasmushouse.museum

www.wijsheden.net 


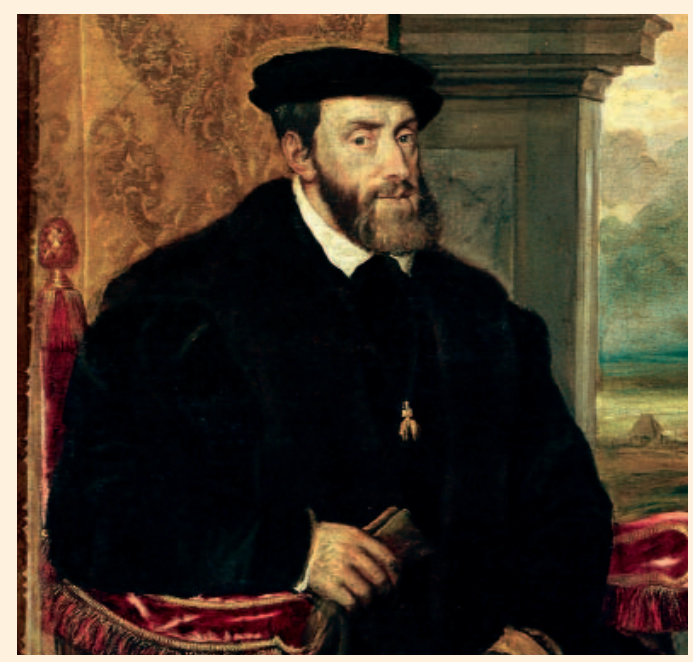

\section{$1500-1558$ \\ Charles V}

\section{The Low Countries as an administrative unity}

In the first half of the sixteenth century, the Low Countries consisted of different areas with their own laws and regulations. However, they had one thing in common: the Habsburg ruler Charles V. Charles's father, Duke Philip the Handsome, was a descendant of the Burgundians who had acquired a large number of dukedoms and counts' domains in the Low Countries in the late fourteenth century. His mother was heiress to the Spanish kingdoms of Aragon and Castile. Philip died when Charles was still young, so Charles had to ascend the throne early on in his life. In 1515 - at age fifteen - he became the ruler of the Low Countries; a year later he was also King of Spain and ruler of Spain's dominions in the New World; and in 1519 he was elected Emperor of the German empire.

This was the first time since Charlemagne that anyone had ruled over such a huge empire. Being emperor of an empire on which the sun never set created problems of its own. Confronted by hostile German princes, advancing Turks and a French king who mistrusted the expansion of the emperor's power, Charles moved from one war to the next. This cost a great deal of money that had to be supplied in part by the prosperous Low Countries. At the same time, Charles tried to make the Low Countries into an administrative unity and he conquered the last remaining independent provinces in the region: Frisland and Guelders.

This centralisation of politics was not welcomed by everyone. The towns resisted the high taxes and cherished their privileges, while the nobility defended their administrative functions against Charles's new civil servants. The presence of many supporters of the Reformation increased the tensions. Charles clung to the unity of the Church and took severe measures against dissidents: people who 
criticised the Roman Catholic Church created divisions. Charles had strict anti-heresy edicts proclaimed to the dismay of an ever-increasing group of town administrators and nobles who preached religious tolerance.

On 25 October 1555, in the golden hall of his Brussels palace, Charles abdicated his various positions. He was only fifty-five years old but he was burnt out from his administrative duties and gout.
Supported by the young prince William of Orange, he told those present of his love for the Low Countries, about the many efforts he had undertaken during his reign and of the mistakes he had made. He asked for forgiveness and begged those present to be as loyal to his successor, his son Philip II, as they had always been to him. Charles spent the last years of his life in a Spanish monastery where he died in 1558.

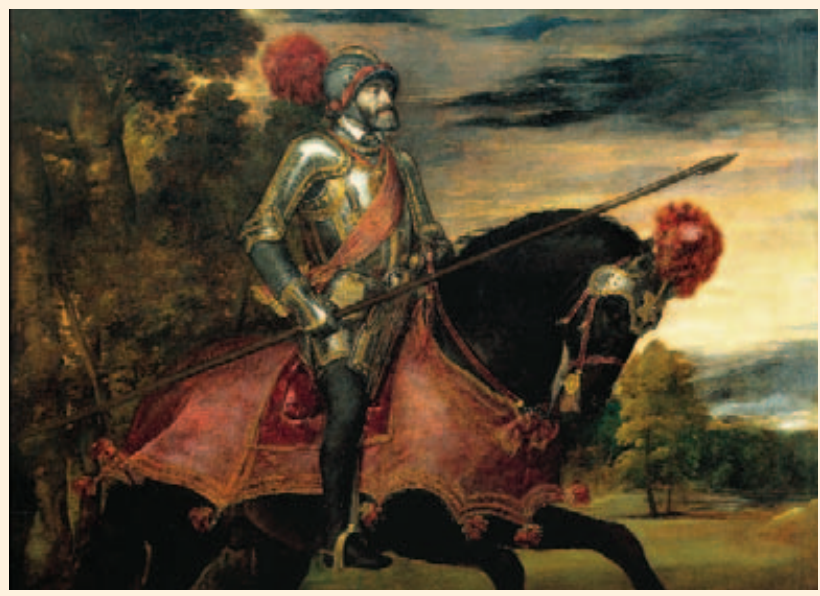

\section{Sub-topics}

\section{Primary education sector}

Charles's wars with the Frisians (Greate Pier) and the dukedom of Guelders (Maarten van Rossum)

Charles's connection to William of Orange

The conquest of Spanish America

\section{Secondary education sector}

Formation of the Burgundian state and rise of the house of Habsburg

Towns, nobility and privileges (class meetings)

Portraits of rulers

Europe in the time of Charles $\mathrm{V}$

The New World

\section{Past and Present}

The monarchy of Charles $V$ compared to that of Queen Beatrix

\section{In the Treasure chest}

Map of the Habsburg Empire

Medal of the Order of the Golden Fleece

\section{References}

Places to Go

Ghent: birthplace of Charles V

Brussels: BELvue Museum (finds from the excavations of the palace of Charles V)

Books for young people

Gerda van Cleemput, Katharina (12+)

\section{Background literature}

Hugo Soly and Johan van de Wiele (ed.), Carolus: Keizer Karel V 1500-1558, Gent 1999.

\section{Websites}

geschiedenis.vpro.nl/programmas/3299530/afleveringen/ 2142733/items/7535488

(audio from the Charles $\mathrm{V}$ memorial year)

socialact.be/gent/historis/keizerkarel/keizerkarel.htm (interesting section about Emperor Charles $\mathrm{V}$ and the Low Countries) 


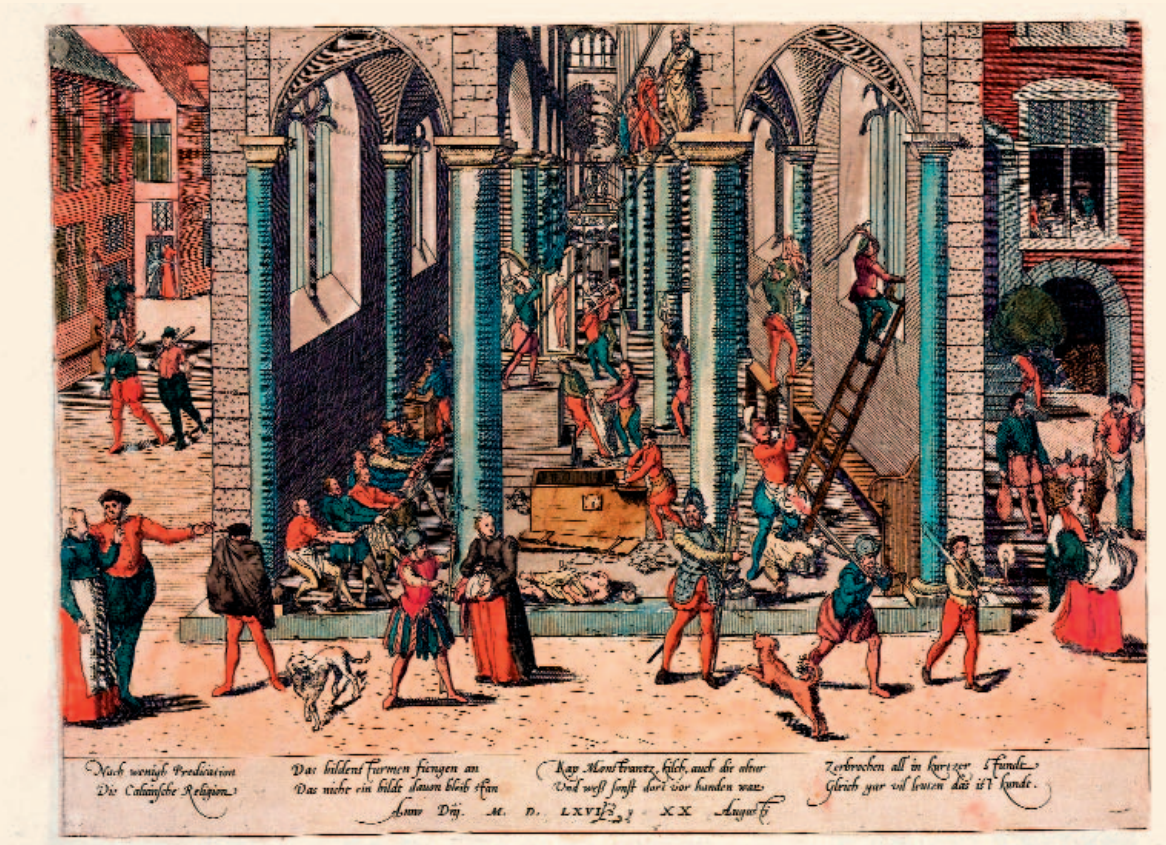

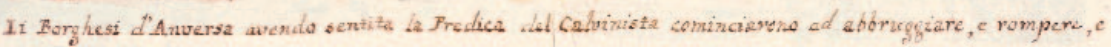
azcobeggiate le Chicos in Anveras.

1566

The Beeldenstorm (iconoclastic outbreak) Religious conflict

Contemporary accounts refer to 1566 as the year of wonders. And indeed, the dramatic events that took place in quick succession made it a "wonderful” year. On 5 April, two hundred noble landowners presented a petition to Margaret, Duchess of Parma. The nobles wanted religious persecution to cease and a meeting of the States General to be held to discuss the country's problems. The Duchess was shocked by the numbers of the nobles but a councillor whispered in her ear: 'They are just “gueux” (beggars)'. Several days later, when the same nobles entered into an alliance with one another, they decided to call themselves "Beggars". In recognition of this name, from that time on they carried begging bowls attached to their belts and wore a special medal around their neck. Profiting from the indecision that was rampant in the administration of the country after the submission of their petition, the dissatisfied nobles offered increasingly open resistance in subsequent months, while supporters of the "new faith" gathered in public to listen to the sermons of travelling Calvinist preachers. On 10 August, one of these open-air sermons resulted in the plundering of a nearby monastery. This happened near Steenvoorde, in the Flemish Westhoek, the highly industrialised textile centre of the Low Countries. In the weeks and months that followed, other churches and monas- 
teries were stormed and plundered, first in the rest of the Westhoek and then in other parts of Flanders and Brabant, and from the end of August, in the north of the Low Countries as well. With hindsight, there had been lots of omens. As a result of the severe persecution of heretics with the victims including ordinary, perfectly innocent men and women, unemployment and successive poor harvests, the situation had been inflammable for some time already. In the summer itself, the mood was predominantly one of surprise and astonishment and the wildest of rumours were rife.

The iconoclasts came from every layer of society. The high and low, rich and poor, male and female and young and old all stormed churches, destroyed images of saints and other works of art and plundered monasteries' stores. Their motives were as different as their backgrounds. Some hated the clergy with all their privileges, others were unhappy about

\section{Sub-topics}

\section{Primary education sector}

The Beggars (and the martyrs of Gorkum)

Catholic and protestant churches

Houses of prayer and worship in different religions

Secondary education sector

The Inquisition

Religion and rituals

Religious wars in France

Beggars' songs and church organs

Jan Pieterszoon Sweelinck (1562-1621)

Painted church interiors (Saenredam, Bosboom)

In the Treasure chest

Geuzenpenning (Medal of Honour)

Begging bowl

Images of saints their own meagre existence, while still others were simply curious, and the Calvinists believed the Church had to be purified of "papist superstitions". By drinking the communion wine, trampling consecrated wafers underfoot or feeding them to birds and smashing images of saints, they aimed to rid these Catholic symbols of their mystical value and make clear that Catholicism had been twisted into a sacrilegious puppet show of the true faith. By purifying the churches of their images of saints, altars, works of art and other unnecessary luxuries, the Calvinists believed they were restoring ties with the earlier, in their eyes more pure, Christians and washing away centuries of corruption and the worship of false saints. The purified churches would be suitable from now on for reformed services in which the Word of God was the focal point: Bible reading and explanations of the Bible by a preacher.

\section{References}

\section{Places to Go}

Amsterdam: Oude Kerk

Utrecht: the Catharijneconvent

Local: Catholic and Protestant churches

Books for young people

Bies van Ede, Oorlog op het ijs (12+)

Bies van Ede, De meester van het scherpe zwaard (Haarlem) (12+)

Rob Ruggenberg, Het verraad van Waterdunen (12+) Simone van der Vlugt, De bastaard van Brussel $\left(12^{+}\right)$ Thea Beckman, De val van de Vredeborch (12+)

Willy van der Steen, De geuzen (cartoon)

Fiona MacDonald, De Reformatie

(series: Oorzaak en gevolg) (14+ info)

\section{Background literature}

H. Kaptein, De Beeldenstorm. (Verloren verleden 18), Hilversum 2002.

\section{Websites}

www.schooltv.nl/vroegerenzo/ pagina.jsp?nr=vz_werkstuk\&wsnr $=443836 \#$ filmpje dutchrevolt.leidenuniv.nl www.dbnl.org (Beggars' songs) 


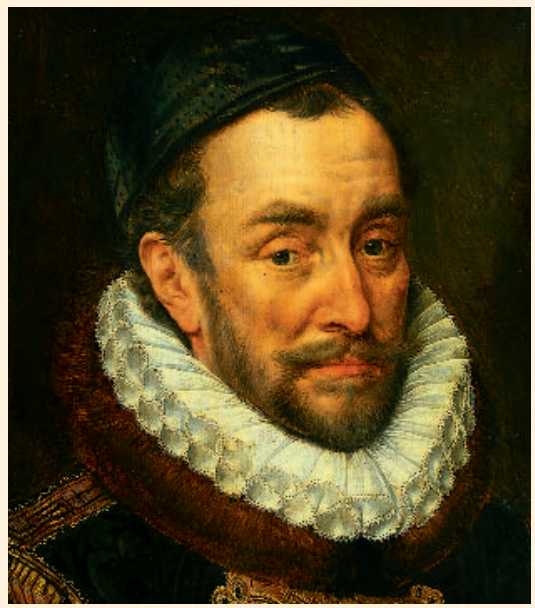

\section{$1533-1584$ \\ William of Orange}

\section{From rebel nobleman to "father of the country"}

William of Orange was an ambitious nobleman who grew into a rebel leader and was later honoured as the "father of the country", as the founder of a new Dutch state. He himself had never envisaged the emergence of an independent state.

William was born in 1533 at Dillenburg Castle (in Germany). His parents were Lutheran, but when he inherited the principality of Orange (in France) in 1544 and could call himself "Prince", emperor Charles V insisted that the young prince be raised a Catholic. For this reason, from age twelve, William grew up at the royal court in Brussels. He was raised in the French language in his new surroundings in a manner that befitted his new standing.

From 1555 onwards, William of Orange acquired high positions. As a military commander, member of the Council of State, Knight of the Order of the Golden Fleece and Stadholder (governor) of Holland, Zeeland and Utrecht he was one of the most powerful noblemen in the Low Countries. However, his relationship with Philip II, Charles V's successor, quickly deteriorated. William became the major spokesman of the noble opposition party. They were arguing for the persecution of heretics to be scaled down and they resisted the rise of professional civil servants in the administration of the country. The rise of the new civil servants meant that the nobility were losing their traditional positions.

After the debacle of the iconoclastic outbreak, William fled to Dillenburg. From here, from 1568 onwards, he undertook several military assaults on the Low Countries to bring to an end the rule of Duke of Alva. He also used propaganda (pamphlets, battle songs and cartoons) in this battle. One of the products of this period is the Dutch national anthem, the Wilhelmus. William had little initial success. Only when the Sea Beggars took Den Briel by accident on 1 April 1572 did 
the Rebellion begin to receive widespread support.

Against all expectations, the rebels in Holland and Zeeland continued to hold fast, due in part to the perseverance of William of Orange. With the Pacification of Ghent in 1576 the rebels even managed to make peace with the various provinces. The ideals of William of Orange seemed within reach: the restoration of the seventeen Burgundian Low Countries under the administration of the nobles, and the resolution of the prevailing religious differences, based on tolerance. However, the new unity did not last.

In 1580, Philip II placed a bounty on the head of William of Orange. William's

\section{Sub-topics}

\section{Primary education sector}

The assassination of William of Orange

William of Orange and the Beggars

The House of Orange and its symbols, including the Wilhelmus

\section{Secondary education sector}

The Dutch Rebellion

Beggars' songs: from flyers to Valerius

Religious wars

The rebellion from the Spanish perspective

The wives of William of Orange

\section{Past and Present}

The purpose of the Wilhelmus, then and now

The bond between the House of Orange and the people

In the Treasure chest

Beggars' Songbook response was to write an Apologie (defence) and the States General of the rebelling provinces responded with a Plakkaat van verlatinghe (Oath of Abjuration). Both these documents had the same message: resistance was justified because the king was acting like a tyrant. On 10 July 1584 a Catholic, Balthasar Gerards, shot William of Orange and brought an end to his life. William appeared to have achieved nothing, but less than twentyfive years later the rebellious provinces had developed into a self-confident Republic and William of Orange was regarded as the founding father of the

\section{References}

\section{Places to Go}

Delft: Museum Het Prinsenhof and the memorial monument at the tomb in the Nieuwe Kerk

Alkmaar: Stedelijk Museum (siege)

Leiden: Stedelijk Museum De Lakenhal (siege)

Breda: Royal Military Academy (court of the Nassau family in Breda)

Den Briel: city walk (1572)

\section{Books for young people}

Arend van Dam, Onder vuur

Joyce Pool, Vals beschuldigd (12+)

Willem Wilmink (ed.), Het Wilhelmus (10+)

\section{Background literature}

K.W. Swart, Willem van Oranje en de Nederlandse opstand 1572-1584, The Hague 1994.

\section{Websites}

dutchrevolt.leidenuniv.nl

www.inghist.nl/Onderzoek/Projecten/wvo

(letters of the House of Orange)

www.wilhelmus.nl/biografiewillem.html

www.gozcit.nl/epubgmd2/uploads///print/wvospeurtocht.PDF

(a hunt through Delft for children around the theme of William of Orange) 


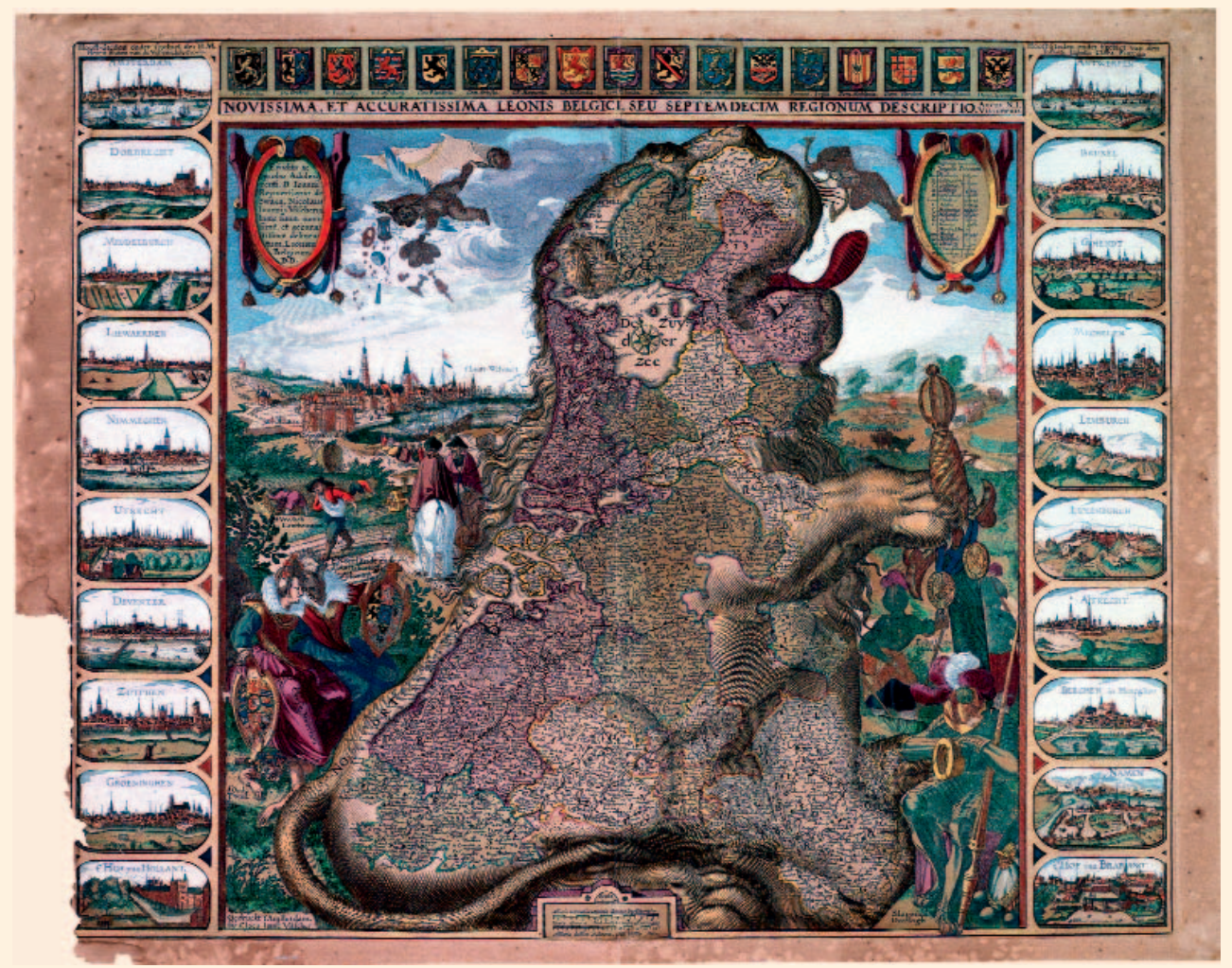

\section{$1588-1795$ \\ The Republic \\ A unique political phenomenon}

In 1609, the Twelve-Year Truce resulted in a temporary cessation of the war with Spain that had begun in 1568 with the military attacks of William of Orange. To commemorate the occasion, Claes Janszoon Visscher produced a map of the Low Countries in the shape of a lion, the Leo Belgicus. The map depicts the seventeen low countries as a unity, existing peacefully side by side thanks to the silencing of the guns, symbolised by the sleeping figure of Mars at the bottom right. In truth, however, the Low Countries had been split into two states by the Rebellion and the subsequent war: the southern, Spanish Low Countries and the northern Republic of the Seven United Low Countries. The latter had recorded a diplomatic success with the Truce even though international recognition as a sovereign state would only come in 1648 with the signing of the Treaty of Westphalia in Munster.

Republics were the exception to the rule in early-modern Europe where princes set the tone. Therefore, none of the rebels had actually been aiming to establish a republic: they had simply wanted to bring back "the good old days" when princes had 
guaranteed the freedoms and privileges of towns, provinces and subjects. Such a prince had been sought after the renunciation of Philip II, but had not been found. For this reason, in 1588 the seven remaining rebellious provinces took the form of a republic.

This resulted in a remarkable system of government in which, in theory, each province had an equal voice in the general meetings of the States General. Members had the right of consultation. This meant that delegates had to return to their provinces for consultation. Consequently, it could take a long time for decisions to be made. In practice the system was not too bad. Given that the wealthy province of Holland provided the most revenue, it also had the greatest say. The highest official of Holland, the Grand Pensionary, had duties similar to President of the Republic, Minister of Finance and Minister of Foreign Affairs all rolled into one. In addition, a member of the House of Orange usually held the office of Stadholder (governor). The Dutch term literally means “deputy" or "replacement”, but

\section{Sub-topics}

\section{Primary education sector}

The military successes of Maurice and Frederik Hendrik The death of Oldenbarneveldt

The States General

\section{Secondary education sector}

Republic and monarchy (forms of government)

Merchants and the ruling class as the most powerful group in the Republic

The court culture of the House of Orange

The conflict between Maurice and Van Oldenbarneveldt (church vs. state)

The murder of the De Witt brothers

Past and Present

States General, then and now

In the Treasure chest

Van Oldenbarneveldt's cane

Facsimile of the Treaty of Westphalia this was now simply a reference to early times: after all, there was now no liege lord who had to be replaced. As a high nobleman from the House of OranjeNassau (and therefore a descendant of William of Orange) and commander of the armed forces, the Stadholder was positioned well above all other administrators and officials. Whereas such civil servants spent their time largely in meetings, Stadholders like Maurice and Frederik Hendrik recorded military successes against the Spanish. They had something of the air of a prince about them, even though they were officially simply servants of the County Council.

The Stadholder and Grand Pensionary could easily come into conflict with one another. During the Twelve Year Truce, this happened for the first time, with a dramatic outcome. After a heated political and religious conflict, Stadholder Maurice had Johan van Oldenbarneveldt arrested on the charge of high treason. Oldenbarneveldt was sent to the block on 13 May 1619.

\section{References}

Places to Go

The Hague: the Binnenhof and surroundings

Amsterdam: Town Hall/Palace on Dam Square

Gouda: Sint Janskerk (St John's Church), stained glass windows

\section{Books for young people}

Arend van Dam, Onder vuur $\left(9^{+}\right)$

Lieneke Dijkzeul, Bevroren tijd (Nova-Zembla) (12+)

\section{Background literature}

A.Th. van Deursen, De last van veel geluk: de geschiedenis van Nederland, 1555-1702, Amsterdam 2004.

\section{Websites}

cf.uba.uva.nl/goudeneeuw www.koninklijkhuis.nl/content.jsp?objectid $=4551$ (Palace on Dam Square) 


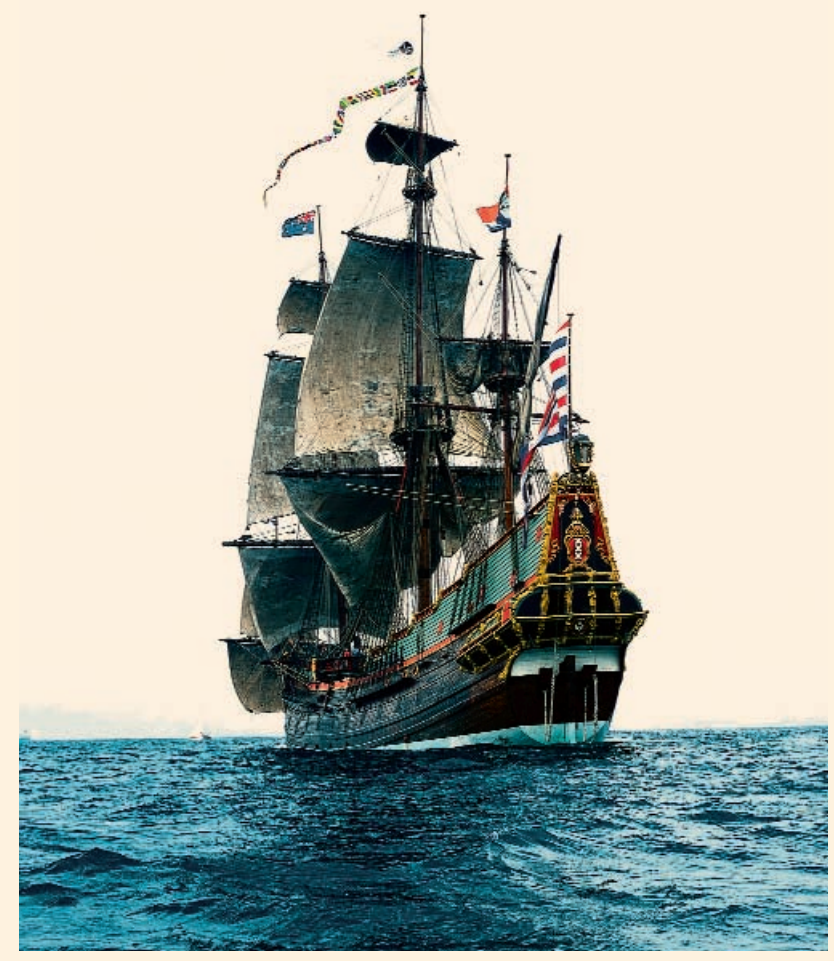

\section{$1602-1799$ \\ The Dutch East India Company (VOC)}

Overseas expansion

Mauritius, Hollandia and Amsterdam, these were the names of the three merchant ships that set sail from Texel for "the East", together with the small ship the Duyfken, on 2 April 1595. It proved to be an exciting adventure. Only three of the four vessels returned in August 1597 and only 87 of the 249 -man crew. The revenues were modest. But still, this first Dutch sailing expedition to Asia was a success because it opened a trade route to the East.

Other expeditions followed. With their strong and heavily armed trading vessels the merchant traders from Zeeland and Holland out-performed the Portuguese who had used the route for some time, and the
English became jealous. The ships returned heavily laden with colonial goods like pepper and nutmeg. To limit internal competition, Johan van Oldenbarneveldt took the initiative of setting up the Dutch East India Company (VOC). On 20 March 1602, the company acquired the Dutch monopoly on all trade in Asian waters from the Cape of Good Hope onwards. The company was empowered to sign treaties in the name of the Republic, to wage war and administer conquered territories.

The VOC developed into a power to be feared. 'This can lead to something big,' wrote Jan Pieterszoon Coen to the Heren XVII, the board of the VOC in the distant 
fatherland. In 1619, he conquered the town of Jayakarta and founded Batavia there. Coen wrote that 'Jacatra' would become 'the most important place in all the Indies' and that the reputation of the Dutch had increased through their conquests. 'Everyone will now seek to become our friend'. Parts of Java were occupied, Ambon and Ternate in the Mulluccas were subjugated and the population was forced to cultivate spices. Elsewhere in Asia too the VOC gained ground with either persuasion or violence. Forts were built in South Africa, India, Ceylon (Sri Lanka) and Makassar in Indonesia. China was visited and when in 1641 the Shogun of Japan closed his country's borders to foreigners, the VOC alone received his permission to continue to trade from the island of Decima near Nagasaki.

\section{Sub-topics}

\section{Primary education sector}

Sea travel (life aboard a ship), Captain Bontekoe

The surprises of exotic nature and culture: herbs, flora, fauna, people, goods and customs The Cape of Good Hope and Jan van Riebeeck (1652)

\section{Secondary education sector}

The beginnings of a world economy

The vOC and waging war

Indonesia before the arrival of the Dutch

Competition with the English and Portuguese

Exploring the world: exotic collections, botanic gardens (and the dodo)

Asian trade (India, China, Japan)

\section{Past and Present}

From a colonial economy to globalisation

Where can you still find the Dutch colonial legacy in the tropics? Should the Netherlands contribute towards preserving it?

Does the shock of the new still exist?

In the Treasure chest

Spices

Exotic shells

Ship's biscuits

Modern Delft blue
In this way, the VOC not only stocked Dutch warehouses with colonial goods and filled the houses of the bourgeois with curiosa from foreign lands, but they also played an important trading role within Asia. Textiles, spices, coffee, tea, tobacco, opium, tropical wood, iron, copper, silver, gold, porcelain, dyes, shells - an endless array of goods was transported by the Dutch East India fleet.

In 1799, in the time of the French, the VOC was dissolved. Today, the archives of the VOC are regarded as world heritage, a memory of the world. The daily reports of the merchants who organised trade from the forts, the reports of the travels of VOC officials to royal courts of rulers with whom they traded, ships' bills of lading... together the documents are an important source of information about two centuries of Asian-European history.

\section{References}

Places to Go

Lelystad: Batavia Shipyard

Amsterdam: Maritime Museum (replica of a voC ship)

Amsterdam: Royal Tropical Institute ("0ostwaarts"

exhibition and a relief of the first voyages)

voc walks in Amsterdam, Delft and Middelburg

Delft: Nusantara

Leiden: Museum of Ethnology

Utrecht: Moluks Historisch Museum

\section{Books for young people}

Johan Fabricius, De scheepsjongens van Bontekoe (12+) Rebecca Noldus, Zeekoorts $(12+)$

André Nuyens, De meikoningin (12+)

Vibeke Roeper, Land in zicht (10+ info)

Vibeke Roeper, Zwarte peper, scheurbuik (10+ info)

Annejoke Smids, Piratenbloed (12+)

Simone van der Vlugt, Bloedgeld (12+)

\section{Background literature}

Femme S. Gaastra, De geschiedenis van de VOC, Zutphen 2002.

\section{Websites}

www.voc-kenniscentrum.nl

voc.websilon.nl

www.vocsite.nl 


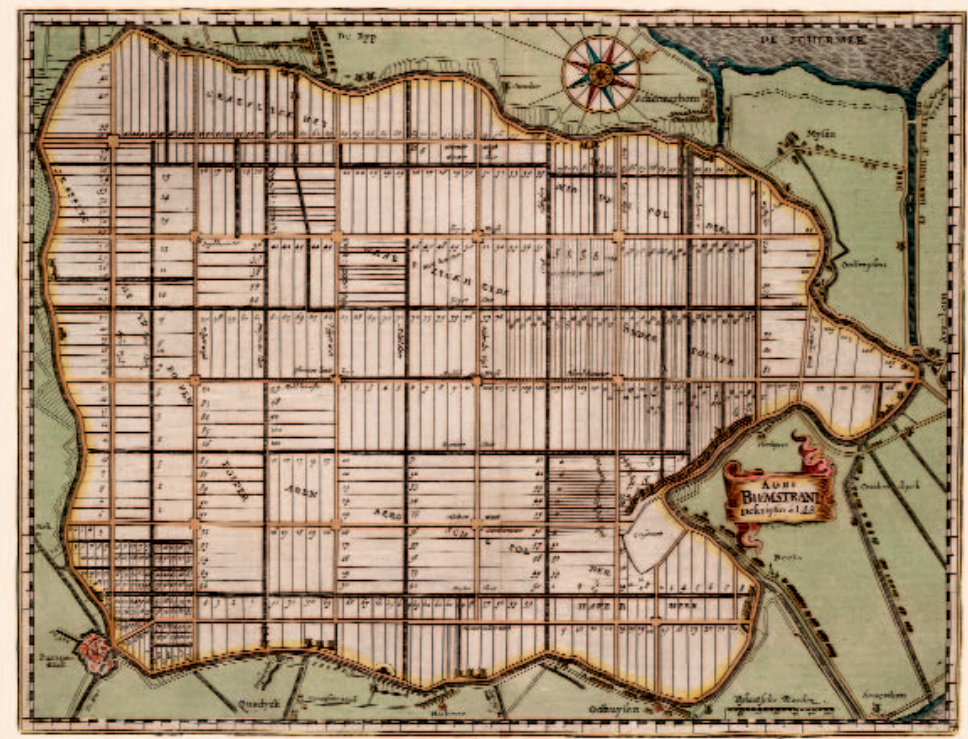

1612

\section{The Beemster Polder}

\section{The Netherlands and water}

There is a good reason for the fact that the Beemster Polder is listed on the Unesco World Heritage Register. The draining of this lake in 1612 is a shining example of how the Dutch "created" large areas of their country in the north, west and south-west of the Netherlands. The Netherlands took shape by man battling the elements. It started with small-scale land reclamation and the building of dykes in the Middle Ages. The scale became increasing larger from the sixteenth century onwards with the draining of lakes and peat bogs, and, for the time being, work was wound up in the twentieth century with the laying down of the Flevo polders and the Maasvlakte.

In 1607, a group of Amsterdam merchants and town administrators decided to drain the Beemster which at the time was a large lake. It promised to be a financially lucrative project that moreover would contribute to providing food for the fast-growing town of Amsterdam. A high, strong dyke with a length of 38 kilometres was built around the lake; around that dyke, the ring canal was dug. After this, work began on pumping the lake dry, using no fewer than 43 windmills. An engineer, Jan Adriaenszoon Leeghwater, was responsible for the building and placement of the windmills. A series of mills had to be built, each slightly higher than the last, so that the water was gradually pumped into the ring canal.

In 1612, the lake was dry and the polder could be laid out. Roads were laid, channels and ditches were dug and farms were built. The design was well-ordered in a tight geometric pattern. The Beemster Polder's fame is due to this parcellation and design. 
Over the centuries, a great deal of tinkering was done to the system of water management in the Beemster. For a long time it was the windmills that had to ensure that the residents kept their feet dry and that the water levels were suitable for land cultivation. In the late nineteenth century, the windmills were replaced by steam-driven pumping stations, and later still by diesel and electric-driven pumps. Today, the Beemster is divided into over fifty sections, each with its own water level. Farmers need a low water level under their land, while village residents want a high level to prevent the posts under their houses from rotting on

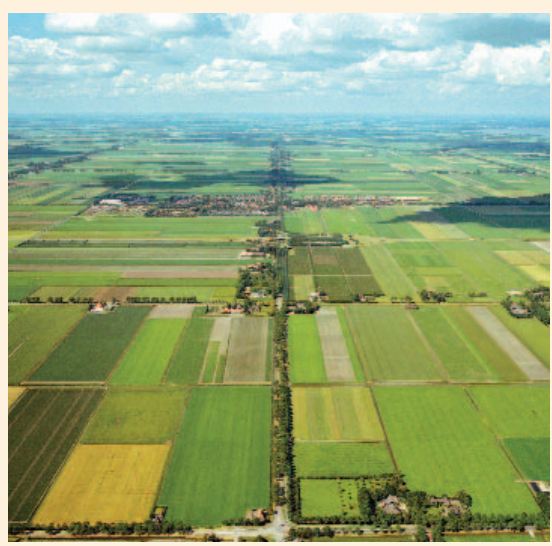

\section{Sub-topics}

Primary education sector

The life story of Leeghwater

Agriculture and cattle farming in the Golden Age

The Dutch landscape (polders, dykes and mills)

\section{Secondary education sector}

Water boards and water management

Technology (drainage and mills)

The background of land division

The landscapes of the Netherlands

Past and Present

Water management, then and now

Unesco World Heritage List

In the Treasure chest

Aerial photograph of the Beemster Polder contact with air. The ideal water level for cattle farmers is somewhere in between, while nature conservationists have their own requirements.

In the past, water was only pumped away to prevent flooding but today, in dry periods, water is also pumped into the Beemster. This is possible because the IJsselmeer, the former Zuiderzee, now contains fresh water of a quality suitable for agriculture.

The power of the wind and windmills once allowed the Beemster waters to be drained and land to be reclaimed. Today electricity and computers are used to manage the water levels.

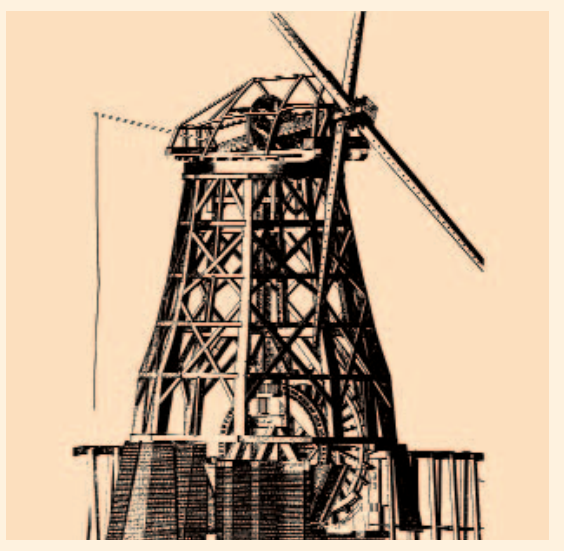

\section{References}

Places to Go Beemster

Cruquius: Cruquius pumping station

Books for young people

Peter Smit, Jan Jans Weltevree (10+)

\section{Background literature}

Herman Kaptein, "Jan Adriaensz. Leeghwater (1575-

ca. 1650)" in Els Kloek (ed.), Verzameld verleden: Veertig gedenkwoardige momenten en figuren uit de vaderlandse geschiedenis, Hilversum 2004.

Websites

www.beemsterinfo.nl www.beemster.net/erfgoed.htm whc.unesco.org/en/list (world heritage list) 


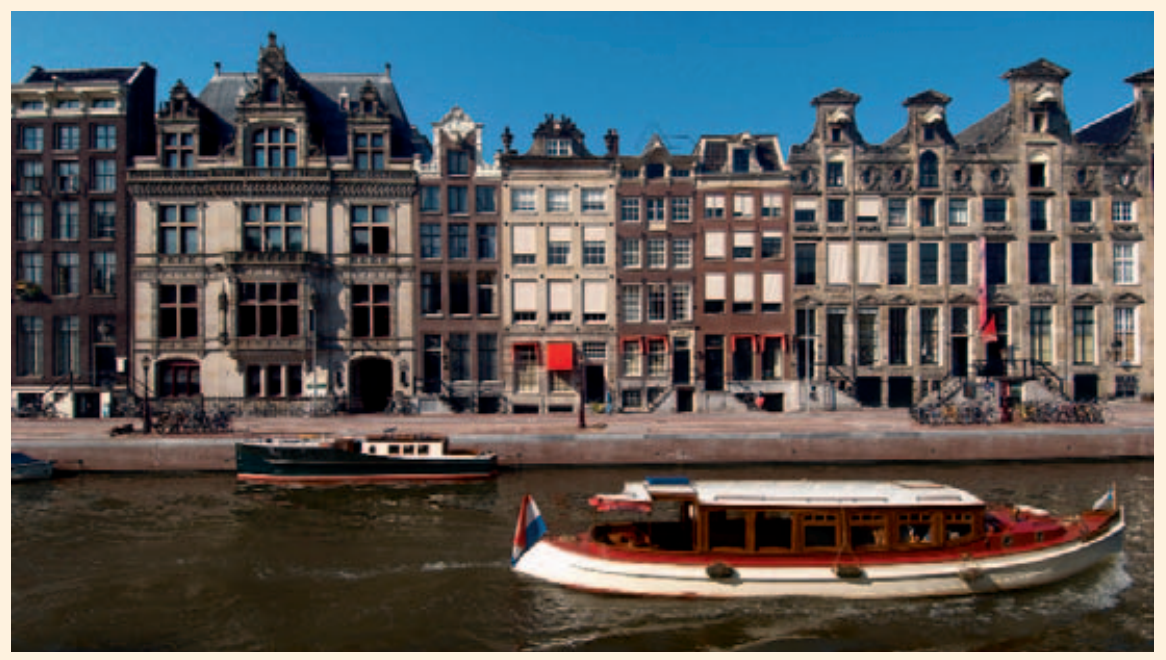

\section{$1613-1662$ \\ The canal ring}

Urban development in the seventeenth century

On aerial photographs and maps, the Amsterdam canal ring is immediately recognisable due to its characteristic semicircular form made up of the Herengracht, Keizersgracht and Prinsengracht canals in the centre of the city. The canal ring is a fine example of Dutch urban development in the seventeenth century. With the massive inflow of new arrivals in the prosperous western Republic from the end of the sixteenth century onwards, town administrators and town-dwellers were confronted with overcrowded towns, housing shortages and a lack of space. Urban development was unavoidable. But how could this be realised and what should the priorities be? Should the starting point be sensible considerations or aesthetic principles as set out in the popular tracts on the ideal city?

At the end of the sixteenth century, the city of Amsterdam made a cautious start at increasing urban space.
Large-scale development, however, only took place from 1613 onwards when the three canals mentioned above were dug up to the current Leidsegracht. A new western port area was realised by the creation of three rectangular islands and a new neighbourhood was developed to the west of the canals: the Jordaan. This was all done in accordance with a master plan involving various parties: the town administration, the Stadholder (governor), the Council of Holland and the town carpenter, Hendrick Jacobszoon Staets. It was a large project. Land had to be repossessed, new defences had to be built and funds had to be made available to finance the undertaking.

The elements of functionality and beauty were combined in the plan. Wherever possible, use was made of tight geometric shapes, which means the urban development features the consistent use of straight lines. In addition, the aim was 
to create a geographic division between the various urban functions. The new western islands mainly accommodated wharves and shipping companies, whereas the Jordaan district provided room for housing and small businesses. The canals had an exclusively residential function. Numerous “urban palaces” arose, built by wealthy merchants, bankers, town administrators and other men of means.

In the period from 1656 to 1662 , the canals were extended to across the river Amstel, which gave the centre of Amsterdam its current shape. The design continued along the lines of the first phase: new, even more lovely and bigger canal houses decorated this new section. Today, the Golden Bend of the Herengracht can still be regarded as a symbol of the wealth of the Golden Age.

At the time of this last development the Golden Age was drawing to a close. The development of 1662 had been too optimistic. The newly-won urban area to the east of the Amstel remained noticeably empty until far into the nineteenth century.

Today, the canal ring serves as a familiar example of typically Dutch urbanisation. The urban waterways, the small scale, the innumerable bicycles, the bustling city centre, these are the hallmarks of a true Dutch city.

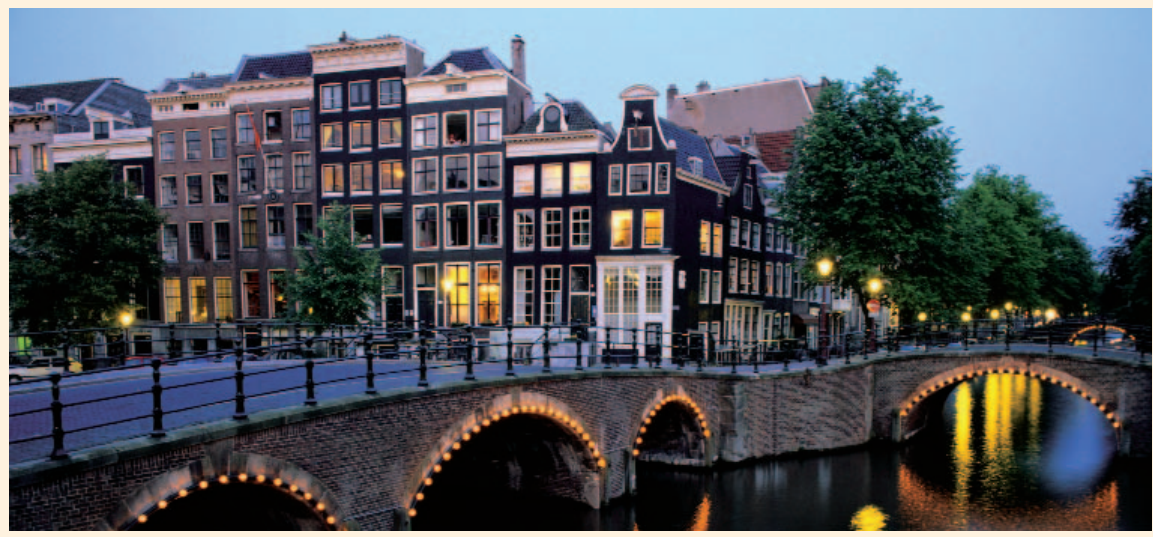

\section{Sub-topics}

Primary education sector

Dutch canal houses

Amsterdam in the Golden Age

A wealthy family on the canal: the Trippenhuis

\section{Secondary education sector}

The Republic as an urban society

Immigration

Paintings of cityscapes

Architecture

Modern urban development

Past and Present

The preservation of historic buildings in the Dutch cities

In the Treasure chest

Model of a canal house

\section{References}

Places to Go

Walks along the canals in Dutch cities and modern urban developments

Books for young people

Philip Steele, Zomaar een stad door de eeuwen heen ( $9+$ info)

\section{Background literature}

Boudewijn Bakker, "De zichtbare stad 1578-1813" in Willem Frijhoff and Maarten Prak, Geschiedenis van Amsterdam, centrum van de wereld, Amsterdam 2004.

\section{Websites}

www.amsterdam.nl/stad_in_beeld/geschiedenis/ de_geschiedenis_van 


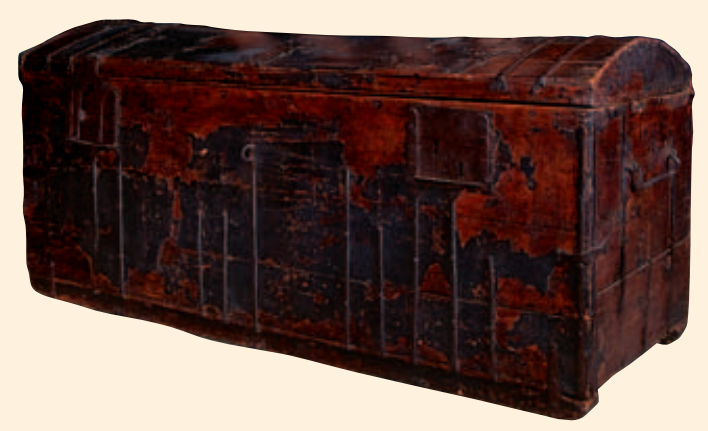

\section{$1583-1645$ \\ Hugo Grotius \\ Pioneer of modern international law}

Hugo Grotius was well known to the public at large mainly because of the book chest which he used to escape from Loevestein Castle on 22 March 1621. He had been imprisoned in the castle in 1619 for treason. As Pensionary of Rotterdam and political and legal advisor to government prosecutor Oldenbarneveldt, Grotius was one of the leading players in the Truce Negotiations. After the fall of Oldenbarneveldt, Grotius's days were numbered. Although (unlike his protector) he was not executed, he was sentenced to a life in prison. Thanks to the ruse with the book chest he did not serve his full term. He did, however, have to spend the rest of his life in exile abroad. Grotius died in 1645 in Rostock.

In 1621, Hugo Grotius's time in Holland came to an end but his intellectual activities and academic reputation continued to grow. He had earned his reputation early in life. A child prodigy, Grotius was born in 1583 in Delft and at age eleven he was admitted to the newly established University of Leiden. Here, he was hailed as the successor of Erasmus. The young Grotius had an unparalleled intellect. He could write Latin verses as easily as he could write annotations to ancient Greek and Roman texts. In 1598 the French king referred to him as "the Dutch miracle".

Hugo Grotius remained a man of many talents for the rest of his life. He wrote discourses on theological, historical, and, in particular, legal topics. Initially, his Dutch roots could be clearly seen in his writing. For example, using a flood of historical and legal examples he tried to prove that Holland had had the ideal form of government since the time of the Batavians, or that the Dutch were free to use the seas as these were international waters (Mare Liberum). The way in which 
he reached these conclusions was typical for humanist scholars like Grotius. Using his astonishing scholarship, his primary aim was to bring order and structure to existing knowledge as could be found in the works of classical writers. This approach delivered important new insights, particularly in his legal writings like De iure belli ac pacis ("On the law of war and peace”). Written in 1625, this work sets out the fundamental principles of international law.

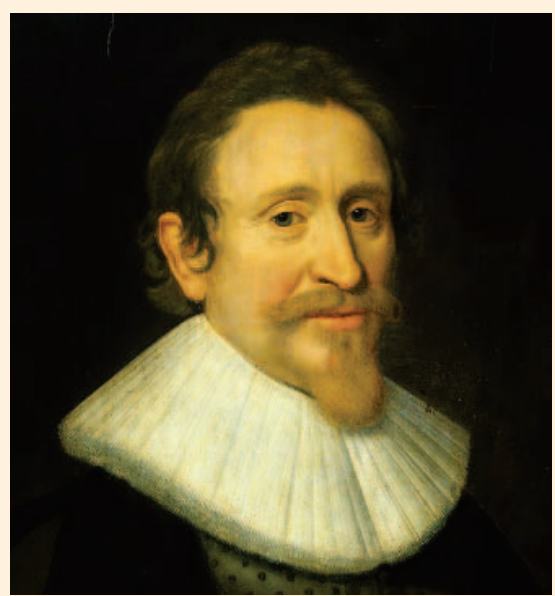

\section{Sub-topics}

\section{Primary education sector}

Hugo Grotius: from celebrated genius to banished exile Control of the seas ("mare liberum")

International legal systems: Peace Palace, United Nations, Red Cross

\section{Secondary education sector}

Truce Negotiations

The De Witt brothers

War and peace: international law

Humanism and science

Maria van Reigersberch

\section{Past and Present}

The Hague as a city of justice

Laws of war

Child prodigies

In the Treasure chest

Miniature book chest
In the Netherlands, Grotius is known as Hugo de Groot, and is still largely remembered for the tale of the book chest. Abroad, the name Grotius is associated with a man with a brilliant legal mind. Together with his fellow victims of the Stadholder (the De Witt brothers and Oldenbarneveldt), Hugo Grotius served as a symbol of resistance for the opponents of the Orangists. During the 178 os, the Patriot period, several relics of Grotius came to light, including two book chests.

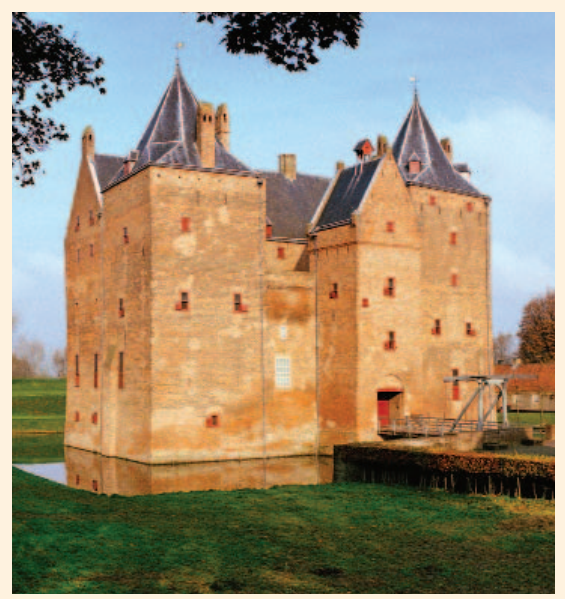

\section{References}

Places to Go

Loevestein castle

The Hague: Peace Palace

\section{Books for young people}

Marion Bloem, Zo groot als Hugo (8+)

\section{Background literature}

H.J.M. Nellen, J. Trapman (ed.), De Hollandse jaren van Hugo de Groot (1583-1621), Hilversum 1996.

Gijs van der Ham, "De Boekenkist van Hugo de Groot", in Els Kloek (ed.), Verzameld Verleden, Hilversum 2004.

\section{Websites}

www.hsmarnix.nl/studenten/hugo

www.un.org

www.nvvn.nl (Netherlands United Nations Association) www.rodekruis.nl 


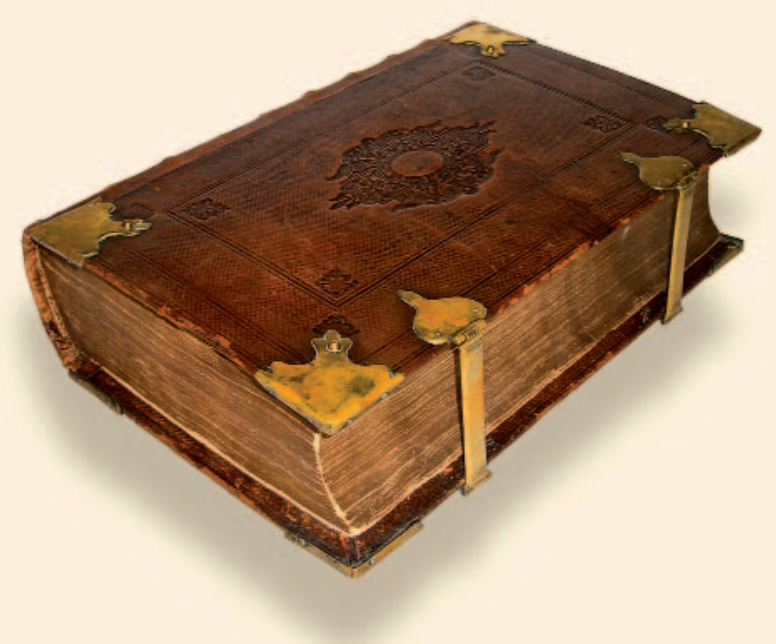

1637

\section{The Statenbijbel \\ (authorised version of the Bible) \\ The Book of Books}

For Christians, the Bible is the most important book in existence because it contains the truth revealed by God, "the word of God". One of the points of conflict during the Reformation had been the question of for whom the Bible was meant. The Catholic Church believed that the Bible should preferably not be read by ordinary people. Rather, they could listen to the explanations of the clergy in church, where the priests read from the Bible in Latin. The priests acted as intermediaries between God and the faithful.

The protestants, on the other hand, believed that the faithful themselves should be able to read the Bible and that the preacher in the first place was a servant of the word of God. It was the task of preachers to let God's word speak to the congregation, through Bible readings and exegis of the Scriptures. This meant, therefore, that the Bible should be available in the language of the faithful, preferably in as reliable a translation as possible. Consequently, the reformer Luther translated the Bible from the original texts into German in around 1535. In the sixteenth century, a number of Dutch translations were made of Luther's German work.

Over the course of time, the call from the Dutch Reformed Church became ever stronger for a new translation based on the original manuscripts of the Bible in Hebrew and Greek. In 1618, the synod of the Dutch Reformed Church, during its main assembly in the city of Dordrecht, commissioned such a translation based on the example of the English Authorised Version (the King James Bible of 1611). The States General was asked to finance the translation. 
The States General only agreed to this in 1626 and the translators were then able to start work. Nine years later the translation was completed, and in 1637 the Dutch authorised version, the Statenvertaling or Statenbijbel, was printed for the first time. Over 500,000 copies were printed between 1637 and 1657. The Statenbijbel remained the most important Bible in the Dutch Reformed Church for over three hundred years. Even today it is still used in some church communities. Currently,

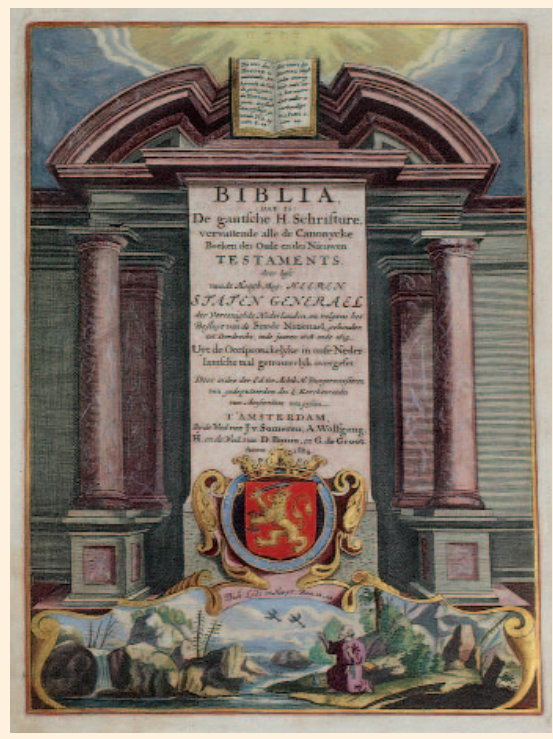

\section{Sub-topics}

\section{Primary education sector}

Holy books (the Bible, the Koran and the Torah) Stories from the Bible (the story behind Christian holidays)

Bible sayings and proverbs

\section{Secondary education sector}

The Synod of Dordrecht

The Bible and literature

World religions

\section{Past and Present}

The most recent Dutch translation of the Bible

In the Treasure chest

Facsimile of the Statenbijbel work is being done on a revised version of the Statenvertaling.

Over the course of time, through sermons and Bible readings, large groups of people became familiar with the language of the Statenbijbel, that also had an enormous impact on Dutch culture. The Statenvertaling was the source for expressions like "in the sweat of thy face" and "a feast for the eye", that have now become embedded in the Dutch language.

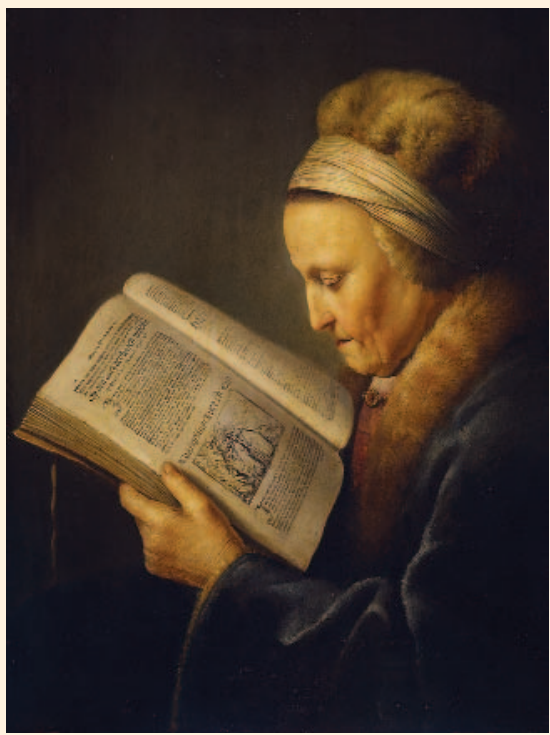

\section{References}

Places to Go

Amsterdam: Bible Museum

Amsterdam: Jewish Historical Museum

Utrecht: Catharijneconvent

Uden: Museum of Religious Art

Books for young people

Jan van Reenen, De komst van de Statenbijbel

Background literature

Els Kloek, "De Synode van Dordrecht (1618-1619)" in:

Els Kloek (ed.), Verzameld Verleden, Hilversum 2004.

\section{Websites}

www.statenvertaling.net www.bijbelencultuur.nl 


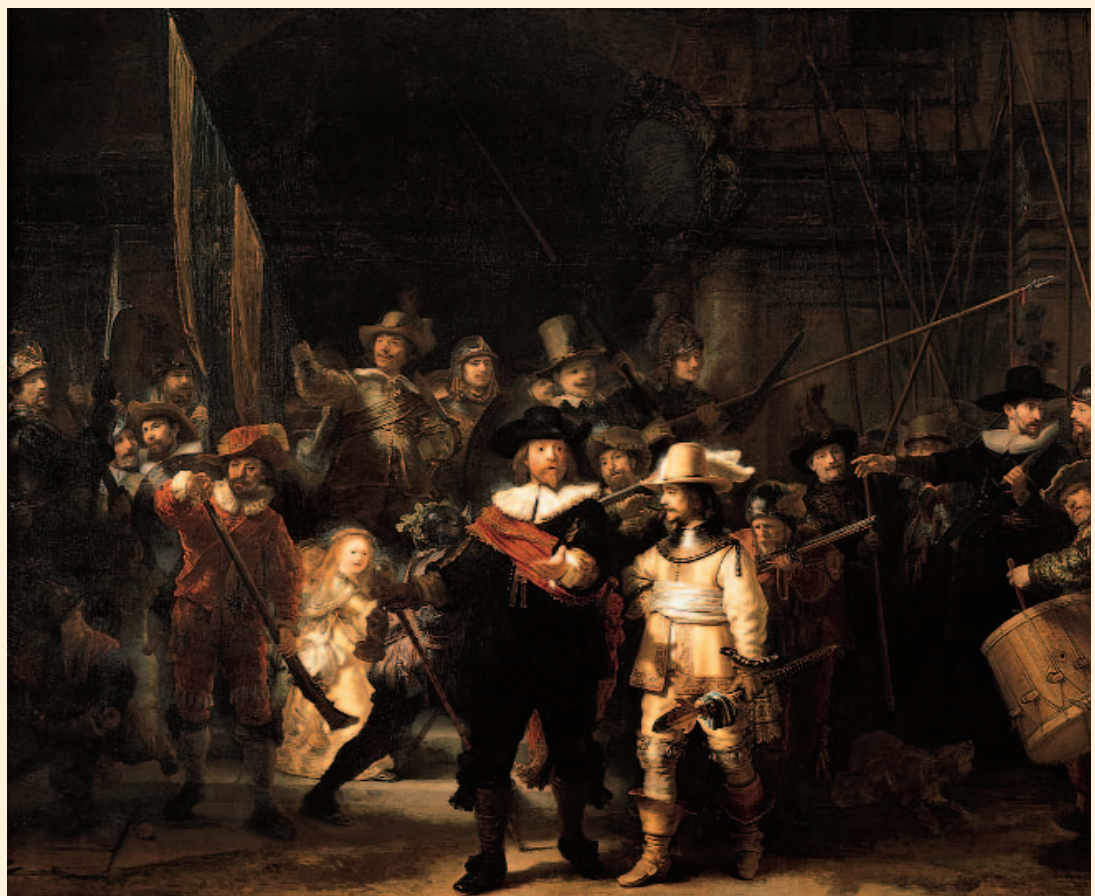

\section{$1606 ?-1669$ \\ Rembrandt \\ The great painters}

Rembrandt van Rijn's painting “The Night Watch" is world famous. The painting dates from 1642 and since that time it has been commented on, praised and discussed on innumerable occasions. It is indeed an intriguing painting: it depicts something - but what? On the other hand, it is an ordinary painting: a group of Amsterdam residents depicted as members of the civic guard around their Captain Frans Banning Cocq. The painting was intended to be hung in the new great hall of the renovated Kloveniersdoelen (the headquarters of the civic guardsmen). Such group portraits belonged to a tradition that dated back to the first half of the sixteenth century. Banning Cocq's colleagues did themselves equal justice: they too commissioned group portraits by well-known artists. Rembrandt's painting therefore originally hung in the company of a number of other recent group portraits in the new Doelenzaal of the Kloveniersdoelen where the guardsmen regularly met to eat, drink and smoke together.

At the time that Banning Cocq commissioned Rembrandt, the latter was already much in demand as a portrait painter. He was also ambitious and had left his birthplace (Leiden) at an early age in the hope of making a better career for himself in the richer, larger town of Amsterdam. He was successful. With his 
expensive portraits and paintings of biblical and mythological figures and stories, Rembrandt served the elite among the wealthy bourgeoisie and art lovers.

The Amsterdam art market was, however, much wider in scope. Around the year 1650, the city had some 175 artists. The majority of them produced cheap paintings for an anonymous market, mainly small landscapes and so-called genre pieces depicting everyday scenes. These painters did not achieve eternal fame, but their work is a mark of the wealth and scope of seventeenth-century Dutch painting. Spurred on by the great demand from ordinary citizens for paintings to decorate their homes, all over the

\section{Sub-topics}

\section{Primary education sector}

Famous paintings of Rembrandt and their stories The painter and his pupils (master - apprentices) Famous seventeenth-century painters:

Vermeer, Hals, Steen, Ruysdael

\section{Secondary education sector}

Commissioned art

Economics, society and cultural growth

The Muiden Circle

Art appreciation, "true" and false Rembrandts

Rembrandt as a global celebrity

\section{Past and Present}

What did the guardsmen in the painting like about Rembrandt's depiction, and what do we think about it?

In the Treasure chest

Palette, paints and brushes

Reproduction of a self-portrait of Rembrandt
Republic artists tried to create their own niche in the market. It has been calculated that in the seventeenth century over five million paintings must have been produced. This figure clearly illustrates that Dutch painting was not dominated by a few great masters working in important artistic centres such as Amsterdam, Haarlem and Utrecht. It is therefore not Rembrandt alone who symbolises the remarkable cultural boom of the seventeenth century, but also the hundreds of second and third-rate local painters who tried to make a living in the shadows of famous masters or working in smaller

\section{References}

\section{Places to Go}

Amsterdam: The Rijksmuseum and the Rembrandthuis Alkmaar: Stedelijk Museum Leiden: the Lakenhal

The Hague: Mauritshuis Haarlem: Frans Hals Museum

\section{Books for young people}

Thea Beckman, De stomme van Kampen (H. Avercamp) $(12+)$

Anne Marie van Cappelle, Het wonderlijke schilderij van Antonio (Brugge 1533) (10+)

Annejoke Smids, Meester van de schaduw (Caravaggio) $(12+)$

Dick Walda, Het mysterie van de Nachtwacht (12+) Jan Wolkers, De spiegel van Rembrandt (10+) Bert Natter, Rembrandt, mijn voder. Verteld door Titus van Rijn $(12+)$ Lyrisch van Rembrandt. Twintig nieuwe gedichten naar de oude meester $\left(14^{+}\right)$

\section{Background literature}

B. Haak, Hollandse schilders in de Gouden Eeuw, Amsterdam 1984. Gary Schwartz, De grote Rembrandt, Zwolle 2006.

\section{Websites}

www.rembrandthuis.nl www.holland.com/rembrandt400/consumer/nl geschiedenis.vpro.nl/dossiers/25903180 www.rijksmuseum.nl/onderwijs (with a Rembrandt game) 


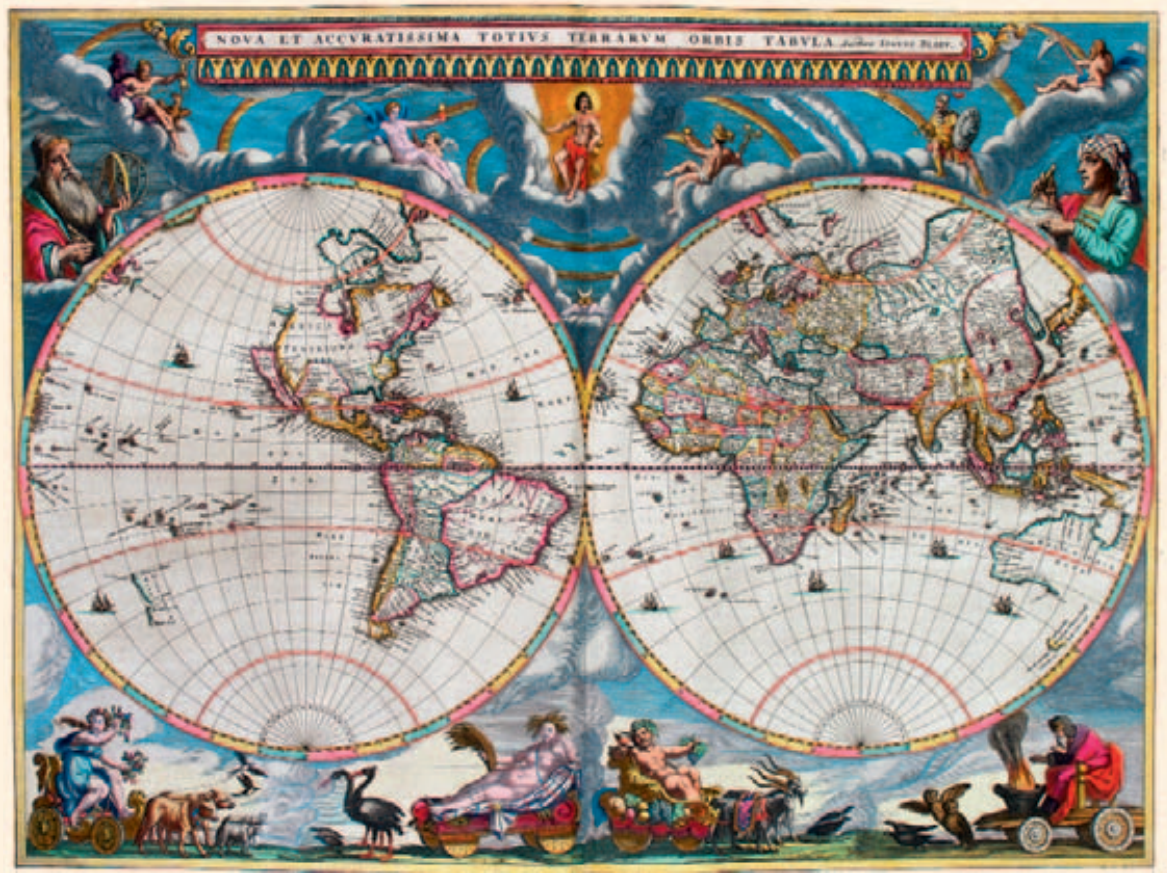

\section{2 \\ Blaeu's Atlas Major \\ Mapping the world}

In the seventeenth century, the Blaeu family was world famous for the atlases and maps printed by their family business in Amsterdam. The Republic was enjoying its Golden Age and Amsterdam was steadily growing as a centre of international trade, overseas expansion and wealth. Such a town provided the international contacts, the financial resources and the market for starting a thriving printing business in maps and atlases. Not only were there sufficient mariners and merchants who needed reliable navigation tools, also many wealthy members of the bourgeoisie appeared to be curious about the world beyond the horizon. They were prepared to pay for luxury editions of atlases or beautiful globes of the earth and the heavens.
This was not a completely new market. In the last decades of the sixteenth century, based on examples from abroad, cartographers in Enkhuizen and Edam had searched for suitable maps for mariners and other interested citizens. Willem Janszoon Blaeu responded to this demand, making good use of his knowledge of the subject and sound business instincts. After an apprenticeship with the famous Danish astronomer Tycho Brahe, Blaeu set up a printer's and publishing house in Amsterdam. His first printed maps date from 1605 and he distinguished himself from the outset by the quality and innovations in his work. Blaeu did not go out to take measurements himself. He designed his maps based on existing cartographic 
material, supplemented by the knowledge he drew from ships' logs, travel journals and talks with mariners. His maps and atlases gained Blaeu an international reputation.

After his death in 1638 , his son Joan took over the business. Joan expanded the family business still further and published numerous new maps and atlases, including the renowned Atlas Major, that was brought onto the market from 1662 onwards in various editions and languages. This multivolume atlas maps the known world of the time in six hundred maps and several thousand pages of descriptions. The atlas illustrated how knowledge of the world had been increased by voyages of discovery and trade contacts. At the same time, the atlas was a desirable status symbol, printed in folio format and bound in expensive leather if so desired. The maps themselves were beautifully printed but seldom original. Often, they had been published previously, sometimes they were outdated and they were largely inaccurate. However, all this had hardly any effect on the esteem in which the atlas was held. With his Atlas Major Blaeu had brought the known world within hands' reach in the loveliest way possible.
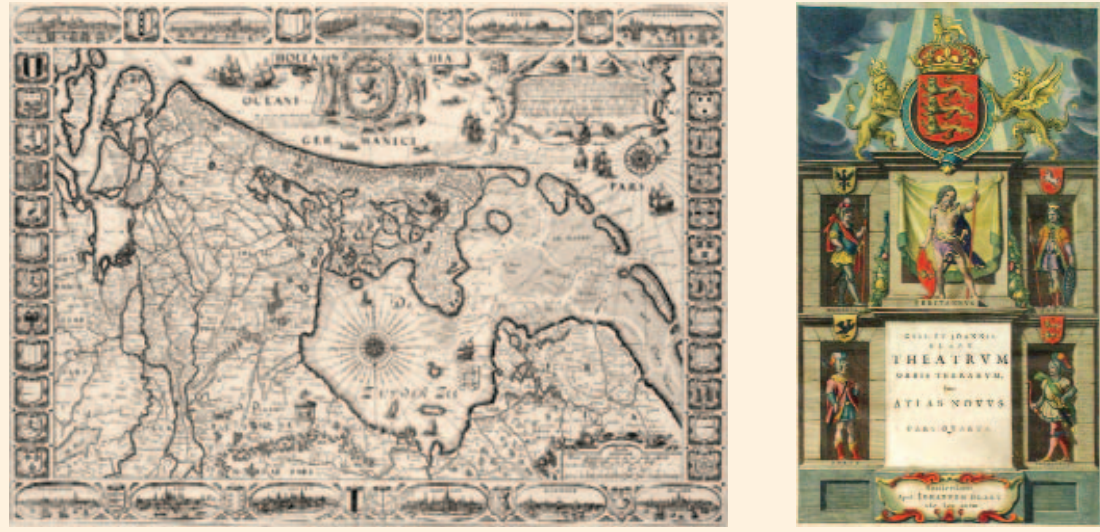

\section{Sub-topics}

Primary education sector

Shipping and navigation

The travel journal of Gerrit de Veer (Nova Zembla)

Learning to work with maps and atlases

Secondary education sector

Overseas expansion

Printing for the market

Famous cartographers abroad

Past and Present

Google earth

Satellite navigation

The marketprice of a Blaeu atlas

In the Treasure chest

Facsimile of the Atlas major

Navigation instruments

\section{References}

Places to Go

Amsterdam: Maritime Museum

Amsterdam: Amsterdam Historical Museum

Books for young people

P. Visser, Heemskerck op Nova Zembla

\section{Background literature}

Kees Zandvliet, Mapping for money: Maps, plans and topographic paintings and their role in Dutch overseas expansion during the 16th and 17th centuries, Amsterdam 2002.

\section{Websites}

www.scheepvaartmuseum.nl

www.uba.uva.nl (database of images of maps and atlases > Blaeu)

www.cultuurwijzer.nl (search for "cartography") 


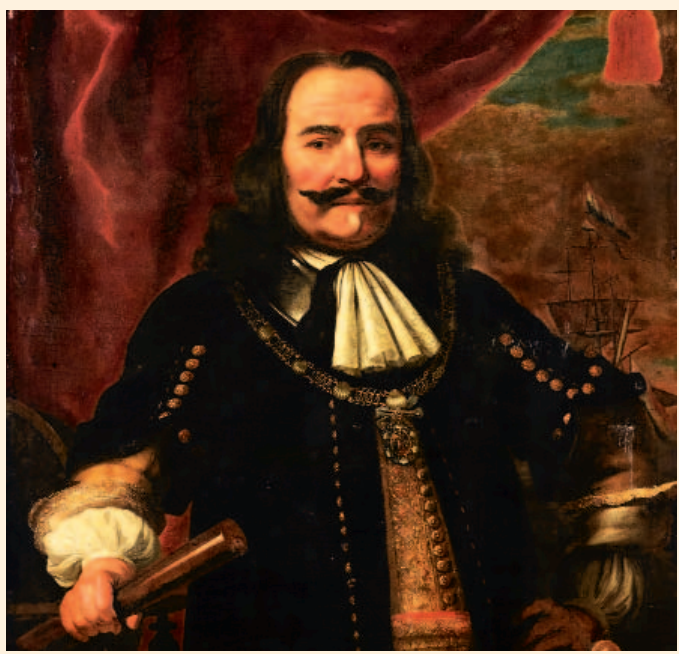

\section{$1607-1676$ \\ Michiel de Ruyter}

Heroes of the sea and the wide reach of the Republic

The Republic was at war for a large part of the seventeenth century. In 1648, the Eighty Years' War with the Spanish came to an end with the signing of the Treaty of Westphalia in Munster. However, the Republic did not enjoy peace for long. Conflicting trade interests quickly led to two sea wars with England (from 16521654 and from 1665-1667). In 1672, the English and the French launched a combined attack on the Republic that brought it to the brink of destruction. It managed to survive, however, and in the decades that followed the Republic played an important role in the international coalition that resisted the territorial ambitions of the French king Louis XIV.

In the meantime, the administrators of the coastal provinces presented the image of the Republic as a peace-loving maritime and trade nation that only waged war with the greatest reluctance to protect its economic interests. The great heroes in this self-made image were the admirals of the fleet and their sailors. Songs were written about them, their lives and deeds were set down in popular history booklets and major sea battles were depicted in paintings and prints. Fleet admirals who died in battle were assured of a magnificent mausoleum.

Michiel Adriaenszoon de Ruyter is without doubt the most famous of all seventeenth-century heroes of the sea. He was born in Vlissingen in 1607, the son of a humble beer porter. From early on it was clear that his future lay on the seas. After working for some time as a ropemaker for the Lampsins, the wealthiest family of ship owners in Vlissingen, in 1618 he signed on as an orderly for the Chief Petty Officer on his first ship. It was the beginning of an adventurous life on the seas. As a privateer captain, rear admiral and merchantman he sailed the world's oceans and tried his luck. 
In 1652, he believed he had acquired sufficient wealth to lead a tranquil life on shore. However, De Ruyter did not enjoy his rest for long. After the outbreak of the First Anglo-Dutch War, the Admiralty of Zeeland offered him a position. De Ruyter accepted, for one voyage. However, this soon appeared to be the start of a new career culminating in his appointment to the highest position in the navy, that of Lieutenant-Admiral.

De Ruyter's greatest moment came in 1667, at the height of the Second Anglo-Dutch War. On the urging of Grand
Pensionary Johan de Witt, De Ruyter sailed his fleet up the Thames and into the Medway, inflicting an embarrassing defeat on the English on their own soil. A large part of the English fleet was destroyed on the Medway near Chatham. De Ruyter was hailed as the new Hannibal.

In 1676, De Ruyter died in a battle against the French near Syracuse. It was to have been his last expedition. He was buried in a marble mausoleum on the spot where the high altar had formerly stood in the Nieuwe Kerk in Amsterdam.

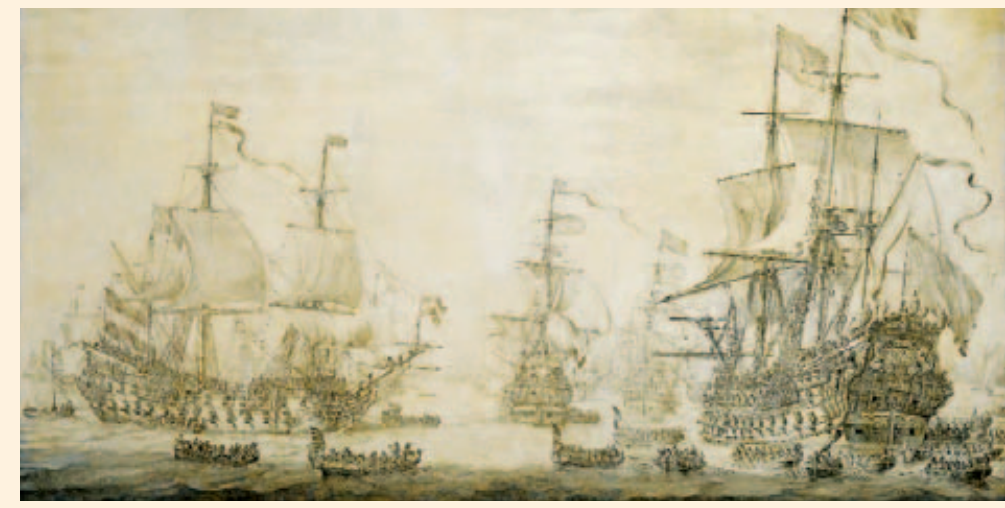

\section{Sub-topics}

Primary education sector

The expedition to Chatham

The funeral of De Ruyter

Other heroes of the sea

\section{Secondary education sector}

Trade wars

Europe after the Treaty of Westphalia

Sculpture in the Republic

odes

Heroes of the sea as national symbols

\section{Past and Present}

Upcoming commemoration of De Ruyter

In the Treasure chest

Model of the Seven Provinces

\section{References}

Places to Go

Vlissingen: De Ruyter walk

Amsterdam: Nieuwe Kerk (mausoleum)

Amsterdam: Maritime Museum

Amsterdam: Rijksmuseum

Rotterdam: Maritime Museum

Books for young people

Joh. H. Been, Paddeltje, scheepsjongen van Michiel de Ruyter

\section{Background literature}

R. Prud'homme van Reine, Rechterhand van Nederland. Biografie van Michiel Adriaenszoon de Ruyter, Amsterdam 1996.

\section{Websites}

www.deruyter.org

www.admiraelderuyter.nl

geschiedenis.vpro.nl/dossiers/27189490 


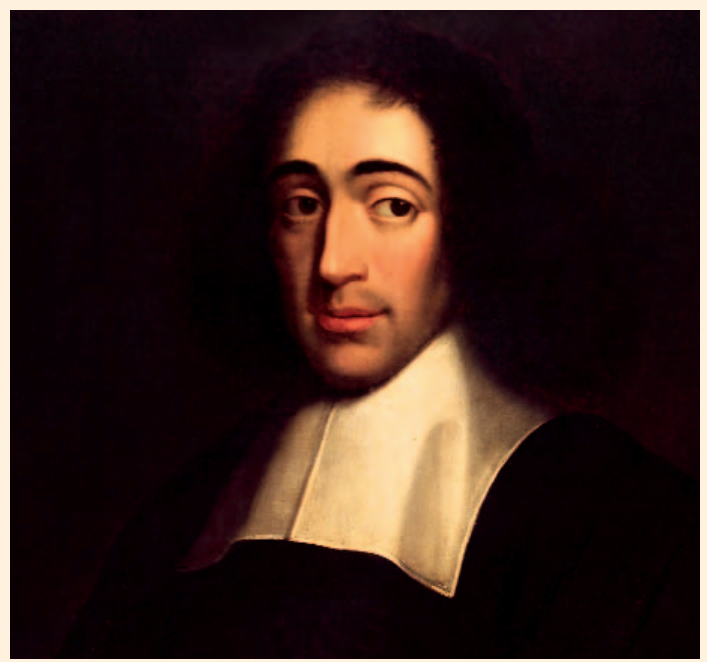

$1632-1677$

\section{Spinoza}

\section{In search of truth}

Spinoza is the most famous philosopher of the Netherlands: he belongs to a small group of philosophers who changed the course of western thinking.

Benedictus de Spinoza was born in Amsterdam in 1632 as Baruch d'Espinoza, the son of Jewish parents who had fled from Portugal. He died in The Hague in 1677 of a lung disease. Spinoza lived a quite frugal life and to earn his keep he ground lenses for glasses and microscopes. His illness was probably aggravated by the dust he inhaled in this work.

Spinoza's nickname was "Bento", which means the same in Portuguese as Baruch in Hebrew and Benedictus in Latin: "the blessed". Spinoza learned Dutch, Portuguese, Spanish and Hebrew and later wrote in Latin. After his religious training, in 1656 he came into conflict with the Amsterdam Jewish community. Probably not because he was critical of orthodox beliefs, but rather because he did not want to conform outwardly to the strict orthodox rules and requirements.

Although in comparison with surrounding countries the Republic was tolerant and dealt patiently with criticism, Spinoza still had to be careful. He published a lot of his works under a pseudonym - or not at all. His major work, the Ethica, was only published after his death.

In the "disaster year" of 1672 , the atmosphere became increasingly turbulent and the De Witt brothers were lynched by an Orangist mob without any interference from the authorities. This shocked Spinoza so deeply that he wanted to take a placard to the spot bearing the text ultimi barbarorum ('you are the greatest of all barbarians'). His landlord and friend stopped him and in so doing probably saved his life.

In his book Tractatus theologico-politicus Spinoza gave the initial impetus to a free-thinking interpretation of the Bible. 
In the Tractatus politicus he spoke up for democracy and pointed out the enormous importance of freedom of expression.

The Ethica (in full the Ethica Ordine Geometrico Demonstrata), Spinoza's masterwork, was meant to teach people how they could lessen their suffering. This was not philosophy for its own sake, because the book had a practical objective: to teach people to see that God is part of Creation, that everything that exists is a manifestation of God - including human beings. In order to come to this clear realisation it was of the utmost importance to be independent and free of intense passions. Spinoza lived his beliefs: his arguments were always presented calmly, were well-considered and reasonable. He did not ever allow himself to be provoked.

The Ethica appears to be structured like a geometric system. Spinoza uses definitions, axioms and propositions: in this way he tries to approach matters objectively despite the turbulence of the times. Throughout history many readers have complained that this makes the book very difficult to read. But then Spinoza has the last word, because the final sentence of the Ethica says: "All noble things are as difficult as they are rare."

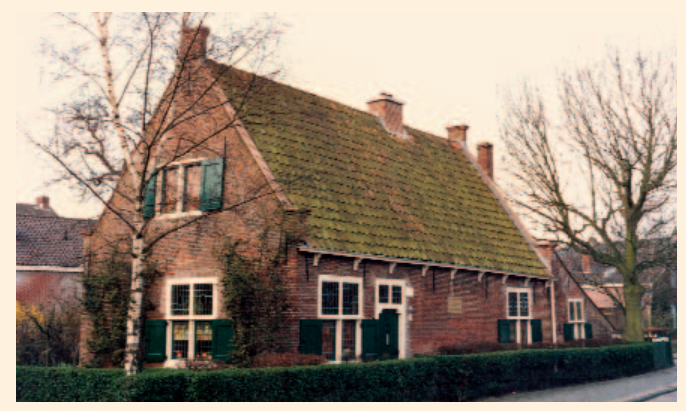

\section{Sub-topics}

\section{Primary education sector}

The Disaster Year of 1672: desperate (the leaders), lost to reason (the people), unredeemable (the country) Jewish culture (in Amsterdam and elsewhere) Freedom of worship and speech Immigration and assimilation

\section{Secondary education sector Western philosophy Religion and morals \\ Different seventeenth-century theories on democracy: Hobbes and Spinoza}

\section{Past and Present}

Einstein: "I believe in Spinoza's God"

Tolerance, now and then

Flowers, teddy bears and letters at the scenes of disasters examined as contemporary ultimi barbarorum placards

In the Treasure chest

Model of old microscope/telescope/glasses

\section{References}

Places to Go

Rijnsburg: Spinozahuis The Hague: Spinozahuis A synagogue (in Amsterdam or elsewhere)

\section{Books for young people} Henk van Kerkwijk, Het rampjaar (10+) Jostein Gaardner, De wereld van Sofie $\left(14^{+}\right)$

\section{Background literature}

Jonathan Israel, Radicale Verlichting: Hoe radicale Nederlandse denkers het gezicht van onze cultuur voorgoed veranderden, Franeker 2005

\section{Websites}

www.despinoza.nl 


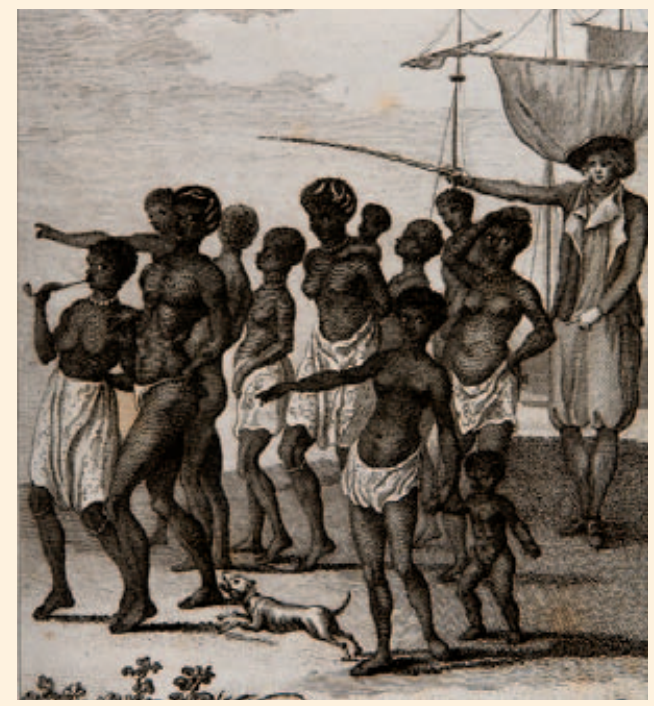

\section{ca. 1637 - 1863 \\ Slavery}

\section{Human trafficking and forced labour in the New World}

Since the great ocean crossing of Columbus in 1492, Europeans had been settling in what they called the New World, at the expense of the indigenous populations. The Portuguese began this by setting up sugar plantations in Brazil and having these worked by slaves brought across from Africa. This policy was adopted by all the European colonial powers. Together, in some two hundred years they transported over twelve million Africans in the transatlantic slave trade. The Dutch themselves transported more than 550,000 of these slaves. Some artists recorded their miserable lot in a drawing.

The Dutch slave trade started in 1621 with the establishment of the Dutch West India Company (WIC). WIC ships were originally sent out as privateers and to wage war on the Spanish-Portuguese fleet. In 1628, admiral Piet Hein captured the Spanish silver fleet, and in 1638 the
Portuguese lost Saint George del Mina in modern-day Ghana to the WIC. In addition, parts of Brazil were occupied (1624-1654) and in 1665 the Republic's claim to colonial rights over the so-called Wild Coast (Surinam, Berbice, Essequibo-Demarary), and the Antillean islands of Aruba, Bonaire, Curaçao, Saint Martin, Saint Eustatius and Saba was recognised.

The Dutch became important players in the Atlantic area as a colonial power and slave traders. Up until 1730, the WIC held a monopoly on the slave trade. Subsequently, the Middelburg Commercial Company (established in 1720) grew into the biggest Dutch slave trader, with various auction houses in Rotterdam and Amsterdam to compete with the WIC. In around 1770, the Dutch slave trade reached its zenith, transporting some six thousand slaves each year. In following years these numbers quickly decreased. 
Being a slave meant being forced to work and having no say in where, with whom and how you would live. The African slaves, and their descendants who were born into slavery, worked on plantations growing sugar, coffee, cocoa, cotton and tobacco. They worked in the salt ponds of Curaçao or waited on their masters. Not all slaves accepted their lot. Particularly in Surinam, people escaped from slavery by running away. They settled in the jungle and established their own communities alongside those of the Indians. These fugitive slaves were referred to as Maroons or Bush Negroes. In addition, there were constant small and large slave uprisings on plantations and in the towns. The largest slave

\section{Sub-topics}

\section{Primary education sector \\ Life on plantations \\ Slave uprisings and escapes \\ Slave songs (such as Faya siton); Afro-Surinam culture; Antillean music}

\section{Secondary education sector}

Plantation economy and farming

An international comparison of the abolition of slavery and emancipation

Afro-Surinam culture

African history

Contract workers from China, Java and India after the abolition

Past and Present

Monuments to and the remembrance of slavery including the question of historic responsibility

Does slavery still exist? Human rights

\section{In the Treasure chest}

Layout of a slave ship

chains

Slave bracelet uprising took place on in 1795 on Curaçao under the leadership of Tula, who, inspired by the ideals of the French Revolution and the success of the slave uprising in Saint-Domingue (Haiti), demanded freedom. Tula, however, paid for his freedom with his life.

At the end of the eighteenth century, outrage against the slave trade was growing. This was true in the Netherlands too, even though discussions were often dominated by the interests of slave owners. Under pressure from the English, the slave trade was prohibited in $\mathbf{1 8 1 4}$. In the Netherlands, the abolition of slave labour and slavery did not follow until 1 July 1863, making it one of the very last countries in Europe to emancipate its slaves.

\section{References}

Places to Go

Amsterdam: national slavery monument, Oosterpark Amsterdam or Middelburg: Slavery route

Amsterdam: National Institute for the Study of Dutch Slavery and its Legacy

Rotterdam: Rotterdam Historical Museum

\section{Books for young people}

Bené Alfonso, Medicijnmeester (14+)

Thea Beckman, Vrijgevochten (12+)

Harriet Beecher-Stowe, Uncle Tom's Cabin (12+)

Miep Diekmann, Marijn bij de lorredraaiers (14+)

Thea Doelwijt, o sekoer! Help!

Thea Doelwijt, "Nacht met mijn overoverovergrootmoeder" In: Ton van Reen, Ridders en Rebellen Mechtelly, Het meisje uit Tapoeripo Dolf Verroen, Slaaf kindje slaaf (10+)

\section{Background literature}

Bea Brommer (ed.), Ik ben eigendom van... Slavenhandel en plantogeleven, Wijk and Aalburg 1993

Rosemarijn Hoefte en Clazien Medendorp, Suriname, gezichten, typen en costumen naar de natuur geteekend door A. Borret, Leiden 2003

P.C. Emmer, De Nederlandse slavenhandel, Amsterdam/ Antwerpen 2003

\section{Websites}

www.slavernijmonument.nl www.ninsee.nl 


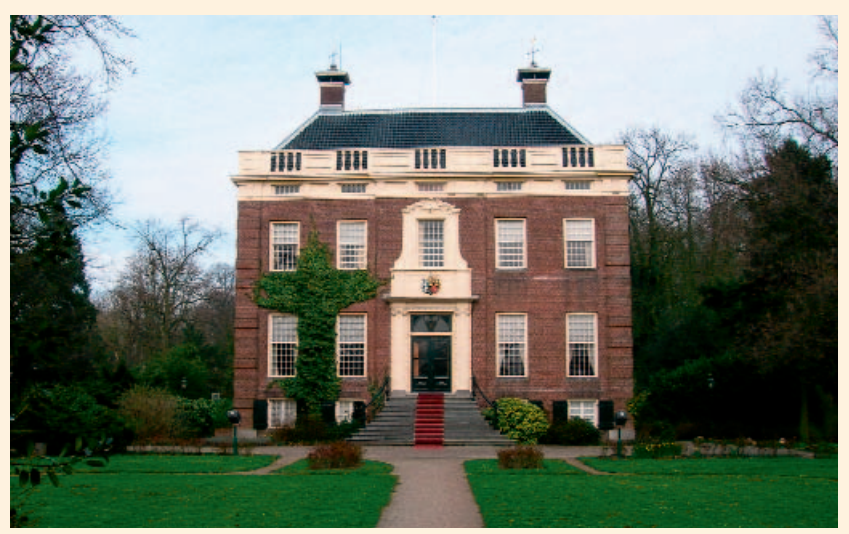

\section{Seventeenth and eighteenth centuries Country mansions Prosperous living in the countryside}

Today, Goudestein mansion is the town hall of Maarssen, situated to the north of Utrecht on the River Vecht. For a long time it had been one of many country mansions along the river where wealthy residents of Amsterdam came to spend the summer.

If you take a trip on or alongside the Vecht, you will come across a great many country mansions, real palaces with magnificent gardens. This concentration along the river illustrates the immense wealth of Amsterdam in the Golden Age. Most of the mansions were built in the seventeenth century, some later. Wealthy merchants liked to escape the town in the summer months and enjoy the natural surroundings along the Vecht. Such escapes went hand in hand with large-scale relocations, usually by barge. The staff were moved as well as part of the household stocks - everyone and everything was brought along. The men visited occasionally as they had to spend a lot of time working in town even over the summer months.
Goudestein is a textbook example of what happened to country mansions. In 1608, the Amsterdam merchant Jan Jacobszoon Huydekoper bought a large farmstead in Maarssen. His son Joan, a very important man in Amsterdam - he was, among other things, elected mayor on several occasions - subsequently had the Goudestein mansion built in 1628. In 1754 the seventeenth-century house was knocked down and replaced by the current palace. Up until the twentieth century the Huydekopers continued to live in the mansion. Then, in 1955, the municipality bought it and converted it into the town hall.

Influential people from Amsterdam invited many guests to their country retreats: friends from their social circles, as well as artists and intellectuals. The famous poet and scholar Constantijn Huygens stayed at Goudestein in $\mathbf{1 6 5 6}$ and apparently he enjoyed himself, for he wrote three spirited poems about the mansion.

The gardens of the houses were lovely and often still are today. They were 
inspired by the formal French style of landscaping, with tight geometric patterns. From this starting point, a new Dutch style evolved: ordered and geometric, but with baroque elements and playful additions like theekoepels (tea house gazebos), canals, water attractions and mazes. Needless to say, everyone wanted their garden to be a showpiece and each was more beautiful than the last.
The summer life in the country mansions of the aristocracy continued in the eighteenth century, although the economy in the Netherlands was slowing down. The wealthy families, however, were still able to live off their capital. Today, most of the country mansions are no longer owned by individuals. Instead they have become tourist attractions, prestigious business premises and venues for parties.

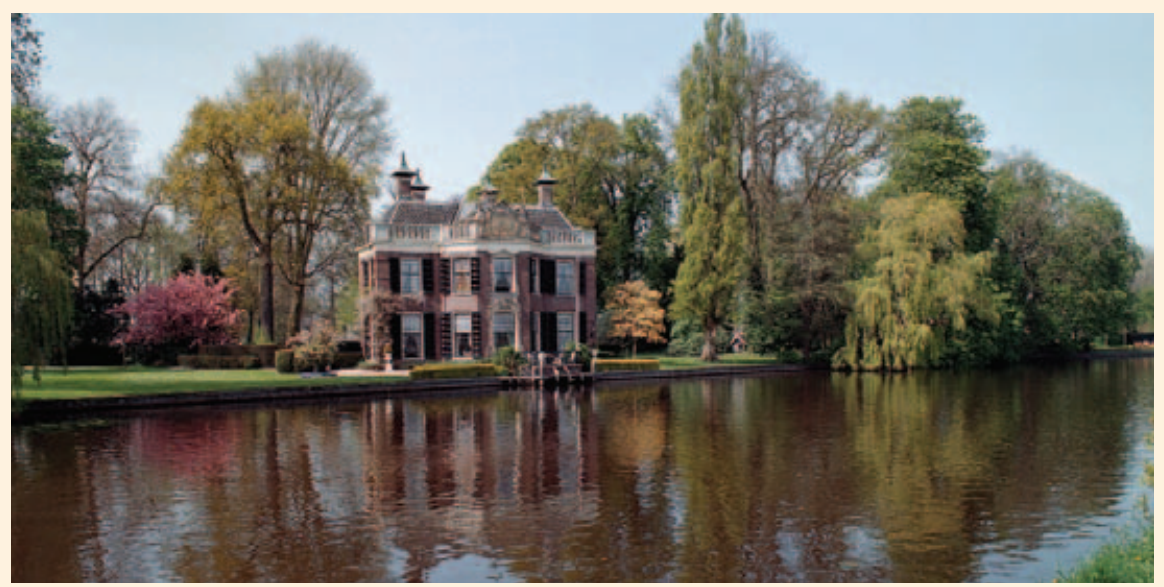

\section{Sub-topics}

\section{Primary education sector}

Barges, tea houses and chamber music

(Mozart in the Netherlands)

Gardens and parks, then and now

The Huydekoper family

\section{Secondary education sector}

The age of wigs

Inheritance in rural areas: country mansions and estates The bourgeoisie and the life of an aristocrat

The eighteenth century: the golden age of classical music History of interior design

\section{Past and Present}

How do the rich live? Signs of prosperity in the Netherlands.

Live off one's investments or continue to invest?

Chamber music today

In the Treasure chest

Wigs (men's and women's)

\section{References}

Places to Go

Maarssen: Maarssen Museum

Visit to country estates on the Vecht like Gunterstein, Vreedenhoff and Bijdorp

Visit to similar mansions in Kennemerland like Beeckestein

\section{Background literature}

M. Zeilmaker, Buitenplaatsen in Utrecht. Utrecht 2004 Joost Kloek en Wijnand Mijnhardt, 1800 Blauwdrukken voor een samenleving, The Hague 2001 Mozart \& de Lage Landen (audio book, double CD)

\section{Websites}

www.maarssen.nl www.beeckestijn.nl www.vecht.nl/index.php3?goto=7 www.belvedere.nu/page.php?section $=08 \varepsilon \mathrm{pID}=5 \& \mathrm{mID}=$ зदprID=201

www.collectieutrecht.nl/view.asp?type=thema\&id $=139$ www.cultuurwijzer.nl/cultuurwijzer.nl/cultuurwijzer.nl/ io00311.html 


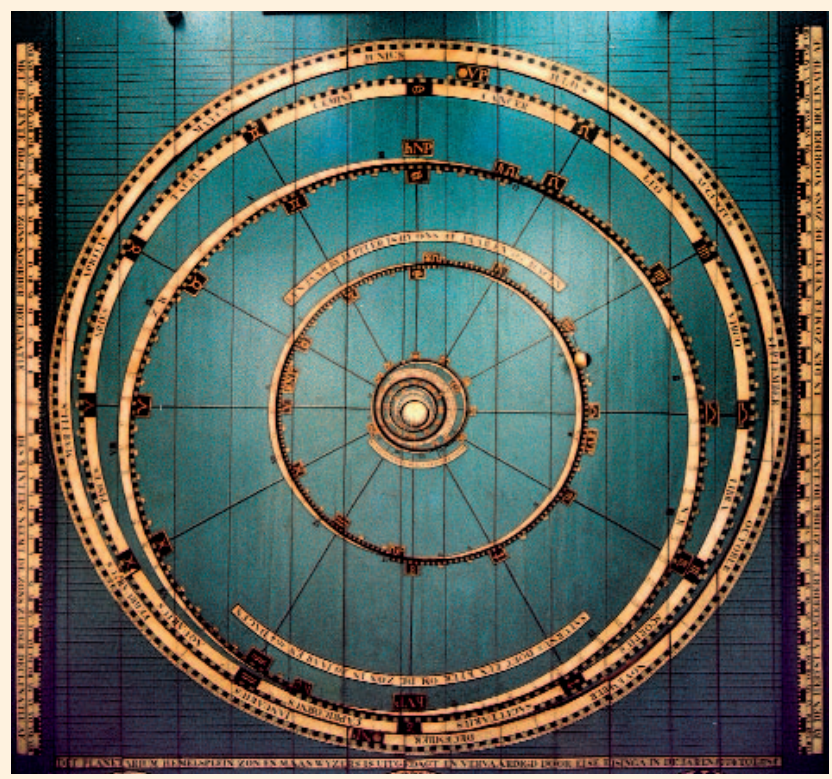

1744 - 1828

Eise Eisinga

The Enlightenment in the Netherlands

Eise Eisinga was an amateur astronomer who built a planetarium in his own home in Franeker (Friesland). Today this planetarium is recognised as the oldest in the world.

The highly gifted Eisinga was not allowed to attend the Latin School because he was expected to become a woolcomber like his father before him. All on his own, he immersed himself in the study of the principles of maths and astronomy. The fact that the Franeker Academy was close by suited him well.

In 1774, a booklet was published in which it was forecast that the earth would be thrown out of its orbit by a collision between the moon and a number of other planets. This prediction caused a great deal of panic in Friesland. To demonstrate that there was no need for panic, Eisinga decided to build a scale model of the solar system on the ceiling of his living room. In 1781 his planetarium was completed. Just like many other men of his time, Eisinga was inspired by the Enlightenment. These men were convinced that knowledge could improve both mankind and society. Enlightenment thinkers in the Netherlands were different in nature to those in France. Living in a country with no all-powerful church or absolute ruler meant that few Dutch citizens were sympathetic to the radical and anti-clerical views of some French philosophes. Rather, they believed that God wanted the best for the world: He was leading all things towards a friendly, harmonious society. They therefore immersed themselves in enjoyable social interaction. Together with other responsible citizens, they conducted 
experiments in physics, they examined fossils, discussed solutions for social problems and studied heavenly bodies.

Even today, Eisinga's planetarium shows the current position of the planets, because the planets of the model take the same time to move around the sun as do the real planets: Mercury takes 88 days for its orbit, Earth 365 days and Saturn over 29 years.

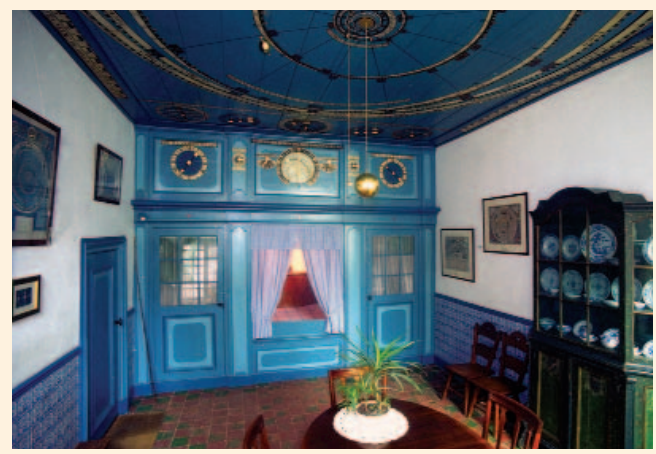

\section{Sub-topics}

\section{Primary education sector}

Boerhaave and medical science

The space voyages of André Kuipers and Wubbo Ockels Seeing is knowing: gaining knowledge through one's own observations

\section{Secondary education sector}

The Enlightenment in the Netherlands and France Electrostatic machine

Astrology, astronomy, the Big Bang

Science in society

Lorentz and other Dutch Nobel prize winners

\section{Past and Present}

Recent scientific findings

Science and space exploration

In the Treasure chest

Modern map of the skies
All this is kept in motion by an impressive gear mechanism of wooden rings and discs with ten thousand hand-forged nails as cog teeth. A pendulum clock and nine weights drive the gear mechanism.

When King William I came to Friesland in 1818 to visit the planetarium, he was so impressed that he subsequently bought it for the Dutch state. Ten years later, in 1828, Eisinga died aged 84 .

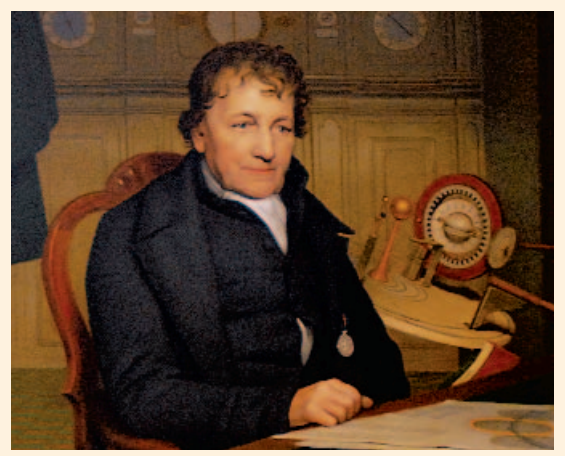

\section{References}

\section{Places to Go}

Franeker: Friesland Planetarium

Amsterdam: Artis Planetarium

Amsterdam: Nemo

Haarlem: Teylers Museum

The Hague: Omniversum

Leiden: Boerhaave Museum

Museums at universities

\section{Books for young people}

Piter Terpstra, Wolken en stjerren: roman oer Eise Eisinga

\section{Background literature}

H. Nieuwenhuis, Het Eise Eisinga Planetarium, Franeker 1988

Joost Kloek en Wijnand Mijnhardt, 1800 Blouwdrukken voor een samenleving, The Hague 2001

\section{Websites}

www.planetarium-friesland.nl

www.sterrenkunde.nl

www.allesoversterrenkunde.nl

www.proefjes.nl (brings children into contact with

empirical science in a fun way) 


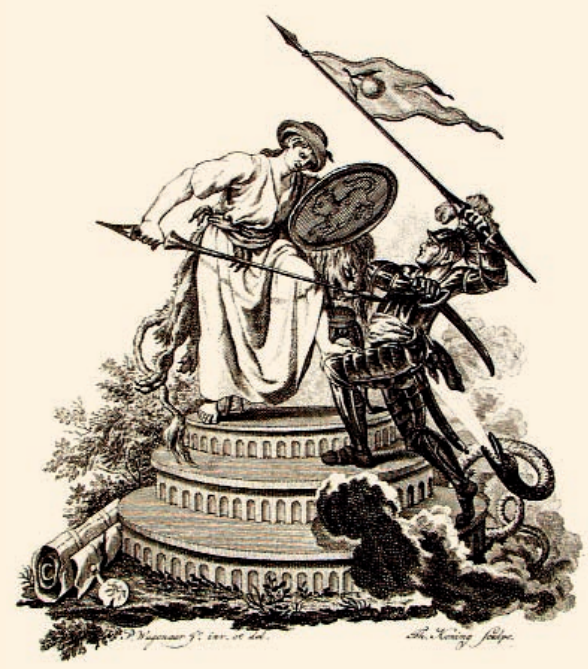

\section{$1780-1795$ \\ The patriots}

\section{Political conflict about modernising the Republic}

By the second half of the eighteenth century, the Golden Age of the Republic definitely seemed to be over. As a trading nation, the Republic had been surpassed by England. Although the financial sector was growing, it was unable to cope with increasing unemployment. The voice of the Republic was barely listened to in international politics. This was made painfully clear in the Fourth Anglo-Dutch War (1780-1784), in which the Republic could offer little resistance to the English.

A new political group came to the fore during this crisis. Citizens who up until then had had almost no say in the administration of the towns and the country itself. They regarded Stadholder (governor) William $\mathrm{V}$ as a kind of dictator and the ruling class as his puppets. They held the Stadholder responsible for the crisis in which the country found itself. These critical citizens called themselves the Patriots. Some members of the ruling class sided with the patriots.
On 26 September 1781, an anonymous, illegal patriot pamphlet was published, addressed "To the people of the Netherlands". It had an explosive effect on the political discussions. Two parties became clearly defined: the supporters of Stadholder William V, and, on the other side, the patriots. Both sides made full use of political pamphlets. The country was inundated by an avalanche of magazines - such as the influential De Kruyer - singlepage flyers and cartoons. All of these analysed how the Republic was organised and why it was failing, and put forward solutions. Gradually, new elements were brought into the discussions. This was the start of a national feeling, pride in one's own country, a feeling that began to play an increasingly larger role. People no longer simply thought of themselves as inhabitants of a town or region, but also as citizens of the fatherland, which, according to the patriots, should therefore be organised as a political unity. 
One moot point in this issue was how the citizens would be represented politically.

Patriot citizens organised themselves into 'vrijkorpsen', volunteer corps, a kind of militia to take over the country. Stadholder William V no longer felt safe in the patriot town of The Hague and he retreated to Nijmegen until the Prussian king sent in troops in 1787 to restore order.
The Prussian king's sister, Wilhelmina (wife of the Stadholder) had requested him to take this action. The patriot militia could not stand up to the well-trained Prussian soldiers. Eight years later (in 1795) the Republic came to its end after all, when the revolutionary French came to the aid of the (underground) patriots to overthrow the old regime.

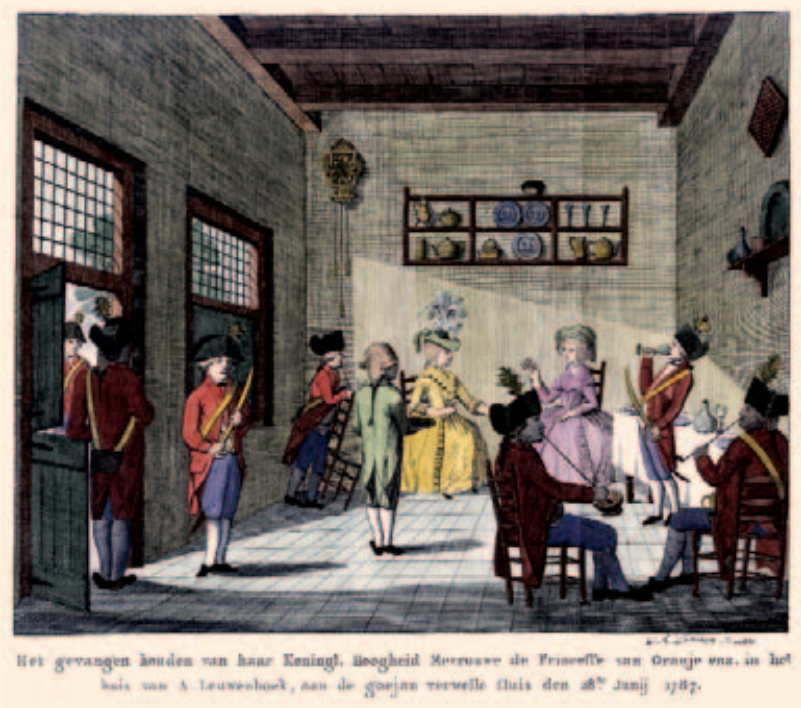

\section{Sub-topics}

\section{Primary education sector}

The patriot figure Joan Derck van der Capellen tot den Pol and the Orangist heroine Kaat Mossel Princess Wilhelmina stopped at Goejanverwellesluis The struggle for democracy

\section{Secondary education sector}

The end of the patriots in 1787 A century of democratic revolutions

The Society for Public Welfare and education for the people

Popular political ideas in the Enlightenment

The American War of Independence

\section{Past and Present}

Contemporary patriotism in the Netherlands and the US

In the Treasure chest

Replica of a patriot or Orangist pamphlet

Cartoon

Liberty cap

\section{References}

Places to Go

Amsterdam: Amsterdam Historical Museum Dordrecht: Simon van Gijn Museum-aan-huis

Books for young people

Theo Hoogstraten, De verdwenen grenadier (12+)

\section{Background literature}

Arie Wilschut, Goejonverwelles/uis: De strijd tussen patriotten en prinsgezinden, 1780-1787

(Verloren Verleden 9), Hilversum 2000

Simon Schama, Patriotten en Bevrijders: Revolutie in de Noordelijke Nederlanden 1780-1813, Amsterdam 1989

\section{Websites}

home.casema.nl/wilschut/ahvvn.htm (complete text of the 'To the people' pamphlet) 


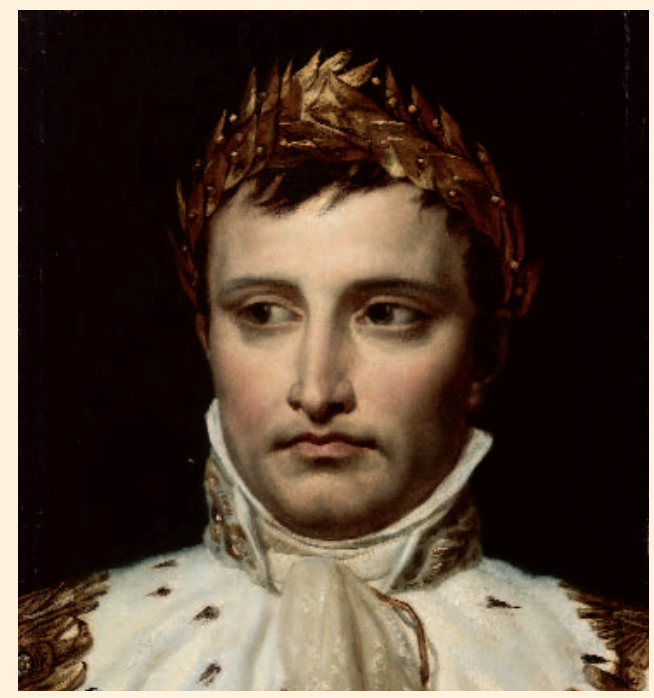

\section{$1769-1821$ \\ Napoleon Bonaparte}

The French period

The history of the Netherlands can never truly be separated from developments outside the country. This certainly applies to the end of the eighteenth century and the beginning of the nineteenth century, when the French exerted decisive influence on Dutch politics and the "little corporal” Napoleon Bonaparte was France's leader. Napoleon was a military man who overthrew the French government in 1799 and afterwards took control not only of France but also of all the territories conquered by French armies. Subsequently, as a general, he led his troops in battle against the Emperor of Austria, the Tsar of Russia and the King of England.

From 1806, Emperor Napoleon ruled almost the whole of Europe as an “enlightened despot”.

The Dutch Republic had already fallen to French troops in 1795 with the aid of Dutch patriots. Until 1806, the Batavian
Republic, as the Netherlands was then known, remained officially independent of France but in actuality little took place without the approval of the French. In 1806, Napoleon appointed his brother Louis as King of Holland, and the Netherlands became a kingdom. This laid the foundations for the later monarchy. In 1810 Napoleon deposed his brother and the Netherlands was absorbed into the French Empire. Three years later, Napoleon was defeated and banished to Elba; the Netherlands regained its independence.

Napoleon clearly played a leading role in the history of Europe at this time. One of his major achievements was that he modernised administration procedures and justice systems in the areas he controlled. He also implemented new weights (the kilogramme) and measurements (the metre). In addition, the registry of births, 
deaths and marriages was introduced whereby everyone had to adopt a surname.

The Dutch response to these modernisations was divided. For example, some believed that the Code Napoleon, the French civil code, was an enormous improvement compared to their own local laws. The new civil code created a rule of law under which everyone was equal, and in which the dispensation of justice was public. Its opponents felt that Napoleon had not taken into consideration the greatly varying local customs and arrangements. The introduction of conscription met with just as much resistance, especially when the demand for soldiers for the seemingly never-ending wars continued to grow.

After the fall of Napoleon no one thought about reversing the Napoleonic innovations. The Code Napoleon therefore remained in force, just like many more of Napoleon's innovations.

\section{Sub-topics}

\section{Primary education sector}

The French Revolution

From Little Corporal to Emperor and Ruler of the World Napoleon in Russia, Egypt and the Battle of Austerlitz 'I am your rabbit' (how Louis Napoleon made himself popular in the Netherlands)

\section{Secondary education sector}

The Dutch patriots and the fall of the Republic Louis Napoleon as King of the Netherlands The consequences of the Continental System for the Netherlands

The Battle of Waterloo

The map of Europe after the Congress of Vienna

\section{Past and Present}

The Palace on the Dam: royal palace and/or town hall? A French practice in the Netherlands: the population register

\section{In the Treasure chest}

Replica of a document from the registry of births, deaths and marriages

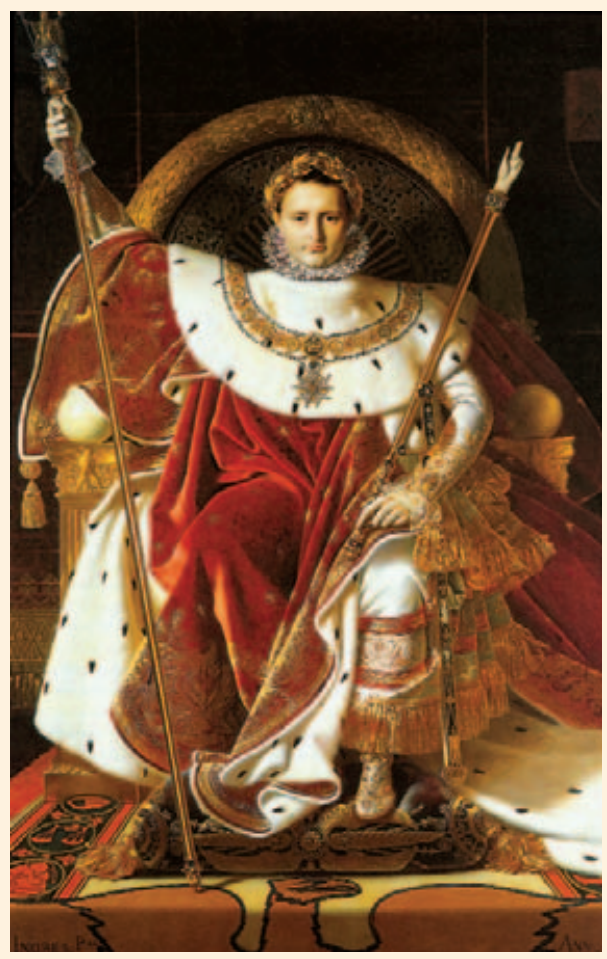

\section{References}

\section{Places to Go}

Amsterdam in the steps of Louis Napoleon: Palace on the Dam, Trippenhuis

Haarlem: The provincial government houses of the province of North Holland

Books for young people

Staton Rabin, Betsy en Nopoleon (12+)

\section{Background literature}

Judith Amsenga and Geertje Dekker, 'Wat nu?'

De Franse Tijd in Nederland, 1795-1813

(Verloren Verleden 23), Hilversum 2004

H.M. Beliën et al. (ed.) Nederlanders van het eerste uur: Het ontstaan van het moderne Nederland 17801830, Amsterdam 1996

Websites

mediatheek.thinkquest.nl

www.parlement.com 


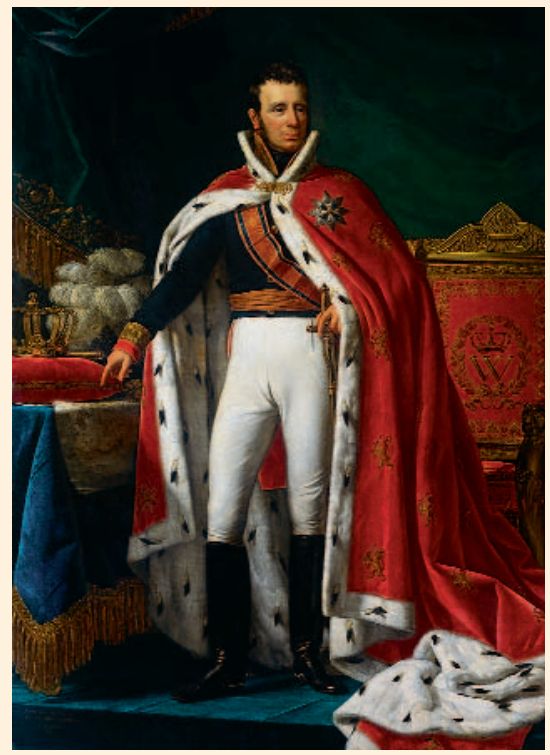

$1772-1843$

\section{King William I}

\section{The kingdom of the Netherlands and Belgium}

In 1813, after the end of French rule, the son of Stadholder William V returned to the Netherlands to accept the crown. This was a clear break with tradition. Unlike his father, William I did not become Stadholder (governor) of all the provinces but rather king of a unified state in which he played the main political role.

In 1815, the so-called Austrian Low Countries (modern-day Belgium) were united with the territory of the former Republic to serve as a buffer against the defeated French. And so, the United Kingdom of the Netherlands was created. In European terms it was a mediumsized country controlling large colonial territories. The energetic William (whose nickname was "king-merchant") tried to restore the previously thriving economy by stimulating its strengths in the three parts of the country (the north, south and the Indies). The south, where an Industrial Revolution had taken place early, had to concentrate on producing consumer goods. The traders in the north subsequently had to transport these goods across the world. And finally, the inhabitants of the colonies were to supply valuable tropical goods. The King had canals dug and roads laid between the north and south to make transport more easy. He himself acted as an investor. In 1824, William set up the Netherlands Trading Company for trade with the Dutch East Indies. The "cultivation system" or "culture system" was introduced in the East Indies, under which the indigenous population was obliged to work for the colonial authorities on the land for a period of each year. The products were sold by the Netherlands Trading Company. 
Despite his economic endeavours, the King was not popular among the Belgians. Belgian liberals saw him as a ruler who desired absolute power and who was not prepared to tolerate any increased participation on the part of the educated elite. Belgian Catholics objected to the interference of the Protestant king in the training of novice priests. In 1830, the citizens of Brussels rebelled. They were inspired by the aria “Amour sacrée de la patrie" that had been sung in their theatre. William I sent an army against them but to no avail. Belgium was granted independence. Nevertheless, William I kept the army called up for nine years - incurring extremely high costs something that damaged his reputation in the Netherlands very badly. In 1839 he finally recognised Belgium's independence. In the following year, a disillusioned William I abdicated from the throne.

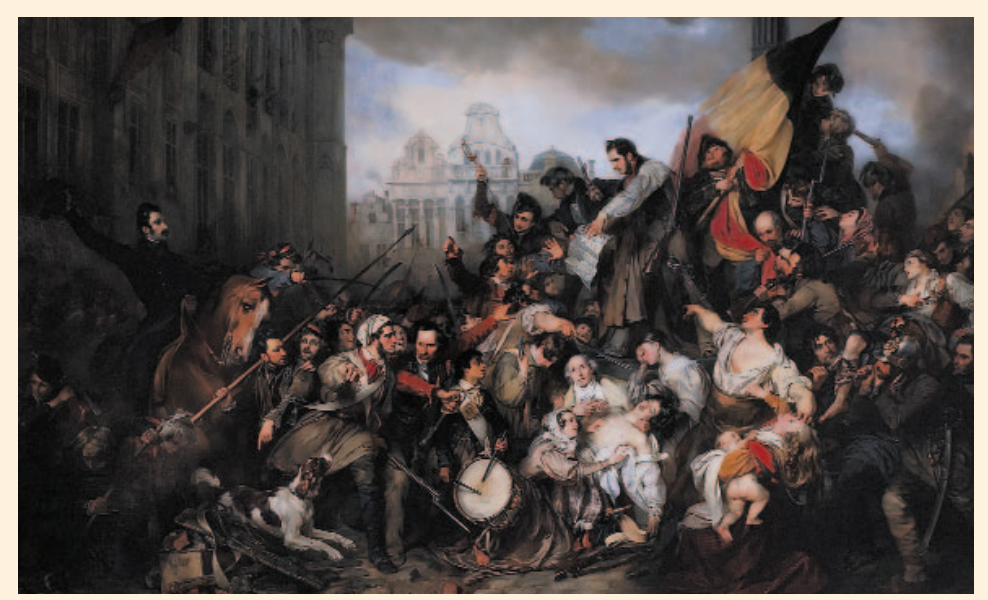

\section{Sub-topics}

\section{Primary education sector}

Symbols and rituals surrounding the monarchy

William I, king-merchant

The Belgian rebellion (theatre, Jan van Speyck:

"then I'd rather blow up")

\section{Secondary education sector}

The development of the position of the monarch in

Dutch constitutional law

The colonial politics of the Netherlands

Potgieter and loss of direction (Jan Saliegeest)

International relations in Europe in 1830:

Congress of Vienna

The borders of 1839

\section{Past and Present}

The monarchy: its significance, pros and cons

Relations between Netherlands-Belgium and Flanders

In the Treasure chest

Family tree of the House of Orange

\section{References}

Places to Go

Amsterdam: Palace on the Dam

Frederiksoord

\section{Books for young people}

Martine Letterie, Ver van huis (10+)

\section{Background literature}

Frits Rovers, 'Dan liever de lucht in': Jan van Speijk en de Belgische Opstand. (Verloren Verleden 12), Hilversum 2000

Maartje Janse, De geest van Jan Salie: Nederland in verval? (Verloren Verleden 17), Hilversum 2002

Thomas von der Dunk, "Amsterdam: het Paleis op de Dam" in Jan Bank and Marita Mathijsen, Plaatsen van herinnering: Nederland in de negentiende eeuw, Amsterdam 2006

\section{Websites}

www.bmz.amsterdam.nl/adam/nl/groot/paleis.html www.anno.nl/anno/anno/io01589.html 


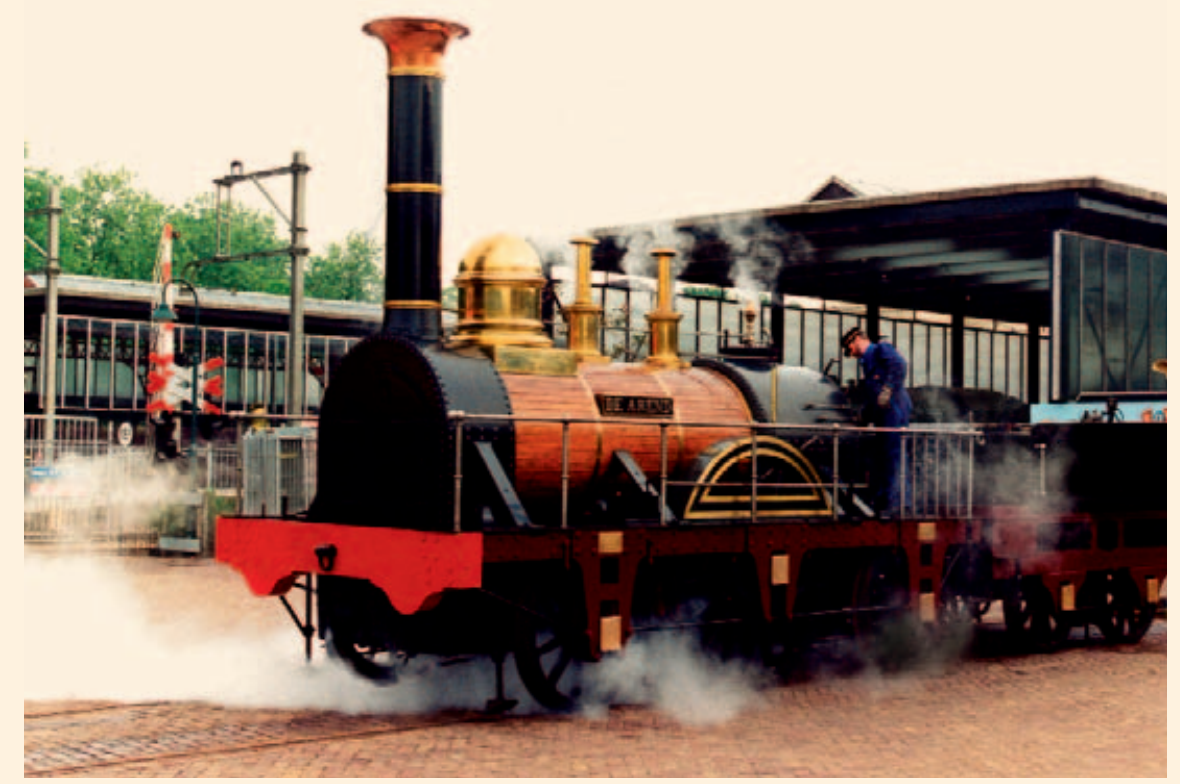

1839

The first railway

Acceleration

On 20 September 1839, the first railway line in the Netherlands was opened with a festive celebration. The steam locomotive "De Arend" took twenty-five minutes to travel from Amsterdam to Haarlem. A lot of people were not impressed: the train went too fast and made much too much noise. Was this novelty really necessary and was it safe? Near Ghent at the beginning of the same year, the steam boiler of a departing train had exploded. This innovation was doomed to failure and after all, barges were a fine mode of transport, weren't they?

Despite all the initial scepticism, the first train heralded a time of enormous change. The Amsterdam-Haarlem line was quickly extended into what became known as the "Old Line" running from Amsterdam to Rotterdam. Work on the second major rail link began in 1843 , connecting Amsterdam with Utrecht. More lines followed, all run by different railway operators. By about 1900, the train had become the most important mode of transport in the Netherlands.

Today, it is hard to imagine the enormous changes the railways brought about in Dutch society. Before the arrival of the railways, travelling cost a great deal of time. It was too expensive for most people and was sometimes dangerous. In terms of travelling time, the railways made the Netherlands much smaller. The improved links and travel comfort contributed greatly to the unification of the country: people from different regions came into contact with one another more often and the state was able to better organise its national territory. 
The railway network was a pre-condition for the industrialisation of the Netherlands, which only really took off after 1870. Raw materials, products and workers too all had to be transported. In its turn, industrialisation contributed to the further expansion of the railway network. At the beginning of the twentieth century, the Netherlands had a dense railway network. In the thirties, however, many lines were closed - particularly local ones. In 1938, all the lines were incorporated into one nationalised company: NV Nederlandse Spoorwegen (NS) that continued to exist until the reorganisation of 1995. The state and all kinds of lobby organisations are still actively involved in the now privatised NS and its services. This indicates that railways have remained a vital component of Dutch society.

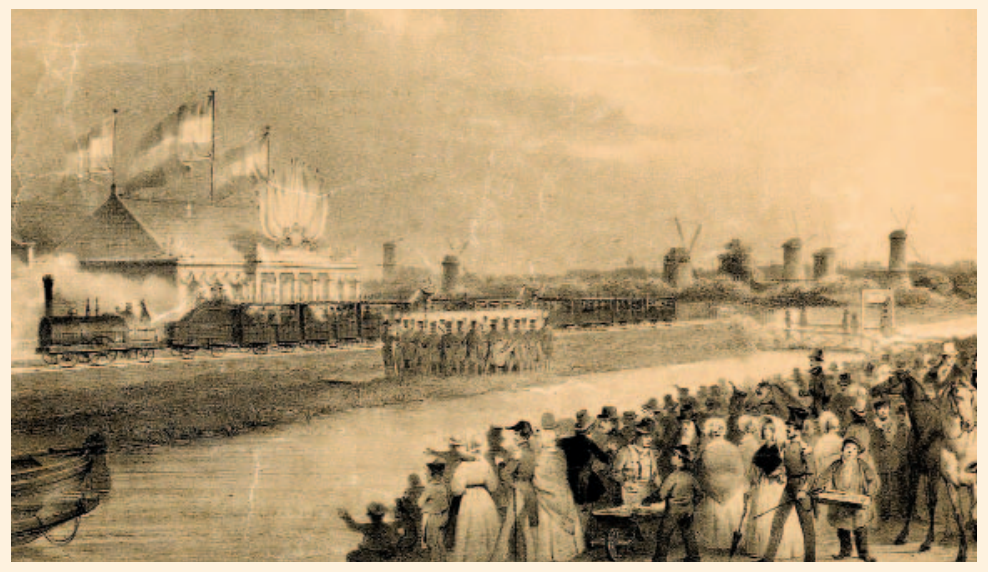

\section{Sub-topics}

\section{Primary education sector}

Traffic and transport (from barges to trains and further) Steam engines and steam trains

\section{Secondary education sector}

Infrastructure in the Netherlands, also from the

European perspective

The English Industrial Revolution

The industrialisation of the Netherlands

Mobility issues

\section{Past and Present}

What are the advantages and disadvantages of public transport versus private transport?

Railways today (compare nineteenth-century and modern-day travelling times)

The Netherlands: from trading nation to industrialisation and back again?

In the Treasure chest

An old model train, preferably "De Arend"

The first Amsterdam-Haarlem ticket

Steam engine

\section{References}

Places to Go

Utrecht: Spoorwegmuseum

Utrecht: Mobilion

Brussels: Belgian Railways Museum

\section{Books for young people}

Arend van Dam, Complot op het spoor $\left(9^{+}\right)$

\section{Background literature}

Guus Veenendaal, "Haarlem: Centraal Station. De eerste spoorweg in Nederland" in Jan Bank and Marita Mathijsen, Plaatsen van herinnering. Nederland in de negentiende eeuw, Amsterdam 2006

\section{Websites}

www.kinderpleinen.nl/spoorwegen.html www.spoorwegen.startkabel.nl/k/spoorwegen/ index.php?nr=1

www.ns.nl 


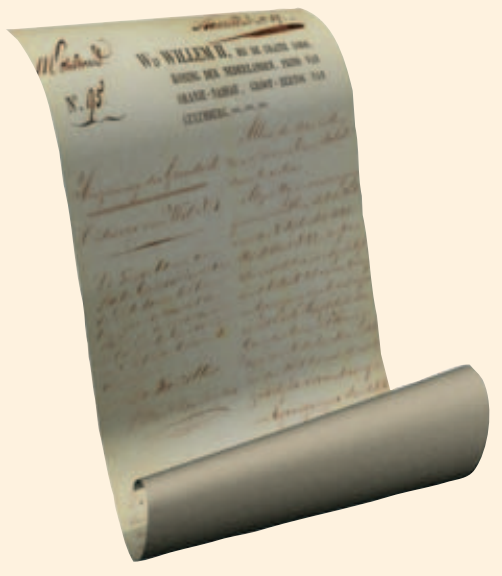

\section{8 \\ The Constitution}

\section{Fundamental rules and principles of government}

The Constitution is the most important law of a state. (The word "state" refers to an autonomous territory in which power is exercised over the inhabitants.)

The Constitution determines who exercises power in practice in such a state and how this will take place. The Dutch Constitution sets out, for example, the role of the monarch and that of the ministers. The Constitution also states how other laws are to be made, what duties judges have and what the tasks of the municipalities and provinces are. Moreover, the Constitution sets out what influence and power Dutch citizens have in the state.

Right at the beginning, the Dutch Constitution sets out the rights of citizens in terms of the state: basic rights. Basic rights are not the rights of citizens amongst one another but rather the rights of citizens to live their own lives without the interference of the state in their opinions and life choices.

The first article of the Constitution promises that all people, no matter how different they are or what different opinions they hold, will be treated equally by the state. In the articles that follow, the Constitution states, among other things, that citizens have the right to practice their own religion, the right to exchange ideas with one another; and the right to express their opinions in public.

The state can only restrict such rights like freedom of worship and freedom of speech - if it is absolutely necessary. For example, someone's freedom may be restricted if that person presents a danger to others. In such instances the state may act, but only in accordance with the law.

No Constitution existed in the Netherlands in the Middle Ages. The ruler had the power and did not have to conform to the law. In later times, some groups of people did gain rights in respect of their ruler, but it was only from the eighteenth century onwards that everyone had rights and that every institution entitled to exercise power was obliged to obey the law. This was set down in a Constitution in the 
Netherlands in 1798. The "Constitution of the Kingdom of the Netherlands" that still applies today was drafted in $\mathbf{1 8 1 5}$.

It is easier to change other laws than it is to change the Constitution. However, significant amendments to the Constitution have been made. In 1848 King

William II agreed to amend the Constitution so that the monarch would have less power and the people more. This amendment was so dramatic that the "Constitution of 1848 ", drafted by constitutional law expert Thorbecke, is regarded as the beginning of democracy in the Netherlands. Nonetheless, it was only in 1917 that the right to vote was extended to include all men. Women were granted the passive right to vote at the same time. In 1922, the active right to vote for women - that was introduced in 1919 - was finally set down in the Constitution.

\section{Sub-topics}

\section{Primary education sector}

Equality and non-discrimination

Freedom of speech and freedom of worship

The duties of the monarch

\section{Secondary education sector}

Separation of powers: the division of power across various state bodies

The difference between classic basic rights and social basic rights

Constitutional conflict: for example between freedom of worship and freedom of speech

The non-discrimination principle of Article 1 of the Dutch Constitution. Equality under the law guarantees citizens the freedom to be different and still be treated equally by the state.

Relationship to international law: constitutional freedoms guaranteed under human rights treaties

\section{Past and Present}

Forming a government today after elections

In what kind of discussions do people still invoke the Constitution?

The Universal Declaration of the Rights of Man

In the Treasure Chest

A copy of the current Constitution

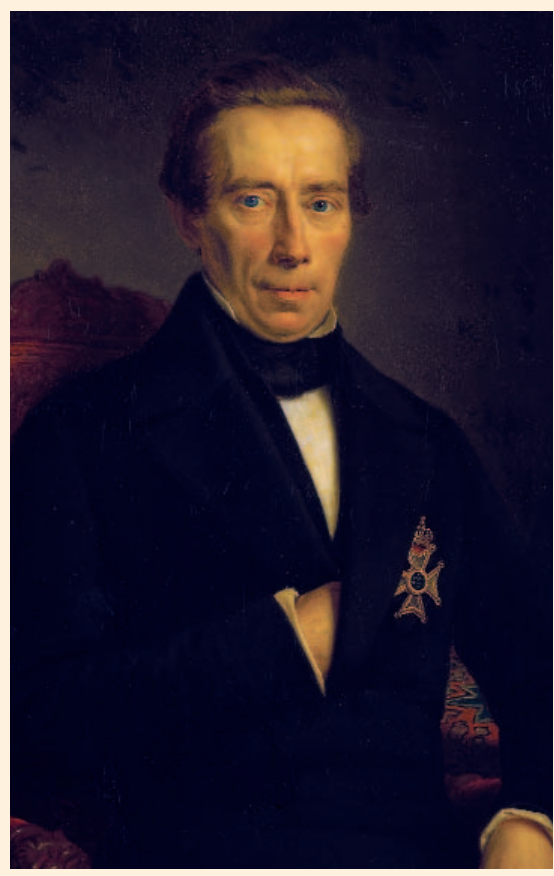

\section{References}

\section{Places to Go}

Visit to the Lower House of the Dutch Parliament

Visit to a Court

Visit to a municipal council

\section{Background literature}

Jan Drentje, "Den Haag: het Plein. De grondwetswijziging van 1848 , liberaal onder Oranjes hoede" in Jan Bank and Marita Mathijsen, Plaatsen van herinnering. Nederland in de negentiende eeuw, Amsterdam 2006

De Grondwet van Nederland, with a foreword by H.D. Tjeenk Willink and an introduction by Henk te Velde

\section{Websites}

wetten.overheid.nl/cgi-

bin/deeplink/law1/title=GRONDWET

www.parlement.com/9291000/modulest/gczvv5nv 


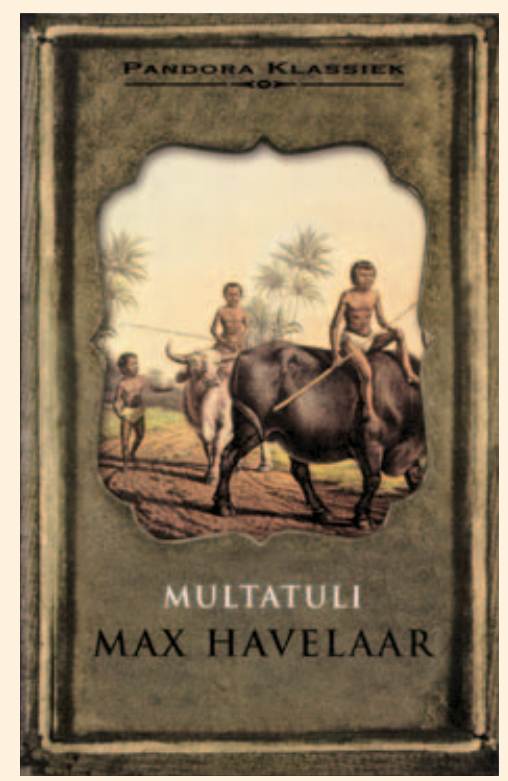

1860

\section{Max Hovelaar}

\section{Scandal in the East Indies}

In 1859 Eduard Douwes Dekker, a disappointed civil servant in the Dutch East Indies, wrote a book under the pseudonym "Multatuli". This book was entitled "Max Havelaar or the Coffee Auctions of the Dutch Trading Company”. It was a condemnation of the abuses of the Dutch colonial administration in the Dutch East Indies.

The book is a frame story with various interwoven storylines. It begins with the tale of Batavus Droogstoppel, a coffee broker and textbook example of a petty bourgeois, unimaginative, miserly man who symbolises how the Netherlands was profiting from its colonies in the East Indies. On a certain day, a former classmate (Sjaalman) visits Droogstoppel and asks him to publish a manuscript.

What follows - interrupted by Droogstoppel's commentary - is the tale of the manuscript that relates in broad lines the actual experiences of Multatuli (alias Max Havelaar) as assistant-resident in the Dutch East Indies. (This is largely history as experienced by the writer Eduard Douwes Dekker himself as a civil servant.) Assistant-resident Havelaar takes up the cause of the oppressed islanders, the Javanese, but his Dutch superiors and local profiteers who do business with the Dutch work against him.

A number of native stories are woven into the book, for example, the story of Saidjah and Adinda. Between the lines of this moving love story lies a bitter indictment of the exploitation and cruelties to which the native Javanese were subjected. At the end of the book, Multatuli addresses a passionate plea directly to King William III, who, as head of state, was ultimately responsible for the abuses and corruption 
of the administration in the Dutch East Indies.

Initially, the book received a lot of criticism, but it quickly created a storm and was reprinted many times. It is still in

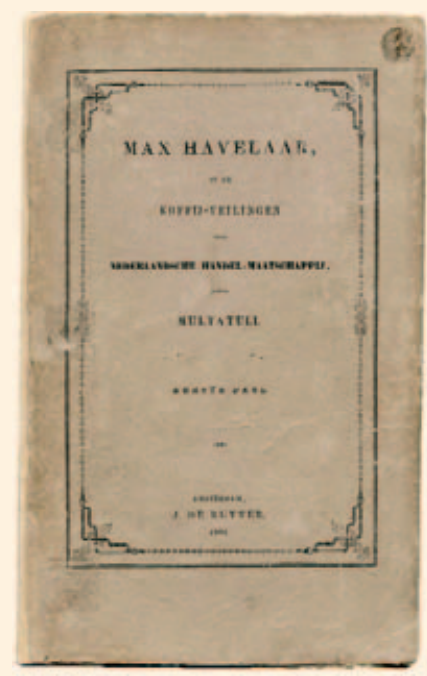

\section{Sub-topics}

\section{Primary education sector}

The lives of the Dutch in the Dutch East Indies

The life story of Multatuli (including "Woutertje Pieterse", with its wonderful classroom scenes)

The cultivation of rice in Indonesia

\section{Secondary education sector}

The rise and fall of the "cultivation system" (or "culture system")

The character of Batavus Droogstoppel as a typical Dutchman

Adat law

A rhetorical analysis of Max Havelaar's speech to the indigenous chiefs of Lebak

The Netherlands as coloniser compared to England and France

\section{Past and Present}

What is the Max Havelaar Foundation attempting to achieve? Is the choice of this name justified?

Folk stories from different cultures (further to the story of Saidjah and Adinda)

In the Treasure chest

A copy of "Max Havelaar"

Rice, sugar and tea from Indonesia print today and has been translated into over 140 languages. In 1999, the Indonesian writer Pramoedya Ananta Toer referred to the book in The New York Times as "The Book That Killed Colonialism".

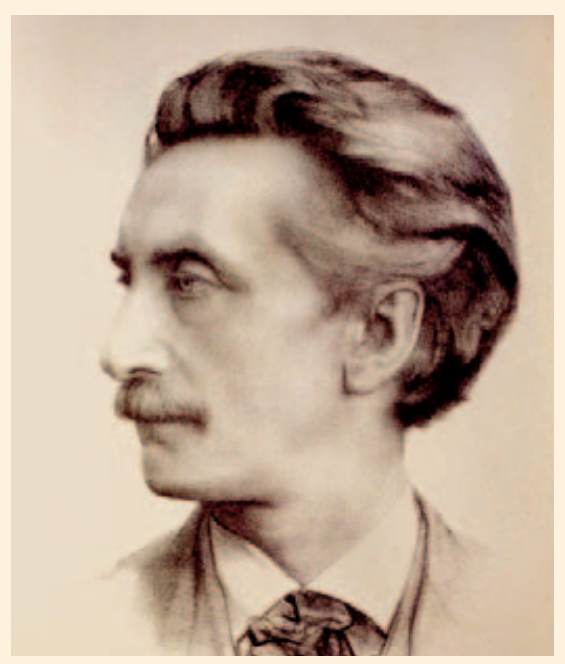

\section{References}

Places to Go

Amsterdam: Multatuli Museum

Amsterdam: Tropenmuseum

Books for young people

Multatuli, Saïdjah en Adinda (Ad Jonker edition)

Multatuli, Woutertje Pieterse

\section{Background literature}

D. van der Meulen, Multatuli: Leven en werk van Eduard Douwes Dekker, Amsterdam 2002

Hella S. Haasse, Bij de les: Schoolplaten van

Nederlands-Indië, Amsterdam/Antwerpen 2004

\section{Websites}

www.multatuli-museum.nl/multatuli/index.html

(featuring the article by Pramoedya in The New York Times)

www.iisg.nl/bwsa/bios/douwes-dekker.html 


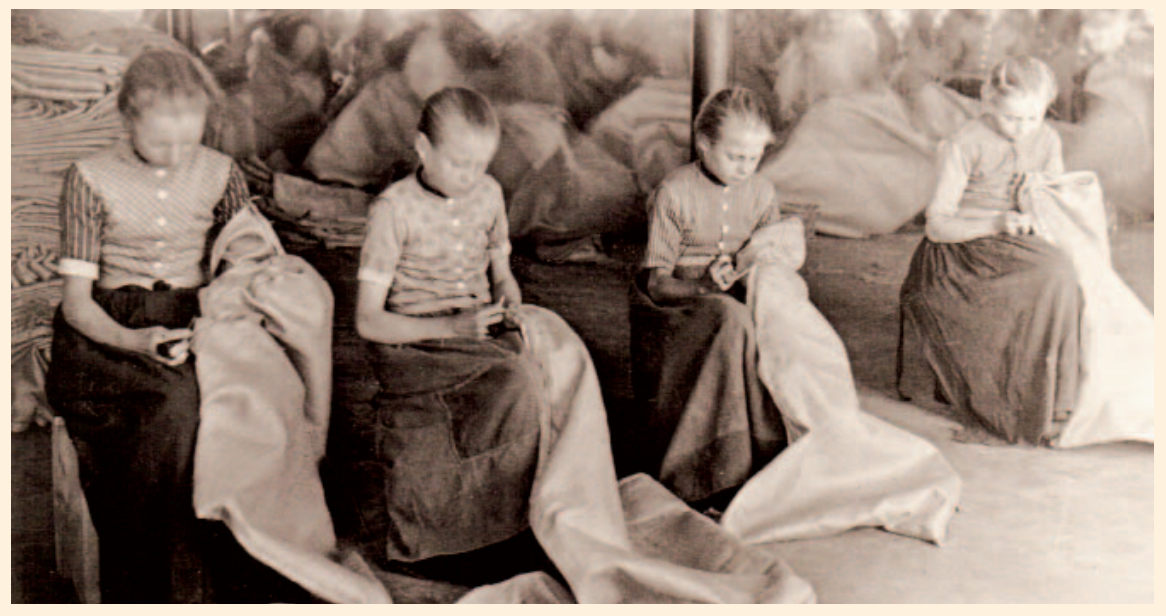

\section{Nineteenth century Opposition to child labour} Out of the workplace and back to school

Child labour was a normal and usual occurrence in the nineteenth century. Children worked on the land and in shops or workshops. This was considered very sensible - they could learn a trade in this way - but often it was necessary for children to work to supplement the family income. When, during the Industrial Revolution, children were put to work in factories as well, more and more objections were raised against child labour - at least in factories.

Working conditions in factories were usually very poor. A well-known story is that of Petrus Regout's glass factory in Maastricht, where the kilns burned day and night. The factory had two shifts of workers, each working twelve hours at a stretch. Half-asleep, children aged between eight and ten years old would have to walk to work at about midnight to start their shift. Regout saw no problem in this. He believed that children could do with less sleep.
In about 1860 , criticism of child labour became more intense. Doctors and teachers explained that working was unhealthy and that the proper place for children was at school. Factory operators began to realise that children would be better off starting work once they had completed their primary education. Moreover, children aged twelve years and older who could read and write could be put to better use in the factories. At the same time, the need for child labour decreased as increasingly more work was done by machines. The attitude of parents also began to change with the times. As their wages began to rise and the need to supplement their income with their children's wages became less pressing, parents started to send their children to school more often and for longer periods of time.

Two Acts contributed to this development. The Kinderwet van Van Houten (the Child Labour Act of 1874) prohibited 
children under the age of twelve from working in workshops and factories. This did not mean, however, that child labour in factories was fully abolished with immediate effect. Furthermore, children were not prohibited from doing farm work. The Leerplichtwet (Compulsory Education Act of 1900) put an end to child labour once and for all. From that time onwards, parents were obliged to send children aged between seven and twelve years old to school. In practice, most parents were already doing so. By about 1900, ninety percent of all children were attending school.

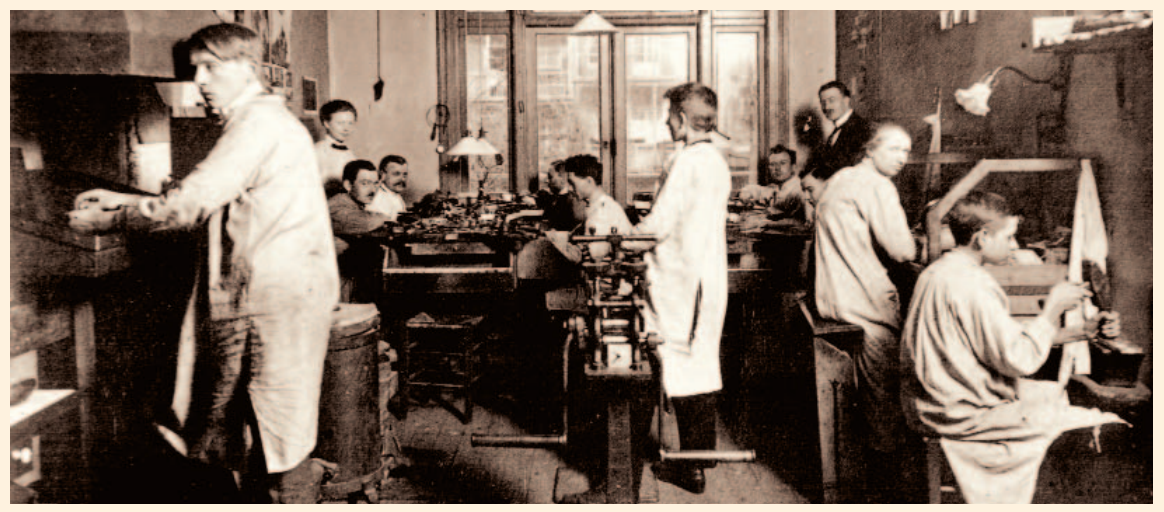

\section{Sub-topics}

\section{Primary education sector}

Children as factory workers (only one hundred years ago)

The way of life at the bottom of society in the nineteenth century

Improvements in primary education in the nineteenth century

\section{Secondary education sector}

The novel (condemnation) Fabriekskinderen

by J.J. Cremer

Industrialisation in the Netherlands compared to countries like Belgium and England

Charles Dickens

school-funding controversy, relating primarily to the equal treatment in financial terms of private and state schools

Social legislation in the Netherlands in the long term

\section{Past and Present}

Child labour today in Third-World countries

In the Treasure chest

Nineteenth-century primer or writing materials that were used in primary schools

\section{References}

Places to Go

Leiden: the Lakenhal Museum

Losser: Grenshistorisch Smokkel- en Textielmuseum

[historical smuggling and textile museum in a border region]

Rotterdam: National Museum of Education

Arnhem: Open-air Museum

\section{Books for young people}

Catherine Chambers, Kinderarbeid (10+ info)

Martine Letterie, Opa Sigaor (8+)

Martine Letterie, Broer in de fabriek (8+)

\section{Background literature}

Willemien Schenkeveld, Het kinderwetje van Von Houten. (Verloren verleden 22), Hilversum 2003 Willemien Schenkeveld, "Maastricht: de fabrieken van Petrus Regout: Kinderarbeid en de wet-Van Houten" in Jan Bank and Marita Mathijsen, Plaatsen van herinnering: Nederland in de negentiende eeuw, Amsterdam 2006

\section{Websites}

www.schooltv.nl/vroegerenzo [child labour] www.kennisnet.nl/po/leerkracht/perdagwijzer/

kinderarbeid

www.onderwijsmuseum.nl 


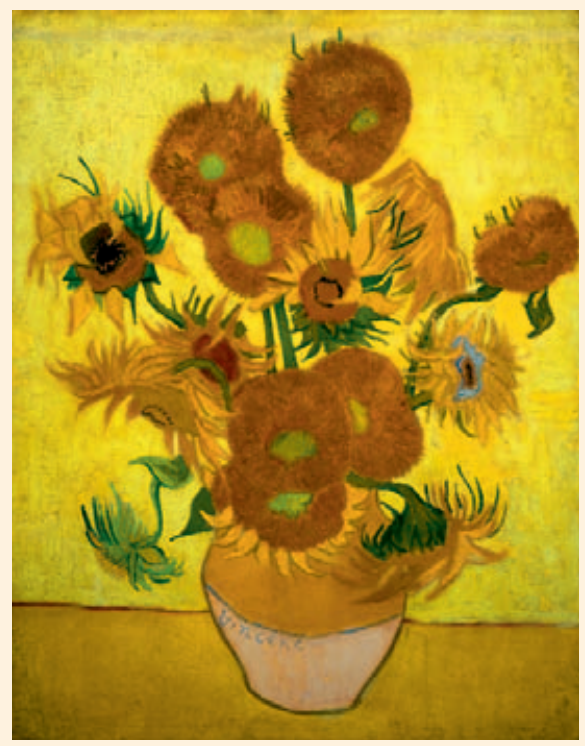

\section{$1853-1890$ \\ Vincent van Gogh \\ The modern artist}

Every year, some one and a half million people visit the Van Gogh Museum in Amsterdam. Eighty to ninety percent of these visitors come from outside the Netherlands. The Dutch painter Vincent van Gogh is famous in all four corners of the globe.

This was not the case in the nineteenth century during his lifetime. Van Gogh had a difficult life filled with upheaval, lost loves and financial problems. Despair ultimately drove him to commit suicide. Only after his death did his star begin to rise. On the one hand, this was because of his paintings: powerful images, with vibrant colours, different. Many people of all ages appreciate his work. On the other hand, people are interested in Van Gogh's life story. His is the textbook tale of the artist whose genius is only matched by his loneliness.
Van Gogh was born in 1853 in the village of Zundert in the province of Brabant. At a young age he travelled across the Netherlands and Europe. In 1885, in Nuenen, he painted the famous picture “The Potato Eaters", a dark portrait of a peasant family. The following year he went to Paris. Van Gogh's brother Theo, an art dealer in Paris, showed him paintings and drawings of the Impressionists, artists whose use of colour and light was more refined than what Vincent was used to. Vincent was also impressed by the Japanese prints he viewed.

In 1888, he rented a studio in the south of France: the "Yellow House" in Arles. He wrote to his younger sister Wil that the lavish natural beauty of the south demanded a new way of painting: "Distinctly colourful: sky blue, pink, orange, vermillion, bright yellow, 
bright green, bright wine-red, violet”. Vincent painted landscapes and, because he could not afford to pay for models, many self-portraits.

The French artist Paul Gauguin came to stay with Vincent, but they had an argument. Van Gogh became so confused that he threatened Gauguin with a razor. Shortly afterwards Van Gogh cut of a portion of his left ear, either accidentally or on purpose. Some of his self-portraits show him with his ear bandaged.

Van Gogh became increasingly neurotic and had himself committed to a psychiatric

\section{Sub-topics}

\section{Primary education sector}

The development of Van Gogh's work based on several paintings

Colours and their effect

Appreciation of Van Gogh in the Netherlands and elsewhere today

\section{Secondary education sector}

The influence of Vincent van Gogh and what influenced him

The Hague School

Photography and painting

The Eighties Movement

Art and the market (collectors since Theo, museums, art dealers, auction houses)

\section{Past and Present}

What does "beautiful" mean in the sentence: I think Van Gogh's sunflowers are beautiful?

The place in China where copies of Van Gogh's works are mass-produced ("Van Gogh from the sweatshop": Spiegel online, 23 August 2006)

The market value of Van Gogh, museums and private collectors

\section{In the Treasure chest}

Cube with paintings of Van Gogh

Replica of a letter to his brother Theo institution where he painted his famous cypresses and starry skies. On 27 July 1890 he walked into a corn field and shot himself in the chest. He died two days later.

Today, Vincent van Gogh is such a highly appreciated artist that his work hangs in museums throughout the world and is worth huge amounts of money. His portrait of the owner of the cafe in Arles, “L'Arlésienne”, was auctioned in New York in 2006 for 40.3 million dollars (33.9 million euros). That is the equivalent of the price of a Boeing 737 commercial airliner.

\section{References}

Places to Go

Amsterdam: Van Gogh Museum

Otterlo: Museum Kröller-Müller

Maastricht: Tefaf

The Hague: Panorama Mesdag

\section{Books for young people}

Ceciel de Bie, Mijn broer Vincent van Gogh:

Een kunstboek voor kinderen over Theo en

Vincent van Gogh. Zwolle: Waanders, 2002

Frank Groothof, "Vincent en Theo, broeders in de kunst". An introduction to Vincent van Gogh and his brother Theo, the Van Gogh Museum and the collection. For primary school, years 4-6. Orders can be placed with the Education Department of the Van Gogh Museum: email onderwijs@vangoghmuseum (10+ info)

Sean Connolly, Het leven en werk van Vincent van Gogh (7+ info)

\section{Background literature}

Leo Jansen, "Nuenen: Gerwenseweg 4. Vincent van Gogh schildert de aardappeleters" in Jan Bank and Marita Mathijsen, Plaatsen van herinnering: Nederland in de negentiende eeuw, Amsterdam 2006

H. van Crimpen and M. Berends-Alberts (ed.), De brieven van Vincent van Gogh, The Hague 1990

\section{Websites}

www.kmm.nl (Kröller-Müller Museum) www.vangoghmuseum.nl www.vggallery.com/international/dutch (complete works) www.vangoghzundert.nl (birth place) 


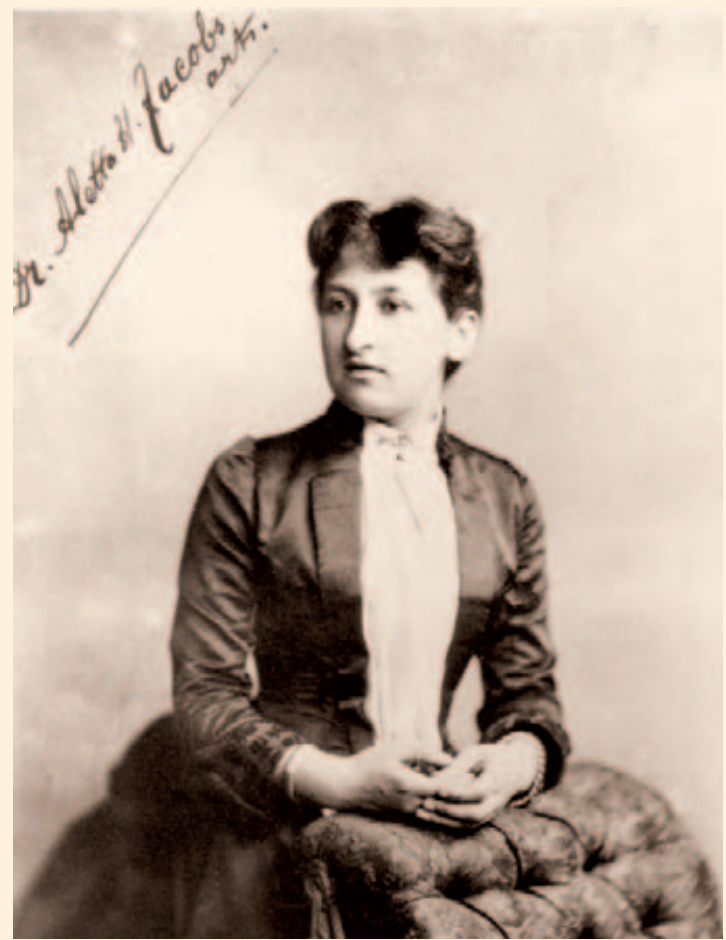

\section{$1854-1929$ Aletta Jacobs The emancipation of women}

Aletta Jacobs was the first woman in Dutch history to be officially admitted to university. This took place in $\mathbf{1 8 7 1 .}$ As a schoolgirl she had written a letter to Prime Minister Thorbecke requesting permission to be allowed to attend "academic classes”. Aletta Jacobs' dream was to become a doctor. Thorbecke answered within a week, but did not write to Aletta herself. Instead, he wrote to her father that permission had been granted. And so, thanks to a seventeen-year-old girl, in 1871 universities in the Netherlands were opened to women. Prior to this time, universities and most schools as well were only open to young men. Only Anna
Maria van Schurman, an educated woman (she had a command of no less than ten languages) who lived in the seventeenth century, had ever been allowed to attend any lectures (in Utrecht). However, she had had to sit behind a curtain so as not to cause a distraction for the young men.

Throughout her life, Aletta Jacobs fought for the rights of women. As a doctor, for example, she opened a practice that assisted women with contraception so that they did not have to become pregnant every year. She also fought against the abuses of the retail trade. In her practice in Amsterdam, she had noticed that shop girls suffered from many physical 
complaints because they were forced to remain standing for the entire working day (which was then eleven hours long). Thanks to Aletta Jacobs, a bill was passed that obliged shops to provide their staff with seating facilities. For fifty years, Aletta Jacobs also fought for the right to vote for women, together with other men and women who supported the rights of women. These women called themselves "feminists" and made their voices heard in a variety of ways: they organised exhibitions, published newspapers and pamphlets, established societies, held demonstrations and submitted petitions. However, it was only in 1919 that the right to vote for women was introduced in the Dutch Constitution. In 1922, Dutch women voted for the first time. Aletta Jacobs was 68 years old at the time.

\section{Sub-topics}

\section{Primary education sector}

Famous women from Dutch history like Jacoba van Beieren, Kenau Simons Hasselaar, Anna Maria van Schurman, Betje Wolff, Wilhelmina Drucker, Queen Wilhelmina, Joke Kool-Smit and Queen Beatrix

Running a household in the past: the emancipation of women at home and in the workplace

The rise of the workers' movement

\section{Secondary education sector}

The struggle for the universal right to vote

The first wave of feminism and other emancipation movements

The Dolle Mina action group and the youth revolution of sixties

International comparison of the granting of rights to women (right to vote, education, right to work, etc.)

Medicine as a field for both men and women

\section{Past and Present}

Are women fully emancipated?

In the Treasure chest

Attributes of the feminist movement (badge with the female sign, etc.)

Postcards with slogans for the vote for women (published by the IIAV)
For centuries, politics had been the exclusive domain of men, just like the academic world, the Church and the armed forces. People believed that women were not the equals of men: their job was to run the household and care for children, and therefore they could not participate in public life. There had always been criticism of this "patriarchal" view of life, but real changes only took place in the twentieth century. And a second wave of feminist campaigning was needed to achieve these changes. In the early 1970s, the “dolle minas" [Dutch women's libbers] carried out a campaign for the emancipation of women. They did not want to be condemned to lives as housewives like their mothers before them. In 1980 the Equal Opportunities Act came into force.

\section{References}

Places to Go

Heesch: Poppenhuismuseum

Arnhem: Open-air Museum

Books for young people

Kaye Stearman, Feminisme (12+ info)

Background literature

Mineke Bosch, Een onwrikbaar geloof in rechtvoardigheid: Aletto Jacobs 1854-1929, Amsterdam 2005

Fia Dieteren, Els Kloek and Antoinette Visser, Naar Eva's beeld: De geschiedenis van de vrouw in de Europese cultuur, Amsterdam 1987 Judith Amsenga, "Dolle Mina (1969-1977)", in Els Kloek (ed.), Verzameld verleden: Veertig gedenkwaardige momenten en figuren uit de vaderlandse geschiedenis, (Verloren Verleden 24), Hilversum 2004

\section{Websites}

www.alettajacobs.org www.vrouwenlexicon.nl www.iiav.nl 


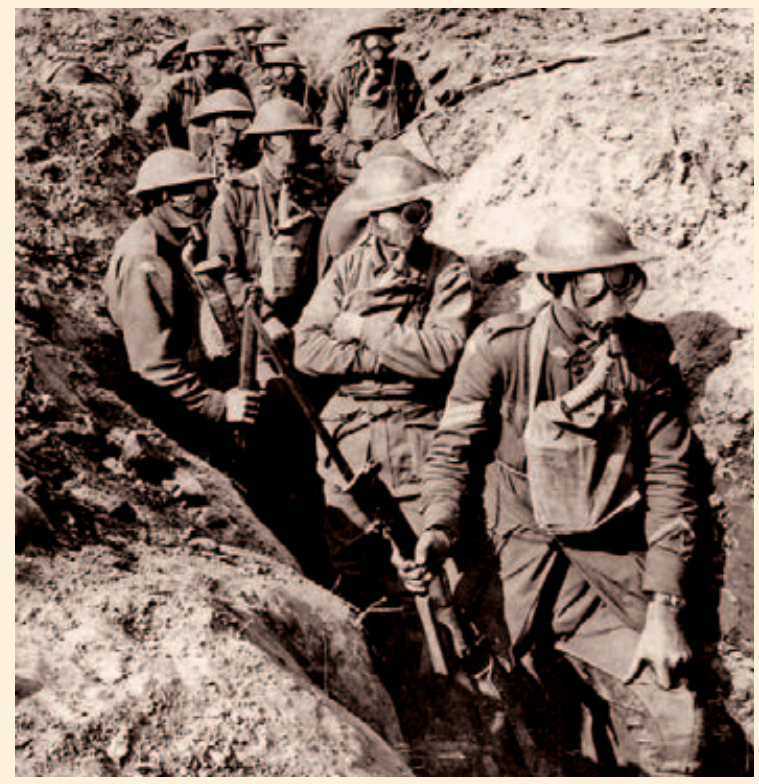

\section{$1914-1918$ World War I}

\section{War and neutrality}

From 1914 to 1918 the "Great War" raged in Europe. The war did have consequences for the Netherlands, but the country was spared its horrors. In World War I, the Central Powers (Germany, Austria and Turkey) were opposed by the Allies (France, Great Britain and Russia). However, what it actually came down to was the soldiers of the two sides facing one another along kilometres of trenches. When shooting broke out, the soldiers could do little else than take cover from the exploding shells and hope for the best. They were even more powerless when they had to attack the enemy. As soon as they went over the top of the trenches, they were mowed down by the machine guns of the other side. The use of poison gas was something new in this war. Ultimately the war cost millions of lives.
When the United States joined the Allies in 1917, the balance was tipped in the Allies' favour. In November of the following year the Central Powers surrendered.

During the war, the Netherlands had remained neutral, something that had been a principle of Dutch foreign politics for some time. The Dutch army was, however, mobilised to defend its own territory. Furthermore, the Netherlands had to deal with the peripheral effects of the war. Large numbers of Belgian refugees had to be taken in, in temporary camps, among other places. Unemployment rose due to the fall in international trade and the sinking (by torpedoes) of many merchant vessels. Food became scarce and rationing was introduced. In 1917 and 1918, despairing housewives plundered food stocks in Amsterdam and Rotterdam. 
Many European countries experienced the upheaval of revolution during or after the war. In Russia, the Tsar was forced from the throne and executed, and the German and Austro-Hungarian empires were replaced by republics. In the Netherlands, radical political changes were implement-

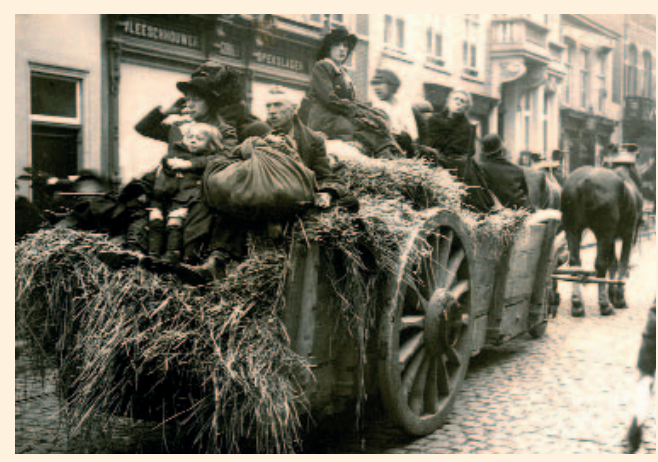

\section{Sub-topics}

Primary education sector

Trench warfare; the Battle of the Somme

The "Potato Riot"

The concept of "neutrality"

\section{Secondary education sector}

The course of the war; decisive moments

Socio-political changes in authoritarian countries

(Russia, Austria-Hungary and Germany)

Socio-political changes in democratic countries

(for example, Great Britain and the Netherlands)

The idea of "total war"

The causes of World War I and their effect on World War II

\section{Past and Present}

Are all weapons acceptable in war? Consider the weapons that were used in World War I in your answer Compare international relations in Europe on the eve of World War I with those of today

In the Treasure chest

Letters and poems written by soldiers at the front Gas mask ed during the war. In 1917 all men were granted the right to vote. After the war, in 1919, this was followed by universal suffrage for women. From 1919 onwards, the Netherlands was a fully democratic country: every adult man and woman had the right to vote in elections.

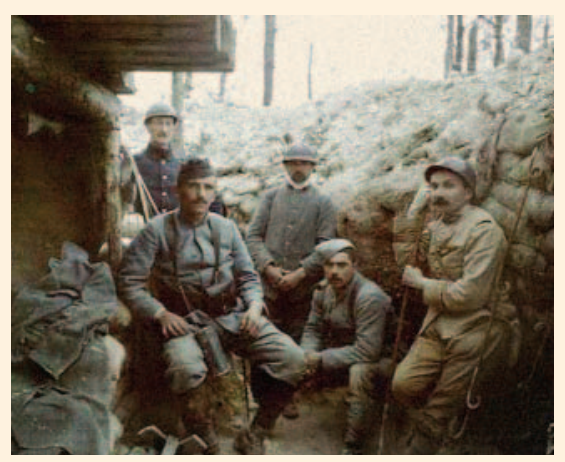

\section{References}

\section{Places to Go}

Ypres and its surroundings (south-western Flanders) are worth visiting, particularly the In Flanders Fields museum and the daily salute to the fallen, "the last post"

\section{Books for young people}

D. Adams, Oorlog in de loopgraven (12+ info) Ann Kramer, Vrouwen en de oorlog (12+ info) Stewart Ross, De Eerste Wereldoorlog (12+ info) L. Granfield, In Flanders fields (13+) Michael Morpurgo, Soldaat Peaceful (13+) Karel Verleyen, De Eerste Wereldoorlog 1914-1918: Alle grote gebeurtenissen van Serajevo tot Verdun (14+ info)

\section{Background literature}

Paul Moeyes, Buiten schot: Nederland tijdens de Eerste Wereldoorlog: 1914-1918, Amsterdam 2001

\section{Websites}

www.wereldoorlog1418.nl www.geschiedenisvoorkinderen.nl eerstewereldoorlog.startpagina.nl www.inflandersfields.be 

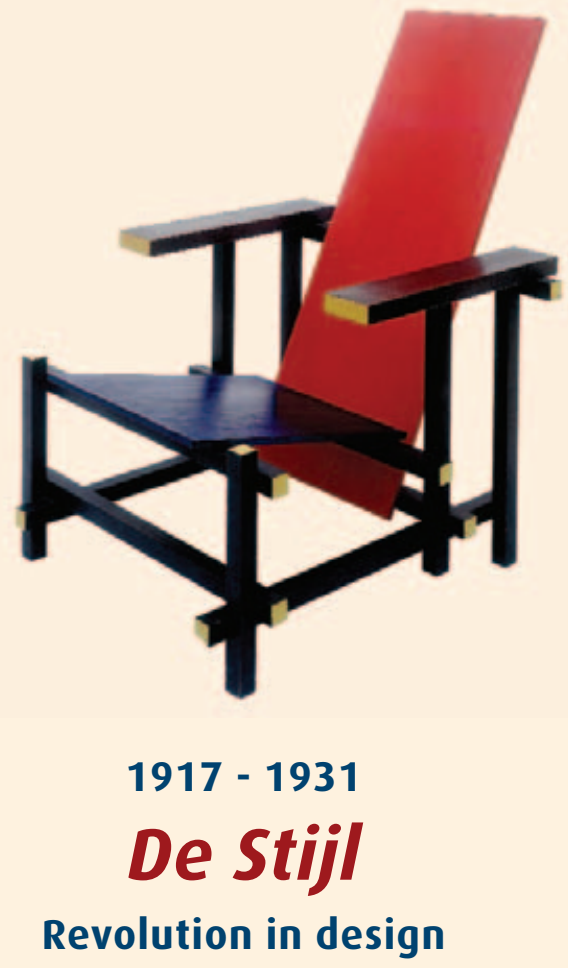

Gerrit Rietveld's famous red and blue chair of 1918 is not only red and blue: the frame is yellow and black.

The chair therefore still meets the requirements that the artists of the De Stijl (The Style) movement upheld with regard to visual arts. In their eyes, only the three primary colours (red, blue and yellow) and the three "non-colours" (black, white and grey) were acceptable. Moreover, all lines had to be straight and the angles right-angles.

Their principles of colour are still reflected, for example, in the works of Dick Bruna ("Miffy"). In fact, Dick Bruna was influenced by De Stijl but he deviated from the strict principles by immediately using the colour green and curved lines. More important than the design aspects of De Stijl was the substantive task that the artists set themselves. The artistic content of their work was not meant to reflect reality, but rather to express the harmony that they believed was the law of the universe. This harmony demanded abstract shapes - straight lines and bright colours. Their works of art therefore did not simply reflect the incidental state of mind of the artist but helped the public along the path to truth and purity.

The group and their monthly journal called "De Stijl" were established in 1917. It is easy to understand that this longing for harmony developed in the chaotic times of the World War I. The journal continued to be printed until 1931, when the artist Theo van Doesburg died. After his death the group dissolved. The artists who made up De Stijl were not a fixed group: the composition fluctuated. The architect Gerrit Rietveld and the artist Piet Mondrian, two of the movement's key members, never even met one another. 
De Stijl was very internationally-oriented and gained an international reputation. And yet the movement was firmly rooted in Dutch traditions. The art historian H.L.C. Jaffé once said that the aim of De Stijl - to achieve the abstract, beauty and purity - had its origins in the iconoclasm and the restrained, Calvinist art of seventeenth-century Dutch painters like Vermeer, Saenredam and De Hooch.

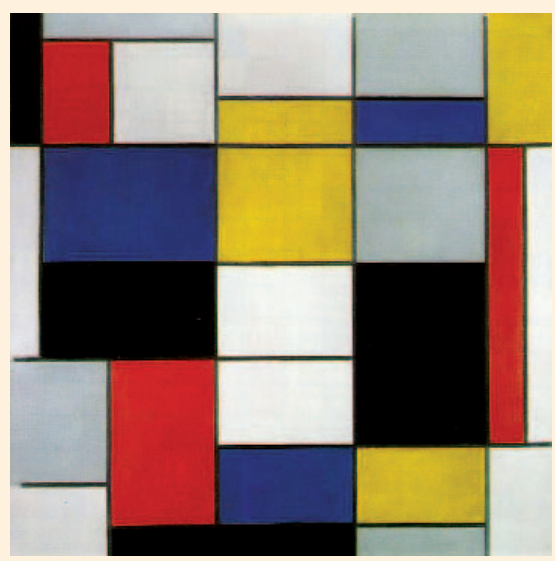

\section{Sub-topics}

Primary education sector

Gerrit Rietveld (1888-1964)

Piet Mondrian (1872-1944)

Typography and design

\section{Secondary education sector}

Modernism

Het Nieuwe Bouwen [The New Architecture]

Concrete poetry (typographic poetry, Paul van Ostaijen)

Dada

Design (the tradition of furniture design and industrial design in the Netherlands)

\section{Past and Present}

Modern design in the Netherlands

Modern architecture

How are your house and school designed?

Does the design affect the moods of those who live and work there?

\section{In the Treasure chest}

De Stijl ashtray, Mondrian oven mitt or Rietveld placemat
According to Jaffé, one can even see similarities between the art of De Stijl and the struggle of the Dutch to master nature. After all, the Dutch landscape with its precise geometric shapes, its straight lines and waterways brings to mind the paintings of Mondrian. In short, geometry and precision, the abstract and purity had been sought in the Netherlands for centuries and this is reflected in the artistic works of the De Stijl movement.

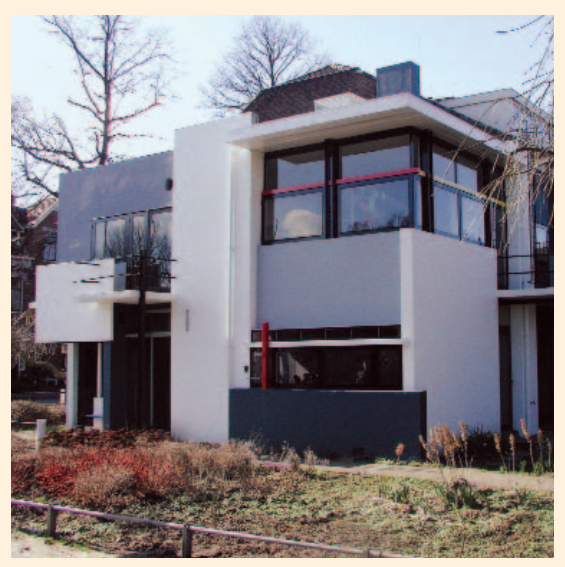

\section{References}

Places to Go

Utrecht: Schröderhuis (Gerrit Rietveld)

Rotterdam: Café De Unie (J.J.P. Oud)

The Hague: Gemeentemuseum

Utrecht: Centraal Museum

Amsterdam: Stedelijk Museum

Books for young people

Gaff, Design 1920-1940 (10+ info)

\section{Websites}

www.rietveldschroderhuis.nl www.dutchdesign.nl 


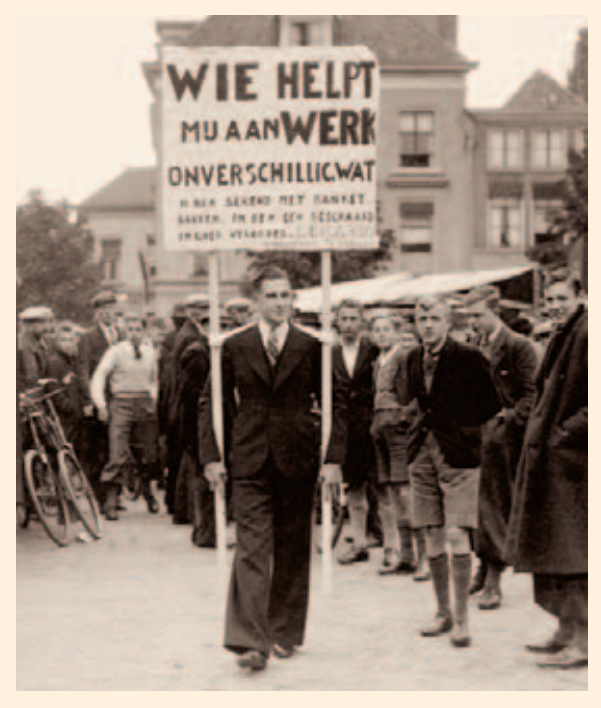

\section{9 - 1940 \\ The crisis years \\ Society in the depression}

The years from 1929 to 1940 are usual referred to as the "crisis years" or the "great depression": a long period of a falling economy and large-scale unemployment. The crisis began in October 1929 in the United States after the Wall Street Crash and soon the whole world was in the grip of the depression.

The number of unemployed in the Netherlands in 1930 totalled about 100,000 and reached its peak in 1936 with 480,000 people out of work. The numbers fell somewhat after this time but until the outbreak of the war, hundreds of thousands of people remained out of work. Up until then, unemployment rates in the Netherlands had never been this high and the situation had never lasted for so long. One out of every four Dutch citizens had been out of work for a year or longer.

The government decided to provide the unemployed with financial support.
This support could not be too high, because - according to the government that would make the unemployed lazy. The benefit paid out was just enough to pay the rent and provide a simple meal. There was no money left for entertainment, sports or clothes. To prevent the unemployed from accepting cash-in-hand work alongside their benefit, they had to have their dole card stamped at unemployment office once or twice a day. This was considered very humiliating. In addition, the unemployed could be forced to work in the relief work programme. This meant that a teacher could be forced to take a spade and dig ditches or build dykes. Large public works like the Amsterdamse Bos (Amsterdam Woods) date from this time.

The government, under Prime Minister Colijn, chose to keep its hands on the purse strings as much as possible. 
The budget had to be balanced, and for a long time Colijn refused to reconsider the value of the Dutch guilder. This policy of economising was highly criticised particularly by the socialists who believed that the government needed to implement a much stronger economic policy.

The government appeared powerless to resolve the crisis and many Dutch citizens began to have doubts about their parliamentary democracy: the system seemed to represent division and lack of decisive action. This criticism did not, however, lead to a significant shift of votes to the right or left at the elections. The large democratic parties managed to retain most of their support. The National Socialist Movement, which promoted powerful leadership, remained a small right-wing party with little support.

After World War II, new ideas arose about tackling the problem of

\section{Sub-topics}

\section{Primary education sector}

The social circumstances of the employed and unemployed in the 1930 s

The rise of national socialism in Germany Unemployment, the people and the state

\section{Secondary education sector}

The different approaches to unemployment in the Netherlands, Germany and the United States The differences between the socio-economic policy of the 1930 and that of the post-World War II period

colijn and the crisis

Keynes and the crisis

Malaise and extremism

\section{Past and Present}

Comparisons between the life of the unemployed in the 1930 s and the life of today's unemployed

Unemployment today, in the Netherlands and its neighbours

Government policy: economising or large-scale spending?

\section{In the Treasure chest}

Dole card

The free Bicycle Tax Plate with a hole signifying unemployment

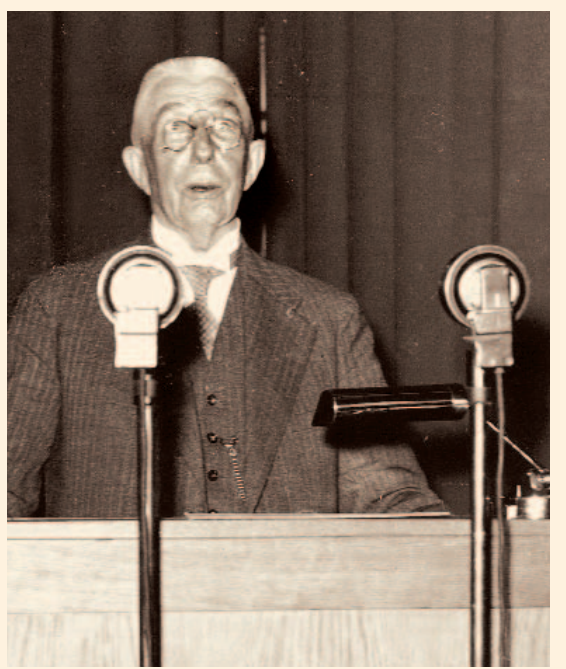

unemployment. Unemployed people were approached in a more human, less suspicious manner. In addition, the government made greater efforts to assist the unemployed in finding work.

\section{References}

\section{Places to Go}

Amsterdam: De Burcht, Vakbondsmuseum

\section{Books for young people}

Benny Lindelauf, Negen open armen $\left(12^{+}\right)$

Aline Sax, Wij, twee jongens (emigration to the US) (12+)

Miek Dorrestein, Aardappels met lowaaisaus

\section{Background literature}

Norbert-Jan Nuy, "Het Jordaanoproer (1934)", in Els Kloek (ed.), Verzameld verleden: Veertig gedenkwardige momenten en figuren uit de vaderlandse geschiedenis, (Verloren Verleden 24), Hilversum 2004

J.C.H. Blom, Crisis, bezetting en herstel: Tien studies over Nederland 1930-1950, Rotterdam 1989

\section{Websites}

www.iisg.nl (Institute of Social History) www.schooltv.nl/vroegerenzo [the 1930s] geschiedenis.vpro.nl/programmas [the 1930s] 


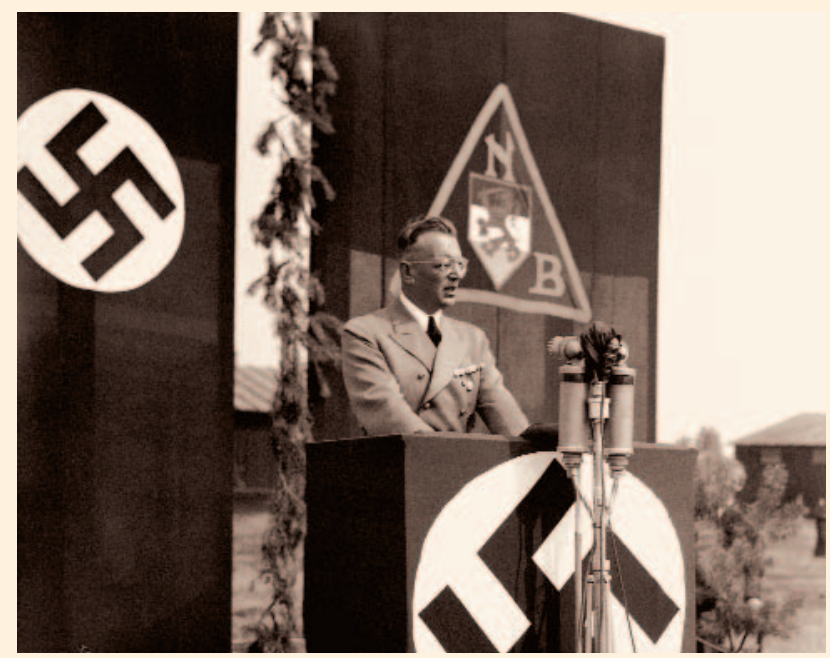

$1940-1945$

\section{World War II}

\section{occupation and liberation}

In 1933 Adolf Hitler came to power in Germany. He was the leader of the National Socialist German Workers Party, the NSDAP, known in English as the Nazi Party which promoted anti-Semitism. The party profited from the discontent felt by many Germans about the humiliating way in which Germany had been treated after World War I. Hitler intended to make Germany the most powerful country in Europe. He first directed attacks on Austria, Czechoslovakia and Poland. Subsequently he planned to neutralise Germany's most stringent opponent in Western Europe: France. Both the Netherlands and Belgium were to be occupied in Hitler's invasion of France.

On the morning of Friday, 10 May 1940, many Dutch citizens were awoken by the droning of aircraft, exploding bombs and the rattling of tanks. German soldiers had crossed the border. The war had started. The Dutch army was far too weak to stand up to the force of the German assault. Once the Germans had bombed the centre of Rotterdam into the ground and were threatening to treat other cities in the same way, the Dutch military command decided to surrender. The government and the queen had already fled to England.

Initially, the occupation did not seem too bad, but it quickly became clear what occupation really meant. Dutch men were forced to go and work in German factories. People were also taken away to prisons and concentration camps without any form of due process. The Jews in particular were persecuted. The occupying Germans transported over 100,000 Jewish men, women and children in freight trains from the Netherlands to concentration camps where most of them were put to death.

The Germans were assisted by members of the Dutch National Socialist Movement (NSB), who had a similar ideology, and by hangers-on and profiteers. On the other 
side was the resistance movement, which gained a lot of support towards the end of the war in particular. The great majority of the Dutch population was anti-German but passive.

In the autumn of 1944, the south of the country was liberated by allied troops. The area above the great rivers, however (particularly the towns in the western provinces), had to endure the "winter of

\section{Sub-topics}

\section{Primary education sector}

The German invasion of the Netherlands and the bombing of Rotterdam

Stories of the Resistance: the attack in Leeuwarden, Putten, Hannie Schaft, Engelandvaarders [the England-bound]

The NSB [National Socialist Movement]

The Hongerwinter [winter of starvation]

The Battle of Arnhem, D-day and liberation in May 1945

\section{Secondary education sector}

Types of collaboration, acceptance and resistance of the Dutch people

The Dutch policy of neutrality in the 1930 s in the face of the German threat

The bombing of Rotterdam compared to other bombing campaigns (Warsaw, Coventry, Dresden)

Collaboration, acceptance and resistance of the Dutch people

World War II in Dutch literature (poetry and prose)

\section{Past and Present}

Why is World War II still commemorated on 4 and 5 May each year?

Monuments commemorating World War II (in almost every Dutch town)

In the Treasure chest

Ration card

Identity card

DVD Kind in de oorlog, released by the Netherlands Institute for War Documentation starvation" before being liberated in their turn. An extreme food shortage weakened the population and tens of thousands died. In May 1945 the German commander signed the surrender and the whole of the Netherlands was liberated. At that time, the Dutch East Indies was still in the hands of the Japanese. Japan surrendered on 15 August 1945.

\section{References}

\section{Places to Go}

National War and Resistance Museum

Amsterdam Resistance Museum

Military cemeteries

\section{Books for young people}

Eric Heuvel, De ontdekking (Amsterdam 2003); cartoon that provides insight into many of the dilemmas the Dutch population was faced with during the war

Zwarte confetti, foto's, verhalen, gedichten en tekeningen over de oorlog (10+)

Paul Biegel, De karabijn (8+)

André Boesberg, Zwarte stod (Russia, 1942) (12+)

Herman van Campenhout, Pikadon (Hiroshima) $(12+)$

Mirjam Elias, Het verlaten hotel

Reg Grant, De Tweede Wereldoorlog in Europa (12+ info)

Dennis Hamley, De Tweede Wereldoolog (12+ info)

Evert Hartman, Oorlog zonder vrienden (12+)

Els Pelgrom, Kinderen van het Achtste Woud (12+)

Aline Sax, Mist over het strand (12+)

Jan Terlouw, Oorlogswinter (12+)

Anke de Vries, Belledonne kamer 16 (France) (12+)

Anna and Wout Woltz, Post uit de oorlog, (Amsterdam) $(12+)$

\section{Background literature}

L. de Jong, De bezetting na vijftig joar. (3 volumes), The Hague 1990

Chris van der Heijden, Grijs verleden: Nederland en de Tweede Wereldoorlog, Amsterdam/Antwerp 2001

David Barnouw, De hongerwinter. (Verloren Verleden 6), Hilversum 1999

\section{Websites}

www.spion.nl, a cooperation project running since 1999 between the National 4 \& 5 May Committee and various war and resistance museums, memorial centres and producers of educational material in the Netherlands 


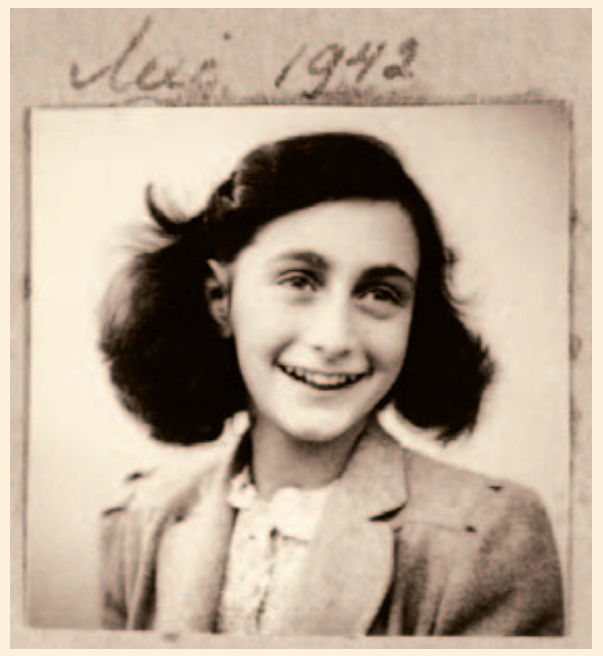

\section{9 - 1945 \\ Anne Frank \\ The persecution of the Jews}

Anne Frank was born into a Jewish family in the German city of Frankfurt am Main in 1929. The family fled to Amsterdam in the summer of 1933. That was the year in which Hitler came to power and began his policy of driving the Jews out of the country.

The Frank family found a house in the Rivierenbuurt in Amsterdam. Anne went to school there and learned Dutch. After the occupation in May 1940, the German authorities implemented measures in the Netherlands aimed at isolating the Jews from the rest of Dutch society. It was a dramatic moment for Anne when she had to say goodbye to her fellow pupils and teacher, because she had been transferred to a Jewish school. Jews were forced to wear a star of David so that they were easily recognisable in public. Signs were hung in cinemas, cafés and theatres stating: "Entry Forbidden to Jews". From July 1942, the German occupation forces implemented a large-scale operation in the Netherlands to transport Jews to Eastern Europe. Jewish families were notified to pack their bags for work in the East. They were collected from their homes, put on trains to the transit camp at Westerbork in the province of Drenthe and from there they were taken to death camps in Eastern Europe. Over 100,000 Jewish men, women and children from the Netherlands died in concentration camps. In total, some six million European Jews were killed in the holocaust.

In 1942, together with four other people, the Frank family went into hiding in a house behind Anne's father's company on the Prinsengracht in Amsterdam. It was here that Anne began to keep the diary which made her famous after the war. She wrote about her experiences as a young, ambitious girl living in a stifling, small room. Later - when she was free again - she wanted to become a 
writer. The family managed to stay hidden from the Germans for two years but were then betrayed and captured. Anne died in the German concentration camp Bergen-Belsen in 1945, aged only fifteen. Her sister also died there. Her mother died in Auschwitz. Her father, Otto Frank survived the camp and returned from Poland.

After the war, Miep Gies, a woman who had helped the family when they were in hiding, gave Otto Frank a bundle of exercise books. These were the diaries his daughter Anne had written. Otto Frank took the diaries to several publishers and in 1947 they were published under the title Het Achterhuis. (The English title is: Anne Frank: The Diary of a Young Girl.) In 1955, an

\section{Sub-topics}

\section{Primary education sector}

What does the word "Jewish" mean? (religious background)

Nazism and the persecution of the Jews in Germany The resistance and aid to people in hiding Nazi persecution of other minorities (gypsies, homosexuals)

\section{Secondary education sector}

Discrimination against the Jews over the centuries Compliance of the Dutch in the persecution of the Jews Comparison of the number of Jewish victims in the Netherlands with the numbers in other countries (e.g. France and Belgium)

Remembering the holocaust (for example, in films) The state of Israel and the problems in the Middle East

\section{Past and Present}

What kinds of anti-Semitism still exist today?

What kinds of discrimination are minorities subjected to today?

Anne Frank, world famous (find out more via Google)

In the Treasure Chest

Star of David

Identity card with a 'J' printed on it
American stage adaptation of the diaries made the book world famous - just in time to save the actual Achterhuis that had been recommended for demolition.

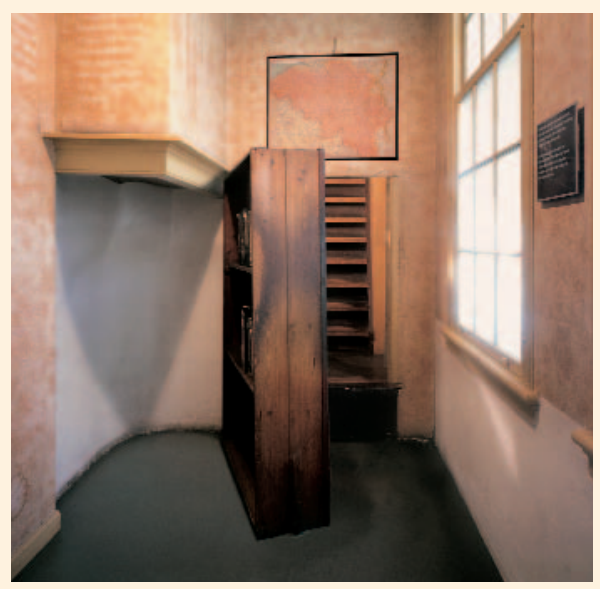

\section{References}

\section{Places to Go}

Amsterdam: Anne Frank House Amsterdam: Jewish Historical Museum Westerbork Camp Memorial Centre Vught Camp National Monument

\section{Books for young people}

Ceseli Josephus Jitta, De diamant van opa (8+)

Ruth van der Zee, Erika's verhaal (8+)

Ida Vos, Wie niet weg is, wordt gezien (9+)

Eric Heuvel, De ontdekking (10+)

Mirjam Elias, Het verlaten hotel (Amsterdam) (12+)

Peter van Gestel, Winterijs (12+)

Willy Spillebeen, Serge/Samuël (12+)

John Boyne, De jongen in de gestreepte pyjamo

$$
\text { (Auschwitz) }\left(14^{+}\right)
$$

Anne Frank, Het Achterhuis (Amsterdam) $\left(14^{+}\right)$

Clive A. Lawton, Het verhaal van de Holocaust (12+ info)

\section{Background literature}

Bob Moore, Slachtoffers en overlevenden: De nazi-vervolging van de joden in Nederland, Amsterdam 1998.

Many films and documentaries are suitable for inclusion in this window.

\section{Websites}

www.spion.nl

www.annefrank.org 


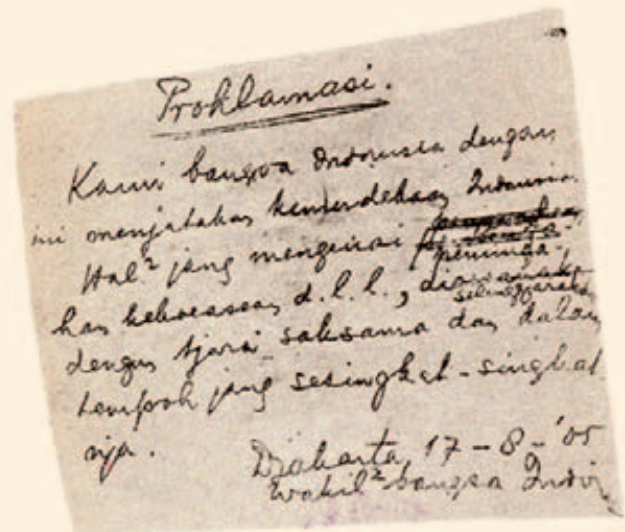

\section{5 - 1949 \\ Indonesia}

\section{A colony fights for freedom}

Proklamasi. Kami bangsa Indonesia dengan ini menjatakan kemerdekaan Indonesia...

We, the people of Indonesia, hereby declare the independence of Indonesia...

On 17 August 1945, in a brief ceremony on the streets of Jakarta, Sukarno made a short statement proclaiming to the world that colonial rule of the Dutch East Indies had ended. Two days earlier, Japan had surrendered after the dropping of atomic bombs on the Japanese cities of Hiroshima and Nagasaki. With Japan's surrender, World War II in Asia was brought to an end.

A widespread independence movement had existed in the Dutch East Indies before World War II. Nationalist leaders like Sukarno, Mohammad Hatta and Sutan Sjahrir wanted their country to be free of the Netherlands, others simply wanted more autonomy. The Dutch administration, however, kept a tight hand on the reins.

And then came the Japanese invasion in 1942. On 27 February, the allied forces were defeated in the Java Sea Battle and their surrender followed on 8 March. The allied troops became prisoners of war, most Dutch citizens were interned in civilian camps, and many men were taken into forced labour. The Japanese dismantled the administration system of the Dutch East Indies and in reality this signalled the end of the existence of the Dutch East Indies.

After 1945, the Netherlands tried to restore its colonial administration through negotiations and with force, in two police actions. However, on 27 December 1949, under a great deal of international pressure, it accepted Indonesian independence. Dutch New Guinea was only relinquished in 1962, and finally, after a transition period under UN supervision and a plebiscite held among the Papuans, the territory was ceded to Indonesia. This meant that from 1969, the national borders of modern-day Indonesia were the same as those of the former Dutch East Indies.

Fighting was heavy during the struggle for independence. By the 1960s, a total of 
over 300,000 Dutch people, Indo-Europeans, Papuans and Indonesians had left the country. Most of these travelled to the Netherlands. They included 12,500 Moluccan soldiers of the former Royal Netherlands East Indies Army (KNIL) and their families. In 1951, they arrived in the Netherlands where their military service was terminated.

This decolonisation is not yet a thing of the past. In 2005, the Dutch Minister of Foreign Affairs participated in the

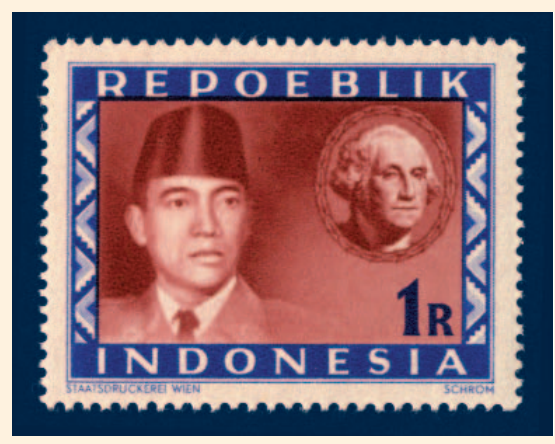

\section{Sub-topics}

\section{Primary education sector}

A map of Indonesia (including New Guinea)

Sukarno, the struggle for independence and

police actions

Indo-Europeans (from Indonesia and the Moluccas)

\section{Secondary education sector}

The legacy of the Dutch in Indonesia

The war in the Pacific

The police actions and the transfer of sovereignty

The history of the decolonisation of South Asia and South-East Asia: India, Indonesia, Vietnam

Settling in the Netherlands: the history of Indo-Europeans (from the Moluccas and Indonesia)

\section{Past and Present}

Relations between the Netherlands and Indonesia since independence

In the Treasure Chest

Picture of the coat of arms of Indonesia (with an explanation) Batik celebrations surrounding the sixtieth anniversary of Indonesian independence. In this way, the Netherlands accepted that Indonesia had gained independence not in 1949, but on 17 August 1945. Minister Bot expressed regret that the Netherlands at that time "had stood on the wrong side of history, as it were" and had caused a great deal of suffering in so doing. This was an important, sometimes confrontational speech for everyone involved - in Indonesia and the Netherlands alike.

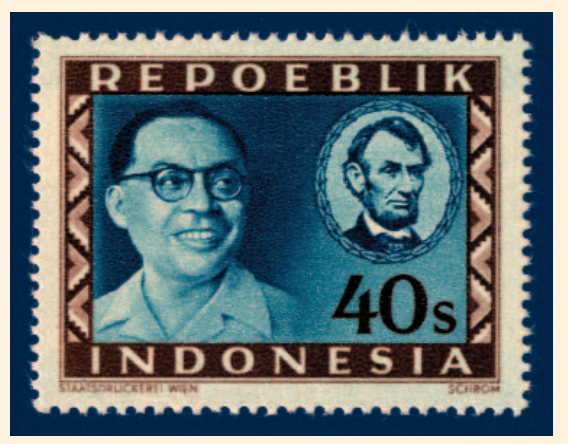

\section{References}

\section{Places to Go}

Monuments in numerous towns (the Indonesian monument in The Hague, etc.)

Utrecht: Moluccan Historical Museum

Arnhem: Open-air Museum, Bronbeek

Amsterdam: Tropical Museum, Resistance Museum

Indonesian restaurants

\section{Books for young people}

Marion Bloem, Matabia, of een lange donkere nacht $\left(9^{+}\right)$ Wieteke van Dort, Kind in Surabaja, Indische herinneringen $\left(9^{+}\right)$

Vivian den Hollander, Alleen Beer mocht mee $\left(9^{+}\right)$

Robin Raven, De vloek van Pak (9+)

Hella Haasse, Oeroeg $\left(14^{+}\right)$

Pramoedya Ananta Toer, Guerrilla fomilie $\left(14^{+}\right)$

\section{Background literature}

Frans Glissenaar, Indië verloren, rampspoed geboren. (Verloren Verleden 19), Hilversum 2003

\section{Websites}

www.nationaalarchief.nl [...] Royal Netherlands East Indies Army (KNIL) 


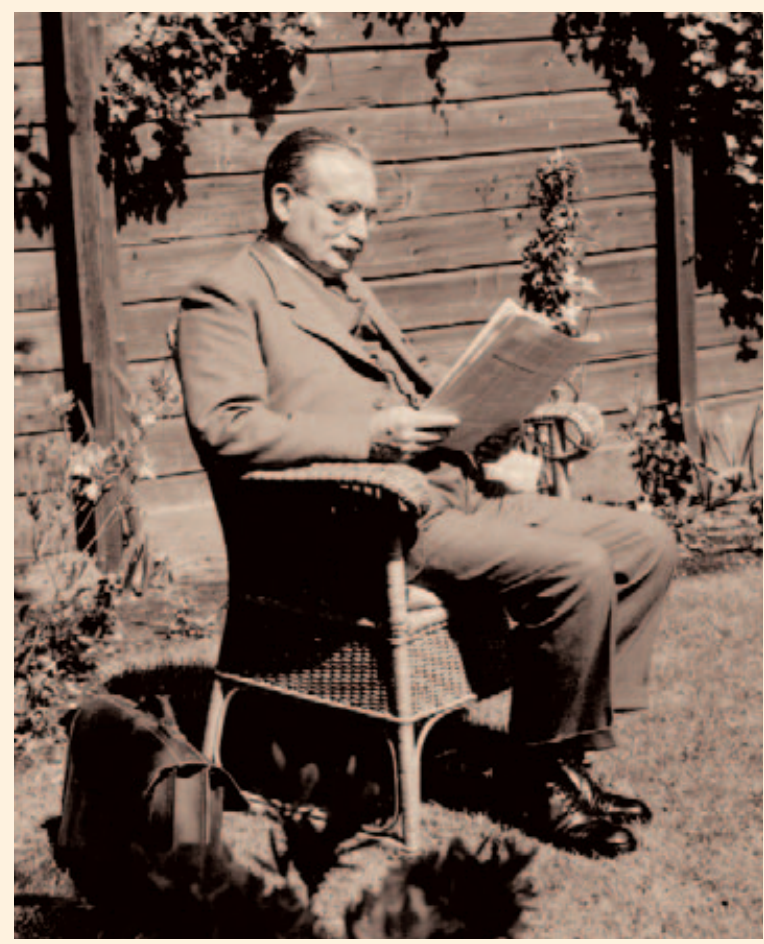

\section{$1886-1988$ \\ Willem Drees}

The welfare state

Willem Drees was one of the most popular Prime Ministers in Dutch history. He was known as "Vadertje" (Father Drees) a nickname that shows the socialist Prime Minister was a father figure not only for his own party but for the entire population of the Netherlands. His enormous popularity was largely due to the emergency law on state old-age pensions he implemented in 1947.

At an early age, Drees joined the Social Democratic Workers' party (SDAP), the predecessor of the Dutch Labour Party $(\operatorname{PvdA})$. He experienced the crisis years of the 1930 as an alderman in The Hague and tried to alleviate the effects for municipal employees. After the war, Drees entered the cabinet as Minister of Social Affairs. From 1948 to 1958 he was Prime Minister of the Christian Democrat and Social Democrat coalition (rooms-rode coalitie).

Stories about Willem Drees always mention his thriftiness and simplicity. The most important politician in the Netherlands went to work every morning either on foot or by bicycle - he did not need a chauffeur-driven car. At the time, most politicians enjoyed cigars and drinking, but Drees refrained. And when an American diplomat visited Drees at home to discuss American financial support for 
the Dutch economy, Mrs Drees apparently served him a cup of tea and a biscuit. The American supposedly said that a country with such a thrifty Prime Minister was undoubtedly greatly in need of assistance through the Marshall Plan.

Drees was closely tied to the years in which the Netherlands was recovering from World War II. The economy had to be kick-started and everyone had to lend a hand. The emphasis was placed on cooperation rather than conflict. Employees agreed to low wages to achieve a competitive position for the Netherlands in respect of other countries. This meant that most people had to postpone buying a car or a television set. In politics, cooperation was the top priority, even though pillarisation was ingrained in Dutch society during those

\section{Sub-topics}

\section{Primary education sector}

The reconstruction of the Netherlands after World War II; economic boom at the end of the 1950s

The building of the welfare state (what did this actually mean for large groups of people?)

Drees and later Dutch Prime Ministers

\section{Secondary education sector}

The 1950 s as the start of de-pillarisation

Economic growth and the standard of living in the Netherlands in the 1950 s and 1960 s compared to other European countries

The influence of American culture in the Netherlands (from the Marshall Plan to McDonald's)

\section{Past and Present}

Where does the income of today's grandparents come from?

What does "ageing" mean and what problems will an ageing population create in the future?

The politics and legacy of Drees

In the Treasure chest

A bank statement with a state old-age pension payment years and most of the Dutch lived their lives within their own small social circle. Catholic boys joined a Catholic football club, socialists joined a socialist hiking association.

The Drees cabinets were broad-based, with Catholics and socialists having the most sway. Together, they built the Dutch welfare state. The best-known measure from that time is the state Old-age Pension Act (AOW) of 1956, which Drees initiated in 1947 with his emergency law for the elderly. Every elderly person over the age of 65 received a pension from the state. Pensioners at the time talked about "drawing money from Drees" as if he were paying them out of his own pocket. When Willem Drees died in 1988, he was 101 years old, so he certainly had time to enjoy his old-age pension.

\section{References}

\section{Places to Go}

Arnhem: Open-air museum (interior furnishings in the twentieth century)

Once it reopens, the Rijksmuseum in Amsterdam will display Drees's study

\section{Background literature}

Hendrik Henrichs, "Vadertje Drees (1886-1988)", in Els Kloek (ed.), Verzameld verleden: Veertig gedenkwaardige momenten en figuren uit de vaderlandse geschiedenis. (Verloren Verleden 24), Hilversum 2004

Henk te Velde, Stijlen van leiderschap: Persoon en politiek van Thorbecke tot Den Uyl, Amsterdam 2002 (pp. 155-190, "Gewone Nederlanders, De tijd van Drees")

\section{Websites}

www.iisg.nl/bwsa/bios/drees.html http://www.geschiedenis.nl/index [Willem Drees] www.drees.nl www.anno.nl/anno/anno/io03194.html geschiedenis.vpro.nl/dossiers 


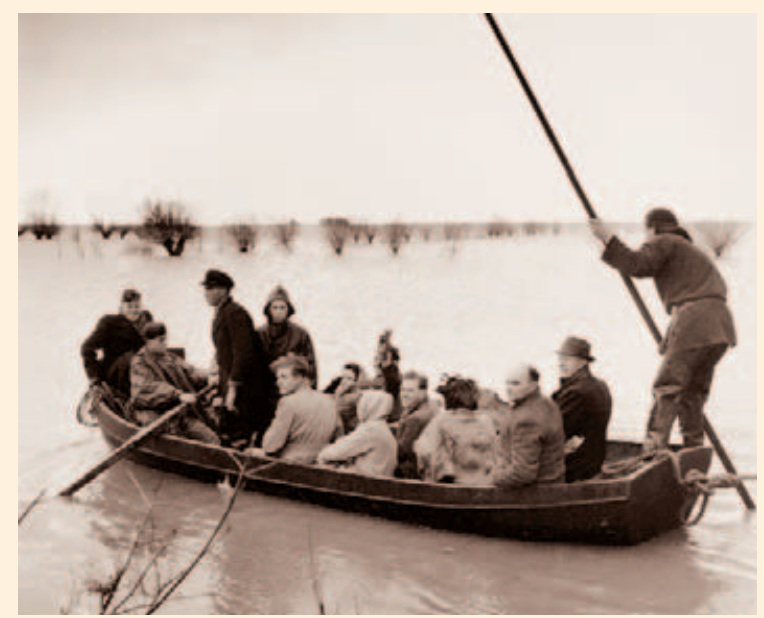

\section{February 1953 The great flood The danger of water}

Late in the night of 31 January 1953, the dykes of the province of Zeeland gave way during an enormous storm: 1,835 people lost their lives, 72,000 people lost their homes and 200,000 hectares of land were flooded. A national disaster. Across the whole of the Netherlands, money and clothing was collected, evacuees were warmly welcomed and aid arrived from abroad.

The disaster could have been much worse. If the dykes of the province of South Holland had not held, another 30,000 might have drowned and a further one million would have been made homeless. Because, behind these dykes, close to the Dutch IJssel, lies the lowest part of the Netherlands. The waters would have reached levels of over seven metres in most places if these dykes had burst.

To prevent such a disaster reoccurring, soon after the flood, work was begun on the Delta works storm surge barrier.
Plans had been made earlier to strengthen coastal flood barriers, but due to the war and post-war reconstruction they had not been implemented yet. All the gaps between the islands were closed by dams. The sea and river dykes were strengthened and a storm surge barrier was built in the Dutch IJssel.

As they went along, the engineers realised that not all the arms of the river should be sealed off because this would cause the unique natural environment to disappear. For this reason, a storm surge barrier was built in the Oosterschelde with openings that are only closed in the event of an emergency. The Westerschelde could not be sealed off from the sea, because it provides access to the ports of Antwerp and Ghent. Consequently, the sea dykes were simply reinforced here. Thanks to this enormous project, the south-western Netherlands is much more secure against flooding than ever before. At the same time, new bridges and dams 
have improved the accessibility of the islands of Zeeland, which has fostered the development of industry and tourism in the province.

The great flood of 1953 clearly illustrated how vulnerable large areas of the Netherlands were to flooding. It is now known that the danger is not only from the sea, but from the great rivers as well. Climate change is causing rainfall in Europe to become unpredictable and this affects the water levels of the great rivers. In 1993 and 1995, the situation in the

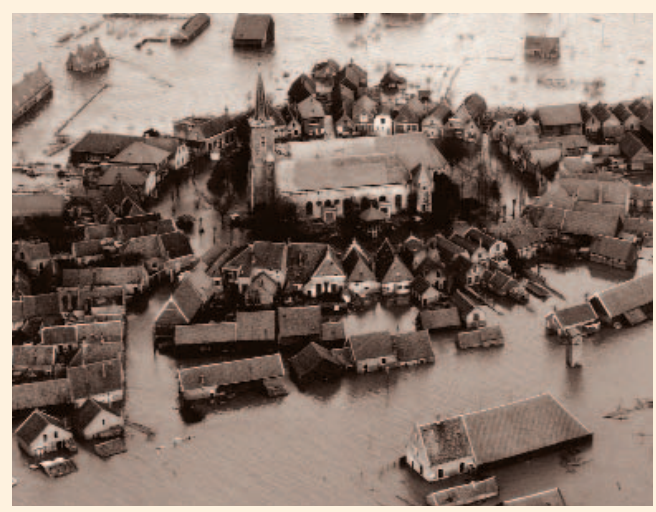

\section{Sub-topics}

\section{Primary education sector}

The Netherlands, land of water

The St. Elizabeth Flood (1421)

The draining of the IJsselmeer

\section{Secondary education sector}

The geography of the south-western Netherlands Spatial planning and water management in the Netherlands (NAP - Amsterdam Ordnance Datum) The consequences of better links with Zeeland for the inhabitants of the area

Water boards

\section{Past and Present}

Should the environment have a higher priority than security and economic issues?

Dutch engineers in New Orleans after Hurricane Katrina

In the Treasure chest

Model of a lift-lock

Photo album of the great flood
Netherlands was critical: some of the great rivers were on the point of flooding. This led to the implementation of a large number of projects to strengthen the dykes. However, experts believe that just raising the dykes is not the solution. They think that the rivers should be given more room, that building on river-forelands should be stopped and that areas should be designated for the temporary storage of excess water. This philosophy translates into learning to live with water and not in conflict with it.

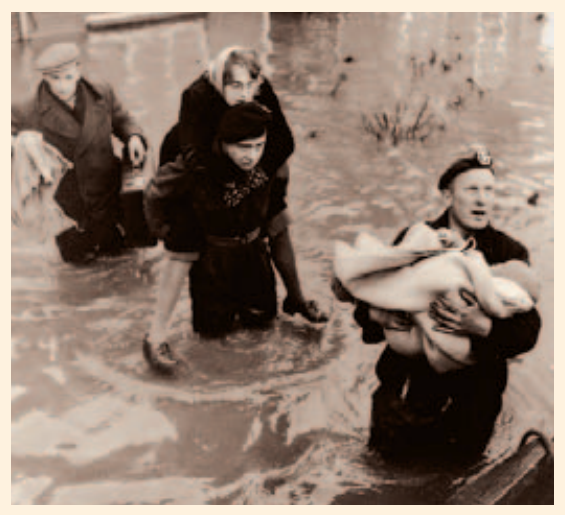

\section{References}

Places to Go

Vrouwenpolder: WaterLand Neeltje Jans

Ouwerkerk: Watersnoodmuseum

Trip across the Westfriese Zeedijk

Cruquius: Steam pumping station

\section{Books for young people}

Bert Jansen, Rikkert en de ramp

Hans Petermeijer, De nacht dat het water kwam Jan Terlouw, Oosterschelde, windkracht $10(12+)$

\section{Background literature}

Kees Slager, De ramp: Een reconstructie van de watersnood van 1953, Amsterdam 2003

\section{Websites}

www.watersnood-1953.startkabel.nl www.neeltjejans.nl

www.deltawerken.com 


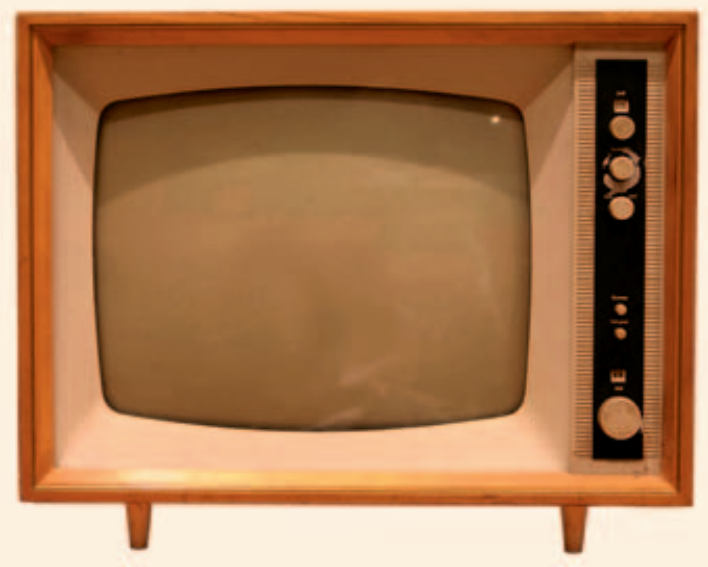

\section{8 - the present Television The rise of mass media}

In the 1950s, the Philips company was one of the driving forces behind the introduction of television in the Netherlands. In advertising campaigns, the Eindhovenbased company praised the new medium as a phenomenon that did not pose a threat to the traditional family but would rather strengthen it. The advertisements often showed a happy and harmonious family watching the screen that was bringing the world into their living room.

In order to capture a segment of the European market, Philips first had to sell a sufficient number of sets in its own country. To this end, in 1948 the company began the experiment of broadcasting programs that could be received in Eindhoven and the surrounding area. In 1951, radio broadcasting corporations in Bussum took up the television experiment. The densely-populated western Netherlands was now receiving broadcasts with the full support of Philips.

In those days of thriftiness and diligence, Prime Minister Drees attempted to limit private spending, but by the end of the fifties this innovation could no longer be resisted. By about 1961, one million television sets were in use in the Netherlands and around twenty hours a week of programs were being broadcast. The news, dramas, entertainment and sporting events were popular viewing. Around 1970, virtually every household in the country had a black and white set and some had even moved on to colour.

The arrival of the television caused great changes in the living room. The focus was no longer on the dining table because everyone had to have a good view of the TV from the sofa or an easy chair, preferably with a side table nearby with snacks and a drink. The use of leisure time was also affected. By around 1970, the average Dutch person watched about one and a half hours of television a day and spent much less time on activities like playing cards and board games. Critics believed that this viewing behaviour would lead to passivity and 
encourage slavish consumerism.

Supporters of the new medium, however, pointed out the fun that families had while watching together and the informative function served by television. Television also played an important role in shaping opinions on social topics. Due to the limited viewing choice (until 1964 there was only one channel, and only two thereafter), many people used to watch the same programmes. When they arrived at work the next morning, they had something to discuss. Programs about controversial issues like sex, emancipation, youth culture, religion and the royal family invited a lot of discussion. With the introduction of cable and satellite television, the range of programs on offer became much broader and more international. Today, most people spend more hours watching television than people in 1970 did, but watching television as a family activity is less common, due in part to the fact that a great many

\section{Sub-topics}

\section{Primary education sector}

Rising prosperity in the 1950 s and 1960 s

Philips: from small local factory to multinational

\section{Secondary education sector}

Controversial television (Open het dorp [fund-raising telethon], Beeldreligie [parody of television addiction using the language of religion], the moon landing)

Television and globalisation

Television and creativity

The role of large international companies in the Dutch economy

Philips and the stock exchange

\section{Past and Present}

How do we use television today?

Are there disadvantages to watching television?

In the Treasure chest

The DVD 50 jaar NOS journaal: hoogte- en dieptepunten uit het nieuws (Veen Magazines 2006)

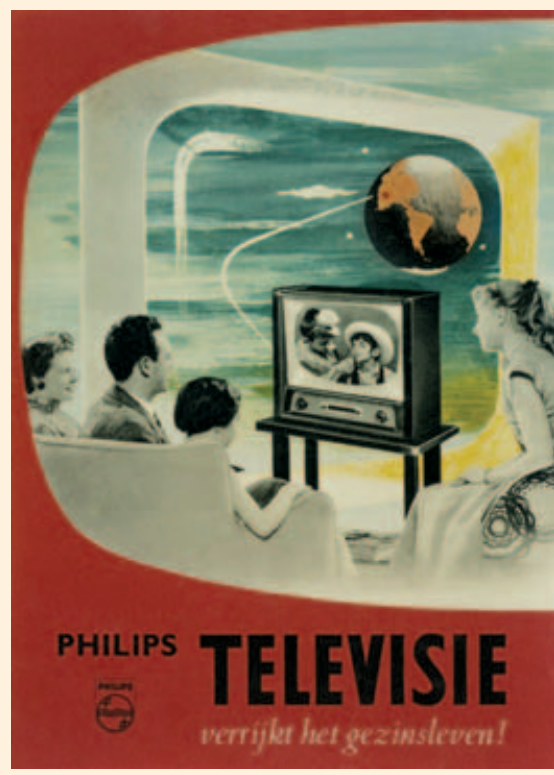

children have their own television sets. This individualisation has continued with the advent of the internet, that offers an even wider window through which to view the world .

\section{References}

\section{Places to Go}

From December 2006, the former Broadcasting Museum will be housed in the National Audiovisual Archives and the Images and Sound Experience (www.beeldengeluid.nl)

\section{Books for young people}

Alison Cooper, Machtige media? (series: Standpunten) (12+ info)

Brecht van Hulten and Jean Paul Schutten, Het NOS Jeugdjournaal (series: Notendop junior) (10+ info) Wordworth, Film en televisie (12+ info)

\section{Background literature}

Jan Bank, "Televisie verenigt en verdeelt Nederland" in H. Wijfjes (ed.), Omroep in Nederland: 75 jaor medium en maatschappij 1919-1994, Zwolle 1994

\section{Websites}

www.beeldengeluid.nl

www.teleblik.nl

geschiedenis.vpro.nl/dossiers

www.philips.nl 


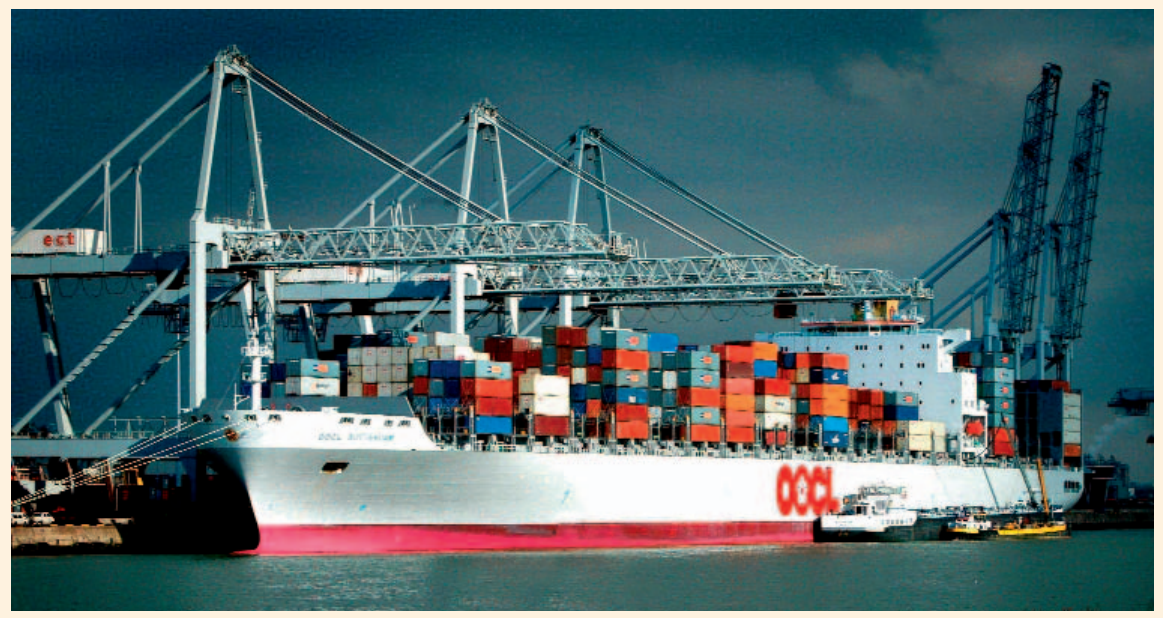

\section{circa 1880 - the present The port of Rotterdam}

\section{Gateway to the world}

If there is one place that has made the Netherlands such an important trading nation in modern times, it is Rotterdam. The port lies at the delta of major European rivers, is accessible for sea-going ships and currently has access to a market of one hundred million people just a day's drive away. It is the natural location for Europe's major port. The rebuilding of the port was therefore a top priority during the post-war reconstruction of the Netherlands. The port was severely damaged in World War II - almost half of it was destroyed. Due in part to the re-emergence of Germany and successful European cooperation, trade with the German market was restored. Growth was so swift that by the 1950s expansion of the port was needed: the Eemshaven and Botlek were developed.

Rotterdam had only become the major port of the Netherlands in the nineteenth century. Although the city had existed for a long time, it had not been considered a top priority port. In around 1250 , a dam was built in the estuary of the small Rotte River to prevent inflowing seawater from making the river-water too salty. At the dam, goods were loaded by hand from riverboats onto coasters - this was the beginning of the port of Rotterdam. In the sixteenth century, Rotterdam developed into an important fishing port and later the city had some share of the colonial expeditions. However, Rotterdam never became the centre of colonial trade: the port at that time was too difficult to reach from the sea and moreover, the major financiers and entrepreneurs had their offices in Amsterdam.

In the second half of the nineteenth century, the port changed dramatically. Mining and industry began to flourish in the German Ruhrgebiet. Furthermore, Rotterdam became much more easy to reach from the sea. Under the direction of hydraulic engineer Pieter Caland, the dunes at the Hook of Holland were cut 
through and a new link was dug to the port: the Nieuwe Waterweg (New Waterway). In the port itself, new harbour basins were dug. Steam cranes and other machinery facilitated loading and unloading, and freight trains transported the products quickly.

The port of Rotterdam has grown continuously over the past forty years, for example, with the development of the Europoort and the Maasvlakte. It is important to the Netherlands government to keep the port of Rotterdam competitive.
Just like Schiphol Airport, Rotterdam is a main port, a hub for Dutch international trade relations. Today, globalisation means that goods are transported intensively from one end of the globe to the other. Competition is increasing - even between ports. For this reason the state is paying extra attention to the design and accessibility of the port of Rotterdam. The Betuwelijn, a new freight railway line between Rotterdam and Germany, is one of the projects that will lay the foundations for the future of the port.

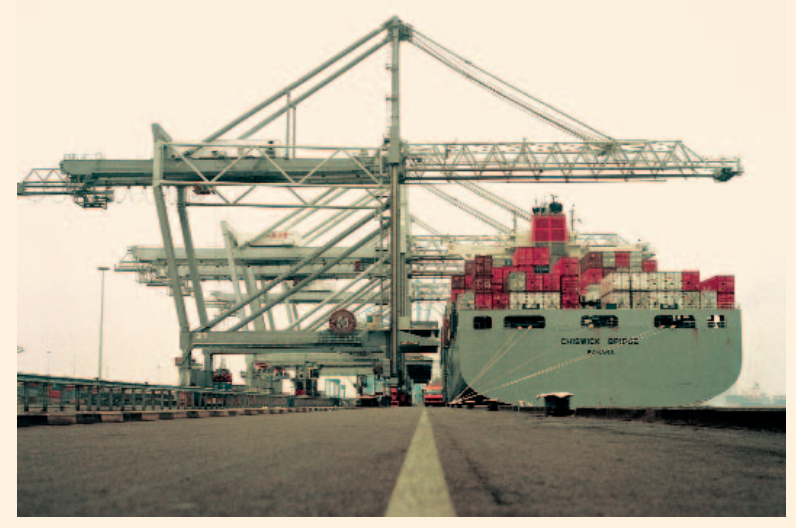

\section{Sub-topics}

\section{Primary education sector}

Working at ports: from toting sacks to operating computers

Container transport

The other main port of the Netherlands: Schiphol Airport

\section{Secondary education sector}

Spatial policy in the Netherlands

Main ports of the world

The Netherlands' trade relations

Petroleum and the port of Rotterdam

Amsterdam-Rotterdam today

\section{Past and Present}

How the port of Rotterdam is shifting towards the sea What happened to the old city ports of Rotterdam? Competitor ports: Rotterdam, Antwerp, Shanghai

\section{In the Treasure chest}

Recent map of the port of Rotterdam Model of a container

\section{References}

Places to Go

Rotterdam: Havenmuseum

Educational tours of the port for school children

Books for young people

Joris Lutz, Fred in de haven (including a CD-ROM) $\left(4^{+}\right)$

\section{Background literature}

Paul van de Laar, Stad van formaat: Geschiedenis van Rotterdam in de negentiende en twintigste eeuw, Zwolle 2000

\section{Websites}

www.gavehaven.nl

www.portofrotterdam.com

(includes a large educational section)

www.buitenmuseum.nl/publieksservice 


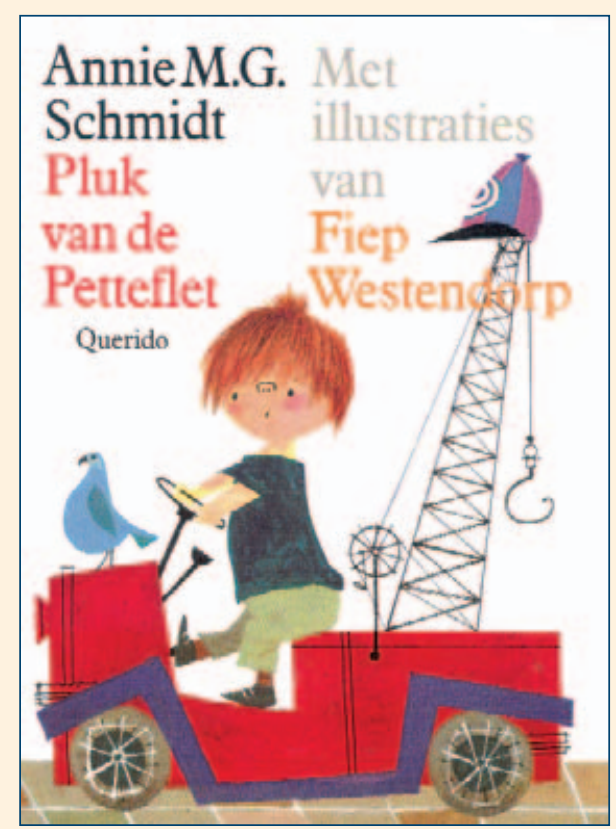

1911 - 1995

\section{Annie M.G. Schmidt}

\section{Going against the grain of a bourgeois country}

"Never do what your mother tells you to do, then everything will be alright." These words are typical of the Dutch writer Annie M.G. Schmidt. They are a fine example of why so many of her verses, songs, books, plays, musicals and radio plays are both sparkling fresh and comically rebellious.

Annie was born in Zuid-Beveland in 1911. The daughter of a clergyman, she was a precocious child, and she examined the world around her with a somewhat surprised look in her eyes. She wrote her first verses of poetry when she was fourteen. After World War II, she went to work for the Amsterdam newspaper Het Parool, where she met the illustrator Fiep Westendorp. From 1952 to 1957 they worked together on a series of children's stories about a boy and a girl, Jip and Janneke [Jim and Jennifer], that were published each day in the newspaper. This marked the beginning of a lifelong collaboration that resulted in books such as Pluk van de Petteflet, Otje and Floddertje.

In the 1950s, Annie had enormous success with her fortnightly radio series De familie Doorsnee [The Average Family]. Everyone in the Netherlands listened to the series, regardless of which socio-political group they belonged to. The ups and downs of this family portrayed the contemporary life of Dutch families after the war. Annie also captured the spirit of the times in other works like her lyrics for cabaret shows and later in musicals. Her first television series "Pension Hommeles" [Bicker’s Boarding House] was screened 
and was followed by the legendary series "Ja zuster, nee zuster" [Yes, sister, No, sister], that was adapted for the big screen in 2002. Annie M.G. Schmidt's rebellious texts made her one of the most influential, and at the same time most gentle critics of the respectable, bourgeois and pillarised Netherlands.

Through her work, Annie M.G. Schmidt inspired many children and adults. Millions of copies of Jip en Janneke alone have been sold and her writing has been translated into numerous languages. Her publisher referred to her as "the true Queen of the Netherlands". When he asked her to hold a book-signing session at the Uitmarkt in Amsterdam, the organisers asked him to never do it again: the narrow lanes and alleys of Amsterdam could not cope with the crowds and congestion. The secret of her success? "I have always been eight years old. And I actually write for myself. I think that is the point. I am eight."
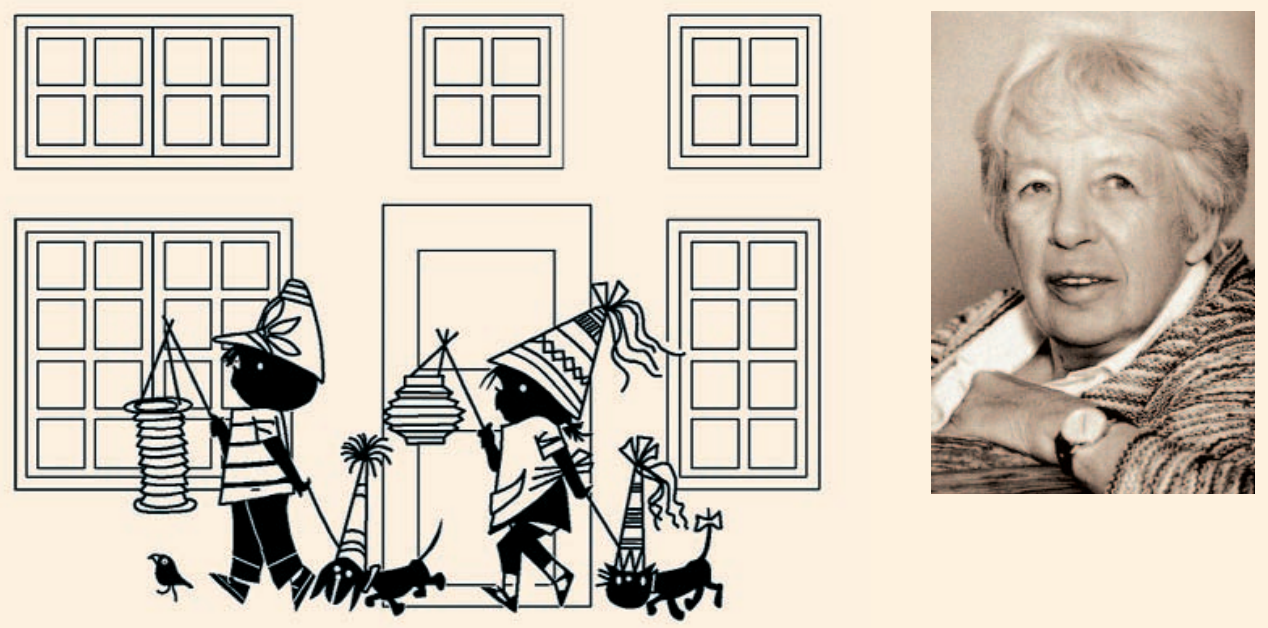

\section{References}

Primary education sector

Children's and young people's literature (by other authors too)

The language of Annie Schmidt (note, for example, the rhymes!)

From Annie's texts to illustrations, music, musicals and films

\section{Secondary education sector}

Cabaret in the Netherlands

"Nozems", "Provos" and the anti-authoritarian 1960 s Commercial business and young people

(Annie merchandising)

Past and Present

What do parents and grand-parents remember about Annie Schmidt?

In the Treasure chest

Pluk van de Petteflet
Places to Go

The Hague: Literary Museum (with a large children's section!)

Local library

\section{Books for young people}

The works of Annie M.G. Schmidt

\section{Background literature}

Annie M.G. Schmidt, Wat ik nog weet. Amsterdam 1992 Annejet van der Zijl, Anna, Amsterdam, 2003

Harry Bekkering et al. (ed.), De hele Bibelebontse berg, Amsterdam 1990 (history of Dutch children's literature)

\section{Websites}

www.annie-mg.com 


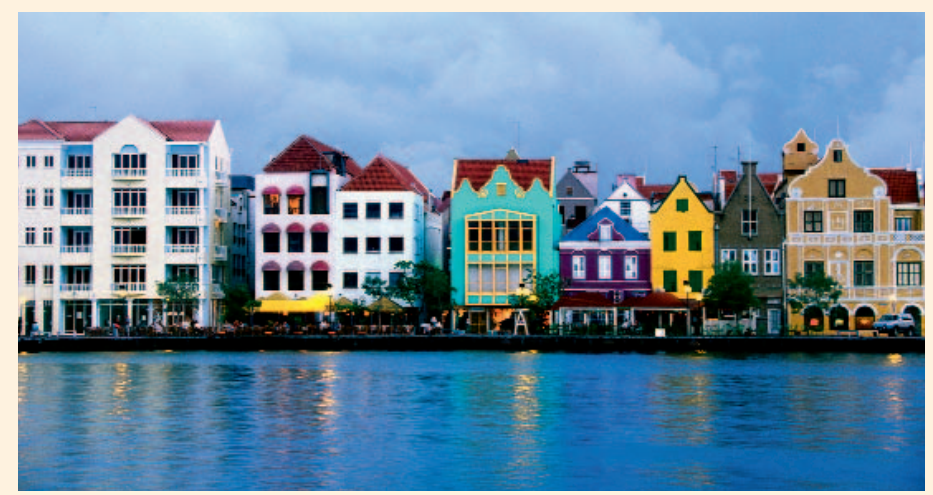

\section{5 - the present Surinam and the Netherlands Antilles}

\section{Decolonisation in the West}

The colourful architecture of Willemstad, the capital of Curaçao, bears witness to the history of this port and trade centre since 1635. Curaçao is one of the six Antillian islands that form part of the Kingdom of the Netherlands, together with Aruba, Bonaire, Saba, St. Martin and St. Eustatius. Up until 1975, Surinam was also included.

The relationships between the Netherlands and its colonies in the "West" changed drastically in the second half of the twentieth century. During World War II, Surinam and the Netherlands Antilles remained free. They provided military support to allied operations and supplied raw materials needed for the war industry, like bauxite and petroleum. After the war, the so-called overseas territories were granted regional autonomy and the right to vote. This new relationship was set down in the Charter for the Kingdom of the Netherlands (Statuut voor het Koninkrijk der Nederlanden) enacted in 1954, a type of constitution for a transatlantic kingdom with autonomous overseas territories.

In the early 1970s, many African and Asian countries had already been decolonised and in Surinam too the movement for independence began to gather momentum. The Netherlands, under the leadership of Labour Prime Minister Joop den Uyl, immediately supported this movement. Within two years, together with Henck Arron (Prime Minister of the ruling coalition party in Surinam), Den Uyl had drawn up an arrangement for arriving at independence. After weathering heavy opposition led by Jagernath Lachmon, finally, on 25 November 1975 , the arrangement resulted in the unanimous acceptance of independence. The Netherlands agreed to continue to support Surinam with development funding for a long period. These payments were suspended for a few years following the 1982 "December Murders".

In 1975, the tensions between the different ethnic groups in the run-up to independence, uncertainty about the future and the choice each inhabitant had to make between either Surinamese or Dutch nationality, led to the departure from Surinam of over 130,000 Surinamese for the Netherlands. The Charter of 1954 
continued to govern the relationship between the Netherlands and the Antilles. Within this framework, in 1986 Aruba was granted Status Aparte (separate status) and since 1996 it has been a nation within the Kingdom. Since 2005, discussions have been held with the other islands about revising their relationships.

In many ways, through their long common history, family ties and the Dutch language, the Netherlands has strong trans-national links with the multicultural Caribbean societies of Surinam, the Netherlands Antilles and Aruba. Many languages are spoken in those regions, but they all have the Dutch language in common. In 2005 Surinam became a member of the Nederlandse Taalunie [Dutch Language Union], alongside the Netherlands and Belgium/Flanders.

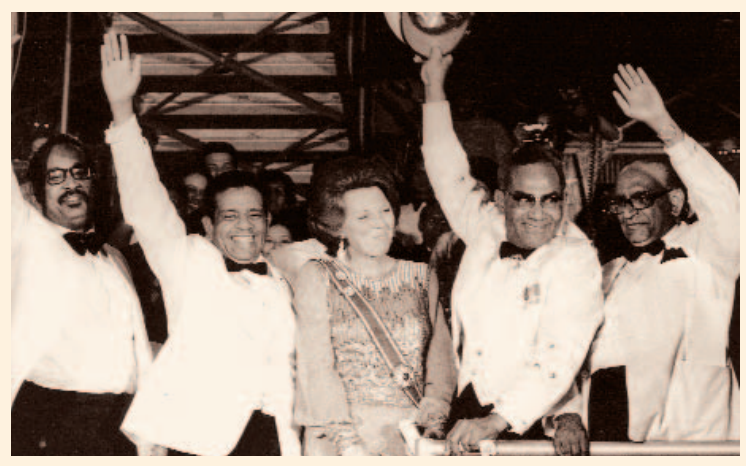

\section{Sub-topics}

\section{Primary education sector}

Exploring the Caribbean: islands, capital cities, flags

The languages of Surinam and the Antilles;

multilingualism

The cultures of Surinam and the Antilles

\section{Secondary education sector}

citizenship and nationality

The history of relations between the Netherlands and the Antilles

The role of the Dutch language outside the Netherlands (also in South Africa)

The Caribbean in the international power game

(including the problem of drug trafficking)

Willemstad and Paramaribo as world heritage sites

\section{Past and Present}

Development cooperation and former colonial relations Dutch citizenship and the subjects of the Kingdom Roots: the relationship of immigrants with the countries of origin of their forefathers (for example, India, West Africa, Indonesia, and the Caribbean)

\section{References}

\section{Places to Go}

The Hague: Sarnamihuis Amsterdam: Imagine IC Kwaku Summer Festival Antillean carnival in Rotterdam

\section{Books for young people} Henk Barnard, Kon hesi baka/Kom gauw terug Joke van Leeuwen, Sontjeland (6+) Vivian den Hollander, Spekkie en Sproet en het verdwenen beeld $(6+)$

Diana Lebacs, Caimins geheim $(9+)$ Lineke Dijkzeul, Eiland in de wind $(12+)$

\section{Background literature}

Gert Oostindie, Het paradijs overzee: De Nederlandse Caraïben en Nederland. Amsterdam 1997

A. Snijders, Landenreeks Suriname, Amsterdam 2003

\section{Websites}

geschiedenis.vpro.nl/dossiers

www.antillenhuis.nl

In the Treasure chest

Surinamese flag or clothing

Caribbean music 


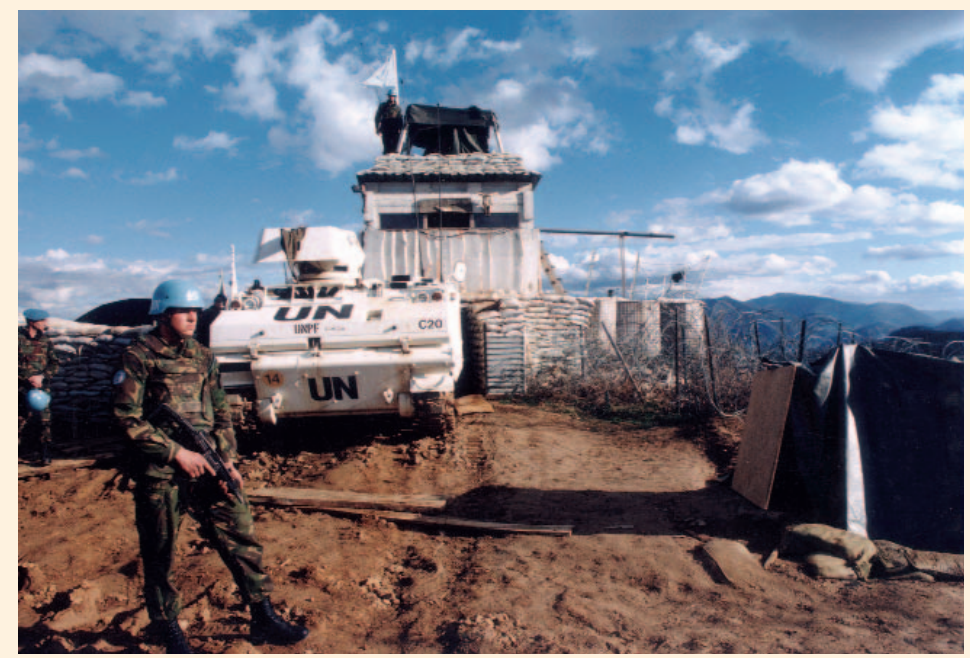

1995

\section{Srebrenica}

\section{The dilemmas of peacekeeping}

On 9 July 1995, the Bosnian Serb troops of General Mladic moved towards the Dutchbat III protected enclave of Srebrenica. Without too much resistance the attacking troops took control of this safehaven for Muslims. The Serbs had the Muslims removed in buses, after first separating the men from the women and children with assistance from the Dutch forces. A short time later, the Serbs executed most of the men (at least 7000). The Dutch soldiers, some of whom suspected what was to come but none of whom witnessed the executions, were given safe passage to Zagreb, where they were welcomed by Prime Minister Kok and Crown Prince Willem-Alexander.

When news of the massacre that had taken place "under the very eyes of Dutchbat" reached the Netherlands, the question was raised as to whether the Dutch soldiers should have protected the enclave against the Bosnian Serb troops ands so avoided the slaughter. Initially, attention was largely focused on the troops, but it soon became clear that responsibility could not be laid at their feet. Their mandate prohibited them from participating in the war. In September 1996, the Netherlands Institute for War Documentation (NIOD) was commissioned by the government to investigate the exact circumstances of the incident. When the NIOD report was published in 2002, Prime Minister Kok accepted political responsibility for the massacre in Srebrenica and resigned.

Right from the outset, Dutch soldiers have participated in UN peacekeeping missions whereby, on behalf of the United Nations, troops supervise compliance with peace treaties and ceasefires in various troubled areas around the globe. The first mission was in 1948, in Israel. A recurring problem during these missions is the instruction on the use of force. 
What are the peacekeepers allowed to do, and what is prohibited in these trouble spots? The Dutch Lower House has the ultimate say in instructing Dutch troops. The House has to endorse the agreements made between the government and the UN regarding the degree to which the troops are armed and the type of force they are permitted to use. This means that the balance between the duties of Dutch troops and the dangers they consequently run is ultimately struck in the Dutch Lower House. After the massacre at
Srebrenica, it was once again set down that the House must be kept as well informed as possible in this regard.

The aftershocks of Srebrenica were felt deeply in the Netherlands. It led to increased hesitation and more caution when deploying Dutch troops abroad. However, the incident did not result in the Netherlands sitting on the fence and rejecting international requests for military support, because the Netherlands desires to continue to play a role in international politics and peacekeeping.

N.B. The canon committee hesitated before including this window. Not so much because the underlying story is so complex, or unflattering, to put it mildly, to the Netherlands. We have faith in the capacity of primary school teachers to explain this to their pupils, and a canon has to pay its dues to the blacker moments of history too. It is, however, the case that thanks to the internet, the most horrific images of the drama in Srebrenica are only a mouse-click away. Although the truth is undoubtedly served by this, the committee would like to warn teachers and other staff about the attendant risks.

\section{Sub-topics}

\section{Primary education sector}

The modern-day life of a soldier in the Dutch armed forces

The collapse of the former Yugoslavia

The work of the international tribunal for the former Yugoslavia in The Hague

\section{Secondary education sector}

The end of the cold War and the break up of the former Yugoslavia

The ethnic situation in the Balkans

The changing role of the Dutch armed forces since the end of the cold War

The United States and the UN

The Netherlands Institute for War Documentation (NIOD) investigation and its political consequences

Past and Present

Why do Dutch troops participate in UN peacekeeping actions?

Which is better, a professional army or an army with conscripts?

In the Treasure chest

A blue UN helmet

\section{References}

Places to Go

Delft: The Army Museum

Books for young people

Jan Simoen, Met mij gaat alles goed / En met Anna? $\left(14^{+}\right)$

\section{Background literature}

Bob de Graaf, 'De val van Srebrenica (1995)', in Els Kloek (ed.), Verzameld verleden: Veertig gedenkwaardige momenten en figuren uit de vaderlandse geschiedenis. (Verloren Verleden 24). Hilversum 2004

Emir Suljagic, Briefkaarten uit het graf, 2006.

Verhalen van Veteranen: Ingezet in dienst van de Vrede. Nederlandse veteranendag als onderwijsthema voor 10- tot 15-jarigen, Enschede 2005

\section{Websites}

www.un.org/peace 


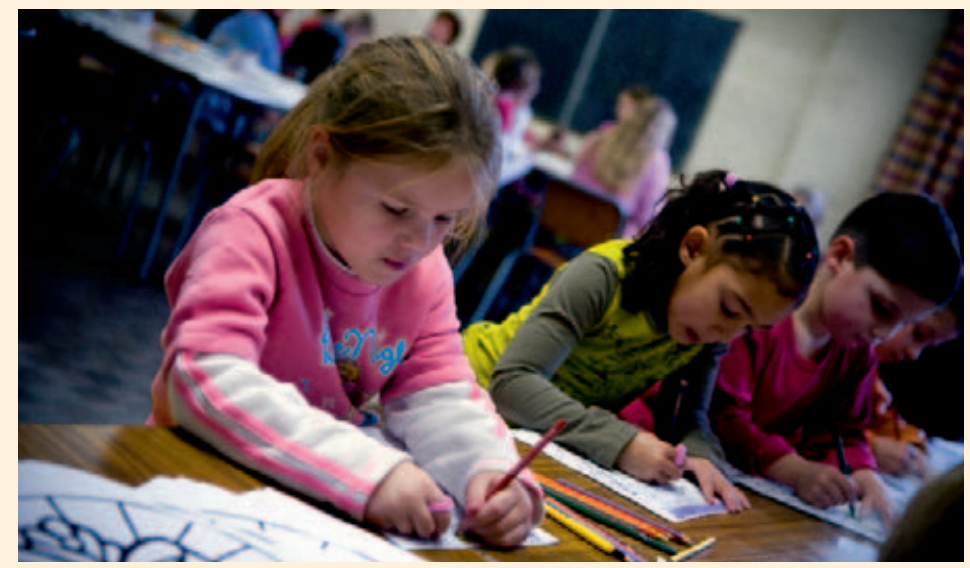

\section{5 - the present Diversity in the Netherlands The multicultural society}

On 1 January 20oo, the twentieth century passed into history and the twenty-first century began. While over five million people lived in the Netherlands in 1900, on New Year's Day 2000 this number had grown to $15,864,000$ according to figures from Statistics Netherlands. Some 1,598,200 of these were children attending primary school.

In the Netherlands, there are many types of primary schools, due among other things, to differences in religion and ideology. In addition to public schools, there are, for example, Protestant, Roman Catholic, Jewish, Islamic, Hindu, Humanist and Anthroposophist schools. In principle, the curriculum is equivalent at all of these schools. However, the lessons concerned with religion and ideology are different. Because religion can also have an effect on clothing and behaviour, on rituals and religious holidays, schools can also differ from one another in these respects. Parents choose the schools for their children for their own reasons. Pupils themselves know exactly which school they attend.

Diversity in education, on the grounds of ideology or teaching methods, has existed throughout the twentieth century. Freedom of education is set down in Article 23 of the Dutch Constitution. The decision to regard privately-run schools as equal to public schools was opposed in what came to be known as the school funding controversy. This controversy had long been settled and, as a result of the secularisation, was all but forgotten, when, in 1988 and 1989, the first Hindu and Islamic primary schools were set up.

This founding of new schools arose from changes in the composition of the Dutch population. After 1945, the Netherlands had been an emigration country with its people leaving for Australia, Canada, the United States and South Africa, while its immigrants came largely from the former Dutch East Indies. From the beginning of the 1960s, an 
active immigration policy resulted in the arrival of immigrant workers from countries like Italy, Spain, the former Yugoslavia, Turkey and Morocco, to fill jobs in Dutch industry. They brought their families with them. The Netherlands, like many other European countries, also offered asylum to political refugees and opened its borders within Europe.

In this way, the diversity of Dutch society increased rapidly in a short space of time. As recently as 1955, for example, the first mosque in the Netherlands was established in The Hague. By 2000, Islam in the Netherlands, just like Christianity, had many different branches and the

\section{Sub-topics}

\section{Primary education sector}

A few basic terms regarding various religions; comparison of religions

Immigrant groups in the Netherlands and their cultures: Jewish, African, Arabic, Indonesian, Turkish, Chinese, Gypsies

The languages of these groups

\section{Secondary education sector}

Pillarisation, schoolfunding controversy and the political system of the Netherlands; Article 23 of the Constitution

The successes and problems of a multicultural society Religion as a factor in integration Immigration and the Golden Age in the Netherlands Asylum policy and integration issues

\section{Past and Present}

Immigration in the Netherlands today and in the Golden Age

The influence of ethnic groups on Dutch eating habits

\section{In the Treasure chest}

Replicas of the earliest and current Dutch passports minaret is now a well-known city image. Since the beginning of the twenty-first century, a new kind of school funding controversy has been raging, largely around new Islamic schools. This reflects the fierce political debate about the relationship between society, culture and religion that is being conducted on numerous themes: from major political issues to the problems of everyday life. Time and again the question of what "being Dutch" actually entails is raised. The current, diverse generation of young Dutch residents who are attending school now will be the ones to add substance to the answer.

\section{References}

\section{Places to Go}

Visit a church, synagogue, mosque and other religious places

Visit ethnic restaurants

Take a walk through a multicultural neighbourhood

\section{Books for young people}

Max Velthuijs, Kikker en de vreemdeling (4+)

Emma Damon, En ik, en ik, en ik, allemaal kinderen $\left(4^{+}\right)$

Emma Damon, Geloof jij wat ik geloof? (4+)

Jacques Vriens, De ontvoering van de zwarte prinses $\left(7^{+}\right)$

Anke de Vries, Kladwerk (9+)

Guus Kuijer, Polleke (11+)

Karlijn Stoffels, Marokko aan de plas (12+)

Anton van der Kolk, Het huis aan de overkant (12+)

Anne Provoost, Vollen $\left(14^{+}\right)$

Series Volksverhalen uit kleurrijk Nederland

\section{Background literature}

Jan Lucassen and Rinus Penninx, Nieuwkomers, nakomelingen, Nederlanders: immigranten in Nederland 1550-1993, Amsterdam 1994

\section{Websites}

www.forum.nl

www.iot.nl

www.maghreb.nl

www.anno.nl/anno/anno/io02796.html

www.beleven.org (folk tales from across the globe) 


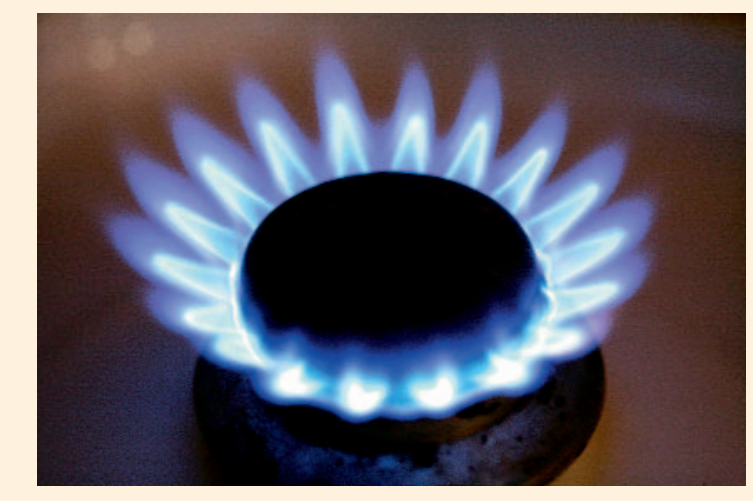

\section{$1959-2030 ?$ \\ The natural gas deposit \\ A finite treasure}

It has been called the raft on which the Dutch economy and prosperity floats: the enormous gas field that was discovered in 1959 near Slochteren in the province of Groningen. It is estimated that more than 300 billion cubic metres of gas lie in the ground here: the second-largest deposit of gas known at the time. It is now known that the field contains 3000 billion cubic metres of gas. Thanks to this discovery, the Netherlands has gradually switched over to gas completely. Almost every household uses natural gas, and over ten thousand glasshouses and some five thousand businesses are connected to the natural gas network.

The so-called "gas pocket" is not actually a pocket. The gas is trapped in porous rock underground. It is sealed from above by a layer of impermeable rock (otherwise the gas would have escaped into the atmosphere long ago). As the gas is extracted, the rock simply stays where it is. And yet, during large-scale gas extraction, slight earth tremors may occur caused by underground subsidence, which can lead to cracks in walls or roads.
For the Dutch government, natural gas is a source of revenue. The state has a profit share. The price of natural gas is linked to the price of oil, and as the oil price continues to rise, so to do the revenues from natural gas. The question is: how long can the Netherlands continue to profit from this natural source of energy? According to the Nederlandse Aardolie Maatschappij (Netherlands Petroleum Company; NAM), that deals with extracting the gas, the reserves are sufficient for at least a further twenty-five years of high-level production. However, the NAM believes that it will gradually become more difficult to meet all obligations. Dutch and foreign customers would have to be served, in peak-demand periods as well, while the pressure in the Slochteren field is already reducing significantly. The technical problems involved in continuing to extract large volumes of gas from the field will become increasingly greater.

It is for good reason that the NAM would like to begin operations in new fields, including under the Wadden Sea, something to which some environmental 
organisations are violently opposed. Their objections are not aimed at the use of natural gas - it is a clean fuel - but rather at the disturbance of the tranquillity of the Wadden Sea, the most important nature reserve in the Netherlands - and at skyline pollution, and, in particular, subsidence in the area. The major lobbyist for the area, the Wadden Society, has agreed to operations being implemented with the proviso that this takes place under stringent conditions.

Future generations will be faced with difficult political choices. Can the Nether-

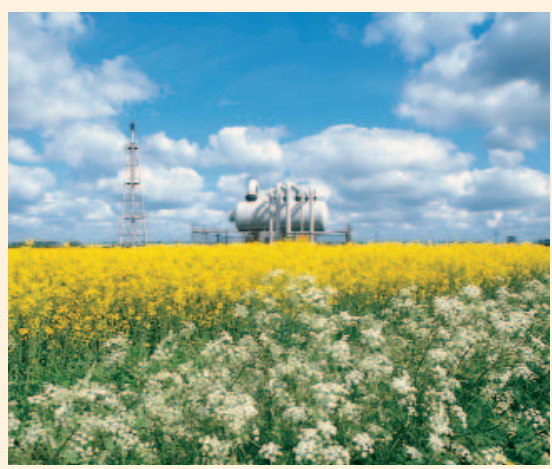

\section{Sub-topics}

\section{Primary education sector}

Natural gas and the Wadden Sea

Where do we get the energy from?

Limburg mines (and longer ago: Drenthe peat)

\section{Secondary education sector}

The geology of the Netherlands

The Dutch economy with and without gas revenues

The use of raw materials and energy sources in

human society: the historical perspective

Opec and the Arab world (including the 1973 oil crisis)

Energy and the natural sciences; bio energy

\section{Past and Present}

Tensions between the economy and nature management The major oil companies and their role in the

Netherlands and the world

Scientific research on energy

\section{In the Treasure chest}

NAM information pack lands manage without revenues from natural gas? Can the country, if the worst comes to the worst, convert to alternative energy sources? Should the Netherlands import more foreign natural gas and store it in its gas fields? And as far as the Wadden Sea is concerned: does nature conservation deserve a higher priority than economic gain, are gas revenues more important than the environment or can the quality of the environment and gas extraction be combined in an acceptable manner?

\section{References}

Places to Go

ECN, Petten

\section{Books for young people}

Clive Gifford, Duurzame ontwikkeling (series: Feiten over...) $(12+$ info)

\section{Background literature}

Herman de Jong, "Slochteren" in Wim van den Doel (ed.), Plaatsen van herinnering. Nederland in de twintigste eeuw, Amsterdam 2005

\section{Websites}

www.ecn.nl

www.nam.nl 


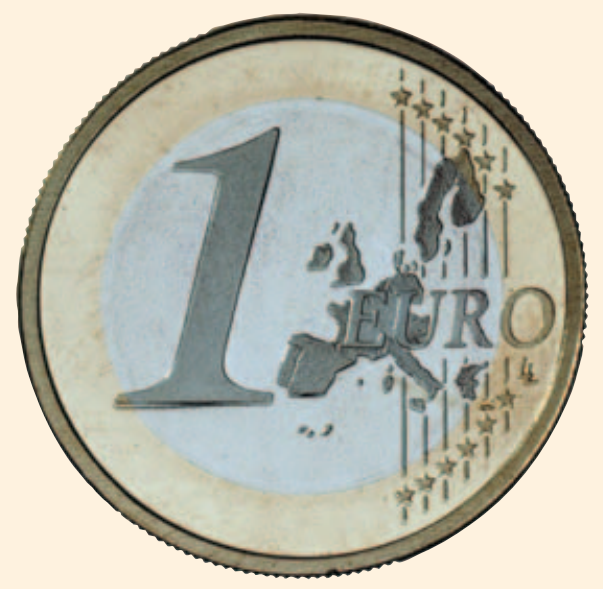

\section{5 - the present \\ Europe}

\section{The Dutch and Europeans}

The Netherlands does not exist in isolation. It is closely tied to its neighbouring countries and together they form Europe. After World War II, the heads of state of a number of western European countries realised that the future of Europe lay in cooperation, to prevent another war breaking out. It started with cooperation in the area of strategic resources. Around 1950, these resources were coal and steel. At the time, coal was the major energy source, and steel was needed in large amounts to reconstruct the infrastructure of western Europe. Six European countries signed the Treaty of Paris in 1951, and by doing so established the European Coal and Steel Community (ECSC). This treaty allowed for, among other things, free trade in these resources between the six participating nations: the Netherlands, Belgium, Luxembourg, France, Germany and Italy.

In 1957, the six nations took the next step by signing the Treaty of Rome. This made the European Economic Community
(EEC) a reality: a customs union of the six member countries that guaranteed free trade in all products. The EEC quickly launched a common agricultural policy aimed at safeguarding the provision of food and improving the incomes of farmers. The Treaty also established the European Atomic Energy Community (better known as Euratom), a third European community, focused on the exploration and development of nuclear energy for peaceful purposes. Later, the three Communities were merged into a single European Community; today, it is referred to as the European Union (EU).

This European cooperation was a success in many ways. Numerous other European nations wished to join. The first new members were the United Kingdom, Denmark and Ireland (1973), followed later by southern European enlargement with the addition of Greece (1981) and Spain and Portugal (1986). In 1995, Austria, Finland and Sweden joined, bringing the number of member states 
to fifteen. The biggest enlargement took place in 2004 when eight countries from the former Eastern Bloc acceded to the European Union along with Malta and Cyprus. In 2007, the EU member states number twenty-five and further enlargement is around the corner.

A European Union comprising ever more countries is also an EU of more and more votes, interests and cultures. This makes it increasingly difficult to agree on the future aims of the EU and on the priorities for European cooperation as shown by the Dutch rejection of the proposals for a European Constitution. For the Netherlands, a future without Europe is virtually unimaginable. The vast majority of the nation's trade takes place within Europe. The various economies of the EU are strongly interwoven and the freedom of movement of workers regularly reminds the Dutch (and others) that we are all part of Europe and we are all Europeans.

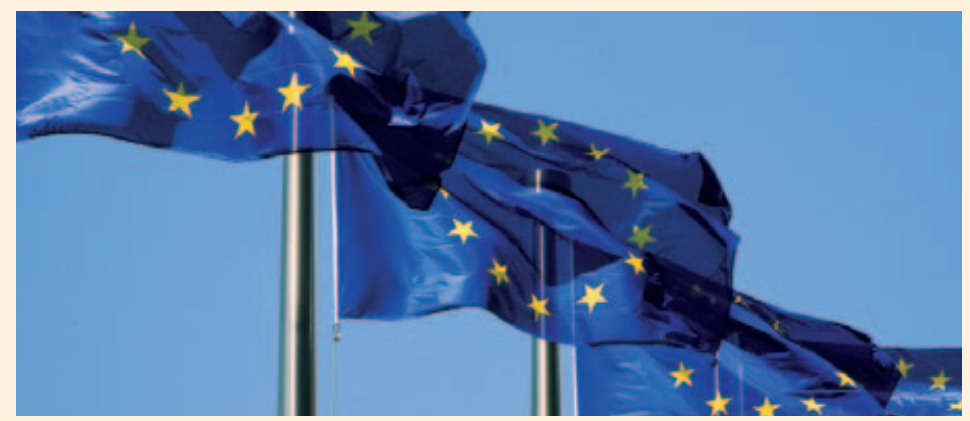

\section{Sub-topics}

\section{Primary education sector}

The euro and agriculture in Europe

Getting to know other European countries, languages and cultures

The fall of the Berlin Wall: Europe opens up to the Eastern Bloc

\section{Secondary education sector}

Economics: free trade zone, internal markets, market integration

Turkey and Europe

The geography of Europe and of European cooperation

The history of European unification (for example, the position of the United Kingdom)

A European Constitution?

\section{Past and Present}

The Europe of Charlemagne, Charles V, Napoleon and today

In the Treasure chest

The old Dutch guilder

\section{References}

\section{Places to Go}

Take a holiday in Europe

Books for young people Amanda Aizpuriete, Op bezoek in Letland $\left(9^{+}\right)$ Jan Willem Bultje, Op bezoek in België (9+) Jan Willem Bultje, op bezoek in Litouwen $\left(9^{+}\right)$ Jan Willem Bultje, Op bezoek in Nederland $\left(9^{+}\right)$ Jan Willem Bultje, Op bezoek in Tsjechië $(9+)$

E. Hiiepuu, op bezoek in Estland $\left(9^{+}\right)$

J. Kadziolka, Op bezoek in Polen ( $\left.9^{+}\right)$

D. Kollar, Op bezoek in Slowakije $\left(9^{+}\right)$

S. Lang, Op bezoek in Hongarije $(9+)$

Danica Veceric, Op bezoek in Slovenië $(9+)$

\section{Background literature}

Wim van den Doel, "Maastricht: Plein 1992. Het Verdrag van Maastricht" in: Plaatsen van herinnering: Nederland in de twintigste eeuw, Amsterdam, 2006

\section{Websites}

www.europa.eu.int www.go-europe.nl www.europasite.net burgerschap.kennisnet.nl/ineuropa 


\section{Main lines of the canon}

\section{Introductory explanation: characteristics of the main lines}

- It is important that certain terms like "the Netherlands", "Dutch culture" and "Dutch history" are used with caution. After all, up until the nineteenth century the term "the Netherlands" is an anachronism and the adjective "Dutch" remains problematic in early history. When a text mentions the history of Dutch language and culture, and Dutch territory and the Dutch state, we actually mean "relevant to this region", without the suggestion that this region in that time already presented a cultural, political or linguistic unity. We have treated these matters as historical phenomena.

- In the texts, Dutch history and culture are not treated as isolated components but rather they are described within the context of developments in Europe and the rest of the world.

- The structure of the main lines is roughly chronological, although it should be pointed out that certain aspects (for example, the struggle against the water or Christian culture) cannot be restricted to one single period.

- The main lines provide orientation in time and place: they sketch a general picture of what the previous generations that inhabited this region would have experienced. 


\section{Main lines of the canon of Dutch history and culture}

\section{Introduction}

These fourteen "main lines of the canon" are meant to serve as background texts to the fifty windows. They are the red threads running through the history of the Netherlands that indicate the cross-links between the separate windows, thereby helping to create cohesion in the topics, objects, persons and themes featured on the chart.

\section{The Low Countries by the sea}

The modern-day Netherlands was largely "created” by human hands: dyked-in, reclaimed and developed. Adapting to and struggling against water is a red thread in the history of this region.

$\rightarrow$ The Beemster polder • The great flood

\section{On the periphery of Europe}

The region that is today known as the Netherlands is a river delta on the periphery of the European continent. This geographic position has determined the history of the region throughout the centuries. In $4500 \mathrm{BC}$, an agrarian society began to develop here, and from the beginning of the Christian era the region formed one of the frontiers of the Roman Empire. In later centuries, the region became part of other large empires. It was only from about 1590 that the first contours of the modern-day Netherlands began to be mapped. However, the borders would often be changed dramatically.

$\rightarrow$ The Roman Limes • Charlemagne • Charles V

\section{A converted country}

Little is known about the religion of the earliest inhabitants of the region, but thanks to Tacitus (among others) we do know something about the gods that the people here honoured. The people of the low countries converted to Christianity from about 600-700 AD. Monasteries became centres of culture. In the sixteenth and seventeenth centuries, wars were waged in the name of the true doctrine. Today, Christianity still remains an important feature of Dutch culture.

$\rightarrow$ Megalithic tombs • The Roman Limes • Willibrord • Erasmus • The Beeldenstorm • The Statenbijbel 


\section{A Dutch language}

The earliest extant words written in Dutch date from circa 110o. They were written by a Flemish monk. Printed material in the "mother tongue" only became available in the sixteenth century. Many people continued to speak and write in Latin (scientists) and in French (the elite). Regions had their own dialects. And yet the Netherlands has a long history of literature in its own language. The borders of language do not run parallel to political borders.

\section{$\rightarrow$ Hebban olla vogala • The printing press • The Statenbijbel •} Max Havelaar • Annie M.G. Schmidt

\section{An urbanised country and a trading hub at the mouth of} the Rhine, Schelde and Maas rivers

From circa 110o, urbanisation began to take place in the region and trading centres were established. The centre of gravity initially lay in the south (Flanders and Brabant), but by circa 1500 the north (province of Holland) was a strong centre of trade. From circa 1600, the provinces of Holland and Zeeland were important hubs for trade in Europe. The modern-day Netherlands continues to fulfil this function.

\section{$\rightarrow$ The Hanseatic League • The canal ring • The port of Rotterdam}

\section{The Republic of the Seven United Netherlands: founded on rebellion}

Towns, with their citizens, have different interests than the nobility.

The first signs of a clash of these interests could be seen early. In the late Middle Ages, the Burgundian rulers tried to bring the Low Countries under one administration, but this policy met with resistance from both towndwellers and the nobility. In the sixteenth century, this resistance blended with the call for Reformation. War broke out and the nobility became "gueux'. William of Orange rose to become the leader of the Rebellion and for this reason is known as the "father of the fatherland". The unique political structure known as the "Republic" developed after his violent death in 1584 . Features of the Republic: the administrative power of regents; weak central authority; religious tolerance.

$\rightarrow$ Floris $\mathbf{V} \bullet$ Charles $\mathbf{V} \bullet$ The Beeldenstorm • William of Orange • The Republic • Spinoza • The canal ring 


\section{The blossoming of the Golden Age}

The Republic of the Seven United Netherlands was a superpower in Europe in the seventeenth century: economically, politically and culturally. The period was short but intense. Immigrants (Jews, Flemings, Huguenots) played an important role in this blossoming.

In the cultural domain, the scope and quality of seventeenth-century painting was particularly remarkable. Economically, it was shipping, the staple market, the highly-developed land cultivation and industry. Politically, the Republic had a unique form of government on a continent where monarchies were the rule. The disaster year of 1672 signalled the beginning of the end for this period of previously unknown blossoming. Thereafter, the Republic was a humble player on the European stage, dependent on the European powers for room to manoeuvre. In economic and cultural terms, the Republic was also less of a European player from the end of the seventeenth century.

$\rightarrow$ Rembrandt • Michiel de Ruyter • Spinoza • Country mansions

\section{Business sense and colonial power}

Dutch ships took to the seas from about 1600. Europe was the world's centre of trade, but business was conducted in Asia, Africa and America as well. Colonies were established in Asia and America. The Dutch also traded in slaves on all three continents. In the nineteenth century, the centralisation of the Dutch administration of the colonies led to lengthy wars. To this day, the Netherlands still maintains strong ties with Indonesia, Surinam and the Antilles.

$\rightarrow$ The VOC • Slavery • Max Havelaar • Indonesia • Surinam and the Antilles • Diversity in the Netherlands

\section{Nation-state, constitutional monarchy}

In the second half of the eighteenth century, due to the influence of the Enlightenment, among other things, the need arose among a broad range of people to acquire and disseminate knowledge. New ideas about the organisation of the state and society were discussed. The patriot movement's attempts to limit the power of the Stadholders (governors) and to give the people a greater voice were initially unsuccessful. 
The modern-day Dutch state was formed between 1795 and 1848. The foundations of the nation-state were laid in the French period (1795-1813). After the defeat of Napoleon, William I, the son of the last Stadholder (governor) became king of a united kingdom. This "restoration" of the Netherlands did not last long, because Brussels joined in the rebellions of the year 1830 . In 1848 , the foundations for a constitutional monarchy (as the Netherlands still is today) were laid with the drafting of the Constitution by Thorbecke. The kingdom became minor power that cherishes its neutrality.

$\rightarrow$ Country mansions • Eise Eisinga • The patriots • Napoleon Bonaparte • King William I • The Constitution

\section{The rise of modern society}

From circa 1870, Amsterdam, Rotterdam, The Hague and Utrecht began to grow into cities. Industrialisation reached the region relatively late. The laying of the first railways began somewhat earlier. Distances became smaller: the integration of the Netherlands had begun.

The call for equality under the law became stronger. "Common" citizens demanded their say in society and politics. This resulted in universal suffrage being granted to men and women in 1917 and 1919 respectively. "Modern" artists of the time no longer regarded themselves as the keepers of established artistic traditions and reveal themselves as artistic innovators. In literature this goal is reflected in the "Movement of the Eighties", in painting, in Impressionism and Post-impressionism and in the applied art of the Art Nouveau and Modernism movements.

$\rightarrow$ The first railway • Opposition to child labour • Vincent van Gogh • Aletta Jacobs • World War I • De Stijl

\section{The Netherlands in a time of World War 1914-1945}

As a small country, the Netherlands tried to avoid involvement in large conflicts in Europe. It succeeded during World War I, but at its end, the Netherlands was dragged into a world crisis. The blackest moments of the German occupation were the bombing of Rotterdam, the deportation and murder of the Jewish population and the winter of starvation. In Asia, the war began in 1942, but after the liberation of 1945 a new war began that lasted until 1949. World War II is referred to as "the past that refuses to become history".

$\rightarrow$ World War I • De Stijl • The crisis years • World War II • Anne Frank • Indonesia 


\section{The welfare state, democratisation and secularisation}

Reconstruction began immediately after the end of World War II. After those years of deprivation and hard work, the 1950s heralded in a period of great change in the lifestyle of the Dutch population. The welfare state and an affluent society ensured a radical rise in the standard of living. In addition, people were breaking their ties with their church, socio-political group and family. This change was marked in particular by less hierarchical relationships between parents and children, the rise of new male and female role patterns and increasingly open views on sexuality. In terms of politics, this was combined with a strong movement towards democratisation: the authority of established, elite groups was called into question.

$\rightarrow$ Willem Drees • The great flood • Television • The port of Rotterdam • Annie M.G. Schmidt • The natural gas deposit

\section{The diversification of the Netherlands}

After World War II, the Netherlands became embroiled in a colonial war with the Indonesian independence movement. During and after this war, many Dutch, Indo-Europeans, and Moluccans left for the Netherlands.

Other immigration waves followed: in the 1960s, workers from Mediterranean countries arrived, at the time of the decolonisation of Surinam (1975) people arrived from the former colony and later from the Netherlands Antilles, as well as numerous other regions. Dutch society changed with this increasing immigration. Inevitably, tensions arose between the established inhabitants and the new arrivals.

$\rightarrow$ Indonesia • Surinam and the Antilles • Diversity in the Netherlands

\section{The Netherlands in Europe}

After World War II made way for the Cold War, the Netherlands became an advocate of Atlantic and European cooperation. Once the Cold War had ended, European cooperation rapidly gained momentum. In this phase, the Netherlands was also active in UN peacekeeping missions. 


\section{Primary education sector and lower secondary education}

The table below gives a summary of the possibilities for differentiating the content of the wall chart with fifty topics and the main lines for the primary education sector and the lower secondary education sector respectively.

\section{Primary education}

Dutch history and culture form the core of the course material.

\section{Lower secondary education}

European history and culture together form the starting point for the course material. Dutch history and culture are discussed as a component of this complex.

The "story of the Netherlands" is part of and connected to other "stories". Comparisons are therefore possible, for example, comparing the Republic with French absolutism, or Dutch democracy in the 1930 with German Nazism.

Alongside the storyline aspect, more attention is paid to the relationships between the themes and to long-term developments.

The emphasis is still on the acquisition of orientation knowledge, but on a higher, more abstract level than at primary schools. This means that it is possible to pay more attention to, for example, causeand-effect relationships and historical empathy. 


\section{Acknowledgements}

\section{Megalithic tombs}

Left: Megalithic tomb, ANP/Koen Suyk. Right (from left to right): Funnel beaker, Rijksmuseum van Oudheiden; Megalithic tomb of Loon, archives of Leendert P. Louwe Kooymans.

\section{The Roman Limes}

Left: Milestone, Archeologische Dienst, The Hague. Right: Tabula Peutingeriana, Conradi Milleri, Bibliotheca Augustina.

\section{Willibrord}

Left: Willibrord, Bibliothèque Nationale de France/Latin 10510.

Right (from left to right): Digital visualisation of the Chapel of the Holy Cross and the St. Servator church, DeroDezD/Rijntjes/Stöver.

\section{Charlemagne}

Left: Bust of Charlemagne, Domkapitel Aachen/ Ann Münchow.

Right (from left to right): Portrait of Charlemagne, Albrecht Dürer, Germanisches Nationalmuseum, Nuremberg; signature of Charlemagne.

\section{Hebban olla vogala}

Left: Latin handwriting from the abbey of Rochester, Bodleian Library, 0xford/MS. Bodl. 340, fol. $169 \mathrm{v}$.

Right (from left to right): Scriptorium initial from the Rooklooster with writing monk, Hs. Brussel, Koninklijke Bibliotheek, 213, fol. 2r.; Parchment seller, Hs. Kopenhagen, Kongelige Bibliotek, GKS F4, bd. 1, f. 183r.

\section{Floris V}

Left: Ridderzaal, ANP/Cees van Leeuwen.

Right (from left to right): Engraving of Floris $V$, Principes Hollandie et Zelandie, Domi Frisiae, Michiel Vosmeer; Muiden Castle, Rijksmuseum Muiderslot.

\section{The Hanseatic League}

Left: View of Zwolle, Stedelijk Museum Zwolle. Right (from left to right): Carta marina of the Baltic Sea, Olaus Magnus, Royal Library, Stockholm.

\section{The printing press}

Left: Type letter, Museum Plantin-Moretus, Antwerpen.

Right: Interior of a 16th century printing shop, Bibliotheque Nationale de France, Parijs/Lauros/ Giraudon/The Bridgeman Art Library/XIR159029.

\section{Erasmus}

Left: Portrait of Erasmus, Quinten Metsijs, The Royal Collection of H.M. The Queen, Buckingham Palace.

Right (from left to right): Illustration in the margin of Praise of Folly, Holbein the Younger, Kupferstichkabinett, Öffentliche Kunstsammlung, Basel; Page from Praise of Folly, Collectie Bibliotheek Rotterdam.

\section{Charles V}

Left: Charles V, Titian, Alte Pinakothek, Munich/ The Bridgeman Art Library/XIR158620.

Right: Charles V on horseback, Titian, Museo del Prado, Madrid. 
The Beeldenstorm (iconoclastic outbreak) Left: Coloured engraving of the iconoclastic outbreak, Hoogenbergh, Atlas Van Stolk, Rotterdam/AVS 50439(3).

\section{William of Orange}

Left: Portrait of William of Orange, Adriaen Thomasz. Key, Collection of the Rijksmuseum Amsterdam/SK-A-3148.

\section{The Republic}

Left: Leo Belgica, Atlas Van Stolk, Rotterdam/ AVS 1248.

\section{The Dutch East India Company (Voc)}

Left: Replica of the Batovia, Batavia shipyard Nationaal Scheepshistorisch Centrum/ Jaap Roskam.

\section{The Beemster polder}

Left: Copper engraving of a map of the Beemster, Daniel van Breen, Nederlands Scheepvaartmuseum Amsterdam/Bart Lahr/S.1034(03) [map 053].

Right (from left to right): Aerial photograph of the Beemster, Pandion/Peter Bolhuis; working drawing of a typical Beemster mill, from "Groot volkomen Moolenboek", unknown.

\section{The canal ring}

Left: Herengracht, Co de Kruijf/Hollandse Hoogte. Right: Amsterdam conal, Andrew Ward/Life File, Getty Images.

\section{Hugo Grotius}

Left: The book chest of Hugo Grotius, Collection of the Rijksmuseum Amsterdam/NG-KOG-1208. Right (from left to right): Portrait of Hugo Grotius, Michiel Jansz. van Miereveld, Collection of the Rijksmuseum Amsterdam; aerial photograph of Loevestein Costle, Loevestein Castle.
The Statenbijbel (authorised version of the Bible) Left: Statenbijbel, Platvorm BV. Right (from left to right): Title page of the Statenbijbel, collection of the Catherijneconvent, Utrecht; Old woman reading from a lectionarium, Gerard Dou, Collection of the Rijksmuseum Amsterdam/SK-A-2627.

\section{Rembrandt}

Left: Het korporaalschap van kapitein Frans Banninck Cocq en luitenant Willem van Ruytenburch/The Night Wotch, Rembrandt Harmensz. van Rijn, Collection of the Rijksmuseum Amsterdam/SK-C-5.

\section{Blaeu's Atlas Major}

Left: Title page of the Atlas Mojor, Blaeu, Hollandia 1604, Universiteitsbibliotheek UvA, Bijzondere Collecties.

Right (from left to right): Frontispiece from Blaeu's Theatrum, Blaeu Sr. and Jr., 1645, unknown; Theatre of the World, or a New Atlas of Maps and Representations of All Regions, Willem and Joan Blaeu, unknown.

\section{Michiel de Ruyter}

Left: Portroit of Michiel Adriaenszoon de Ruyter, Ferdinand Bol, Collection of the Rijksmuseum Amsterdam/SK-A-44.

Right: The court martial aboard the Seven Provinces, Willem van de velde Senior, Rijksmuseum, Amsterdam/SK-A- 4289.

\section{Spinoza}

Left: Portrait of Baruch de Spinoza, Herzog August Bibliothek Wolfenbüttel/B 117. Right: Spinozohuis Rijnsburg, Vereniging Het Spinozahuis.

\section{Slavery}

Left: Narrative of a 5 years' expedition against the revolted negroes of Surinam..., J.G. Stedman, Collection of the Koninklijk Instituut voor de Tropen. 


\section{Country mansions}

Left: Goudestein, Municipality of Maarssen.

Right: Country mansion on the Vecht river,

Sijmen Hendriks/Hollandse Hoogte.

\section{Eise Eisinga}

Left: Ceiling of the plonetorium, Eise Eisinga

Planetarium, Franeker.

Right (from left to right): Interior of the planetarium, Eise Eisinga Planetarium, Franeker; Portrait of Eisinga, Willem Bartels van der Kooi,

Eise Eisinga Planetarium, Franeker.

\section{The patriots}

Left: Engroving from "De politieke kruyer", Universiteitsbibliotheek UvA, Special collections. Right: Coloured engroving entitled: "Princess Wilhelmina held coptive...", G.A. Lehman, Atlas van Stolk, Rotterdam.

\section{Napoleon Bonaparte}

Left: Etude de Tête pour un portrait de Napoléon Ier en costume de Sacre, David Jacques Louis, Photo RMN/Christian Jean/89-002118/T184. Right: Portrait of Napoleon on the Imperial Throne, Jean-Auguste-Dominique Ingres, Musée de l'Armée, Paris.

\section{King William I}

Left: William I with a map of Jova, Joseph Paelinck, Collection of the Rijksmuseum Amsterdam/SK-C-1460.

Right: Tableau of the September days in 1830, Grote Markt, Egide Charles Gustave Wappers, Musée d'Art Ancien, Brussels.

\section{The first railway}

Left: The "Arend" powered by steam, Collection of the Spoorwegmuseum.

Right: Opening of the first Amsterdam-Haarlem link, collection of the Spoorwegmuseum.

\section{The Constitution}

Left: The Constitution of 1848, Beeldbank Nationaal Archief.

Right: Portrait of Johan Rudolf Thorbecke, Johan Heinrich Neuman, Collection of the Rijksmuseum Amsterdam/ SK-A-4120.

\section{Max Havelaar}

Left: Cover of Max Havelaar, published by Pandora.

Right (from left to right): First edition of Max Hovelaar and photograph of Multatuli, Collection of the Multatuli Museum.

\section{Opposition to child labour}

Left: Sewing burlap sacks, Beeldbank Nationaal Archief/BG A23/648.

Right: Child labour in the printing industry, Beeldbank Nationaal Archief BG B15/237.

\section{Vincent van Gogh}

Left: Sunflowers, Vincent van Gogh,
S31V/1962 F458.

\section{Aletta Jacobs}

Left: Aletto as a new graduate of medicine, Bibliotheek der Rijksuniversiteit Groningen.

\section{World War I}

Left: Australian soldiers with gas masks (1917), Imperial War Museum/Captain Frank Hurley. Right (from left to right): Arrival of Belgian refugees on a horse-drawn cart from the port of Antwerp, Regionaal Historisch Centrum Bergen op Zoom; Western front, Belgion and French soldiers in a trench (1917), unknown.

\section{De Stijl}

Left: Red and blue armchair, Gerrit Rietveld, Collection of the Centraal Museum, Utrecht. Right (from left to right): Composition in Red, Blue and Yellow (1930), Piet Mondrian, Fukuoka City Bank LTD, Fukuoka, Japan; Rietveld-schröderhuis, Collection of the Centraal Museum, Utrecht.

\section{The crisis years}

Left: Who will help me along, Spaanrnestad Fotoarchief.

Right: H. Colijn during a speech (1938), ANP Historisch Archief. 


\section{World War II}

Left: Seyss-Inquart during his speech to newlysworn-in army recruits in 1943, ANP Historisch Archief/F.C. de Haan.

\section{Anne Frank}

Left: Anne Frank, AFF Basel/AFS Amsterdam.

Right: The entrance to the Achterhuis,

\section{Indonesia}

Left: Handwritten Proklamasi, Koninklijk Instituut voor de Tropen.

Right: Hatto and Sukarno on Indonesion stomps, unknown.

\section{Willem Drees}

Left: Willem Drees Sr., Internationaal Instituut voor Sociale Geschiedenis/BG B27/653.

The great flood

Left: Small boat, unknown.

Right: Dreischen, unknown; Rescue by a soldier, unknown.

\section{Television}

Left: Television, Bradley Mason.

Right: Philips brochure, Philips Company Archives.

\section{Port of Rotterdam}

Left: OOCL container ship in the port of Rotterdam, ANP/Robin Utrecht.

Right: ECT: Europe Container Terminals on the Maasvlakte, Roger Cremers/Hollandse Hoogte.

\section{Annie M.G. Schmidt}

Left: Cover of Pluk van de Petteflet, Fiep Westendorp, Em. Querido's Uitgeverij BV. Right (from left to right): Jip and Janneke, Fiep Westendorp, Illustre BV.; Photograph of Annie M.G. Schmidt, Steye Raviez/Hollandse Hoogte.

\section{Surinam and the Netherlands Antilles}

Left: Willemstad woterfront, Curacao, Brand X Pictures/Hollandse Hoogte. Right: Raising of the flog ceremony in the suriname Stadium leads to exuberant celebrations among VIPs, ANP Historisch Archief.

\section{Srebrenica}

Left: Dutchbat in Srebrenica, Ministry of Defence.

\section{Diversity in the Netherlands}

Left: Community centre children's afternoon, Chris Pennarts/Hollandse Hoogte.

\section{The natural gas deposit}

Left: Burner on a gas hob, Rob Huibers/ Hollandse Hoogte.

Right (from left to right): Flare and drum, N.A.M.; Buizen, N.A.M.

\section{Europe}

Left: Euro coin, Koninklijke Nederlandse Munt. Right: Close-up of a row of flags in front of the Berlaymont building in Brussels, Franky De Meyer. 